
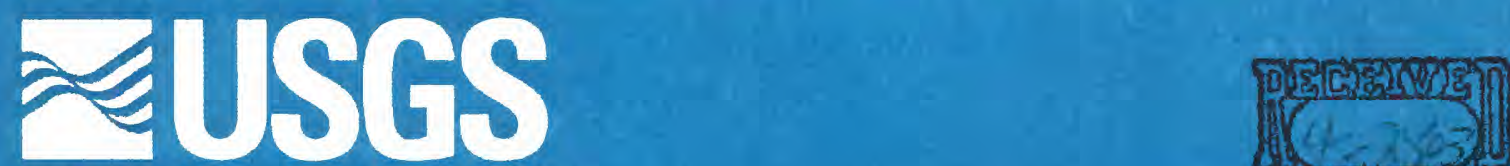

\title{
HYDROLOGIC AND SEDIMENTOLOGIC RESPONSE OF TWO BURNED WATERSHEDS IN COLORADO
}

\section{U.S. Geological Survey Water Resources Investigation Report 01-4122}

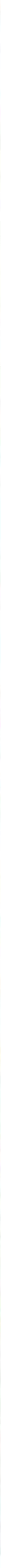




\section{HYDROLOGIC AND SEDIMENTOLOGIC RESPONSE OF TWO BURNED WATERSHEDS IN COLORADO}

by John A. Moody and Deborah A. Martin

U.S. Geological Survey

Water Resources Investigative Report 01-4122

Prepared in cooperation with the

DENVER WATER DEPARTMENT and the

U. S. FOREST SERVICE

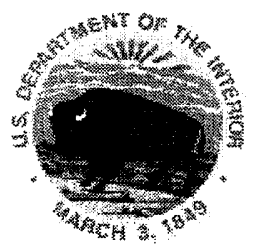

Denver, Colorado 2001 


\title{
U. S. DEPARTMENT OF THE INTERIOR
}

\author{
GALE A. NORTON, Secretary \\ U.S. GEOLOGICAL SURVEY \\ CHARLES G. GROAT, Director
}

The use of trade, product, industry, or firm names is for descriptive purposes only and does not imply endorsement by the U. S. Government

Cover Photo: Courtesy of Pat Lang and unknown photographer, Buffalo Creek, Colorado. Aerial view of the Buffalo Creek burned area looking west with Spring Creek in the foreground draining into the South Platte River.

For addition information write to:

Chief, Branch of Regional Research U.S. Geological Survey

Box 25046, MS 418

Denver Federal Center

Lakewood, CO 80225
Copies of this report can be purchased from:

U. S. Geological Survey

Earth Science Information Center

Reports Section

Box 25286, MS 517

Denver Federal Center

Lakewood, CO 80225 


\section{CONTENTS}

Abstract. 1.1

Section 1--Introduction

Objectives and Scope.

Watershed Characteristics .................................................................................. 1.4

Land Use History ...................................................................................... 1.5

Climate, Precipitation Regime, and Hydrology ............................................. 1.7

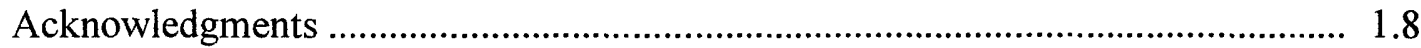

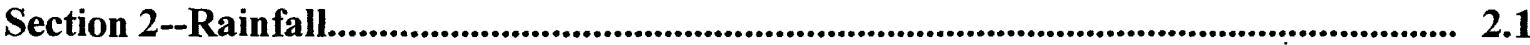

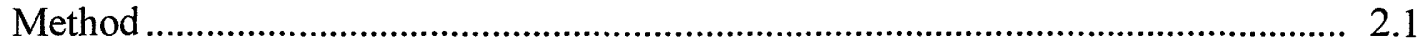

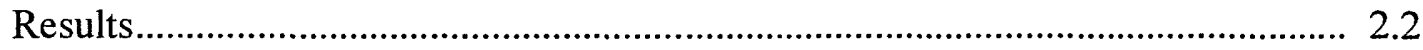

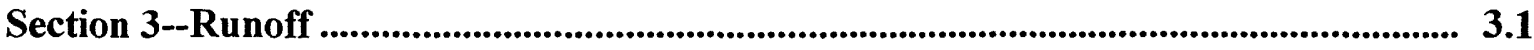

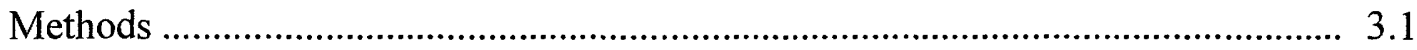

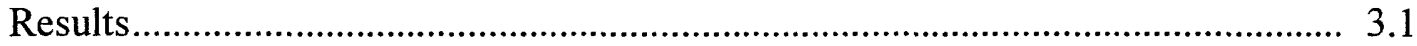

Discharge Rating Curve .................................................................... 3.1

Rainfall--Runoff Relation .................................................................... 3.3

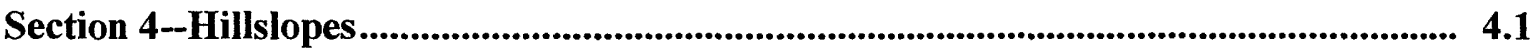

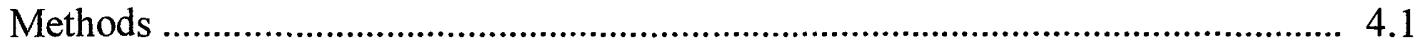

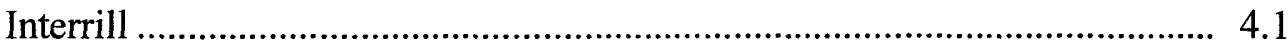

Hillslope Traps ...................................................................... 4.1

Particle-size Distribution ....................................................... 4.2

Rills .............................................................................................. 4.4

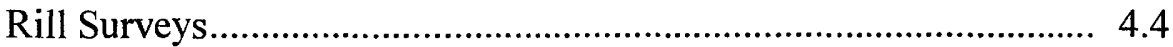

Rill Traps ..................................................................... 4.8

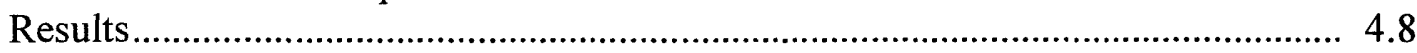

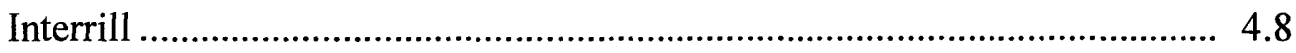

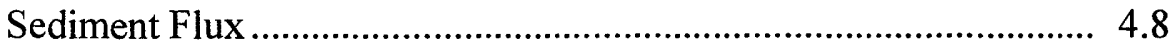

Particle-size Distribution ................................................................ 4.9

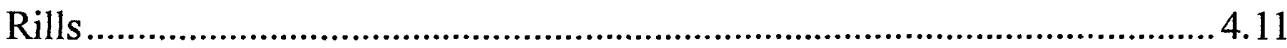

Rill Geometry ........................................................................ 4.11

Rill Evolution ........................................................................ 4.12

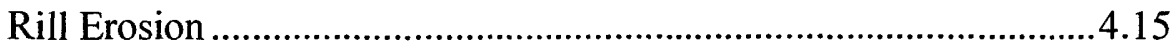

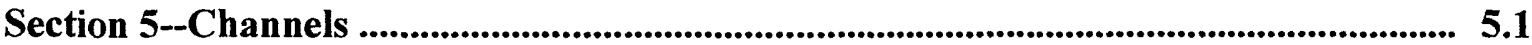

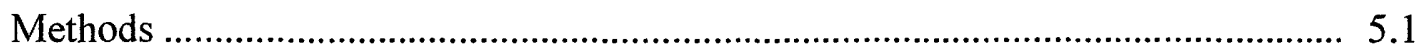

Main Channel.............................................................................. 5.1

Subwatersheds ......................................................................................... 5.3

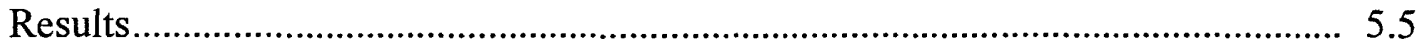

Main Channel....................................................................................... 5.5

Subwatersheds ............................................................................... 5.8

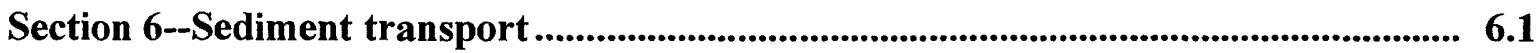

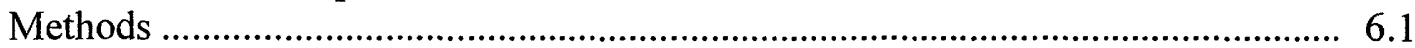

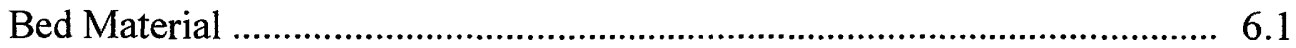

Direct Measurements ...................................................................... 6.1

Thresholds of Motion............................................................................ 6.3 


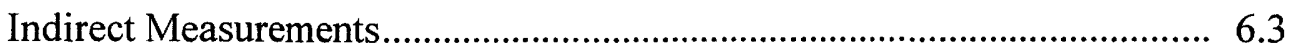

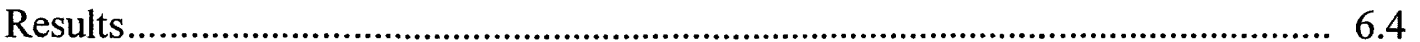

Bed Material ................................................................................................. 6.4

Total Load Rating Curves ............................................................................ 6.5

Initiation of Motion for Bed Load .................................................................. 6.7

Mobility of Coarse Sediment ....................................................................... 6.8

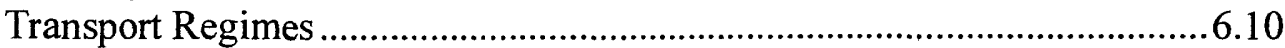

Bed-Load and Suspended-Load Rating Curves...............................................10

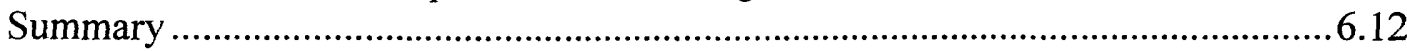

Section 7--Reservoir.......................................................................................................... 7.1

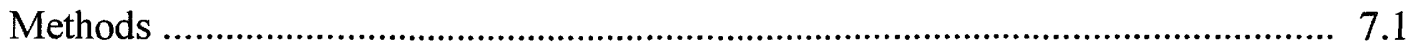

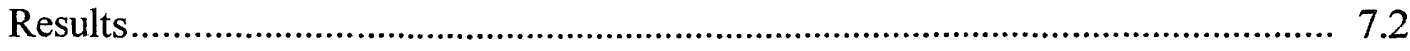

Sediment Deposition and Transport into the Reservoir................................... 7.2

Sediment Cores ..................................................................................... 7.5

References..................................................................................................................................... R.1 


\section{FIGURES}

Page

1.1 Location of the study sites within the two burned watersheds .............................. 1.3

1.2 Location of long-term regional precipitation stations .............................................. 1.6

2.1 Distribution of rainfall intensity $\left(I_{30}\right)$ at Spring Creek above mouth near South Platte, Colorado, during the summer (June, July, August, and September).

3.1 Measured discharges in Buffalo and Spring Creeks compared with those predicted by the critical flow model.

3.2 Relation between unit-area peak discharge and the 30 -minute maximum rainfall intensity, $\mathbf{I}_{30}$

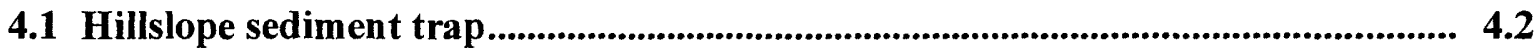

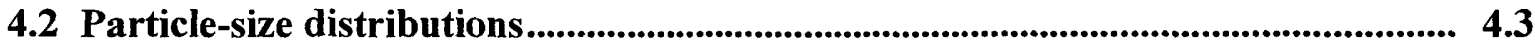

4.3A Maps of rill fields on south-facing hillslopes ................................................... 4.5

4.3B Map of rill 6 ........................................................................................................... 4.6

4.4A Equipment used for repeated measurements of rill cross sections......................... 4.7

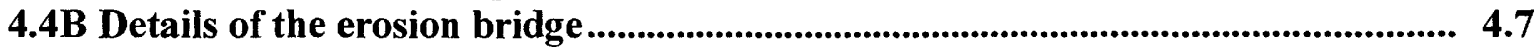

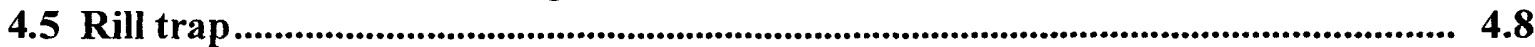

4.6 Seasonal change in median particle diameter and hillslope flux in the Spring Creek watershed.

4.7 Cross-sectional area of rills in the Spring Creek watershed plotted as a function of distance from the beginning of the rills.................................................4.12

4.8 Change in minimum bed elevation of rills with time.................................................4.13

4.9 Change in rill profiles with time .........................................................................4

4.10 Change in normalized rill-width ..................................................................................4.15

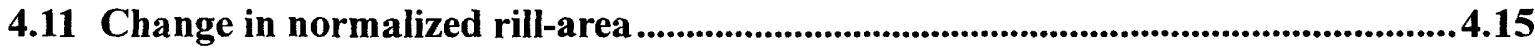

5.1 Buffalo Creek study reach ........................................................................................... 5.1

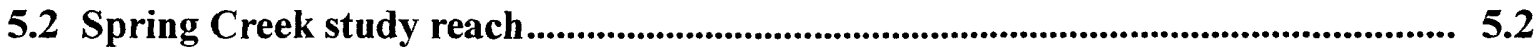

5.3 Subwatersheds in Spring Creek ............................................................................. 5.4

5.4 Three representative cross sections in Spring Creek.............................................. 5.6

5.5 Variation in the valley width of Spring Creek and the pre-flood bed slope in June and July 1996

5.6 Changes in erosion (negative) and deposition (positive) as a function of time and distance upstream from the mouth of Spring Creek........................... 5.8

5.7 Erosion of sediment as a function of contributing area..........................................5.10

5.8 Erosion of sediment as a function of cumulative stream-length ................................5.11

5.9 Relation between channel top-width and cumulative stream-length ......................5.12 
6.1 Sediment samplers

6.2 Comparison of the particle-size distribution of bed material in

Buffalo and Spring Creeks.

6.3 Distribution of particle shapes for the $11.3-16 \mathrm{~mm}$ size class of bed load in Spring Creek

6.4 Total sediment transport as a function of water discharge in Buffalo and Spring Creeks.

6.5 Initiation of motion of bed material as a function of relative roughness

6.6 Relative mobility of coarse sediment in Spring Creek

6.7 Bed-load and suspended-load transport per unit width as a function of water discharge per unit width in Spring Creek

6.8 Bed-load and suspended-load transport per unit width as a function of water discharge per unit width in Buffalo Creek

7.1 Strontia Springs Reservoir on the South Platte River near Denver

7.2 Longitudinal profiles of the upper part of Strontia Springs Reservoir

7.3 Stratigraphy of flood sediments at section 12-13 in Strontia Springs Reservoir .... 7.4

7.4 Changes in percent silt and clay and material lost on ignition (LOI) in a sediment core

7.5 Change in metal concentrations in a sediment core 7.7 


\section{TABLES}

1.1 Characteristics of Buffalo and Spring Creeks watersheds

1.2 Long-term precipitation and temperature records from

Cheesman, Kassler, and Strontia Springs Dam, Colorado

2.1 U. S. Geological Survey rain gages in the Buffalo Creek and Spring Creek watersheds

2.2 Rainfall characteristics for four years after the Buffalo Creek Fire

3.1 Summary of discharge measurements for Buffalo Creek, 1997-2000

3.2 Summary of discharge measurements for Spring Creek, 1997-2000

3.3 Rainfall intensity and peak discharges for the Spring Creek watershed, 1997-2000

3.4 Pre-fire flood characteristics in the watersheds burned by the Buffalo Creek Fire, 1996-2000

3.5 Geometric characteristics for the channel cross section at the Spring Creek gage.

4.1 Summary of particle-size distribution and the flux of sediment into north-facing hillslope traps in a severely burned area of the Spring Creek watershed, 1997-2000

4.2 Summary of particle-size distribution and the flux of sediment into south-facing hillslope traps in a severely burned area of the Spring Creek watershed, 1997-2000

4.3 Summary of particle-size distribution and the flux of sediment into north-facing hillslope traps in an unburned area of the Spring Creek watershed, 1998-2000

4.4 Summary of particle-size distribution and the flux of sediment into south-facing hillslope traps in an unburned area of the Spring Creek watershed, 1998-2000

4.5 Summary of the seasonal flux of sediment into hillslope traps in a severely burned and an unburned area of the Spring Creek watershed, 1997-2000

4.6 Summary of particle-size distribution of hillslope material in the Spring Creek and Buffalo Creek watersheds.

4.7 Sediment size and flux data for rill traps on a south-facing hillslope in the Spring Creek watershed

4.8 Comparison of the geometry of hydraulic channels formed by unsteady and steady flow processes

4.9 Summary of cross-sectional area of rills in the Spring Creek watershed 
5.1 Erosion and deposition at selected channel cross-sections in the Spring Creek study area.

5.2 Change in volume of sediment stored in the channel near the mouth of Spring Creek

5.3 Change in volume of sediment stored in the channel near the mouth of Buffalo Creek

5.4 Characteristics and erosion volumes for drainages in two subwatersheds in the Spring Creek watershed

6.1 Summary of the particle-size distribution of surficial bed material in Spring Creek and Buffalo Creek after the wildfire and floods in 1996

6.2 Summary of the particle-size distribution of surficial bed material in the Spring Creek channel and one of its tributaries after the wildfire and floods in 1996 and 1997

6.3 Summary of the particle-size distribution of replicate samples of bed and suspended load collected near the mouth of Spring Creek, 1997-2000

6.4 Summary of the particle-size distribution of replicate samples of bed and suspended load collected near the mouth of Buffalo Creek, 1997-2000.

6.5 Summary of sediment transport measurements in Spring Creek, 1997-2000.

6.6 Summary of sediment transport measurements in Buffalo Creek, 1997-2000 .......6.21

6.7 Threshold data for bed-load movement in Spring Creek

6.8 Threshold data for bed-load movement in Buffalo Creek

6.9 Summary of total sediment transport estimates in Spring Creek for selected flash floods based on the change in volume of sediment in the study reach.

6.10 Bed-load transport efficiencies for selected streams and rivers ..............................6.26

6.11 Ratio of the percent sediment transported as bed load to the percent sediment available in the bed of Spring Creek.

6.12 Ratio of the percent sediment transported as bed load to the percent sediment available in the bed of Buffalo Creek.

7.1 Measurements of coarse (sand and gravel) sediment transport into Strontia Springs Reservoir based on change in sediment volume in the reservoir

7.2 Summary of particle-size distribution of fire-related sediments collected from Strontia Springs Reservoir and upstream from Marston Diversion Dam

7.3 Metals associated with hillslope source material and fire-related bed sediment in Strontia Springs Reservoir 


\section{APPENDICES}

1. Format of rill files

2. Coordinates and elevation of reference pins for cross sections of rills on a south-facing hillslope in the Spring Creek watershed

3. Summary of stereo photographs for the two watersheds burned by the Buffalo Creek Fire.

4. Average arbitrary coordinates and adjustments for reference pins located at either end of cross sections in Spring Creek

5. Average arbitrary coordinates and adjustments for reference pins located at either end of cross sections in Buffalo Creek

6. UTM coordinates and arbitrary coordinates for selected reference pins near the mouth of Spring Creek.

7. UTM coordinates for cross section end points in Spring Creek.................................. A.7

8. Format of cross-section and transect files for Spring Creek ...........................................10

9. Format of cross-section and transect files for Buffalo Creek ..........................................12

10. Information for erosion and deposition files for Spring and Buffalo Creeks...........A.13

11. Formats for erosion data collected in watersheds W960 and W1165.......................A.14

12. Interpolated particle-size distribution for the bed material in Spring Creek..........A.15

13. Distances from station 15 in Strontia Springs Reservoir along the center line of the reservoir

14. Longitudinal bathymetric surveys of Strontia Springs Reservoir A.17 


\section{CONVERSION FACTORS AND DEFINITION OF SYMBOLS}

$\underline{\text { Multiply }}$

meter (m)

square meter $\left(\mathrm{m}^{2}\right)$

hectare (ha)

cubic meter $\left(\mathrm{m}^{3}\right)$

meter per second $(\mathrm{m} / \mathrm{s})$

cubic meter per second $\left(\mathrm{m}^{3} / \mathrm{s}\right)$

gram (g

kilogram (kg)

newton $(\mathrm{N})$
By

3.281

10.76

2.471

1.308

7.235 $\underline{\text { To obtain }}$

foot $(\mathrm{ft})$

square foot $\left(\mathrm{ft}^{2}\right)$

acres

cubic yard $\left(\mathrm{yd}^{3}\right)$

foot per second $(\mathrm{ft} / \mathrm{s})$

cubic feet per second $\left(\mathrm{ft}^{3} / \mathrm{s}\right)$

ounce avoirdupois $(\mathrm{oz})$

pounds (lb)

slug (slug)

\section{SYMBOLS}

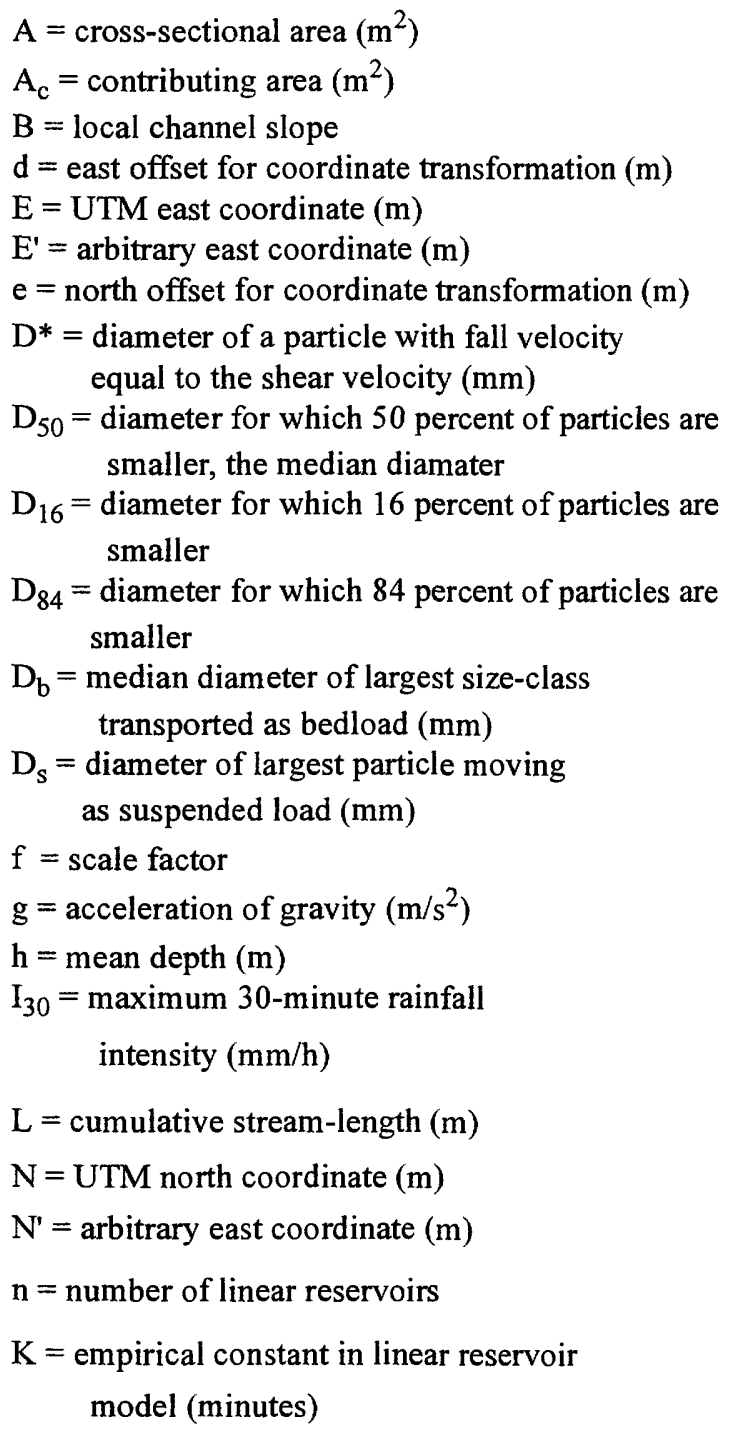

$\mathrm{Q}=$ discharge $\left(\mathrm{m}^{3} / \mathrm{s}\right)$

$\mathrm{R}=$ hydraulic radius $(\mathrm{m})$

$\mathrm{S}=$ water surface slope

$\mathrm{Sc}=$ Cory shape factor

$\mathrm{u}^{*}=$ shear velocity $(\mathrm{m} / \mathrm{s})$

$\mathrm{w}=$ channel top width $(\mathrm{m})$

$\mathrm{w}_{\mathrm{z}}=$ fall or settling velocity $(\mathrm{m} / \mathrm{s})$

$Z=$ elevation above sea level (m)

$Z^{\prime}=$ arbitrary elevation above sea level $(\mathrm{m})$

$z=$ elevation offset for coordinate transformation (m)

$\theta=$ rotation angle (degees)

$\alpha=$ minor axis of sediment particle ( $\mathrm{mm}$ )

$\beta=$ minor axis of sediment particle $(\mathrm{mm})$

$\gamma=$ major axis of sediment particle $(\mathrm{mm})$

$v=$ kinematic viscosity of water $\left(\mathrm{m}^{2} / \mathrm{s}\right)$

$\rho s=$ density of sediment $\left(\mathrm{kg} / \mathrm{m}^{3}\right)$

$\rho=$ density of water $\left(\mathrm{kg} / \mathrm{m}^{3}\right)$

$\sigma=$ sorting or dispersion coefficient

$\phi_{1}=$ slope of the side of the channel perpendicular to axis

$\phi_{2}=$ slope of the side of the channel perpendicular to axis

$\tau=$ shear stress $\left(\mathrm{N} \mathrm{m}^{-2}\right)$

$\tau^{*}=$ non-dimensional shear stress

$\tau^{*}{ }_{c}=$ non-dimensional shear stress required to initiate motion 


\title{
HYDROLOGIC AND SEDIMENTOLOGIC RESPONSE OF TWO BURNED
}

\section{WATERSHEDS IN COLORADO}

\author{
John A. Moody and Deborah A. Martin
}

\begin{abstract}
A wildfire in May 1996 burned two mountain watersheds southwest of Denver, Colorado. In June and July 1996, intense rain from several thunderstorms caused erosion of sediment from hillslopes and channels in these two watersheds, resulting in deposition of sediment in Strontia Springs Reservoir, a major water-supply reservoir for the cities of Denver and Aurora. A study was begun in 1997 to measure the hydrologic and sedimentologic responses of these burned watersheds to subsequent rainstorms.

The rainfall characteristics after the wildfire indicate that 1997 was an above average year for rainfall. The rainfall-runoff relation indicates that a threshold of rainfall intensity exists, above which severe flash floods occur. The sediment-erosion rates on the hillslope decreased from a maximum of at least $0.048 \mathrm{~kg} / \mathrm{m} / \mathrm{d}$ (kilograms per meter per day) in 1997 to an average of $0.00054 \mathrm{~kg} / \mathrm{m} / \mathrm{d}$ in 2000 which approached the pre-fire rate. Sediment transport from the watersheds after the wildfire was 5-10 times greater than before the wildfire but also decreased during the four years of the post-fire study. Sediment from the initial erosion in 1996 is still stored in the channels of the watersheds. Near the mouth of one watershed there has been a net aggradation of the bed while near the mouth of the other watershed the channel has been scoured back down to the pre-fire level. Initial deposition in the Strontia Springs Reservoir was $52,000 \mathrm{~m}^{3}$ (cubic meters) of coarse sand and gravel, which created a delta in the upper end of the reservoir, and $100,000 \mathrm{~m}^{3}$ of silt and clay near the dam. Subsequent deposition in the reservoir has added about $200,000 \mathrm{~m}^{3}$ of coarse sand and gravel and an unmeasured amount of silt and clay.

Recovery of these burned watersheds within about five years seems typical as documented in the scientific literature; however, the reader should be cautious about assuming that runoff and erosion will continue to decrease. The runoff and erosion response was only monitored for four years after the Buffalo Creek Fire and the rainfall has been normal or below normal since 1997.
\end{abstract}




\section{Section 1-INTRODUCTION}

In May 1996, the Buffalo Creek Fire burned approximately $50 \mathrm{~km}^{2}$ in the Pike National Forest southwest of Denver, Colorado. The fire burned two adjacent sixth-level watersheds (U.S. Forest Service, 1995), Buffalo Creek and Spring Creek (fig. 1.1). A larger proportion of the Spring Creek watershed burned, 79 percent, compared with the Buffalo Creek watershed, 21 percent (table 1.1). Bruggink and others (1998), characterized the majority of the burned area as severely burned ( 63 percent), based on the consumption of litter and duff and the visible effects of the fire on the needles and branches of conifers, the predominant woody vegetation. Two months after the fire, an intense rainstorm (110 $\mathrm{mm}$ in an hour; Jarrett, 2001) caused severe flooding, erosion, and the death of two people. The flood transported large quantities of sediment and organic debris to Strontia Springs Reservoir on the South Platte River, a major water-supply reservoir for the cities of Denver and Aurora. The Denver Water Department and the U.S. Forest Service provided funding to assess the potential impact of sediment erosion in the burned watersheds and on the downstream water-supply systems.

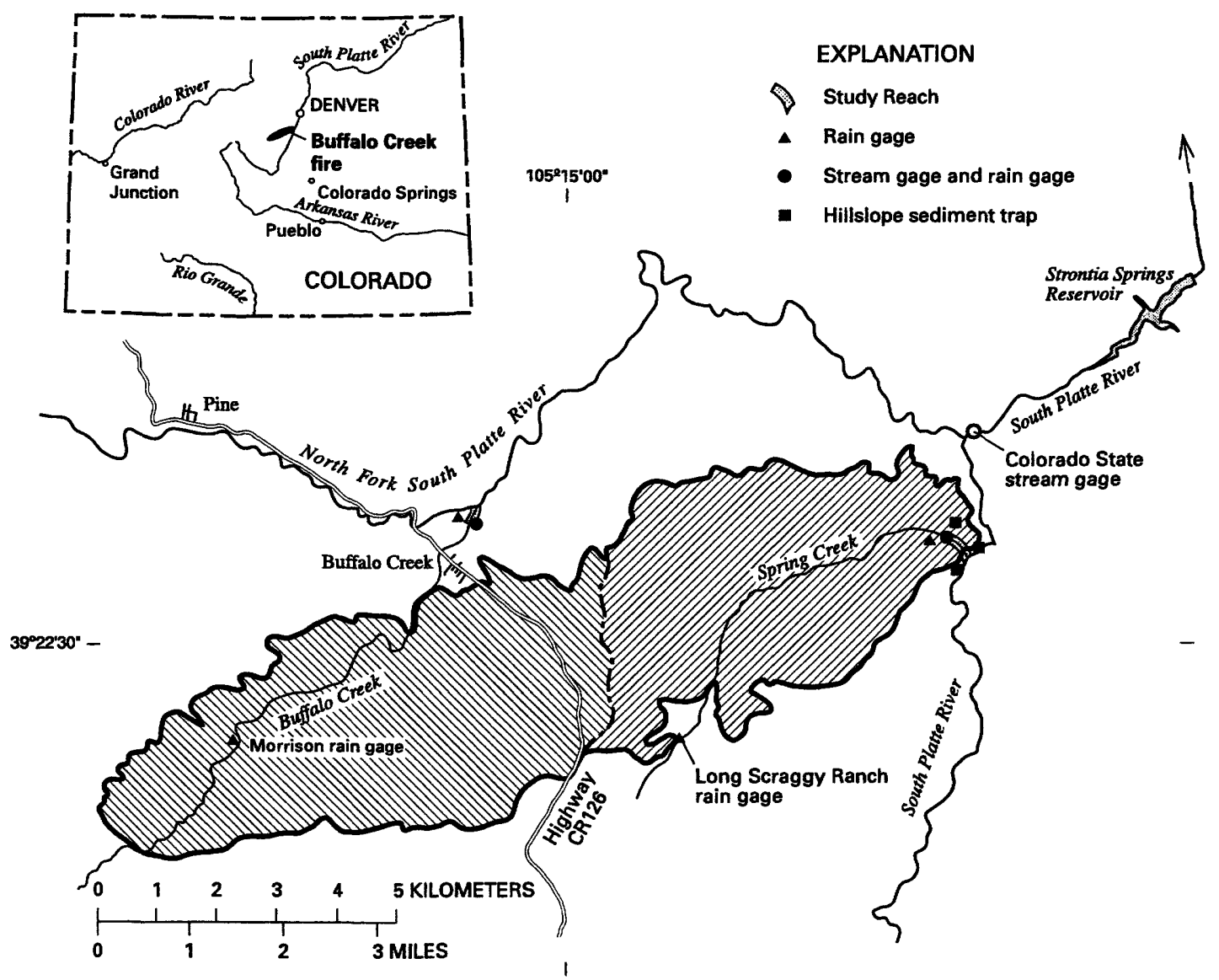

Figure 1.1 Location of the study sites within the two burned watersheds. 


\section{Objectives and Scope}

Following the fire, the U.S. Geological Survey (USGS) initiated several studies in the two burned watersheds. The objectives of these studies were: (1) to use rainfall and stream gage data to develop a rainfall-runoff relation for burned watersheds; (2) to measure the hydrological and erosional responses of severely burned hillslopes by monitoring hillslope runoff, erosion in rills, and erosion from inter-rill areas; (3) to measure erosion and deposition in first to fourth order drainages; (4) to measure the volume of post-fire sediment deposited in the channels and monitor the flux of sediment from the watersheds; (5) to develop sediment rating curves for the two burned watersheds and compare these curves with pre-fire curves; and (6) to monitor the flux of sediment into Strontia Springs Reservoir. These studies began in 1996 and are planned to monitor the recovery of the burned watersheds over a long period of time. This report presents results from studies conducted from 1996 through 2000. Most efforts have been in the Spring Creek watershed because more extensive post-fire rehabilitation was carried out in the Buffalo Creek watershed, and an overall objective is to understand the "natural" response to and recovery from wildfire.

\section{Watershed Characteristics}

Buffalo and Spring Creek watersheds are located in the Front Range of the Rocky Mountains, underlain by the Pikes Peak batholith. They cover an elevation range of 1,880 to $3,180 \mathrm{~m}$ (table 1.1). Soils belong to the Sphinx-Legault-Rock outcrop complex (Moore, 1992). Depths to bedrock are quite variable, and the soil profile includes emerging corestones and thick layers of

Table 1.1. Characteristics of Buffalo and Spring Creeks watersheds

[ha, hectare; $\mathrm{m}$, meter; $\mathrm{km}$, kilometer; $\mathrm{m}^{3} / \mathrm{s}$, cubic meter per second]

\begin{tabular}{|c|c|c|}
\hline Characteristics & Buffalo Creek & Spring Creek \\
\hline Watershed level & 6 & 6 \\
\hline Watershed area (ha) & 12,240 & 2,680 \\
\hline Burned area (ha) & 2,570 & 2,120 \\
\hline Elevation range (m) & $2,010-3,180$ & $1,880-2,360$ \\
\hline Relief ratio in the burned area & 0.020 & 0.046 \\
\hline Main channel length in burned area $(\mathrm{km})$ & 7.3 & 5.9 \\
\hline Channel lengths in burned area (km) & $180^{\mathrm{a}}$ & 150 \\
\hline Bifurcation ratio & $3.9^{\mathrm{b}}$ & 4.1 \\
\hline Average valley width near mouth (m) & 35 & 27 \\
\hline Range in channel width near mouth (m) & $3-13$ & $1-26$ \\
\hline Main channel slope (\%) & $1-2$ & $3-4$ \\
\hline Channel density $(1 / \mathbf{k m})$ & $7.1^{\mathrm{b}}$ & 6.9 \\
\hline $\begin{array}{l}\text { Distance of mouth from Strontia Springs Reser- } \\
\text { voir }(\mathbf{k m})\end{array}$ & 18 & 4.8 \\
\hline Baseflow: June, July, August $1997-98\left(\mathrm{~m}^{3} / \mathrm{s}\right)$ & 0.7 & 0.07 \\
\hline
\end{tabular}

${ }^{a}$ Channel length is equal to channel density times the burned area.

${ }^{b}$ This value is the average of three subwatersheds. 
decomposed granite called grüs, similar to the conditions described by Isherwood and Street (1976) for the Boulder, Colorado, batholith. In general, however, the soils of the Sphinx-LegaultRock outcrop complex are shallow (about $0.4 \mathrm{~m}$ to the weathered bedrock), well to excessively drained, and low in organic matter ( 2 percent or less). Material mantling the hillslope is generally coarse (about 7 percent silt and clay, 35 percent sand, 58 percent gravel) with a median diameter of 2.6 to $2.9 \mathrm{~mm}$ (Martin and Moody, 2001). Soils are classified as Typic Ustorthents on southfacing hillslopes and as Typic Cryorthents on north-facing hillslopes (Blair, 1976; Moore, 1992; Welter, 1995). These soils have a typical erodibility factor, $\mathrm{K}$ (Renard and others, 1997), of 0.49 $\mathrm{m}^{-1}$, a high runoff potential when thoroughly wet (primarily because of the very shallow depth to bedrock), and are considered to be highly erodible if the soil cover is disturbed (Moore, 1992).

The vegetation growing on these soils is montane forest with ponderosa pine (Pinus ponderosa) and some Rocky Mountain juniper (Juniperus scopulorum) occurring mainly on southand west-facing slopes, and Douglas-fir (Pseudotsuga menziesii) on the north- and east-facing slopes, though a mix of all tree species can occur on any aspect. The litter and duff layer, consisting mainly of undecomposed to partially decomposed conifer needles, is thick (75-100 mm; Jarrett, 2001) and fairly extensive, especially on the north- and east-facing aspects. Like much of the Colorado Front Range, both extensive grazing and active fire suppression for over 100 years have allowed tree densities to increase above the densities typical of the pre-fire suppression era (Brown and others, 1999; Kaufmann and others, 2000a, 2000b). Very little understory vegetation exists on unburned north-facing slopes because of competition for light and nutrients under the closed Douglas fir canopy. However, after the fire the north-facing, burned hillslopes have developed a dense cover of herbaceous vegetation (including creeping dogbane, Apocynum androsaemifolium, sugarbowl, Clematis hirsutissima, and leafy spurge, Euphorbia esula). On southand west-facing aspects, the litter and duff layer occurs mainly under ponderosa pines, bunch grasses (Arizona fescue, Festuca arizonica, and others; Moore, 1992), and shrubs (Gambel oak, Quercus gambeli). Bare ground is common on the hillslopes between trees, grasses, and shrubs. Except for ponderosa pine and Rocky Mountain juniper, this assemblage of vegetation has recovered to almost pre-fire conditions on burned south-facing slopes. Before the fire, the riparian vegetation in Spring Creek consisted of stands of willow (Salix ssp.) and narrowleaf cottonwood (Populus angustifolia) (Moore, 1992; U.S. Forest Service, 1996). Along Spring Creek, after the fire, most of the riparian vegetation was either buried by sediment or scoured out by the post-fire flooding, while along Buffalo Creek, the riparian zone had more coniferous trees and was less scoured by the post-fire flooding.

\section{Land Use History}

The two watersheds have a well-documented land-use history since the turn of the century. This history indicates that erosion has occurred in this area as a result of fire and human activities. In 1899 both the Buffalo Creek and Spring Creek watersheds were part of the South Platte Forest Reserve administered by the USGS (Jack, 1900). The Forest Reserves had been set aside to protect land and water supplies for the Nation under the Forest Reserve Act of 1891 (Steen, 1991). After the creation of the U.S. Forest Service in 1905, the study area became part of the Pike National Forest in 1907. Jack (1900) describes the extent of area burned within the adjacent South Platte, Plum and Pikes Peak Forest Reserves: "Probably at least 75 percent of the total area of the reserves clearly shows damage by fire, much of it within the last half century or since the advent of white settlers in the region; and a great deal of ground shows traces of fires, which must have occurred prior to that time, and the forest has partially recovered the areas then burned over." The 
area is also described as having "excessive pasturage, by which the ground becomes trampled hard and the protecting vegetation along streams destroyed" (Jack, 1900, p. 43). A 1938 U.S. Forest Service report (Connaughton, 1938) documented significant erosional consequences of overgrazing in the Spring Creek watershed and recommended reducing the number of livestock

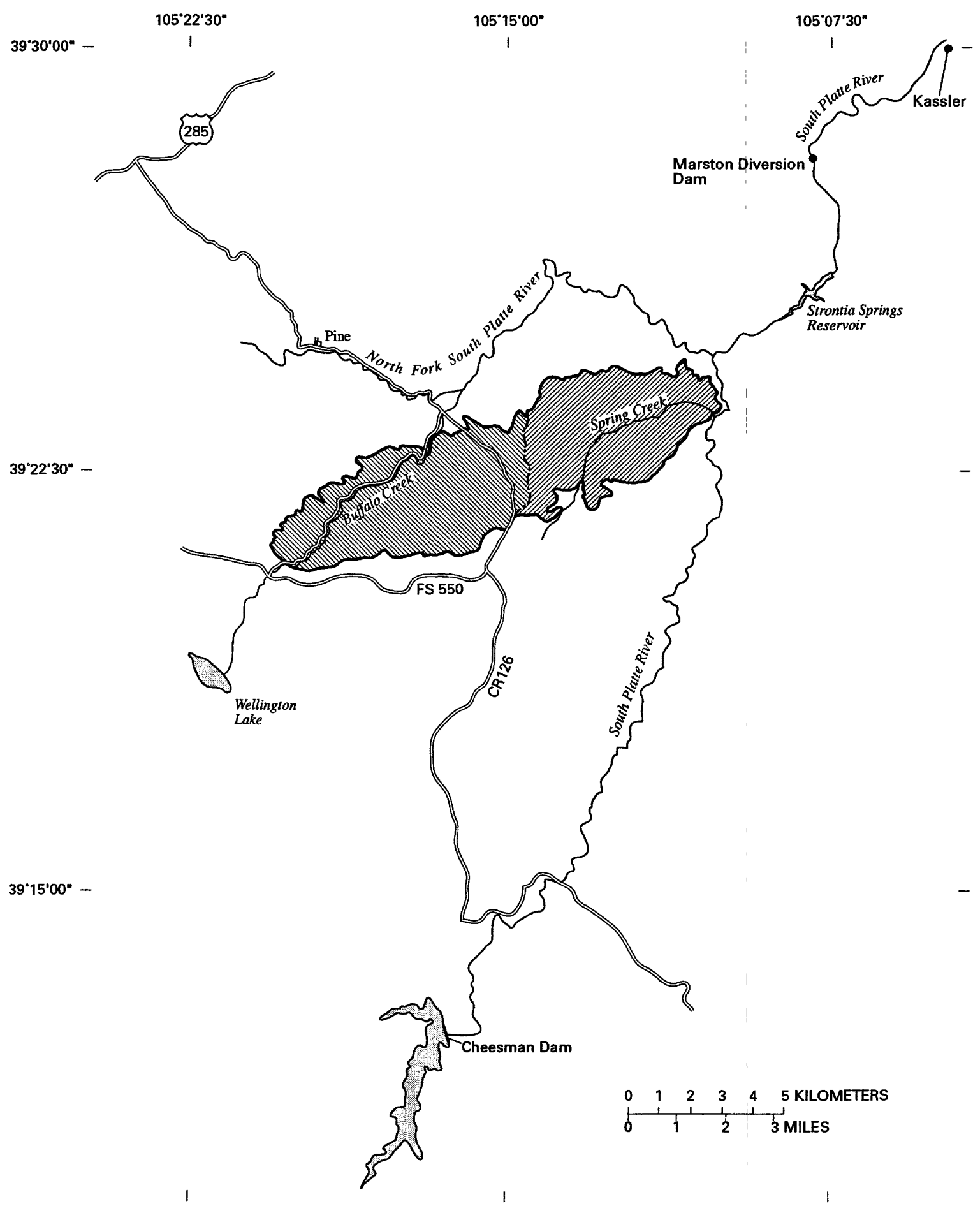

Figure 1.2 Location of long-term regional precipitation stations. 
allowed to graze the land. Ample evidence, including reports and archival photography, indicates that this area is highly susceptible to erosion as a result of both fire and overgrazing. Stratigraphic evidence suggests that fire followed by significant erosion may be a process active for at least the last two thousand years (Elliott, 1999; Gonzales and Hunt, 1999; Elliott and Parker, 2001).

\section{Climate, Precipitation Regime, and Hydrology}

The climate is semi-arid, and precipitation is dominated by intense summer convective storms and winter snow storms. Based on long-term precipitation and temperature means from nearby weather stations at Cheesman, Kassler and Strontia Springs Dam (fig. 1.2), about onethird to one-half of the precipitation occurs during the summer months of June through September (table 1.2). According to Jarrett (1990) flooding in this area mainly results from intense, localized thunderstorms, but can also result from generalized rainstorms and spring snowmelt. Rainfall

\section{Table 1.2. Long-term precipitation and temperature records from Cheesman, Kassler, and Strontia Springs Dam, Colorado}

[Source: Colorado Climate Center, $2001 ; \mathrm{m}$, meter; mm, millimeter; ${ }^{\circ} \mathrm{C}$, degree Celsius]

\begin{tabular}{|c|c|c|c|}
\hline Characteristics & Cheesman & Kassler & $\begin{array}{l}\text { Strontia } \\
\text { Springs Dam }\end{array}$ \\
\hline National Weather Service station ID & 51528 & 54452 & 58022 \\
\hline Latitude & $39^{\circ} 13^{\prime}$ & $39^{\circ} 30^{\prime}$ & $39^{\circ} 26^{\prime}$ \\
\hline Longitude & $105^{\circ} 17^{\prime}$ & $105^{\circ} 06^{\prime}$ & $105^{\circ} 07^{\prime}$ \\
\hline Elevation (m) & 2,100 & 1,676 & 1,780 \\
\hline Period of record & $1950-1997$ & $1950-1997$ & 1984-1997 \\
\hline Mean annual precipitation (mm) & 420 & 442 & 566 \\
\hline $\begin{array}{c}\text { Total summer (June through September) } \\
\text { precipitation (mm) }\end{array}$ & 205.7 & 161.3 & 229.4 \\
\hline $\begin{array}{l}\text { Average number of summer days with } \\
\text { precipitation } \geq 2.54 \mathrm{~mm}\end{array}$ & 21.3 & 15.8 & 22.8 \\
\hline $\begin{array}{l}\text { Average number of summer days with } \\
\text { precipitation } \geq 25.4 \mathrm{~mm}\end{array}$ & 0.9 & 1.0 & 1.2 \\
\hline Mean annual maximum temperature $\left({ }^{\circ} \mathrm{C}\right)$ & 17 & 19 & 17 \\
\hline Mean annual minimum temperature $\left({ }^{\circ} \mathrm{C}\right)$ & -3 & 2 & -1 \\
\hline
\end{tabular}

intensities during these storms range from about $30 \mathrm{~mm} / \mathrm{h}$ for the 2-year recurrence storm to about $60 \mathrm{~mm} / \mathrm{h}$ for the 100-year recurrence storm (Miller and others, 1973)

Before the wildfire, Spring Creek had ephemeral and intermittent reaches (Casey Clapsaddle, U.S. Forest Service, oral. commun., 1997) with beaver ponds in certain reaches, as shown in photographs taken soon after the wildfire (D. Bohon, U.S. Forest Service, oral commun., 1997). At present (2001), the stream is still intermittent, disappearing below the sediment in the channel in several reaches. Spring Creek flows into the South Platte River $4.8 \mathrm{~km}$ above Strontia Springs 
Reservoir (fig. 1.2).

Before the wildfire, Buffalo Creek was a perennial stream with a gravel and cobble bed and little suspended sediment load (Williams and Rosgen, 1989). Water is released each summer for irrigation from Wellington Lake (fig. 1.2) by the Burlington/Wellington Ditch Company. Buffalo Creek flows into the North Fork of the South Platte River $18 \mathrm{~km}$ above Strontia Springs Reservoir. The North Fork of the South Platte and the South Platte flow together near the historic town site of South Platte, $1.6 \mathrm{~km}$ above Strontia Springs Reservoir. The State of Colorado operates a stream gage (South Platte River at South Platte) just below the confluence.

\section{Acknowledgments}

The authors particularly wish to thank Bob Weir (retired), Denver Water Department, for his support, enthusiasm and vision, and Jeff Bruggink, U.S. Forest Service, for his support and cooperation. The authors thank Jim Weldon and John Gaborek for the continued support of the Denver Water Department through 2000. Several people collected and processed samples, surveyed, or provided other support. The authors especially thank Lisa Pine and Tanya Ariowitsch for long hours of sieving and data analysis. The authors extend warm thanks to Craig Allen, Greg Alexander, Brent Barkett, Jim Bennett, Jeff Blossom, Régis Braucher, Allen Gellis, Eleanor Griffin, David Kinner, Paul Kinzel, Holly Martinson-Denlinger, Bob Meade, Terry Plowman, Mark Richards, Pete Robichaud, Bob Stallard, Scott Tangenberg, Howard Taylor, and Peter Wohlgemuth for a variety of inputs to the study too numerous to mention in detail. And finally, thanks to Jim Bennett, John Flager, Eleanor Griffin, Leo House, and Cathy Rubin for their careful reviews and suggested improvements to this manuscript. 


\section{Section 2-RAINFALL}

\section{Method}

In response to the threat of post-fire flooding and erosion, the USGS and the Denver Water Department cooperatively installed four rain gages in or near the area burned by the Buffalo Creek fire. Two rain gages were deployed in the Spring Creek watershed and two in the Buffalo Creek watershed (table 2.1). The locations of the four gages were chosen on the basis of results of Troutman (1982). Prior to the fire, no official rain gages were operated in the vicinity of the burn, though local residents have provided rainfall data (Jarrett, 2001). Other methods, such as radar and paleohydrologic techniques (Henz, 1998; Fulton, 1999; Yates and others, 2000; Jarrett, 2001), have been used to reconstruct the storm that caused the initial post-fire flooding on 12 July 1996.

The rain gages are being used to monitor rainfall in the burned area and to collect rainfall intensities for the development of rainfall-runoff relations for the burned watersheds. The rain gages are either Meteorology Research or Met One tipping-bucket rain gages with 8-inch orifices. The tipping buckets have a 0.01 -inch capacity. Sutron 8210 data collection platforms record data at 5-minute intervals. The rain gages have operated on a seasonal basis, April-September of each year, since they were installed (USGS, 1997, 1998, 1999, and 2000). Every 4 hours under

\section{Table 2.1. U. S. Geological Survey rain gages in the Buffalo Creek and Spring Creek watersheds}

[These gages are operated from April through September of each year. Current and historic data are available on the Web at http://www.usgs.gov]

\begin{tabular}{lcccc}
\hline & $\begin{array}{c}\text { Buffalo Creek } \\
\text { at Buffalo } \\
\text { Creek, } \\
\text { Colorado }\end{array}$ & $\begin{array}{c}\text { Buffalo Creek at } \\
\text { Morrison Creek }\end{array}$ & $\begin{array}{c}\text { Spring Creek at } \\
\text { Long Scraggy } \\
\text { Ranch }\end{array}$ & $\begin{array}{c}\text { Spring Creek } \\
\text { above mouth } \\
\text { near South } \\
\text { Platte, } \\
\text { Colorado }\end{array}$ \\
\hline U.S. Geological Survey ID & 06706800 & 392133105184401 & 392144105132401 & 06701970 \\
Latitude & $39^{\circ} 23^{\prime} 2^{\prime \prime}$ & $39^{\circ} 21^{\prime} 3^{\prime \prime}$ & $39^{\circ} 21^{\prime} 4^{\prime \prime}$ & $39^{\circ} 23^{\prime} 3^{\prime \prime}$ \\
Longitude & $15^{\circ} 16^{\prime} 1^{\prime \prime}$ & $105^{\circ} 18^{\prime} 4^{\prime \prime}$ & $105^{\circ} 13^{\prime} 2^{\prime \prime}$ & $15^{\circ} 11^{\prime} 01^{\prime \prime}$ \\
Elevation (meters) & 2,021 & 2,170 & 2,219 & 1,926 \\
Start date & 22 June 1997 & 10 April 1997 & 24 April 1997 & 24 April 1997 \\
& & & & \\
\hline
\end{tabular}

normal conditions, the Sutron data collection platforms transmit 15-minute values by a satellite connection. If the rain gage tipping rate exceeds a pre-set threshold, the data are transmitted in random mode, usually on 5-minute intervals for 15 minutes, unless the rain rates continue to exceed the pre-set threshold. 
Rainfall data were used to calculate 30 -minute rainfall intensities, storm duration, and total rainfall. To determine rainfall intensity, a moving 30-minute window was applied to an entire rainstorm to identify that part of the storm that had the highest 30-minute intensity, which was expressed in $\mathrm{mm} / \mathrm{h}$ in order to compare this intensity with values reported in the literature.

\section{$\underline{\text { Results }}$}

The number of rainstorm events, rainfall intensities, and total rainfall have varied throughout the four summers (1997-2000) for the two burned watersheds; in general, these properties seem to have decreased after 1997 (fig. 2.1, table 2.2). Summer is defined as June, July, August and September, a total of 122 days. Because the USGS rain gages were not installed until 1997, no rainfall data exist for the first summer following the wildfire (summer 1996) except for the radar (Henz, 1998; Fulton, 1999; Yates and others, 2000) and paleohydrologic (Jarrett, 2001) reconstructions for the 12 July 1996 storm. The summer of 1997 had more rain, a greater number of storms, and more intense rainfall than the other years of this study. In addition, 1997 appears to have been wetter than long-term averages. For example, at the USGS rain gage (Spring Creek above the

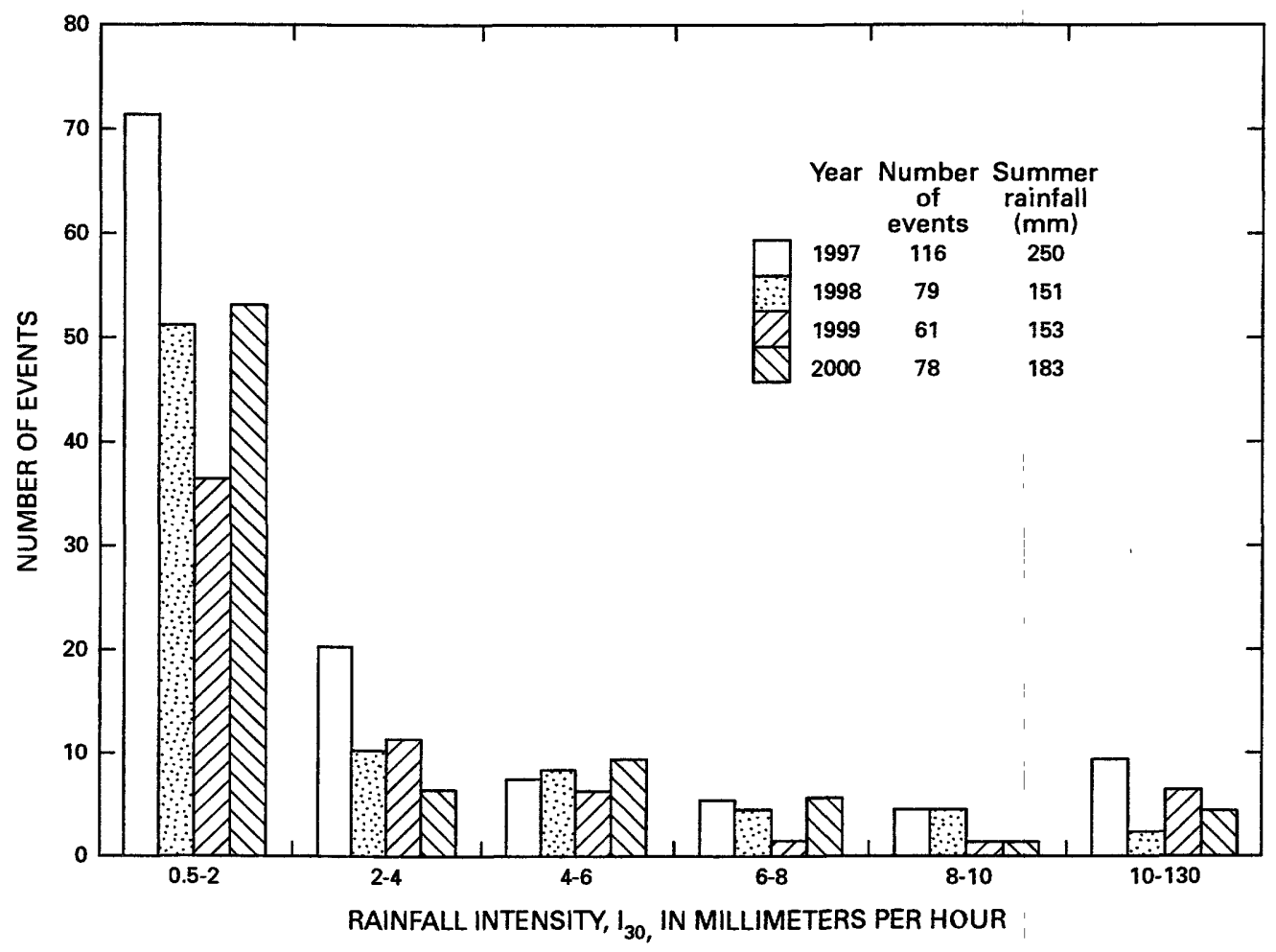

Figure 2.1. Distribution of rainfall intensity $\left(\mathrm{I}_{30}\right)$ at Spring Creek above mouth near South Platte, Colorado, during the summer (June, July, August, and September).

mouth near South Platte), the total summer rainfall $(250 \mathrm{~mm})$ was greater than the long-term averages of 205.7, 161.3 and $229.4 \mathrm{~mm}$ for the stations at Cheesman, Kassler, and Strontia Springs Dam, respectively. There were 24 days when the rainfall was greater than or equal to $2.54 \mathrm{~mm}$ compared with an average of 20 days for the long-term stations. In general, more rain events occurred in four of the six intensity classes in 1997 than in 1998, 1999, or 2000 (fig. 2.1). 
Table 2.2. Rainfall characteristics for four years after the Buffalo Creek Fire

[Rainstorms are separated by more than 15 minutes; $\mathrm{mm}$, millimeter; $\mathrm{h}$, hour; $\mathrm{mm} / \mathrm{h}$, millimeter per hour]

\begin{tabular}{|c|c|c|c|c|}
\hline & \multicolumn{4}{|c|}{ Summer months of June, July, August, and September } \\
\hline & 1997 & 1998 & 1999 & 2000 \\
\hline Total precipitation (mm)--at Morrison Creek & 224 & 123 & 132 & 159 \\
\hline $\begin{array}{l}\text { Total precipitation (mm)- at Buffalo } \\
\text { Creek }\end{array}$ & $\begin{array}{l}\text { gage was not } \\
\text { operating in June }\end{array}$ & 197 & 159 & 144 \\
\hline $\begin{array}{l}\text { Total precipitation (mm)--at Long Scraggy } \\
\text { Ranch }\end{array}$ & 288 & 270 & 263 & 194 \\
\hline \multicolumn{5}{|c|}{ Spring Creek above mouth near South Platte, Colorado } \\
\hline Total precipitation (mm) & 250 & 151 & 153 & 185 \\
\hline Number of rainstorms & 116 & 79 & 61 & 78 \\
\hline Number of days with precipitation $\geq 2.54 \mathrm{~mm}$ & 24 & 20 & 14 & 19 \\
\hline Number of days with precipitation $\geq 25.4 \mathrm{~mm}$ & 1 & 0 & 1 & 1 \\
\hline Mean duration (h) & 0.44 & 0.58 & 0.70 & 0.48 \\
\hline Median duration (h) & 0.25 & 0.33 & 0.50 & 0.25 \\
\hline Mean $I_{30}(\mathbf{m m} / \mathbf{h})$ & 3.6 & 2.5 & 3.3 & 3.0 \\
\hline Median $I_{30}(\mathbf{m m} / \mathbf{h})$ & 1.0 & 1.0 & 1.5 & 1.0 \\
\hline Maximum $I_{30}(\mathrm{~mm} / \mathrm{h})$ & 89 & 28 & 35 & 60 \\
\hline & \multicolumn{4}{|c|}{ Number of rainstorm events } \\
\hline $0.5<\mathbf{I}_{30}(\mathrm{~mm} / \mathrm{h})<2$ & 71 & 51 & 36 & 53 \\
\hline $2<\mathrm{I}_{30}(\mathrm{~mm} / \mathrm{h})<4$ & 20 & 10 & 11 & 6 \\
\hline $4<\mathrm{I}_{30}(\mathrm{~mm} / \mathrm{h})<6$ & 7 & 8 & 6 & 9 \\
\hline $6<\mathrm{I}_{30}(\mathrm{~mm} / \mathrm{h})<8$ & 5 & 4 & 1 & 5 \\
\hline $8<\mathrm{I}_{30}(\mathrm{~mm} / \mathrm{h})<10$ & 4 & 4 & 1 & 1 \\
\hline $\mathrm{I}_{30}(\mathrm{~mm} / \mathrm{h})>10$ & 9 & 2 & 6 & 4 \\
\hline
\end{tabular}




\section{Section 3-RUNOFF}

\section{Methods}

Stream gages with satellite telemetry were installed near the mouths of Buffalo and Spring Creeks in 1997 (fig. 1.1). Standard bubble gages (Accubar interfaced with Sutron 8210 DCP) were operated on a seasonal basis from about March to November of each year (USGS, 1997, 1998,1999 , and 2000). Stage data were collected every 15 minutes except when a preset stage threshold was exceeded and then data were collected every 5 minutes. The gage on Buffalo Creek was about $600 \mathrm{~m}$ upstream from the mouth, and the average slope of the channel below the gage was about 0.01 . Channel cross-sections at this gage changed frequently in response to flows from summer rainfall events, which transported sediment into and out of the reach. The gage on Spring Creek was about $1,500 \mathrm{~m}$ upstream from the mouth in a narrow (10 $\mathrm{m}$ wide) and stable bedrock channel with an average slope of about 0.04 . Little sediment was deposited or eroded from this reach, but during some flood events, moving cobbles and boulders damaged the gage orifice and no hydrographs were recorded. Indirect discharge measurements were made after these events in addition to the standard discharge measurements made throughout the gaging season (tables 3.1 and 3.2). Additional discharge measurements were made at the mouth of Spring Creek using a wooden Parshall flume (Grant, 1991). After the flume was destroyed in 1997 by a flood, measurements were made using Price-AA current meters, or surface floats when the water was too shallow for current meters. Surface velocities were converted to depth-averaged velocity by multiplying by 0.86 (Rantz and others, 1982).

Peak discharges following rainfall events were determined from the recorded hydrograph as the maximum value above the discharge preceding the event. Some days had more than one event (table 3.3). The corresponding 30-minute rainfall intensity, $I_{30}$, was also measured for each event at the two rain gages in the Spring Creek watershed. These two values of $\mathrm{I}_{30}$ were averaged and are reported in table 3.3 along with the unit-area peak discharge estimates. Some rainfall events created floods, which were defined as flows with peak discharges greater than 10 times the baseflow for June, July, and August 1997 and $1998\left(0.7\right.$ and $0.07 \mathrm{~m}^{3} / \mathrm{s}$, table 1.1) or where the average $I_{30}$ was greater than $10 \mathrm{~mm} / \mathrm{h}$. The unit-area peak discharge for these post-fire floods was calculated by dividing the peak discharge by the burned area for each watershed (table 1.1), which assumes the unburned area contributes a negligible amount to the flood. The assumption seems justified for Spring Creek, which had 79 percent of the watershed burned, but perhaps not for Buffalo Creek (79 percent was unburned). However, flood hydrographs for Buffalo Creek indicated only one major peak in discharge and no later peaks, which may have indicated significant runoff from the unburned part of the watershed. Post-fire floods are listed in table 3.4 along with the $\mathrm{I}_{30}$ values for both Buffalo and Spring Creeks. Often, rainfall events created floods on Buffalo Creek but not on Spring Creek, and vice versa. For example, see 2 August and 26 August 1997. However, data are listed for both watersheds, even though the corresponding event in the other watershed did not meet the criterion for a flood.

\section{$\underline{\text { Results }}$}

\section{Discharge Rating Curve}

The discharge rating curve for these steep channels can be modeled as critical flow. For critical flow, the cross-sectional mean velocity is given by 


$$
v=(g h)^{\frac{1}{2}}=\left(g \frac{A}{w}\right)^{\frac{1}{2}}
$$

where $g$ is the acceleration of gravity, $A$ is the cross-sectional area, $h$ is the mean depth above the bed, and $w$ is the top width. Discharge for this critical flow model is then given by

$$
Q=\left(g \frac{A^{3}}{w}\right)^{\frac{1}{2}} .
$$

Discharges predicted by the critical flow model are plotted against measured discharges for both Buffalo and Spring Creeks in figure 3.1. Discharges can be predicted in Spring Creek as a function of mean depth by using the cross-sectional area and top width for the cross section at the gaging station (table 3.5). Measured discharges in Spring Creek fit the critical-flow model better than discharges measured in Buffalo Creek. The slope of the regression line between the measured discharge and discharge predicted by the critical flow model should be 1.00 for perfect

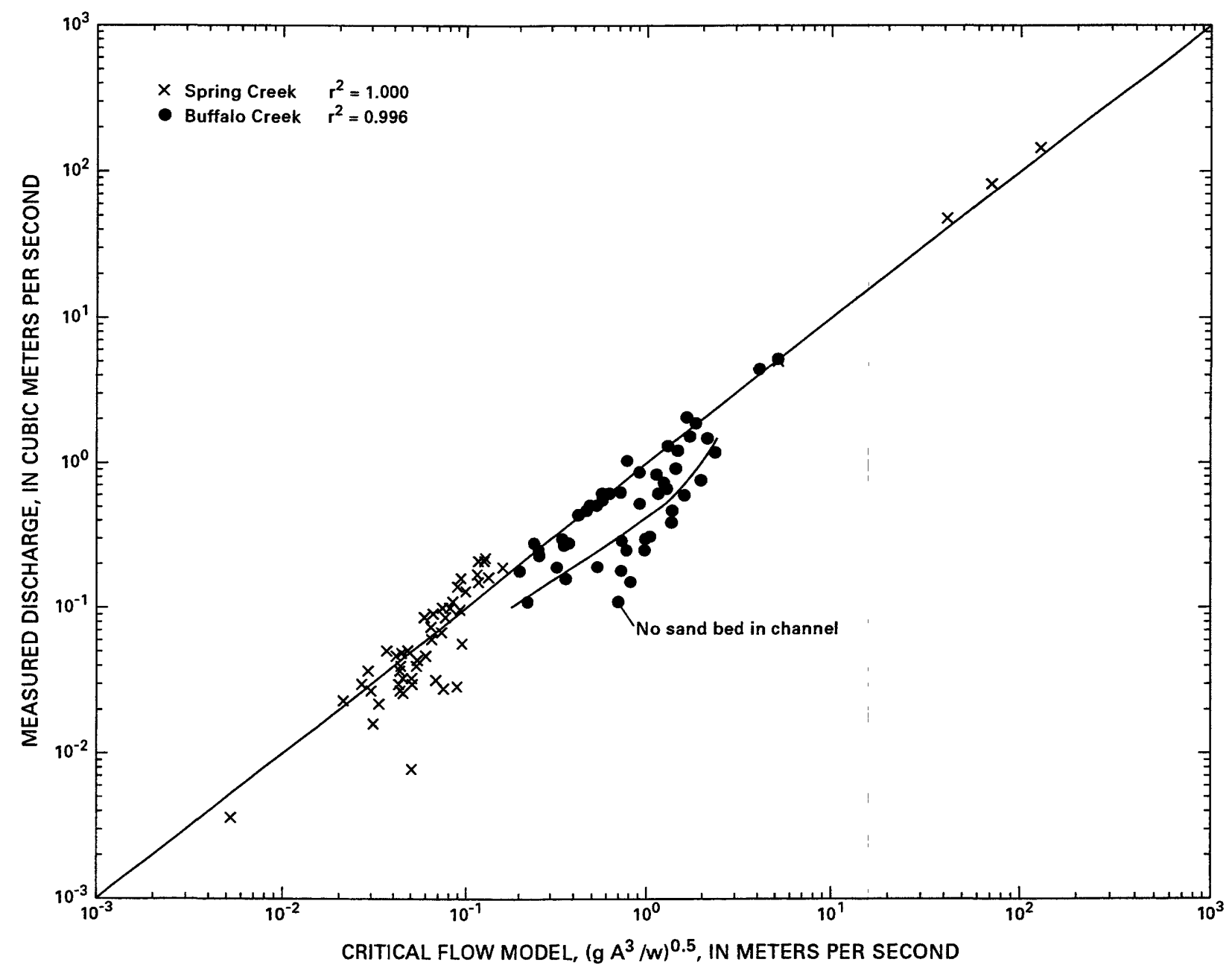

Figure 3.1. Measured discharges in Buffalo and Spring Creeks compared with those predicted by the critical flow model $Q=\left(g \cdot A^{3} / w\right)^{0.5}$, where $\mathrm{g}=9.8 \mathrm{~m} / \mathrm{s}^{2}, \mathrm{~A}=\operatorname{cross}$ sectional area $\left(\mathrm{m}^{2}\right)$, and $\mathrm{w}=$ top width $(\mathrm{m})$. 
agreement. For Spring Creek, the slope is $1.15 \pm 0.01$ ( \pm 95 percent confidence limits), and for Buffalo Creek, the slope is $0.88 \pm 0.02$. The agreement is good because the data span five orders of magnitude and the large discharges have a large "influence" in the linear regression, while most of the measurements at low flow have more variability, which is exaggerated by plotting the data on a $\log -\log$ plot (fig. 3.1). However, some of the variability in the Buffalo Creek data is because two different bed regimes are present. One regime was when the channel was filled with sand after a flood event and the other regime was when essentially no sand was present (below the broken line in fig. 3.1) after a prolonged period of steady flow that eroded and transported the sand out of the channel and into the North Fork of the South Platte River.

\section{Rainfall--Runoff Relation}

In Spring Creek after the wildfire, the runoff (expressed as unit-area peak discharge) was related to the rainfall intensity. This relation appears to have a change in slope at about $\mathrm{I}_{30}=10$ $\mathrm{mm} / \mathrm{h}$ (fig. 3.2). This change may be caused by relative storm size, threshold intensity, or both. One possibility is that some of the discharge measurements made at the mouth of Spring Creek may represent the effect of rainstorms smaller in size than the Spring Creek watershed and, thus, the storms may have affected only a few sub watersheds. The unit-area peak discharge calculated using the drainage area of the Spring Creek watershed would, therefore, be less than the actual unit-area peak discharge. The effect may be greatest for low intensity storms, if low intensities correspond to smaller-sized rainstorms; unfortunately, no research has been done to establish this possible correspondence (Nolan Doesken, oral commun., 2000). Another possible explanation is that rainfall intensities greater than $10 \mathrm{~mm} / \mathrm{h}$ may exceed the average infiltration rate of the watershed such that runoff is dominated by sheet flow that produces floods. A similar threshold intensity was reported by Mackay and Cornish (1982) for watersheds on the Bega Batholith in New South Wales. In the Spring Creek watershed, several events in 1999 and 2000 corresponding to intensities between 10 and $30 \mathrm{~mm} / \mathrm{h}$ (fig. 3.2) produced unit-area peak discharges less than most of those in 1997, which suggests that the threshold of critical intensity may be increasing and might explain the decrease in extreme floods in 1999 and 2000 (table 3.4). For example, in 1997, an $\mathrm{I}_{30}$ of about $19 \mathrm{~mm} / \mathrm{h}$ produced a unit-area peak discharge of $0.31 \mathrm{~m}^{3} / \mathrm{s} / \mathrm{km}^{2}$, whereas in 2000 a similar rainfall intensity produced a unit-area peak discharge of only $0.0031 \mathrm{~m}^{3} / \mathrm{s} / \mathrm{km}^{2}$, corresponding to a 100 -fold decrease. Also in 1997, an $\mathrm{I}_{30}$ of about $50 \mathrm{~mm} / \mathrm{h}$ produced a unit-area peak discharge of $6.6 \mathrm{~m}^{3} / \mathrm{s} / \mathrm{km}^{2}$, whereas in 2000 a comparable rainfall intensity produced a unitarea peak discharge of only $0.11 \mathrm{~m}^{3} / \mathrm{s} / \mathrm{km}^{2}$, or a 60 -fold decrease. Some data from the Barrett Fire (Sinclair and Hamilton, 1955) and Johnstone Peak Fire (Krammes and Rice, 1963; Doehring, 1968 ) in the San Grabriel Mountains of Southern California are also plotted in figure 3.2. Terrain and bedrock in these mountains are similar to Buffalo and Spring Creeks, steep and granitic, but the vegetation is predominately chaparral. 


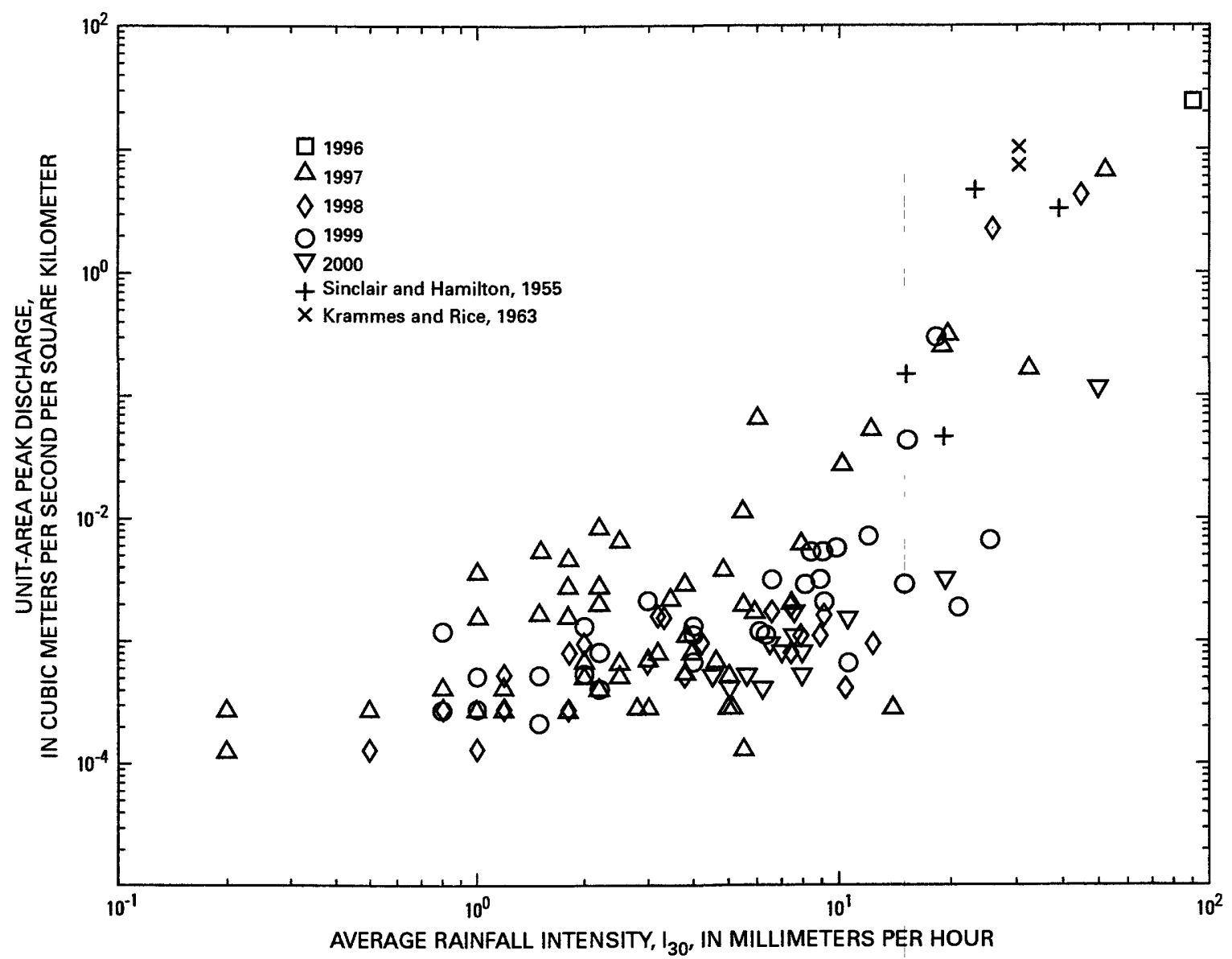

Figure 3.2. Relation between unit-area peak discharge and the 30-minute maximum rainfall intensity, $\mathrm{I}_{30}$. Discharges were measured at the gage at the mouth of the Spring Creek watershed, and the rainfall intensity was the average of the $\mathrm{I}_{30}$-intensities at the Scraggy Ranch gage and at the Spring Creek gage. 


\section{Table 3.1. Summary of discharge measurements for Buffalo Creek, 1997-2000}

[No., number of the discharge measurement reported on the U. S. Geological Survey's form 9-207 for the gage site about $600 \mathrm{~m}$ upstream from the mouth; other measurements were made using Price-AA current meter at 0.6 depth and various types of surface floats and multiplying the surface velocity by 0.86 to estimate the depth-averaged mean velocity (Rantz and others, 1982); mean velocity is discharge/area; mean depth is area/width; SA, slope area indirect method to determine peak discharge; SC, specific conductance (microsiemens/centimeter); MDT, Mountain Daylight Time; MST, Mountain Standard Time; m, meter; $\mathrm{m}^{2}$, square meter; $\mathrm{m} / \mathrm{s}$, meter per second; $\mathrm{m}^{3} / \mathrm{s}$, cubic meter per second]

\begin{tabular}{|c|c|c|c|c|c|c|c|c|c|}
\hline No. & Date & $\begin{array}{c}\text { Width } \\
\text { (m) }\end{array}$ & $\begin{array}{c}\text { Mean } \\
\text { depth } \\
(\mathbf{m})\end{array}$ & $\begin{array}{l}\text { Area } \\
\left(\mathrm{m}^{2}\right)\end{array}$ & Slope & $\begin{array}{l}\text { Mean } \\
\text { velocity } \\
(\mathrm{m} / \mathrm{s})\end{array}$ & $\begin{array}{l}\text { Gage } \\
\text { height } \\
\text { (feet) }\end{array}$ & $\begin{array}{c}\text { Discharge } \\
\left(\mathrm{m}^{3} / \mathrm{s}\right)\end{array}$ & Comments \\
\hline \multicolumn{10}{|c|}{1997} \\
\hline & $3-20-97$ & 4.1 & 0.063 & 0.26 & 0.0093 & 0.68 & $\begin{array}{l}\text { not } \\
\text { measured }\end{array}$ & 0.18 & $\begin{array}{l}\text { Measured before gage was } \\
\text { installed; used slope from June } \\
1997 \text { survey; at } 79 \text { m upstream from } \\
\text { the mouth. }\end{array}$ \\
\hline \multirow[t]{4}{*}{1} & $5-22-97$ & 6.2 & 0.095 & 0.59 & -- & 0.98 & 4.20 & 0.56 & - \\
\hline & $7-01-97$ & 8.4 & 0.074 & 0.62 & 0.0093 & 0.82 & 5.0 & 0.51 & $\begin{array}{l}\text { Used slope from June } 1997 \text { survey; } \\
\text { at } 79 \mathrm{~m} \text { upstream from the mouth; } \\
\text { measured near noon. }\end{array}$ \\
\hline & $7-14-97$ & 9.3 & 0.053 & 0.49 & 0.010 & 0.55 & 4.68 & 0.27 & $\begin{array}{l}\text { Surface velocity measurement at } 79 \\
\text { m upstream from the mouth. }\end{array}$ \\
\hline & $7-14-97$ & 5.6 & 0.064 & 0.36 & 0.011 & 0.69 & 4.68 & 0.25 & $\begin{array}{l}\text { Surface velocity measurement at } \\
480 \mathrm{~m} \text { upstream from the mouth. }\end{array}$ \\
\hline 2 & $7-15-97$ & 4.1 & 0.071 & 0.29 & - & 0.22 & 4.65 & 0.28 & -- \\
\hline \multirow[t]{2}{*}{ SA } & $7-29-97$ & 12.9 & 0.91 & 11.7 & 0.016 & 2.6 & 8.4 & 30.5 & Indirect measurement. \\
\hline & $8-19-97$ & 7.3 & 0.070 & 0.51 & 0.011 & 0.86 & 5.14 & 0.44 & $\begin{array}{l}\text { Measured at } 72 \mathrm{~m} \text { upstream from } \\
\text { the mouth. }\end{array}$ \\
\hline \multirow[t]{2}{*}{3} & $8-27-97$ & 4.9 & 0.100 & 0.49 & -- & 1.04 & 4.94 & 0.51 & - \\
\hline & $9-01-97$ & 5.0 & 0.096 & 0.48 & 0.013 & 0.98 & 4.8 & 0.47 & $\begin{array}{l}\text { Measured at } 90 \mathrm{~m} \text { upstream from } \\
\text { the mouth; } 1330-1354 \mathrm{MDT} \text {. }\end{array}$ \\
\hline \multirow[t]{5}{*}{4} & $10-08-97$ & 3.2 & 0.088 & 0.28 & -- & 0.85 & 4.61 & 0.23 & $\mathrm{SC}=166$ \\
\hline & $11-03-97$ & 6.3 & 0.094 & 0.59 & 0.015 & 1.1 & 5.18 & 0.62 & $\begin{array}{l}\text { Measured at } 79 \text { m upstream from } \\
\text { the mouth; } 1128-1156 \mathrm{MST} \text {. }\end{array}$ \\
\hline & $11-03-97$ & 8.0 & 0.085 & 0.68 & 0.013 & 0.91 & 5.13 & 0.62 & $\begin{array}{l}\text { Measured at } 79 \mathrm{~m} \text { upstream from } \\
\text { the mouth; } 1353-1430 \text { MST. }\end{array}$ \\
\hline & $11-07-97$ & 7.5 & 0.11 & 0.86 & 0.014 & 1.0 & 5.17 & 0.87 & -- \\
\hline & \multicolumn{9}{|c|}{1998} \\
\hline \multirow[t]{2}{*}{5} & $4-27-98$ & 10.2 & 0.12 & 1.21 & - & 1.08 & 5.92 & 1.31 & $\mathrm{SC}=95$ \\
\hline & $5-09-98$ & 8.0 & 0.16 & 1.3 & 0.015 & 1.6 & 5.89 & 2.1 & $\begin{array}{l}\text { Measured at } 480 \mathrm{~m} \text { upstream from } \\
\text { the mouth. }\end{array}$ \\
\hline 6 & $5-11-98$ & 9.4 & 0.15 & 1.41 & -- & 1.09 & 5.70 & 1.53 & $\mathrm{SC}=84$ \\
\hline 7 & $5-20-98$ & 6.5 & 0.20 & 1.31 & - & 1.43 & 4.93 & 1.88 & -- \\
\hline 8 & $6-03-98$ & 5.5 & 0.25 & 1.36 & -- & 1.09 & 4.03 & 1.48 & $\mathrm{SC}=71$ \\
\hline \multirow[t]{2}{*}{9} & $6-23-98$ & 4.9 & 0.21 & 1.01 & -- & 0.91 & 3.76 & 0.92 & $\mathrm{SC}=62$ \\
\hline & $7-22-98$ & 6.9 & 0.14 & 0.98 & 0.015 & 0.63 & 3.76 & 0.62 & $\begin{array}{l}\text { Measured at } 190 \mathrm{~m} \text { upstream from } \\
\text { the mouth; gravel bed with almost } \\
\text { no sand. }\end{array}$ \\
\hline 10 & $7-24-98$ & 4.6 & 0.20 & 0.92 & -- & 0.73 & 3.62 & 0.67 & Lowered orifice; $\mathrm{SC}=91$. \\
\hline
\end{tabular}


Table 3.1. (Continued) Summary of discharge measurements for Buffalo Creek, 1997-2000

\begin{tabular}{|c|c|c|c|c|c|c|c|c|c|}
\hline No. & Date & $\begin{array}{l}\text { Width } \\
\text { (m) }\end{array}$ & $\begin{array}{l}\text { Mean } \\
\text { depth } \\
\text { (m) }\end{array}$ & $\begin{array}{l}\text { Area } \\
\left(\mathrm{m}^{2}\right)\end{array}$ & Slope & $\begin{array}{l}\text { Mean } \\
\text { velocity } \\
(\mathrm{m} / \mathrm{s})\end{array}$ & $\begin{array}{l}\text { Gage } \\
\text { height } \\
\text { (feet) }\end{array}$ & $\begin{array}{l}\text { Discharge } \\
\left(\mathrm{m}^{3} / \mathrm{s}\right)\end{array}$ & Comments \\
\hline & $8-07-98$ & 8.3 & 0.096 & 0.80 & 0.014 & 1.3 & 5.57 & 1.0 & $\begin{array}{l}\text { Measurement was at } 480 \mathrm{~m} \\
\text { upstream from the mouth. }\end{array}$ \\
\hline 11 & $8-27-98$ & 4.8 & 0.13 & 0.63 & - & 0.99 & 4.85 & 0.63 & -- \\
\hline \multirow[t]{2}{*}{12} & $10-08-98$ & 3.0 & 0.12 & 0.35 & - & 0.79 & 3.80 & 0.28 & $\mathrm{SC}=157$ \\
\hline & $10-17-98$ & 2.7 & 0.12 & 0.32 & 0.0073 & 0.94 & 3.76 & 0.30 & $\begin{array}{l}\text { Surface velocity was measured } \\
\text { over a distance of } 7 \mathrm{~m} \text { at } 480 \mathrm{~m} \\
\text { upstream from the mouth. }\end{array}$ \\
\hline \multirow[t]{2}{*}{13} & $11-24-98$ & 2.8 & 0.11 & 0.31 & -- & 0.62 & 3.65 & 0.19 & $\mathrm{SC}=160$ \\
\hline & \multicolumn{9}{|c|}{1999} \\
\hline 14 & $3-24-99$ & 2.1 & 0.10 & 0.22 & - & 0.50 & 3.49 & 0.11 & -- \\
\hline 15 & $4-21-99$ & 2.7 & 0.12 & 0.33 & - & 0.48 & 3.46 & 0.16 & -- \\
\hline 16 & $5-05-99$ & 7.2 & 0.16 & 1.17 & - & 1.05 & 3.98 & 1.22 & $\mathrm{SC}=90$ \\
\hline 17 & $5-19-99$ & 3.6 & 0.22 & 0.78 & - & 1.08 & 3.98 & 0.84 & $\mathrm{SC}=89$ \\
\hline \multirow[t]{2}{*}{18} & $5-25-99$ & 11.3 & 0.24 & 2.68 & - & 1.66 & 5.66 & 4.45 & $\mathrm{SC}=60$ \\
\hline & $5-26-99$ & 13.7 & 0.24 & 3.33 & 0.015 & 1.6 & 5.51 & 5.20 & $\begin{array}{l}\text { Surface velocity was measured at } \\
190 \mathrm{~m} \text { upstream from the mouth. }\end{array}$ \\
\hline 19 & $6-09-99$ & 5.5 & 0.26 & 1.45 & - & 0.82 & 3.69 & 1.19 & $\mathrm{SC}=82$ \\
\hline 20 & $7-01-99$ & 6.1 & 0.22 & 1.34 & - & 0.57 & 3.30 & 0.76 & $\mathrm{SC}=97$ \\
\hline 21 & $7-20-99$ & 3.3 & 0.26 & 0.86 & - & 0.55 & 3.12 & 0.47 & - \\
\hline 22 & $8-17-99$ & 6.4 & 0.16 & 1.00 & -- & 0.73 & 3.52 & 0.73 & $\mathrm{SC}=103$ \\
\hline 23 & $9-02-99$ & 5.8 & 0.14 & 0.79 & -- & 0.65 & 3.35 & 0.52 & $\mathrm{SC}=129$ \\
\hline 24 & $10-13-99$ & 2.9 & 0.19 & 0.56 & -- & 0.46 & 3.18 & 0.25 & $S C=142$ \\
\hline \multicolumn{10}{|c|}{2000} \\
\hline 25 & $3-27-00$ & 2.4 & 0.17 & 0.41 & -- & 0.48 & 3.07 & 0.19 & $\mathrm{SC}=140$ \\
\hline 26 & $4-18-00$ & 2.8 & 0.24 & 0.68 & - & 0.46 & 3.16 & 0.31 & $\mathrm{SC}=111$ \\
\hline 27 & $4-20-00$ & 2.9 & 0.23 & 0.66 & -- & 0.46 & 3.18 & 0.30 & - \\
\hline \multirow[t]{2}{*}{28} & $5-16-00$ & 2.8 & 0.29 & 0.81 & -- & 0.48 & 3.16 & 0.39 & $\mathrm{SC}=87$ \\
\hline & $6-04-00$ & 4.0 & 0.15 & 0.60 & 0.0026 & 0.48 & 3.10 & 0.29 & -- \\
\hline 29 & $6-22-00$ & 2.5 & 0.20 & 0.51 & -- & 0.34 & 2.93 & 0.18 & $\mathrm{SC}=110$ \\
\hline 30 & $6-28-00$ & 2.2 & 0.27 & 0.60 & -- & 0.42 & 3.44 & 0.25 & $\mathrm{SC}=102$ \\
\hline 31 & $8-03-00$ & 4.3 & 0.24 & 1.04 & - & 0.58 & 3.76 & 0.60 & $\mathrm{SC}=71$ \\
\hline 32 & $8-31-00$ & 2.6 & 0.22 & 0.56 & - & 0.27 & 3.35 & 0.15 & $\mathrm{SC}=140$ \\
\hline 33 & $10-10-00$ & 2.4 & 0.20 & 0.49 & -- & 0.23 & 3.38 & 0.11 & $\mathrm{SC}=154$ \\
\hline
\end{tabular}




\section{Table 3.2. Summary of discharge measurements for Spring Creek, 1997-2000}

[No., number of the discharge measurement reported on the U. S. Geological Survey's form 9-207 for the gage site about $1500 \mathrm{~m}$ upstream from the mouth; other measurements were made using Price-AA current meter at 0.6 depth and various types of surface floats and multiplying the surface velocity by 0.86 to estimate the depth-averaged mean velocity (Rantz and others, 1982); $\mathrm{nm}$, not measured; mean depth is area/ width; mean velocity is discharge/area; SA, slope area indirect method to determine peak discharge; SC, specific conductance (microsiemens/centimeter); MDT, Mountain Daylight Time; MST, Mountain Standard Time; $\mathrm{m}$, meter; $\mathrm{m}^{2}$, square meter; $\mathrm{m} / \mathrm{s}$, meter per second; $\mathrm{m}^{3} / \mathrm{s}$, cubic meter per second]

\begin{tabular}{|c|c|c|c|c|c|c|c|c|c|}
\hline No. & Date & $\begin{array}{l}\text { Width } \\
\text { (m) }\end{array}$ & $\begin{array}{c}\text { Mean } \\
\text { depth } \\
(m)\end{array}$ & $\begin{array}{l}\text { Area } \\
\left(m^{2}\right)\end{array}$ & Slope & $\begin{array}{l}\text { Mean } \\
\text { velocity } \\
(\mathrm{m} / \mathrm{s})\end{array}$ & $\begin{array}{c}\text { Gage } \\
\text { height } \\
\text { (feet) }\end{array}$ & $\begin{array}{c}\text { Discharge } \\
\left(\mathrm{m}^{3} / \mathrm{s}\right)\end{array}$ & Comments \\
\hline \multicolumn{10}{|c|}{1997} \\
\hline 1 & $4-21-97$ & 1.00 & 0.045 & 0.045 & -- & 0.60 & 4.02 & 0.027 & Installed gage; $\mathrm{SC}=209$ \\
\hline 2 & $5-19-97$ & 0.76 & 0.050 & 0.038 & - & 0.79 & 4.05 & 0.030 & - \\
\hline 3 & $7-15-97$ & 0.91 & 0.061 & 0.056 & - & 0.48 & 3.96 & 0.027 & -- \\
\hline \multirow[t]{4}{*}{4} & $8-26-97$ & 1.22 & 0.045 & 0.055 & - & 0.93 & 4.20 & 0.051 & - \\
\hline & $6-28-97$ & 0.61 & 0.064 & 0.039 & 0.04 & 0.41 & 4.75 & 0.016 & $\begin{array}{l}\text { Parshall flume at mouth; } 1315-1415 \\
\text { MDT. }\end{array}$ \\
\hline & $7-02-97$ & 0.61 & 0.034 & 0.021 & 0.04 & 0.37 & 4.07 & 0.0078 & $\begin{array}{l}\text { Parshall flume at mouth; } 1100-1300 \\
\text { MDT. }\end{array}$ \\
\hline & $7-11-97$ & 0.61 & 0.021 & 0.013 & 0.026 & 0.28 & 4.23 & 0.0036 & $\begin{array}{l}\text { Parshall flume at mouth; } 1735-1825 \\
\text { MDT. }\end{array}$ \\
\hline \multirow[t]{3}{*}{$\mathrm{SA}$} & $7-29-97$ & 8.7 & 0.33 & 2.9 & 0.041 & 1.7 & 5.41 & 5.0 & $\begin{array}{l}\text { Used Cowan's (1956) method of } \\
\text { estimating Manning's } n=0.055 \text {. }\end{array}$ \\
\hline & 8-03-97 & 0.61 & 0.067 & 0.041 & 0.030 & 0.54 & 4.20 & 0.022 & $\begin{array}{l}\text { Parshall flume at mouth; } 1400-1500 \\
\text { MDT. }\end{array}$ \\
\hline & $8-05-97$ & 0.61 & 0.089 & 0.054 & 0.032 & 0.63 & 4.30 & 0.034 & $\begin{array}{l}\text { Parshall flume at mouth; 1900-1944 } \\
\text { MDT. }\end{array}$ \\
\hline \multirow[t]{4}{*}{ SA } & $8-31-97$ & - & - & - & -- & -- & 13.4 & 180 & USGS Colorado District. \\
\hline & $8-31-97$ & 12 & 2.2 & 27 & 0.04 & 5.4 & 13.4 & 140 & $\begin{array}{l}\text { Estimated slope was } 0.04 \text {. Used } \\
\text { Cowan's (1956) method for esti- } \\
\text { mating Manning's } n=0.055 \text {. }\end{array}$ \\
\hline & $9-15-97$ & 1.40 & 0.046 & 0.065 & 0.032 & 0.61 & 4.42 & 0.040 & $\begin{array}{l}\text { Surface velocity was measured at } \\
13 \text { verticals at mouth at } 1130 \\
\text { MDT. }\end{array}$ \\
\hline & $10-08-97$ & 0.85 & 0.041 & 0.035 & 0.027 & 0.66 & 4.11 & 0.023 & $\begin{array}{l}\text { Surface velocity was measured at } 7 \\
\text { verticals at mouth. }\end{array}$ \\
\hline 5 & $10-08-97$ & 1.07 & 0.042 & 0.045 & - & 0.82 & 4.11 & 0.037 & $\mathrm{SC}=195$ \\
\hline \multicolumn{10}{|c|}{1998} \\
\hline 6 & $3-24-98$ & 2.28 & 0.052 & 0.118 & -- & 0.93 & 4.44 & 0.11 & $\mathrm{SC}=210$ \\
\hline 7 & $3-26-98$ & 2.53 & 0.060 & 0.151 & -- & 1.14 & 4.34 & 0.17 & -- \\
\hline \multirow[t]{3}{*}{8} & $4-27-98$ & 2.13 & 0.084 & 0.178 & - & 1.05 & 4.34 & 0.19 & $\mathrm{SC}=175$ \\
\hline & $5-03-98$ & 3.0 & 0.056 & 0.17 & - & 1.2 & 4.30 & 0.21 & $\begin{array}{l}\text { Surface velocity was measured at } \\
\text { about } 1500 \text { MDT. }\end{array}$ \\
\hline & $5-17-98$ & 2.4 & 0.063 & 0.15 & -- & 1.0 & 4.20 & 0.15 & $\begin{array}{l}\text { Surface velocity was measured at } \\
\text { gage at about } 1510 \mathrm{MDT} \text {. }\end{array}$ \\
\hline
\end{tabular}


Table 3.2. (Continued) Summary of discharge measurements for Spring Creek, 1997-2000

\begin{tabular}{|c|c|c|c|c|c|c|c|c|c|}
\hline No. & Date & $\begin{array}{l}\text { Width } \\
\text { (m) }\end{array}$ & $\begin{array}{c}\text { Mean } \\
\text { depth } \\
(\mathbf{m})\end{array}$ & $\begin{array}{l}\text { Area } \\
\left(\mathrm{m}^{2}\right)\end{array}$ & Slope & $\begin{array}{l}\text { Mean } \\
\text { velocity } \\
(\mathrm{m} / \mathrm{s})\end{array}$ & $\begin{array}{l}\text { Gage } \\
\text { height } \\
\text { (feet) }\end{array}$ & $\begin{array}{c}\text { Discharge } \\
\left(\mathrm{m}^{3} / \mathrm{s}\right)\end{array}$ & Comments \\
\hline & $5-21-98$ & 2.0 & 0.063 & 0.126 & -- & 1.0 & 4.2 & 0.13 & $\begin{array}{l}\text { Surface velocity was measured at } \\
\text { gage at about } 1200 \mathrm{MDT} \text {. }\end{array}$ \\
\hline & $5-21-98$ & 2.7 & 0.050 & 0.134 & 0.030 & 1.2 & 4.2 & 0.16 & $\begin{array}{l}\text { Surface velocity was measured in a } \\
\text { flume constructed of rocks at the } \\
\text { mouth at about } 1300 \mathrm{MDT} \text {. }\end{array}$ \\
\hline \multirow[t]{3}{*}{9} & $6-08-98$ & 2.04 & 0.052 & 0.107 & -- & 0.80 & 4.09 & 0.086 & -- \\
\hline & $6-26-98$ & 1.7 & 0.054 & 0.091 & 0.023 & 1.0 & 3.92 & 0.091 & $\begin{array}{l}\text { Surface velocity was measured at } \\
\text { gage at } 1223 \mathrm{MDT} \text {. }\end{array}$ \\
\hline & $6-26-98$ & 2.0 & 0.047 & 0.094 & 0.025 & 0.79 & 3.90 & 0.074 & $\begin{array}{l}\text { Surface velocity was measured in a } \\
\text { flume constructed of rocks at the } \\
\text { mouth at } 1725 \text { MDT. }\end{array}$ \\
\hline $\mathrm{SA}$ & $7-09-98$ & 10.5 & 1.2 & 12.2 & 0.04 & 3.9 & 8.75 & 48 & $\begin{array}{l}\text { Used Cowan's (1956) method of } \\
\text { estimating Manning's } \mathrm{n}=0.055 \text {. } \\
\text { USGS Colorado District indirect } \\
\text { measurement was } 58 \mathrm{~m}^{3} \mathrm{~s}^{-1} \text {. }\end{array}$ \\
\hline 10 & $7-14-98$ & 1.34 & 0.058 & 0.078 & - & 1.10 & 4.43 & 0.086 & - \\
\hline \multirow[t]{2}{*}{$\mathrm{SA}$} & $7-31-98$ & 11.1 & 1.6 & 17.8 & 0.04 & 4.6 & 10.4 & 82 & $\begin{array}{l}\text { High water was estimated to be } 9 \\
\text { July high water plus } 0.5 \mathrm{~m} \text {. Used } \\
\text { Cowan's }(1956) \text { method of esti- } \\
\text { mating Manning's } \mathrm{n}=0.055 \text {; }\end{array}$ \\
\hline & $8-05-98$ & 2.7 & 0.048 & 0.130 & 0.034 & 1.1 & 4.67 & 0.14 & $\begin{array}{l}\text { Surface velocity was measured } 100 \\
\mathrm{~m} \text { below gage at } 1805 \mathrm{MDT} .\end{array}$ \\
\hline \multirow[t]{2}{*}{11} & $9-11-98$ & 1.49 & 0.075 & 0.111 & -- & 0.51 & $\mathrm{~nm}$ & 0.057 & -- \\
\hline & $10-21-98$ & 1.3 & 0.068 & 0.089 & -- & 0.76 & $\mathrm{~nm}$ & 0.068 & $\begin{array}{l}\text { Surface velocity was measured } 21 \\
\text { m upstream from gage at } 0925 \\
\text { MDT and water level was } 0.03 \mathrm{~m} \\
\text { below gage orifice. }\end{array}$ \\
\hline \multirow[t]{3}{*}{12} & $11-24-98$ & 1.2 & 0.053 & 0.063 & - & 0.52 & $\mathrm{~nm}$ & 0.033 & $\mathrm{SC}=202$ \\
\hline & & & & & & 1999 & & & \\
\hline & $2-24-99$ & 1.3 & 0.049 & 0.064 & 0.023 & 0.77 & $\mathrm{~nm}$ & 0.049 & $\begin{array}{l}\text { Used pieces of ice as floats over a } 3 \\
\text { m reach. }\end{array}$ \\
\hline 13 & $3-23-99$ & 0.94 & 0.096 & 0.091 & -- & 0.32 & 4.30 & 0.029 & Sandbags put in channel at gage. \\
\hline 14 & $4-21-99$ & 0.91 & 0.068 & 0.062 & - & 0.48 & 4.31 & 0.030 & $\mathrm{SC}=207$ \\
\hline \multirow[t]{2}{*}{15} & $5-05-99$ & 2.35 & 0.069 & 0.163 & -- & 1.00 & 4.48 & 0.162 & \\
\hline & $5-05-99$ & 2.0 & 0.075 & 0.15 & $\sim 0.025$ & 1.8 & 4.42 & 0.22 & $\begin{array}{l}\text { Used surface floats to measure } \\
\text { velocity over a } 10 \mathrm{~m} \text { reach at } 30 \\
\mathrm{~m} \text { above the gage at } 1745 \mathrm{MDT} \text {. }\end{array}$ \\
\hline
\end{tabular}


Table 3.2. (Continued) Summary of discharge measurements for Spring Creek, 1997-2000

\begin{tabular}{|c|c|c|c|c|c|c|c|c|c|}
\hline No. & Date & $\begin{array}{l}\text { Width } \\
\text { (m) }\end{array}$ & $\begin{array}{l}\text { Mean } \\
\text { depth } \\
(\mathbf{m})\end{array}$ & $\begin{array}{l}\text { Area } \\
\left(\mathbf{m}^{2}\right)\end{array}$ & Slope & $\begin{array}{l}\text { Mean } \\
\text { velocity } \\
(\mathbf{m} / \mathbf{s})\end{array}$ & $\begin{array}{c}\text { Gage } \\
\text { height } \\
\text { (feet) }\end{array}$ & $\begin{array}{l}\text { Discharge } \\
\left(\mathrm{m}^{3} / \mathrm{s}\right)\end{array}$ & Comments \\
\hline & $5-15-99$ & 1.40 & 0.065 & 0.092 & 0.027 & 1.1 & 4.09 & 0.10 & $\begin{array}{l}\text { Measured velocity using surface } \\
\text { floats over a } 3 \mathrm{~m} \text { reach at the } \\
\text { mouth at } 1100 \mathrm{MDT} \text {. }\end{array}$ \\
\hline & $5-26-99$ & 2.0 & 0.070 & 0.141 & 0.034 & 1.5 & 4.27 & 0.21 & $\begin{array}{l}\text { Measured velocity using surface } \\
\text { floats over a } 3.6 \mathrm{~m} \text { reach at the } \\
\text { mouth at } 1545 \mathrm{MDT} \text {. }\end{array}$ \\
\hline 16 & 6-09-99 & 1.80 & 0.064 & 0.116 & -- & 0.84 & 4.18 & 0.097 & $S C=191$ \\
\hline 17 & $7-01-99$ & 1.34 & 0.059 & 0.079 & -- & 0.59 & 4.43 & 0.047 & $\begin{array}{l}\text { Pressure transducer was installed. } \\
\quad S C=200 \text {. }\end{array}$ \\
\hline 18 & $7-28-99$ & 1.16 & 0.068 & 0.079 & -- & 0.77 & 4.43 & 0.061 & $\mathrm{SC}=210$ \\
\hline 19 & $9-02-99$ & 2.16 & 0.052 & 0.113 & - & 0.88 & 4.34 & 0.100 & $\begin{array}{l}\text { Sand bags were added to the con- } \\
\text { trol. } S C=205 \text {. }\end{array}$ \\
\hline 20 & $10-13-99$ & 1.52 & 0.047 & 0.071 & -- & 0.72 & 4.26 & 0.051 & $\mathrm{SC}=210$ \\
\hline \multicolumn{10}{|c|}{2000} \\
\hline \multirow[t]{2}{*}{21} & $3-27-00$ & 0.94 & 0.069 & 0.065 & - & 0.62 & 4.33 & 0.040 & $\mathrm{SC}=204$ \\
\hline & $5-02-00$ & 0.95 & 0.058 & 0.055 & 0.026 & 0.85 & 4.42 & 0.047 & Mouth; 1315 MDT. \\
\hline 22 & $4-18-00$ & 1.10 & 0.063 & 0.069 & -- & 0.64 & 4.34 & 0.044 & $\mathrm{SC}=204$ \\
\hline 23 & $5-16-00$ & 1.22 & 0.050 & 0.061 & -- & 0.49 & 4.32 & 0.030 & $\mathrm{SC}=210$ \\
\hline 24 & $6-22-00$ & 1.19 & 0.053 & 0.063 & -- & 0.41 & 4.33 & 0.026 & $\mathrm{SC}=219$ \\
\hline 25 & $8-02-00$ & 0.76 & 0.093 & 0.071 & -- & 0.45 & 4.24 & 0.032 & $\mathrm{SC}=213$ \\
\hline 26 & $8-31-00$ & 1.07 & 0.079 & 0.085 & -- & 0.33 & 4.35 & 0.028 & $\mathrm{SC}=221$ \\
\hline 27 & $10-10-00$ & 1.07 & 0.055 & 0.059 & -- & 0.63 & 4.35 & 0.037 & $\mathrm{SC}=218$ \\
\hline
\end{tabular}


Table 3.3. Rainfall intensity and peak discharges for the Spring Creek watershed, 19972000

$\left[\mathrm{I}_{30}\right.$, maximum 30-minute rainfall intensity; na, not applicable; $\mathrm{mm} / \mathrm{h}$, millimeter per hour; $\mathrm{m}^{3} / \mathrm{s}$ cubic meter per second; $\mathrm{m}^{3} / \mathrm{s} / \mathrm{km}^{2}$, cubic meter per second per square kilometer]

\begin{tabular}{|c|c|c|c|c|c|c|c|c|c|c|c|}
\hline \multirow[b]{2}{*}{$\begin{array}{c}\text { Day } \\
\text { Month }\end{array}$} & \multicolumn{3}{|c|}{$\mathbf{I}_{30}(\mathrm{~mm} / \mathrm{h})$} & \multicolumn{2}{|c|}{ Peak discharge } & \multirow[b]{2}{*}{$\begin{array}{c}\text { Day } \\
\text { Month }\end{array}$} & \multicolumn{3}{|c|}{$\mathbf{I}_{\mathbf{3 0}}(\mathbf{m m} / \mathbf{h})$} & \multicolumn{2}{|c|}{ Peak discharge } \\
\hline & $\begin{array}{c}\text { Long } \\
\text { Scraggy } \\
\text { Ranch }\end{array}$ & $\begin{array}{l}\text { Spring } \\
\text { Creek } \\
\text { above } \\
\text { mouth }\end{array}$ & Average & $\begin{array}{l}\text { Above } \\
\text { back- } \\
\text { ground } \\
\left(\mathrm{m}^{3} / \mathrm{s}\right)\end{array}$ & $\begin{array}{c}\text { Per unit- } \\
\text { area } \\
\left(\mathrm{m}^{3} / \mathrm{s} /\right. \\
\left.\mathrm{km}^{2}\right)\end{array}$ & & $\begin{array}{c}\text { Long } \\
\text { Scraggy } \\
\text { Ranch }\end{array}$ & $\begin{array}{l}\text { Spring } \\
\text { Creek } \\
\text { above } \\
\text { mouth }\end{array}$ & Average & $\begin{array}{l}\text { Above } \\
\text { back- } \\
\text { ground } \\
\left(\mathrm{m}^{3} / \mathrm{s}\right)\end{array}$ & $\begin{array}{c}\text { Per unit- } \\
\text { area } \\
\left(\mathrm{m}^{3} / \mathrm{s} /\right. \\
\left.\mathrm{km}^{2}\right)\end{array}$ \\
\hline \multicolumn{6}{|c|}{1996} & \multicolumn{6}{|c|}{1997} \\
\hline 12 July & na & na & 90 & 510 & 24 & 5 Aug. & 4.00 & 7.00 & 5.5 & 0.23 & 0.011 \\
\hline & & & 1997 & & & 6 Aug. & 3.00 & 1.00 & 2.0 & 0.014 & 0.00066 \\
\hline 6 June & 9.75 & 0.50 & 5.1 & 0.0057 & 0.00027 & 7 Aug. & 5.00 & 1.50 & 3.2 & 0.017 & 0.00080 \\
\hline 6 June & 16.75 & 11.25 & 14.0 & 0.0057 & 0.00027 & 9 Aug. & 11.75 & 8.75 & 10.2 & 0.57 & 0.027 \\
\hline 7 June & 7.00 & 0.50 & 3.8 & 0.011 & 0.00052 & 11 Aug. & 0.00 & 7.50 & 3.8 & 0.059 & 0.0028 \\
\hline 7 June & 0.50 & 8.75 & 4.6 & 0.014 & 0.00066 & 12 Aug. & 0.00 & 9.75 & 4.9 & 0.079 & 0.0037 \\
\hline 8 June & 2.50 & 0.00 & 1.2 & 0.0057 & 0.00027 & 12 Aug. & 11.25 & 4.50 & 7.9 & 0.13 & 0.0061 \\
\hline 8 June & 1.00 & 1.00 & 1.0 & 0.0057 & 0.00027 & 13 Aug. & 0.50 & 0.00 & 0.2 & 0.0057 & 0.00027 \\
\hline 8 June & 2.00 & 0.50 & 1.2 & 0.0085 & 0.00040 & 17 Aug. & 1.00 & 2.50 & 1.8 & 0.051 & 0.0024 \\
\hline 8 June & 3.00 & 2.50 & 2.8 & 0.0057 & 0.00027 & 17 Aug. & 4.00 & 1.00 & 2.5 & 0.011 & 0.00052 \\
\hline 9 June & 0.50 & 0.00 & 0.2 & 0.0028 & 0.00013 & 17 Aug. & 1.50 & 3.00 & 2.2 & 0.042 & 0.0020 \\
\hline 9 June & 0.50 & 3.50 & 2.0 & 0.011 & 0.00052 & 17 Aug. & 1.00 & 2.50 & 1.8 & 0.034 & 0.0016 \\
\hline 9 June & 1.00 & 0.50 & 0.8 & 0.0085 & 0.00040 & 19 Aug. & 1.00 & 5.00 & 3.0 & 0.014 & 0.00066 \\
\hline 12 June & 2.50 & 1.50 & 2.0 & 0.011 & 0.00052 & 22 Aug. & 1.50 & 5.50 & 3.5 & 0.045 & 0.0021 \\
\hline 12 June & 0.50 & 0.50 & 0.5 & 0.0057 & 0.00027 & 24 Aug. & 10.75 & 1.00 & 5.9 & 0.037 & 0.0017 \\
\hline 13 June & 1.50 & 1.00 & 1.2 & 0.0 & 0.0 & 25 Aug. & 2.00 & 2.50 & 2.2 & 0.059 & 0.0028 \\
\hline 13 June & 0.00 & 7.50 & 3.8 & 0.023 & 0.0011 & 25 Aug. & 0.50 & 0.50 & 0.5 & 0.0057 & 0.00027 \\
\hline 14 June & 1.50 & 2.00 & 1.8 & 0.10 & 0.0047 & 25 Aug. & 2.00 & 1.00 & 1.5 & 0.037 & 0.0017 \\
\hline 15 June & 2.50 & 1.00 & 1.8 & 0.062 & 0.0029 & 26 Aug. & 0.00 & 2.00 & 1.0 & 0.031 & 0.0015 \\
\hline 16 June & 0.00 & 0.50 & 0.2 & 0.0057 & 0.00027 & 26 Aug. & 28.00 & 11.25 & 19.6 & 6.6 & 0.31 \\
\hline 17 June & 0.00 & 8.00 & 4.0 & 0.017 & 0.00080 & 28 Aug. & 2.00 & 1.00 & 1.5 & 0.034 & 0.0016 \\
\hline 18 June & 13.25 & 1.50 & 7.4 & 0.042 & 0.0020 & 31 Aug. & 15.75 & 88.00 & 51.9 & 140 & 6.6 \\
\hline 21 June & 6.00 & 6.00 & 6.0 & 1.4 & 0.066 & \multicolumn{6}{|c|}{ Stream gage was damaged. } \\
\hline 21 June & 3.00 & 0.00 & 1.5 & 0.034 & 0.0016 & & & & & & \\
\hline 21 June & 3.00 & 2.00 & 2.5 & 0.14 & 0.0066 & \multicolumn{6}{|c|}{1998} \\
\hline 21 June & 2.50 & 0.50 & 1.5 & 0.11 & 0.0052 & 8 June & 6.50 & 1.00 & 3.8 & 0.011 & 0.00052 \\
\hline 23 June & 1.00 & 1.00 & 1.0 & 0.074 & 0.0035 & 8 June & 4.00 & 2.00 & 3.0 & 0.014 & 0.00066 \\
\hline 24 June & 3.00 & 1.50 & 2.2 & 0.18 & 0.0085 & 14 June & 4.50 & 13.75 & 9.1 & 0.034 & 0.0016 \\
\hline 28 July & 14.25 & 10.25 & 12.2 & 1.1 & 0.052 & 20 June & 0.50 & 2.00 & 1.2 & 0.011 & 0.00052 \\
\hline 29 July & 25.00 & 13.25 & 19.1 & 5.0 & 0.24 & 21 June & 1.00 & 0.00 & 0.5 & 0.0028 & 0.00013 \\
\hline 30 July & 7.50 & 3.00 & 5.0 & 0.011 & 0.00052 & 21 June & 0.50 & 1.50 & 1.0 & 0.0028 & 0.00013 \\
\hline 31 July & 40.75 & 24.00 & 32.4 & 3.6 & 0.17 & 30 June & 1.00 & 0.50 & 0.8 & 0.0057 & 0.00027 \\
\hline 31 July & 7.50 & 3.50 & 5.5 & 0.040 & 0.0019 & 8 July & 17.25 & 7.50 & 12.4 & 0.020 & 0.00094 \\
\hline 1 Aug. & 0.50 & 0.50 & 0.5 & 0.0057 & 0.00027 & 9 July & 44.25 & 7.00 & 25.6 & 48 & 2.3 \\
\hline 2 Aug. & 4.50 & 0.50 & 2.5 & 0.014 & 0.00066 & \multicolumn{6}{|c|}{ Stream gage was damaged from 9-11 July. } \\
\hline 4 Aug. & 3.00 & 1.50 & 2.2 & 0.0085 & 0.00040 & 21 July & 12.25 & 5.50 & 8.9 & 0.023 & 0.0011 \\
\hline 4 Aug. & 2.00 & 1.50 & 1.8 & 0.0057 & 0.00027 & 22 July & 12.25 & 2.50 & 7.4 & 0.040 & 0.0019 \\
\hline 4 Aug. & 2.00 & 3.00 & 5.5 & 0.0028 & 0.00013 & 22 July & 3.50 & 3.00 & 3.2 & 0.034 & 0.0016 \\
\hline 5 Aug. & 5.50 & 0.50 & 3.0 & 0.0057 & 0.00027 & 28 July & 5.50 & 10.25 & 7.9 & 0.023 & 0.0011 \\
\hline 5 Aug. & 5.50 & 4.50 & 5.0 & 0.0057 & 0.00027 & 28 July & 2.50 & 1.00 & 1.8 & 0.0057 & 0.00027 \\
\hline
\end{tabular}


Table 3.3. (Continued) Rainfall intensity and peak discharges for the Spring Creek watershed, 1997-2000

\begin{tabular}{|c|c|c|c|c|c|c|c|c|c|c|c|}
\hline \multirow[b]{2}{*}{$\begin{array}{c}\text { Day } \\
\text { Month }\end{array}$} & \multicolumn{3}{|c|}{$\mathrm{I}_{30}(\mathrm{~mm} / \mathrm{h})$} & \multicolumn{2}{|c|}{ Peak discharge } & \multirow[b]{2}{*}{$\begin{array}{c}\text { Day } \\
\text { Month }\end{array}$} & \multicolumn{3}{|c|}{$I_{30}(\mathrm{~mm} / \mathrm{h})$} & \multicolumn{2}{|c|}{ Peak discharge } \\
\hline & $\begin{array}{c}\text { Long } \\
\text { Scraggy } \\
\text { Ranch }\end{array}$ & $\begin{array}{l}\text { Spring } \\
\text { Creek } \\
\text { above } \\
\text { mouth }\end{array}$ & Average & $\begin{array}{l}\text { Above } \\
\text { back- } \\
\text { ground } \\
\left(\mathrm{m}^{3} / \mathrm{s}\right)\end{array}$ & $\begin{array}{c}\text { Per unit- } \\
\text { area } \\
\left(\mathrm{m}^{3} / \mathrm{s} /\right. \\
\left.\mathrm{km}^{2}\right)\end{array}$ & & $\begin{array}{c}\text { Long } \\
\text { Scraggy } \\
\text { Ranch }\end{array}$ & $\begin{array}{l}\text { Spring } \\
\text { Creek } \\
\text { above } \\
\text { mouth }\end{array}$ & Average & $\begin{array}{l}\text { Above } \\
\text { back- } \\
\text { ground } \\
\left(\mathrm{m}^{3} / \mathrm{s}\right)\end{array}$ & $\begin{array}{c}\text { Per unit- } \\
\text { area } \\
\left(\mathrm{m}^{3} / \mathrm{s} /\right. \\
\left.\mathrm{km}^{2}\right)\end{array}$ \\
\hline \multicolumn{6}{|c|}{1998} & \multicolumn{6}{|c|}{1999} \\
\hline 28 July & 13.25 & 0.00 & 6.6 & 0.037 & 0.0017 & 4 Aug. & 16.25 & 14.25 & 15.2 & 0.91 & 0.043 \\
\hline 31 July & 61.00 & 28.50 & 44.8 & 82 & 3.9 & 7 Aug. & 0.00 & 13.25 & 6.6 & 0.065 & 0.0031 \\
\hline \multicolumn{6}{|c|}{ Stream gage was not functioning from 1 August to 17 August } & 8 Aug. & 14.25 & 1.50 & 7.9 & 0.13 & 0.0061 \\
\hline 17 Aug. & 2.00 & 1.50 & 1.8 & 0.017 & 0.00080 & 15 Aug. & 10.25 & 2.50 & 6.4 & 0.023 & 0.0011 \\
\hline 18 Aug. & 2.00 & 0.50 & 1.2 & 0.0057 & 0.00027 & 17 Aug. & 12.75 & 11.25 & 12.0 & 0.15 & 0.0071 \\
\hline 24 Aug. & 10.75 & 4.00 & 7.4 & 0.017 & 0.00080 & 21 Aug. & 1.00 & 0.50 & 0.8 & 0.025 & 0.0012 \\
\hline 25 Aug. & 2.00 & 2.00 & 2.0 & 0.020 & 0.00094 & 25 Aug. & 16.25 & 1.50 & 8.9 & 0.065 & 0.0031 \\
\hline 31 Aug. & 15.75 & 5.00 & 10.4 & 0.0085 & 0.00040 & 25 Aug. & 3.50 & 2.50 & 3.0 & 0.045 & 0.0021 \\
\hline & & & 1999 & & & 27 Aug. & 4.50 & 0.00 & 2.2 & 0.017 & 0.00080 \\
\hline 9 June & 5.50 & 2.50 & 4.0 & 0.028 & 0.0013 & 27 Aug. & 4.00 & 4.00 & 4.0 & 0.023 & 0.0011 \\
\hline 9 June & 4.50 & 3.50 & 4.0 & 0.014 & 0.00066 & 29 Aug. & 1.00 & 3.00 & 2.0 & 0.028 & 0.0013 \\
\hline 10 June & 4.00 & 4.00 & 4.0 & 0.014 & 0.00066 & 31 Aug. & 1.50 & 1.00 & 2.2 & 0.0085 & 0.00040 \\
\hline 10 June & 12.25 & 6.00 & 9.1 & 0.042 & 0.0020 & \multicolumn{6}{|c|}{2000} \\
\hline 11 June & 4.50 & 7.75 & 6.1 & 0.025 & 0.0012 & 12 July & 4.50 & 10.75 & 7.6 & 0.037 & 0.0017 \\
\hline 11 June & 0.50 & 1.00 & 0.8 & 0.0057 & 0.00027 & 16 July & 31.50 & 67.00 & 49.2 & 2.4 & 0.11 \\
\hline 3 July & 1.50 & 1.50 & 1.5 & 0.045 & 0.0021 & 17 July & 34.00 & 4.50 & 19.2 & 0.065 & 0.0031 \\
\hline 8 July & 2.50 & 18.75 & 10.6 & 0.014 & 0.00066 & 4 Aug. & 1.00 & 5.50 & 6.2 & 0.0085 & 0.00040 \\
\hline 11 July & 29.00 & 1.00 & 15.0 & 0.062 & 0.0029 & 13 Aug. & 7.50 & 7.50 & 7.5 & 0.023 & 0.0011 \\
\hline 14 July & 3.00 & 0.00 & 1.5 & 0.011 & 0.00052 & 17 Aug. & 8.75 & 5.50 & 7.0 & 0.017 & 0.00080 \\
\hline 15 July & 2.50 & 1.50 & 2.0 & 0.011 & 0.00052 & 20 Aug. & 1.00 & 20.25 & 10.6 & 0.031 & 0.0015 \\
\hline 17 July & 6.50 & 35.00 & 20.8 & 0.040 & 0.0019 & 26 Aug. & 4.50 & 11.25 & 7.9 & 0.017 & 0.00080 \\
\hline 19 July & 0.00 & 2.00 & 1.0 & 0.0057 & 0.00027 & 28 Aug. & 3.00 & 6.00 & 4.5 & 0.011 & 0.00052 \\
\hline 22 July & 1.00 & 1.00 & 1.0 & 0.011 & 0.00052 & 31 Aug. & 8.25 & 7.50 & 7.9 & 0.011 & 0.00052 \\
\hline 28 July & 46.75 & 4.00 & 25.4 & 0.14 & 0.0066 & 5 Sept. & 5.50 & 7.50 & 6.5 & 0.020 & 0.00094 \\
\hline 29 July & 35.50 & 1.0 & 18.2 & 6.4 & 0.30 & 21 Sept & 8.25 & 3.00 & 5.6 & 0.011 & 0.00052 \\
\hline 30 July & 15.75 & 2.50 & 9.1 & 0.11 & 0.0052 & 24 Sept. & 3.50 & 6.50 & 5.0 & 0.0085 & 0.00040 \\
\hline 31 July & 9.25 & 10.25 & 9.8 & 0.12 & 0.0057 & & & & & & \\
\hline 31 July & 11.25 & 5.00 & 8.1 & 0.062 & 0.0029 & & & & & & \\
\hline 31 July & 11.75 & 5.00 & 8.4 & 0.11 & 0.0052 & & & & & & \\
\hline
\end{tabular}


Table 3.4. Post-fire flood characteristics in the watersheds burned by the Buffalo Creek Fire, 1996-2000.

[Includes floods in either watershed when the peak discharge was greater than 10 times the baseflow for June, July, and August 1997 and 1998 (table 1.1) or when the maximum 30-minute intensity, $\mathrm{I}_{30}$, was greater than $10 \mathrm{~mm} / \mathrm{h}$; unit-area peak discharge, peak discharge/burned area; Ave., average; , estimated; na, not available; ni, no increase above baseflow; $\mathrm{mm} / \mathrm{h}$, millimeters per hour; $\mathrm{m}^{3} / \mathrm{s}$, cubic meter per second; $\mathrm{m}^{3} / \mathrm{s} / \mathrm{km}^{2}$, cubic meter per second per square kilometer]

\begin{tabular}{|c|c|c|c|c|c|c|c|c|c|c|}
\hline \multirow{3}{*}{ Date } & \multicolumn{5}{|c|}{ Buffalo Creek Watershed } & \multicolumn{5}{|c|}{ Spring Creek Watershed } \\
\hline & \multicolumn{3}{|c|}{$\mathbf{I}_{30}(\mathrm{~mm} / \mathrm{h})$} & \multirow{2}{*}{$\begin{array}{c}\text { Peak } \\
\text { discharge } \\
\left(\mathrm{m}^{3} / \mathbf{s}\right)\end{array}$} & \multirow{2}{*}{$\begin{array}{c}\text { Unit-area } \\
\text { peak } \\
\text { discharge } \\
\left(\mathrm{m}^{3} / \mathbf{s} / \mathbf{k m}^{2}\right)\end{array}$} & \multicolumn{3}{|c|}{$I_{30}(\mathrm{~mm} / \mathrm{h})$} & \multirow{2}{*}{$\begin{array}{c}\text { Peak } \\
\text { discharge } \\
\left(\mathrm{m}^{3} / \mathbf{s}\right)\end{array}$} & \multirow{2}{*}{$\begin{array}{c}\text { Unit-area } \\
\text { peak } \\
\text { discharge } \\
\left(\mathrm{m}^{3} / \mathrm{s} / \mathrm{km}^{2}\right) \\
\end{array}$} \\
\hline & $\begin{array}{c}\text { Morri- } \\
\text { son }\end{array}$ & $\begin{array}{l}\text { Buffalo } \\
\text { Creek }\end{array}$ & Ave. & & & $\begin{array}{c}\text { Long } \\
\text { Scraggy } \\
\end{array}$ & $\begin{array}{l}\text { Spring } \\
\text { Creek }\end{array}$ & Ave. & & \\
\hline & & & & & 1996 & & & & & \\
\hline 12 June & na & na & na & na & na & na & na & na & 20 & 0.94 \\
\hline 12 July & na & na & $80 .^{\mathrm{a}}$ & $4500^{\mathrm{c}}$ & 18 & na & na & $-90^{a b b}$ & $510 .^{c}$ & 24 \\
\hline 23 Aug. & na & na & -30 & $40 .^{b}$ & 1.6 & na & na & na & 30 & 1.4 \\
\hline 14 Sept. & na & na & $10-18^{b}$ & 5 & $\begin{array}{l}0.2 \\
1997\end{array}$ & na & na & na & 7 & 0.33 \\
\hline 6 June & 17.75 & 20.75 & 19.2 & 13 & 0.51 & 16.75 & 11.25 & 14.0 & 0.0057 & 0.00027 \\
\hline 28 July & 10.75 & 19.75 & 15.2 & 13 & 0.51 & 14.75 & 10.25 & 12.2 & 1.1 & 0.052 \\
\hline 29 July & 15.25 & 15.25 & 15.2 & $30.5^{\mathrm{d}}$ & 1.2 & 25.00 & 13.75 & 19.1 & $5.0^{d}$ & 0.24 \\
\hline 31 July & 22.25 & 37.00 & 29.6 & 8.3 & 0.32 & 40.75 & 24.00 & 32.4 & 3.6 & 0.17 \\
\hline 2 Aug. & 5.00 & 11.25 & 8.1 & 8.2 & 0.32 & 4.50 & 0.50 & 2.5 & 0.014 & 0.00066 \\
\hline 9 Aug. & 36.00 & 16.25 & 12.2 & 9.9 & 0.39 & 11.75 & 8.75 & 10.2 & 0.57 & 0.027 \\
\hline 26 Aug. & 14.25 & 8.75 & 11.5 & 0.7 & 0.027 & 28.00 & 11.25 & 19.6 & 6.6 & 0.31 \\
\hline 31 Aug. & 1.00 & 14.75 & 7.9 & 5.3 & $\begin{array}{l}0.21 \\
1998\end{array}$ & 15.75 & 88.00 & 51.9 & $140 .^{d}$ & 6.6 \\
\hline 8 July & 4.50 & 5.50 & 5.0 & ni & $\mathrm{ni}$ & 17.25 & 7.50 & 12.4 & 0.020 & 0.00094 \\
\hline 9 July & 1.00 & 5.50 & 3.2 & $\mathrm{ni}$ & $\mathrm{ni}$ & 44.25 & 7.00 & 25.6 & $48 .^{d}$ & 2.3 \\
\hline 31 July & 10.25 & 50.75 & 30.5 & \multicolumn{2}{|c|}{ gage damaged } & 61.00 & 28.50 & 44.8 & $82 .^{d}$ & 3.9 \\
\hline 31 Aug. & 7.00 & 3.00 & 5.0 & 0.11 & $\begin{array}{r}0.0043 \\
1999\end{array}$ & 15.75 & 5.00 & 10.4 & 0.0085 & 0.00040 \\
\hline 8 July & 2.50 & 2.50 & 2.5 & ni & $\mathrm{ni}$ & 2.50 & 18.75 & 10.6 & 0.014 & 0.00066 \\
\hline 11 July & 2.00 & 17.25 & 9.6 & 0.20 & 0.0078 & 29.00 & 1.00 & 15.0 & 0.062 & 0.0029 \\
\hline 17 July & 11.25 & 16.25 & 13.8 & $\mathrm{ni}$ & ni & 6.50 & 35.00 & 20.8 & 0.040 & 0.0019 \\
\hline 28 July & 8.75 & 6.00 & 7.4 & $\mathrm{ni}$ & $\mathrm{ni}$ & 46.75 & 4.00 & 25.4 & 0.14 & 0.0066 \\
\hline 29 July & 3.50 & 27.50 & 15.5 & 5.1 & 0.20 & 35.50 & 1.00 & 18.2 & 6.4 & 0.30 \\
\hline 4 Aug. & 7.00 & 6.50 & 6.8 & 0.080 & 0.0031 & 16.25 & 14.25 & 15.2 & 0.91 & 0.043 \\
\hline 17 Aug. & 0.00 & 0.50 & 0.5 & $\mathrm{ni}$ & $\begin{array}{l}\text { ni } \\
2000\end{array}$ & 12.75 & 11.25 & 12.0 & 0.15 & 0.0071 \\
\hline 16 July & 7.50 & 32.50 & 20.0 & ni & $\mathrm{ni}$ & 31.50 & 67.00 & 49.2 & 2.4 & 0.11 \\
\hline 17 July & 48.75 & 24.50 & 36.6 & ni & ni & 34.00 & 4.50 & 19.2 & 0.065 & 0.0031 \\
\hline 20 Aug. & 1.50 & 1.00 & 2.2 & 0.028 & 0.001 & 1.00 & 20.25 & 10.6 & 0.031 & 0.0015 \\
\hline
\end{tabular}

${ }^{a}$ This is an average of the maximum one-hour intensities of $110 \mathrm{~mm} / \mathrm{h}$ at Long Scraggy Ranch and $75 \mathrm{~mm} / \mathrm{h}$ near the Spring Creek gage, Henz, 1998; Jarrett, 2001.

bJarrett, R. D., written commun., 1996.

'Yates and others, 2000.

${ }^{\mathrm{d}}$ Indirect discharge measurement. 
Table 3.5. Geometric characteristics for the channel cross section at the Spring Creek gage

[m, meter; $\mathrm{m}^{2}$, square meter]

\begin{tabular}{|c|c|c|c|c|c|c|c|}
\hline $\begin{array}{c}\text { Depth } \\
\text { (m) }\end{array}$ & $\begin{array}{l}\text { Area } \\
\left(m^{2}\right)\end{array}$ & $\begin{array}{c}\text { Width } \\
\text { (m) }\end{array}$ & $\begin{array}{l}\text { Hydraulic } \\
\text { radius } \\
\text { (m) }\end{array}$ & $\begin{array}{c}\text { Depth } \\
\text { (m) }\end{array}$ & $\begin{array}{l}\text { Area } \\
\left(\mathrm{m}^{2}\right)\end{array}$ & $\begin{array}{l}\text { Width } \\
\text { (m) }\end{array}$ & $\begin{array}{l}\text { Hydraulic } \\
\text { radius } \\
\text { (m) }\end{array}$ \\
\hline 0.00 & 0.00 & 0.00 & 0.0 & 1.16 & 8.78 & 9.91 & 0.83 \\
\hline 0.030 & 0.037 & 2.74 & 0.014 & 1.22 & 9.38 & 10.03 & 0.87 \\
\hline 0.061 & 0.14 & 3.66 & 0.038 & 1.28 & 10.00 & 10.15 & 0.91 \\
\hline 0.091 & 0.26 & 3.90 & 0.066 & 1.34 & 10.62 & 10.27 & 0.95 \\
\hline 0.12 & 0.38 & 4.05 & 0.093 & 1.40 & 11.25 & 10.39 & 1.00 \\
\hline 0.15 & 0.50 & 4.30 & 0.12 & 1.46 & 11.89 & 10.52 & 1.04 \\
\hline 0.18 & 0.64 & 4.63 & 0.14 & 1.52 & 12.53 & 10.58 & 1.08 \\
\hline 0.21 & 0.79 & 5.00 & 0.16 & 1.58 & 13.18 & 10.67 & 1.12 \\
\hline 0.24 & 0.95 & 5.36 & 0.18 & 1.65 & 13.83 & 10.73 & 1.16 \\
\hline 0.27 & 1.11 & 5.68 & 0.19 & 1.71 & 14.49 & 10.79 & 1.20 \\
\hline 0.30 & 1.29 & 5.94 & 0.21 & 1.77 & 15.15 & 10.85 & 1.25 \\
\hline 0.34 & 1.48 & 6.19 & 0.24 & 1.82 & 15.81 & 10.94 & 1.28 \\
\hline 0.37 & 1.67 & 7.28 & 0.23 & 1.89 & 16.48 & 11.00 & 1.33 \\
\hline 0.40 & 1.90 & 7.50 & 0.25 & 1.95 & 17.16 & 11.06 & 1.36 \\
\hline 0.43 & 2.13 & 7.71 & 0.27 & 2.01 & 17.83 & 11.13 & 1.40 \\
\hline 0.46 & 2.37 & 7.92 & 0.29 & 2.07 & 18.52 & 11.19 & 1.44 \\
\hline 0.49 & 2.61 & 8.14 & 0.31 & 2.13 & 19.19 & 11.28 & 1.47 \\
\hline 0.52 & 2.86 & 8.32 & 0.34 & 2.19 & 19.89 & 11.34 & 1.51 \\
\hline 0.55 & 3.12 & 8.53 & 0.36 & 2.26 & 20.58 & 11.40 & 1.55 \\
\hline 0.58 & 3.38 & 8.72 & 0.38 & 2.32 & 21.27 & 11.46 & 1.58 \\
\hline 0.61 & 3.65 & 8.78 & 0.41 & 2.38 & 21.98 & 11.56 & 1.62 \\
\hline 0.64 & 3.92 & 8.84 & 0.43 & 2.44 & 22.69 & 11.61 & 1.65 \\
\hline 0.67 & 4.19 & 8.90 & 0.46 & 2.50 & 23.39 & 11.67 & 1.69 \\
\hline 0.70 & 4.46 & 8.96 & 0.48 & 2.56 & 24.11 & 11.73 & 1.72 \\
\hline 0.73 & 4.74 & 9.02 & 0.51 & 2.62 & 24.82 & 11.80 & 1.76 \\
\hline 0.76 & 5.02 & 9.08 & 0.53 & 2.68 & 25.55 & 11.89 & 1.79 \\
\hline 0.79 & 5.30 & 9.17 & 0.56 & 2.74 & 26.27 & 11.95 & 1.82 \\
\hline 0.82 & 5.57 & 9.24 & 0.58 & 2.80 & 27.00 & 12.01 & 1.86 \\
\hline 0.85 & 5.85 & 9.30 & 0.60 & & & & \\
\hline 0.88 & 6.14 & 9.36 & 0.63 & & & & \\
\hline 0.91 & 6.42 & 9.42 & 0.65 & & & & \\
\hline 0.94 & 6.71 & 9.48 & 0.67 & & & & \\
\hline 0.98 & 7.00 & 9.54 & 0.70 & & & & \\
\hline 1.01 & 7.29 & 9.60 & 0.72 & & & & \\
\hline 1.04 & 7.58 & 9.66 & 0.74 & & & & \\
\hline 1.10 & 8.18 & 9.78 & 0.79 & & & & \\
\hline
\end{tabular}




\section{Section 4--HILLSLOPES}

Hillslopes are subdivided into interrill and rill areas. The areas were easy to distinguish after the intense rainstorms in 1996. Light yellowish-brown in appearance because they had eroded down to subsurface soils, the rill areas contrasted with the interrill areas, which were black from the color of the surface coating on the top of the gravel lag left behind as the fine material was eroded by the runoff.

\section{$\underline{\text { Methods }}$}

\section{Interrill}

\section{Hillslope Traps}

Hillslope sediment traps were deployed in interrill areas of severely burned and unburned hillslopes of the Spring Creek watershed. Traps were installed in the burned area on north-facing and south-facing hillslopes in 1997, one year after the wildfire, and in an unburned area on northfacing and south-facing hillslopes in 1998. Four replicate traps were installed on each hillslope (south-facing, severely burned; north-facing, severely burned; south-facing, unburned; and northfacing, unburned). An interrill sediment trap consisted of a trough constructed of PVC pipe with a $1.0-\mathrm{m} \times 0.05-\mathrm{m}$ collection slot. A thin metal apron was interfaced to the hillslope and connected to the slot to allow sediment to enter the trap (fig. 4.1) (Gerlach, 1967; Fitzhugh, 1992). Traps were installed perpendicular to the slope. A bucket collected sediment and water from the trough and additional buckets (connected in series) collected the water overflow from the trough. Metal edging enclosed the area of hillslope that contributed sediment to the trough. In 1997, these bounded plots were of variable size averaging $10 \mathrm{~m}^{2}$. Starting in 1998, the enclosures were reconfigured and standardized to $5 \mathrm{~m}^{2}$ ( $1 \mathrm{~m}$ wide $\mathrm{x} 5 \mathrm{~m}$ long). The collection slot was not covered, and runoff volumes reported in tables 4.1-4.4 include both runoff and direct rainfall through the slot.

Sediment and water from the four replicate traps were collected either after major storm events or as frequently as possible during the summer at all sites (tables $4.1-4.5$ ). Sediment from traps on the south-facing, severely-burned hillslope was also collected during the early spring and late fall to correspond to when data were collected from rill traps on the same hillslope. On the other hillslopes, sediment was allowed to accumulate throughout the winter until the first collection of the following summer. In addition to collecting eroded sediment, $5-\mathrm{cm}$ diameter $\times 10-\mathrm{cm}$ deep soil cores from the burned and unburned, north- and south-facing hillslopes were collected to characterize the particle-size distribution of the source of sediment collected in the hillslope traps (table 4.6 and fig. 4.2).

Even using bounded plots, it is impossible to determine what percentage of the bounded area actually contributed sediment to the traps. The intensity and duration of each rainstorm is different, and the subsequent runoff transports sediment from different distances upslope into the trap. Even within a single rainstorm, runoff will transport different particle sizes for different distances downslope into the traps. Therefore, data are given as sediment flux rates, which are calculated as the mass of sediment transported across a unit contour ( 1 meter) per unit time (1 day). Because sediment in the traps was not collected for the same time intervals each year, the sediment flux was multiplied by the number of days in the appropriate season (122 days for the summer season, 243 days for the winter season) to estimate comparable seasonal fluxes (table 4.5). 
Sediment fluxes are reported for both the summer months (June-September) and for the winter months (October-May), based on the mass of sediment collected from the hillslope traps.

Because sediment samples were not collected after each storm, the data from each collection date represent the sediment moved by a variety of hillslope-transport processes.

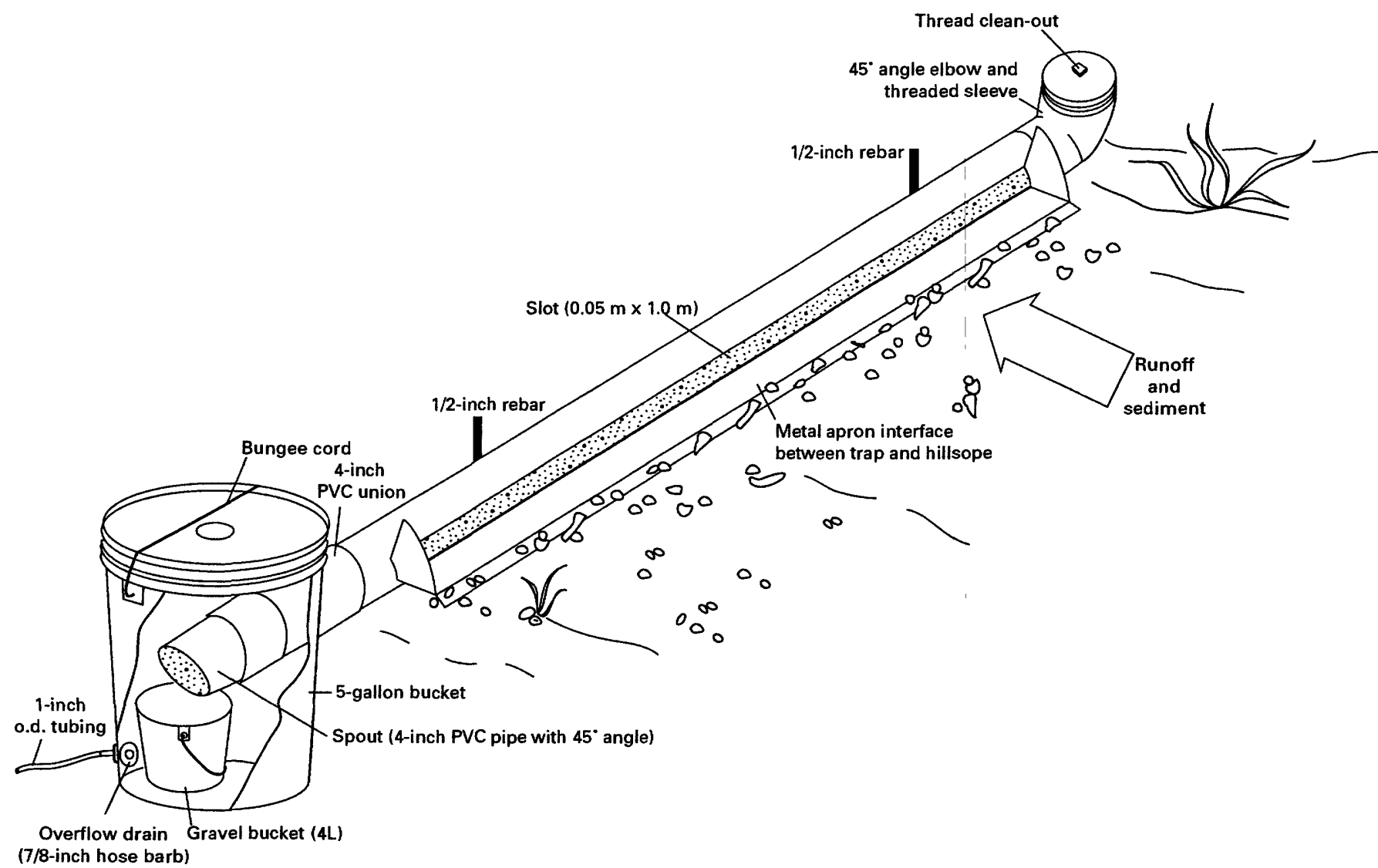

Figure 4.1. Hillslope sediment trap. During high runoffs, the gravel bucket collects mostly gravel and sand and some water, while the 5-gallon bucket, and similar 5-gallon overflow buckets connected to the overflow drain in series, collect the fine silts and clays and the remaining water. During low runoff, the gravel bucket collects gravel, sand silt, clay and water. The metal apron was interfaced to the hillslope by cutting a shallow slot (about 0.01 to $0.02 \mathrm{~cm}$ ) for the thin metal and then driving a heavier gage sheet metal (about 1/4-inch thick, $1.0 \mathrm{~m}$ long and $0.06 \mathrm{~m}$ wide) into the hillslope on top of the thinner sheet metal forming the apron.

\section{Particle-size Distribution}

Most of the sediment collected in the hillslope sediment traps was brought back and processed in the laboratory. In the field, the total volume of water in the buckets was measured and recorded. If the water contained suspended sediment, the water was mixed in a churn splitter (Meade and Stevens, 1990) and a 1-L water subsample taken to the laboratory. The filtered sediment sample was dried at $105^{\circ} \mathrm{C}$ and weighed to determine the mass. To determine the particlesize distribution, the dry sediment was sieved by whole phi $(\Phi)$ intervals $\left(\Phi=-\log _{2}\right.$ of the particle 
size diameter in $\mathrm{mm}$; Krumbein, 1934). In addition, when sufficient dry sediment existed, a 1gram subsample of the $<0.063 \mathrm{~mm}$ particle size class was settled following the methods described by Guy $(1969)$ to determine the silt $(0.004-0.063 \mathrm{~mm})$ and the clay $(<0.004 \mathrm{~mm})$ particle-size fractions. The mass of silt and clay in the water subsample was measured and added to the dry sediment sample to obtain the total particle size distribution. The median particle diameter $\left(\mathrm{D}_{50}\right)$ was calculated by linear interpolation. Particle-size distribution curves (fig. 4.2) were fit to the data using a cubic-spline program (R. Stallard, written commun., 1997), and 95 percent confidence limits were computed using the Student-t distribution.

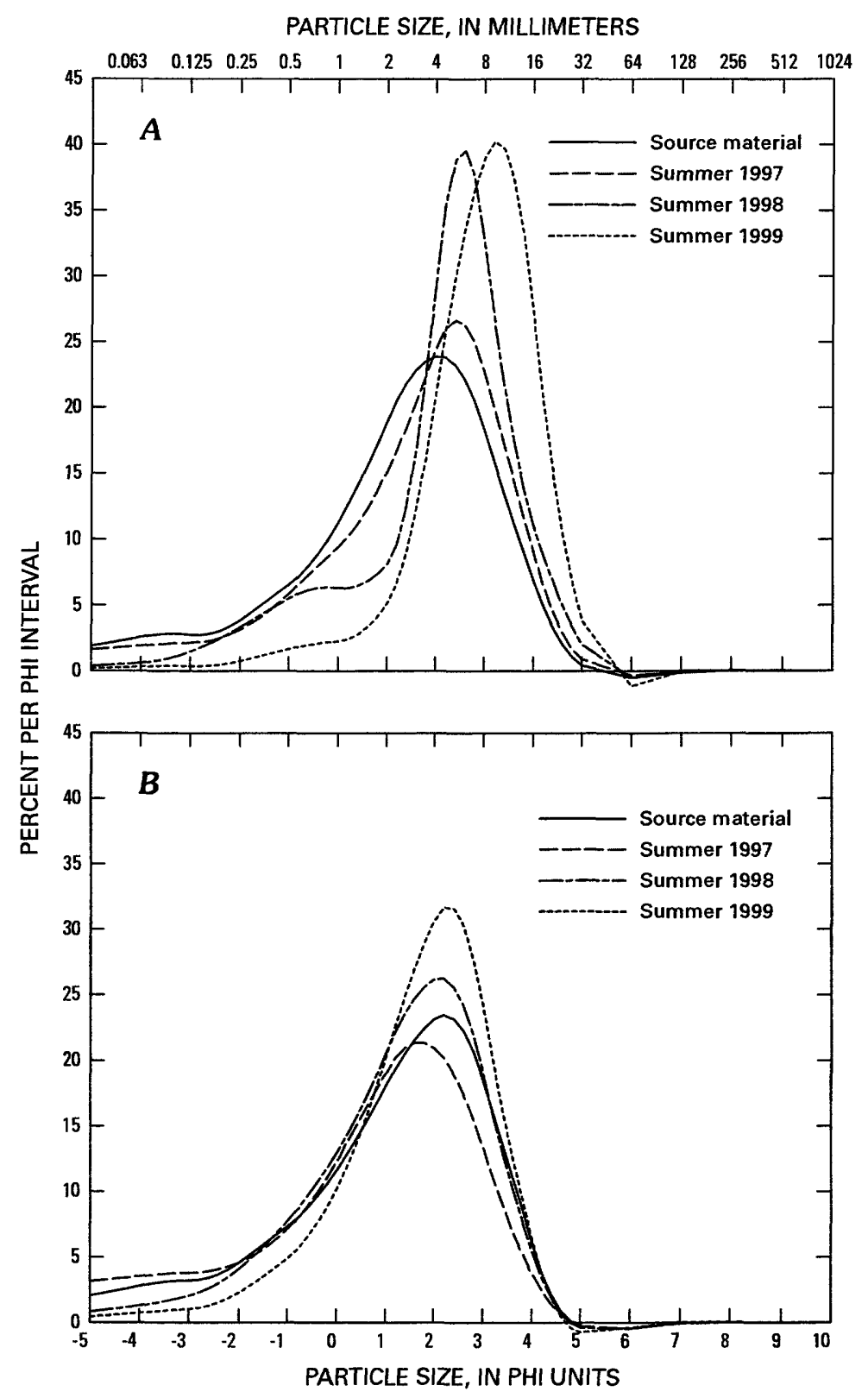

Figure 4.2. Particle-size distributions of eroded sediment (summer only) and source material

A. South-facing burned hillslope. B. North-facing burned hillslope 


\section{Rills}

Rills were studied on hillslopes in several subwatersheds, and on a hillslope draining directly into Spring Creek starting in 1998. Investigations focused on (1) the characteristic channel geometry and changes down the hillslope, (2) the evolution of this geometry with time, (3) the volume of sediment eroded from the rills during the first post-fire rainstorms, and (4) the sediment transport rates in rills during the year. On some hillslopes, the rills were numerous, and transects were established across these rill fields to measure rill width and depths using a carpenter's level and metric ruler. For example, figure 4.3 shows a typical rill field where transects were run approximately parallel to the elevation contours and spaced $10 \mathrm{~m}$ apart.

\section{Rill Surveys}

Segments of rills labelled A, B and C in figure 4.3A were surveyed in more detail and at various time intervals over two years (1998-2000) to monitor the evolution of the rills (Appendix 1). A set of five cross sections, spaced one meter apart in the downslope direction, were established on Rills A, B, and C with reference pins (4-foot long, 1/2-inch rebar, Appendix 2) at each end. Two ladders were placed on the hillside on either side of the reference pins and prevented from sliding downhill by two shorter pieces of rebar driven into the ground just downhill from a rung (fig. 4.4A). A ladder jack was put on each ladder, and a plywood platform was placed across the ladder jacks to provide a place to sit while measuring the rill cross section and to avoid disturbing the rill. Cross-sectional elevations were measured to an accuracy of $0.0005 \mathrm{~m}$ using an erosion bridge (fig. 4.4B) with holes spaced about $0.01 \mathrm{~m}$ apart. After the cross section was measured, the ladder jacks and plywood platform were repositioned on the two ladders below the next downhill cross section. Files of the cross-section measurements for the rills are on the accompanying CD where the format of the files is listed in Appendix 1.

Rill erosion during two major floods in 1996 and 1997 was estimated from aerial photographs and field measurements made in 1999. The number and spatial distribution of rills on hillslopes were counted and mapped on aerial photographs (1:3000 scale) of two subwatersheds in the Spring Creek watershed. One subwatershed, W960 (960 m upstream from the mouth of Spring Creek), is a south-facing, third-order watershed with an area of 7.0 ha and an estimated channel density of $21 \mathrm{~km} / \mathrm{km}^{2}$ after the fire. W1165 (1165 m upstream from the mouth of Spring Creek) is a north-facing, fourth-order watershed with an area of 3.7 ha and an estimated channel density of $48 \mathrm{~km} / \mathrm{km}^{2}$. Additional field measurements of rill length and cross-sectional area were made in W960, W1165, and in other subwatersheds in 1999. The eroded volumes for these two subwatersheds were calculated as the product of the mean cross-sectional area, mean rill length, and the number of rills that actually delivered sediment to the channels as shown by aerial photographs and field observations. 


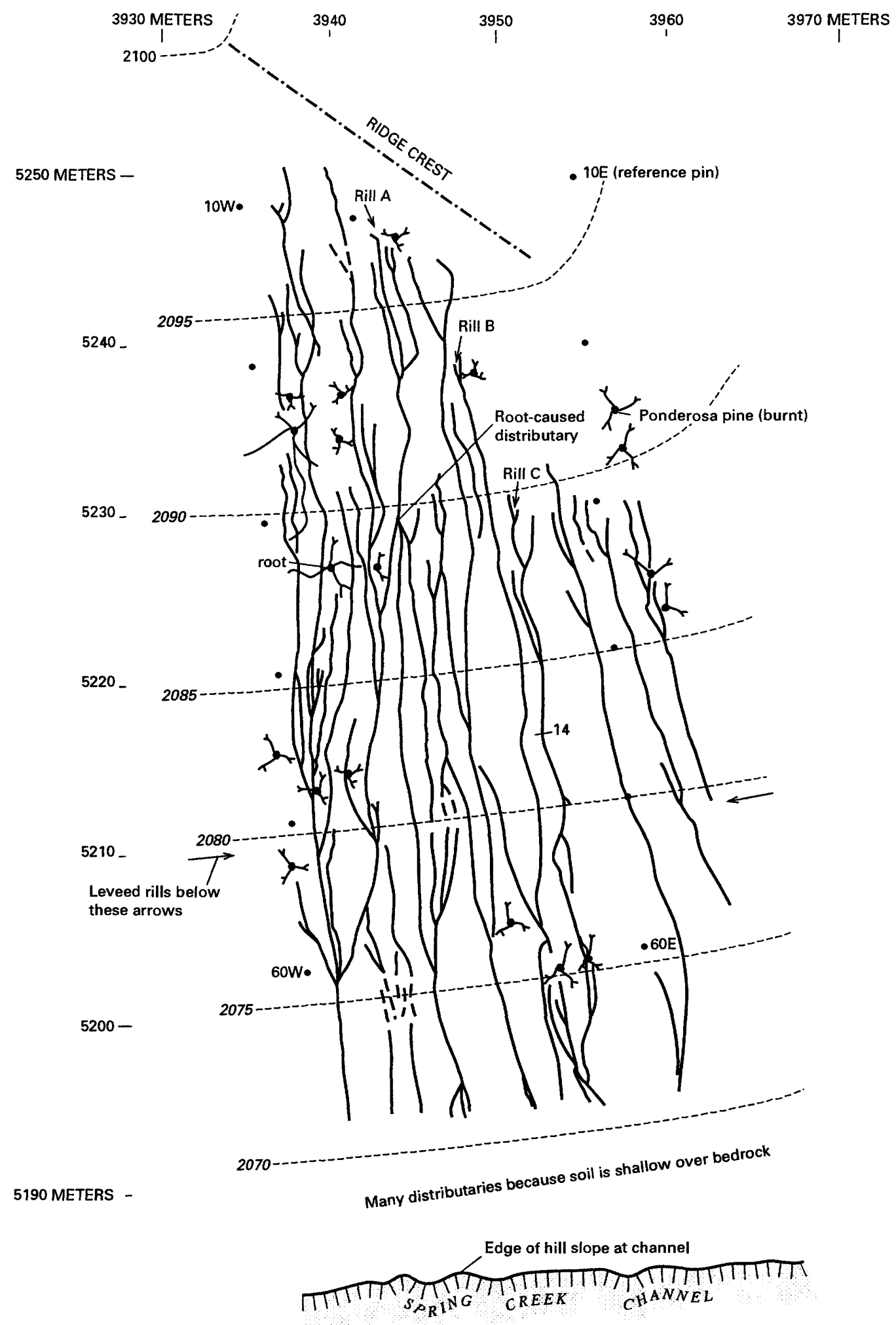

Figure 4.3. A. Map of rill field on south-facing hillslope where both interrill and rill traps have been deployed. The coordinates shown across the top and along the left edge are in the arbitrary coordinate system. Black dots are the locations of reference pins (1/2-inch rebar) for transects spaced $10 \mathrm{~m}$ apart. Dashed lines are contours. Cross section 1400 on Rill C is indicated as 14 on the map. 


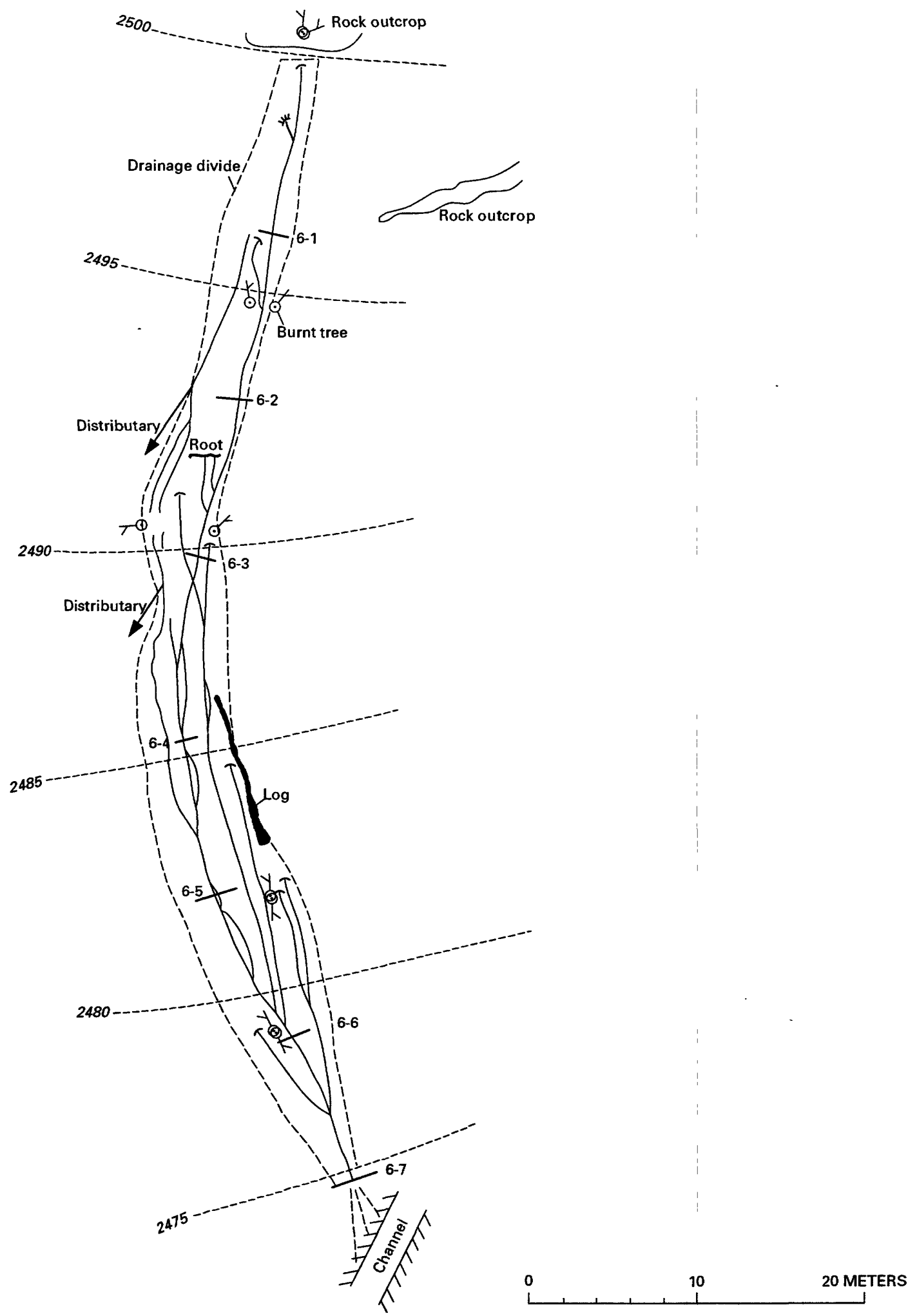

Figure 4.3 B. Map of Rill 6 (cross sections 6-1 to 6-7) on part of a northwest-facing hillslope. No arbitrary coordinates were measured in this area. 

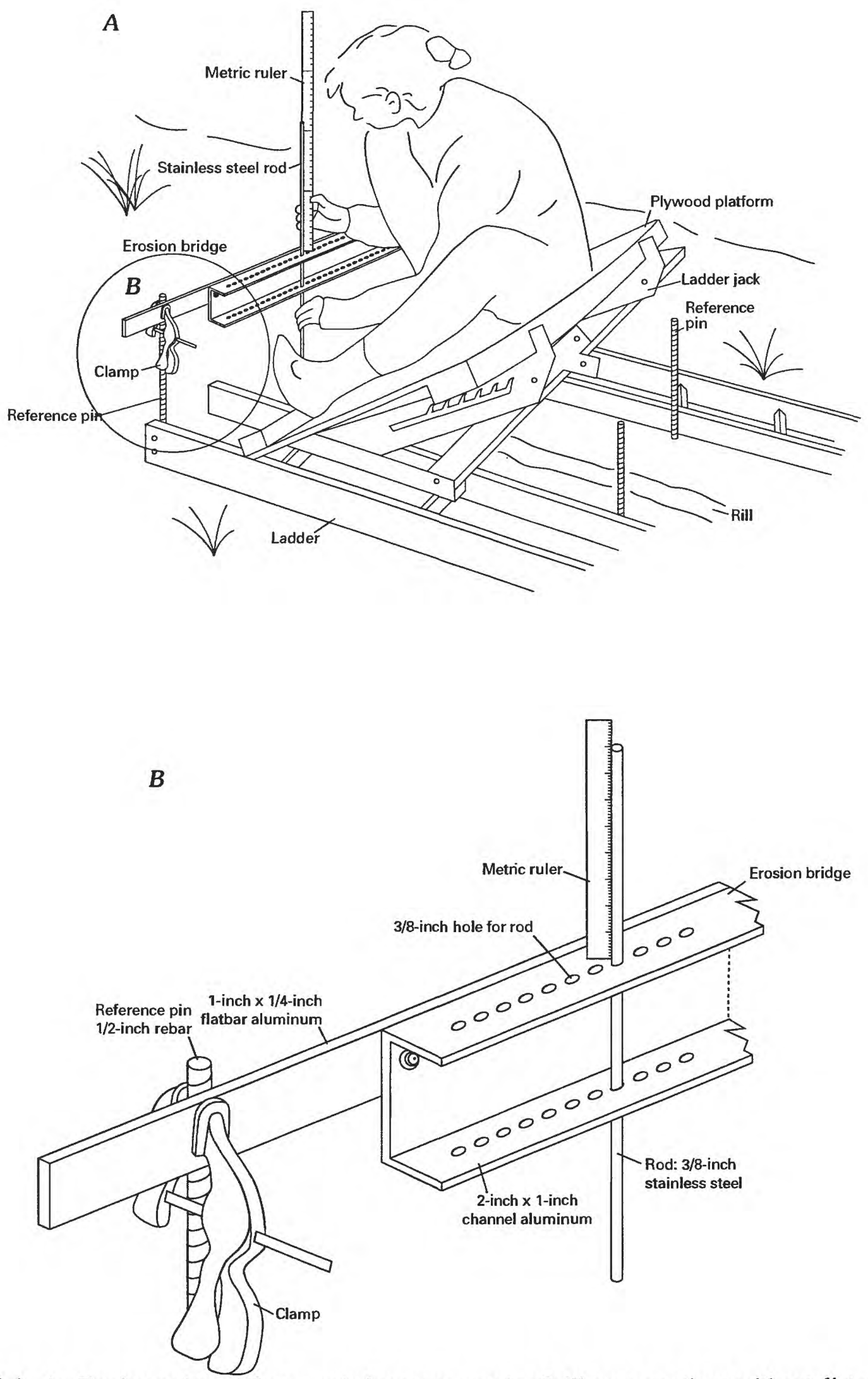

Figure 4.4. A. Equipment used for repeated measurements of rill cross sections without disturbing the rills. Normally, the reference pins were between the two ladders, with one exception shown here for the beginning of rill A. The area within the circle is enlarged in 4.4B.

B. One end of the erosion bridge, which has holes spaced about $0.010 \mathrm{~m}$ apart. 


\section{Rill Traps}

Three rill traps (fig. 4.5) were deployed in 1998 to collect water and sediment. Each rill trap was located on a different rill and at a different distance from the beginning of the rill. Rill A represented the beginning segment of a rill with cross sections at $0,1,2,3$, and $4 \mathrm{~m}$ from the beginning of the rill and a rill trap installed just below section 4 . Because this rill trap would compromise any measurements of processes in the rill downhill, a different, but similarly sized, rill (Rill B) was selected to represent processes at 4, 5, 6, 7, and $8 \mathrm{~m}$ downstream from the beginning of the rill. A second rill trap was installed just below cross section 8 . Similarly, Rill C represented processes at $10,11,12,13$, and $14 \mathrm{~m}$ downstream from the beginning of the rill with a trap just below section 14. Water volume collected in these traps was measured and the particlesize distributions were determined by sieving on a RoTap for 15-20 minutes, weighing, and reporting by whole phi sizes (Guy, 1969). Because the area contributing to a rill was not known, sediment transport in the rills is expressed as a flux $(\mathrm{kg} / \mathrm{m})$ of sediment mass across a unit contour width (table 4.7).

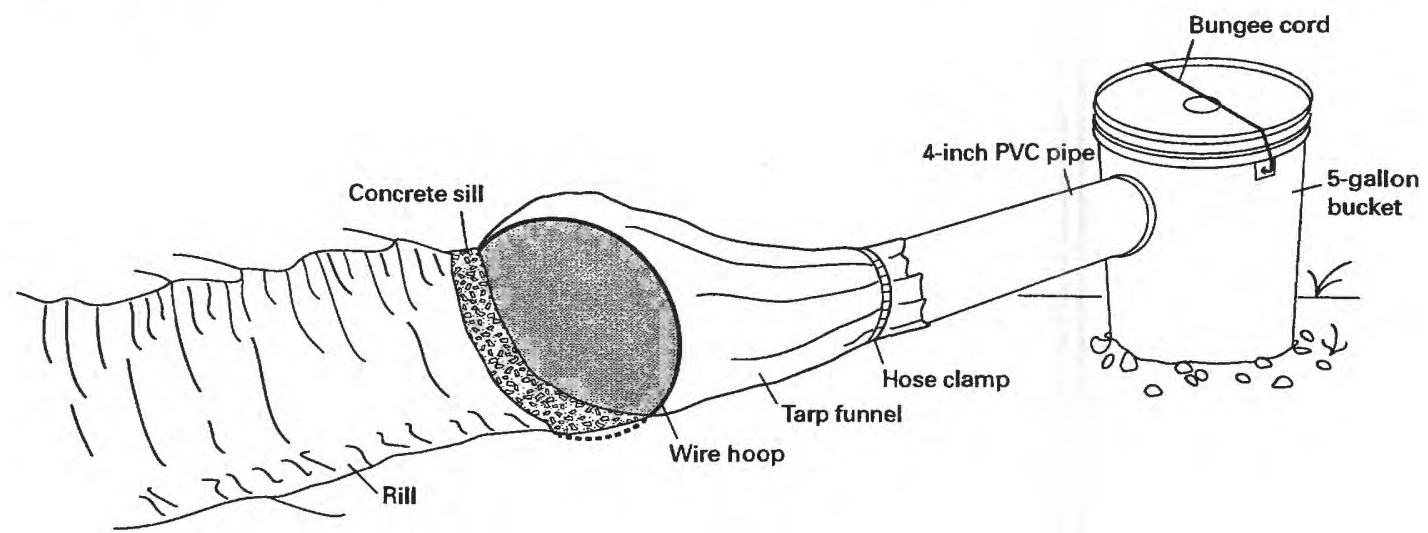

Figure 4.5. Rill trap. One end of the tarp was put under the concrete sill, which was flush with the bottom and sides of the rill. The tarp was folded over the wire hoop and secured with a screw through the folds to make a funnel. At the other end, the tarp was wrapped around the 4-inch PVC pipe and secured with a hose clamp. The 5-gallon bucket was identical to those used for the hillslope sediment traps and was linked to overflow buckets.

\section{Results}

\section{Interrill}

\section{Sediment Flux}

Estimates of the pre-fire erosion rates were made by measuring the summer sediment flux on north- and south-facing unburned hillslopes in 1998 and 1999 . The average flux was $0.14 \mathrm{~kg} /$ $\mathrm{m}$ (Martin and Moody, 2001) and was similar to sediment fluxes $(0.0-1.0 \mathrm{~kg} / \mathrm{m})$ measured in other unburned areas of the Colorado Front Range (Bovis, 1974; Morris, 1983; Morris and Moses, 1987; Welter, 1995). 
Measurements of interrill erosion rates during the first year after the wildfire (1997), indicated more sediment was eroded from north- than from south-facing severely burned hillslopes. The average sediment-flux rate during the summer of 1997 was $0.047 \mathrm{~kg} / \mathrm{m} / \mathrm{d}$ from north-facing and $0.0077 \mathrm{~kg} / \mathrm{m} / \mathrm{d}$ from south-facing hillslopes (table 4.5). These values are minimal estimates of the sediment flux because the 1997 study began in late July, missed the sediment transport by rainfall events in June and early July, and because the rainstorm on 31 August 1997 overwhelmed the sediment traps and only part of the eroded sediment was collected on the north-facing hillslope. The total sediment fluxes for the summer of 1997 ( $>5.7$ and $0.94 \mathrm{~kg} / \mathrm{m}$; table 4.5 and fig. 4.6) are similar to fluxes $(2.9-4.0 \mathrm{~kg} / \mathrm{m})$ reported by Morris and Moses (1987) within the first year after another wildfire in the Colorado Front Range.

Average interrill erosion rates on the north- and south-facing burned hillslopes decreased during the second, third, and fourth summers after the wildfire $(1998,1999$, and 2000). This decrease was not a result of less precipitation, because when the erosion is normalized by the rainfall, the severely burned north-facing slopes still produced significantly more sediment per millimeter of rainfall in 1997 than in 1998, 1999, or 2000 (fig. 4.6C). During the second summer (1998), the average sediment flux was $0.22 \mathrm{~kg} / \mathrm{m}$ or about twice the pre-fire erosion flux, and during the third and fourth summers after the wildfire, the average flux was 0.11 and $0.066 \mathrm{~kg} / \mathrm{m}$, similar to pre-fire erosion rates (table 4.5).

The flux of sediment from the north-facing, burned hillslope was greater than from the south-facing, burned hillslope through the summer of 1998. We hypothesize that the pre-fire vegetation density on the north-facing slope may account for this behavior. The fuel loading on the north-facing hillslopes (mainly densely spaced Douglas-fir with a thick litter and duff layer) was greater than on the south-facing hillslope and consequently the soils on the burned north-facing hillslopes were more water-repellent than on the south-facing hillslopes (Jeff Bruggink, written commun., 1997; for a more complete discussion of fire-induced water repellency see DeBano, 1969; Debano and other, 1977, and Giovannini and others, 1983). The greater water repellency on the north-facing, burned hillslopes probably created greater runoff that, in turn, caused greater erosion. Also, the thick litter and duff layer on the north-facing hillslopes probably held sediment that was easily mobilized once the litter and duff were burned (Peter Wohlgemuth, written commun., 1999). As herbaceous ground cover grows, the sediment is increasingly stabilized, and the runoff decreases leading to decreases in sediment flux.

\section{Particle-size Distribution}

Coarser particle sizes were collected in the runoff from the burned hillslopes during the summer of 1999 than during the summer of 1997 or 1998 . The median diameter $\left(D_{50}\right.$, tables 4.1 and 4.2) of the sediment collected from the runoff on the south-facing hillslope in 1999 ( $8.4 \mathrm{~mm})$ was larger than from the north-facing hillslopes $(4.1 \mathrm{~mm})$. Two hypotheses could explain the shift to coarser particle sizes. One hypothesis is that the coarsening may be the result of a diminished supply of the finer-grained material. Some of the finer material was eroded from the watershed during the 1996 storms after the wildfire, as evidenced by post-flood deposits of ash and finegrained sediment in Strontia Springs Reservoir and downstream from the Strontia Springs Dam. The erosion is also evident in 1997 , by the amount of fine sediment collected in the hillslope traps (see 1997 dashed curve in fig. 4.2A, tables 4.1-4.4). An alternative hypothesis is that there may be a preferential transport of coarser material with time after the wild fire, possibly by the dry ravel process (the transport of surface material by gravity and not by flowing water; Krammes, 1960,1965 ). In this climate, dry ravel is mainly triggered by wind and disturbance by fauna (deer, 
lizards, snakes, crickets, grasshoppers, and mice, some of which we inadvertently caught in our hillslope sediment traps). Field observations indicated that as the surfaces of both the unburned hillslopes and burned hillslopes dried out, it became increasingly difficult to walk on the surface without slipping and sliding because coarse-grained material ( $>4 \mathrm{~mm}$ diameter) was easily detached and rolled on the more cohesive fine-grained material which formed a hardened surface.

During each season, the eroded sediment from the south-facing, burned hillslope was coarser than the sediment from the north-facing, burned slope (fig. 4.6A). The relative coarseness of the eroded sediment from the burned south-facing hillslope compared with the north-facing, burned hillslopes and the unburned hillslopes may be a reflection of both the hillslope vegetation
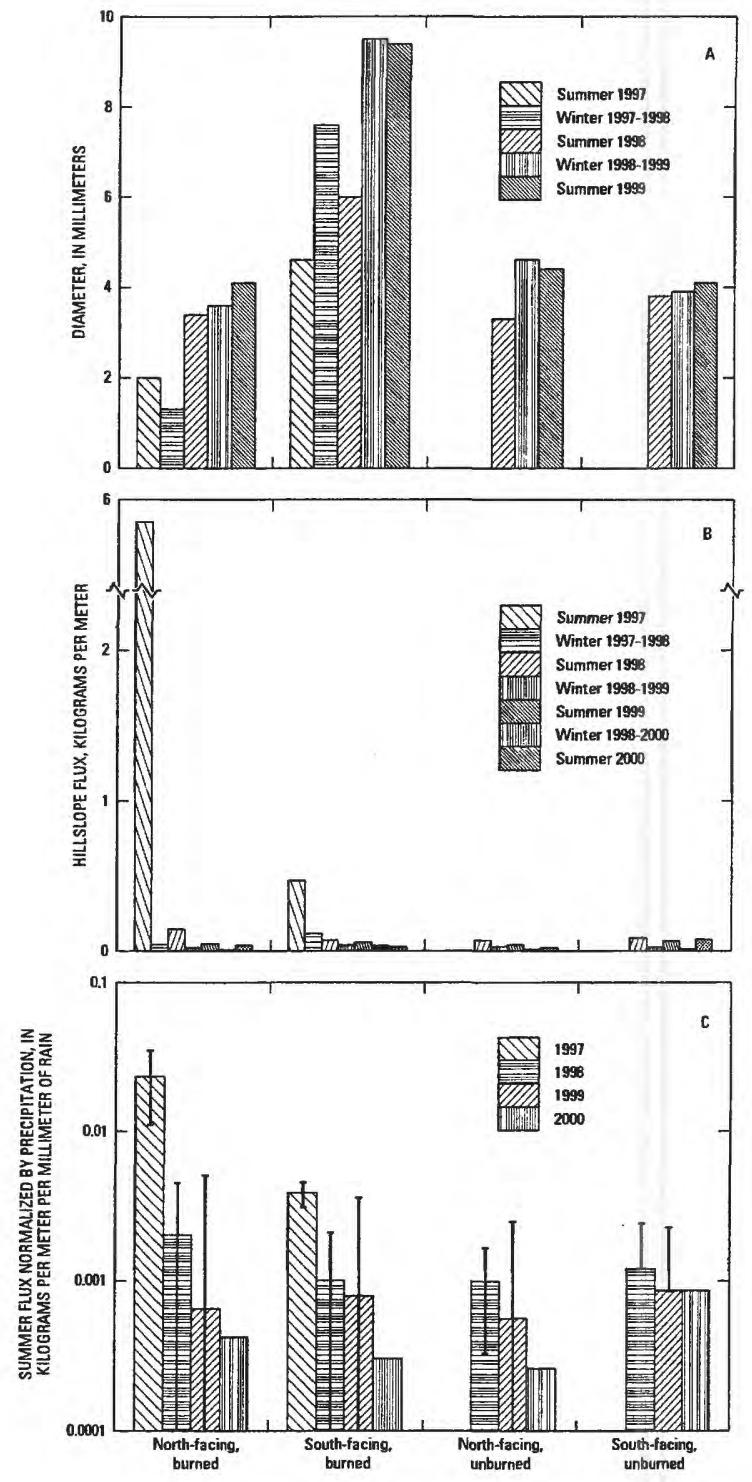

Figure 4.6. Seasonal change in median particle diameter and hillslope sediment flux in the Spring Creek watershed. A. Median particle diameter of eroded sediment collected in hillslope traps during summer (June-September, 122 days) and winter (October-May, 243 days) seasons. B. Hillslope flux for summer (June-September, 122 days) and winter (OctoberMay, 243 days) seasons. Hillslope traps were not deployed in the unburned area until 1998. C. Sediment flux normalized by the amount of rain during the collection interval. 
cover and the prior removal of some of the fine-grained sediment discussed above. On south-facing hillslopes, bunch grasses that existed before the wildfire have regrown. Even under unburned conditions, bare hillslopes are exposed between the bunch grasses. Field observations suggest that these spots without vegetation are more susceptible to dry ravel and disturbance than are the more vegetated hillslopes. The previous loss of the fine-grained material would reduce the soil cohesion and allow more coarse-grained material to erode. In contrast, the north-facing, burned hillslopes have developed a dense cover of herbaceous vegetation as they have recovered during the four years of our study. This vegetation cover on the recovering north-facing, burned hillslopes may be stabilizing the coarser-grained material.

\section{Rills}

Rills were found in the Spring Creek watershed on long hillslopes that had fewer obstructions than other slopes. Obstructions divert flow and provide frictional resistance; thus, a decrease in obstructions would decrease travel distance, and increase runoff velocity and shear stress. In general, south-facing hillslopes with lower tree density had more numerous and relatively larger rills than north-facing hillslopes. Hillslopes with rock outcrops or with a greater density of burnt trees and bushes had fewer rills because the length of the unobstructed surface was less and water running downhill was diverted many times by obstructions.

\section{Rill Geometry}

Rills in the Spring Creek watershed are hydraulic channels on planar or convex hillslopes. They were initially formed by unsteady flow during the 12 July 1996 rainstorm that probably lasted only a few hours. One major difference between these hydraulic channels and most streams and rivers, is the slope of the channel. These rills typically had channel slopes greater than 0.20 , compared with 0.04 and 0.02 for the Spring Creek and Buffalo Creek channels, and with 0.00001 for the Mississippi River at the other end of the spectrum of hydraulic channels (table 4.8). These slopes are also greater than agriculture and rangeland rills. The top widths are similar to agricultural rills, but the shape differs. The shape of hydraulic channels can be described by the relation:

$$
R=c A^{b},
$$

eq. 4.1

where $R$ is the hydraulic radius, $A$ is the cross-sectional area, and $c$ and $b$ are constants equal to 0.33 and 0.50 for a square channel. These constants depend on the width:depth ratio; for example, if a rectangular channel has a width:depth ratio of 0.20 , then $c=0.32$ and $b=0.25$. But if the ratio is 20 (typical of many rivers), then $c=0.02$ and $b=0.96$. The mean cross-sectional area for rills on south- and north-facing hillslopes in the Spring Creek watershed was $0.017 \mathrm{~m}^{2}$ and $0.022 \mathrm{~m}^{2}$, respectively (table 4.9 ). The value of $b$ for these rills was 0.55 , slightly greater than the value for a square channel, but less than values for rivers (table 4.8).

Cross-sectional area of rills was weakly related to the distance, $x$, downhill. For north-facing rills the relation was

$$
A=0.0014 x, r^{2}=0.25
$$

and for south-facing rills it was

$$
A=0.0080 x, r^{2}=0.23
$$


The low correlation coefficient is caused by the large variability (fig. 4.7) resulting from increases in cross-sectional area as rills flow over roots that create wide plunge pools and as rills flow over bed rock that prevent incision. For example, when the measurements for Rill A51 and Rill 4 are connected in downstream order (fig. 4.7), an oscillatory pattern is created with the maximum area occurring just downstream from a root.

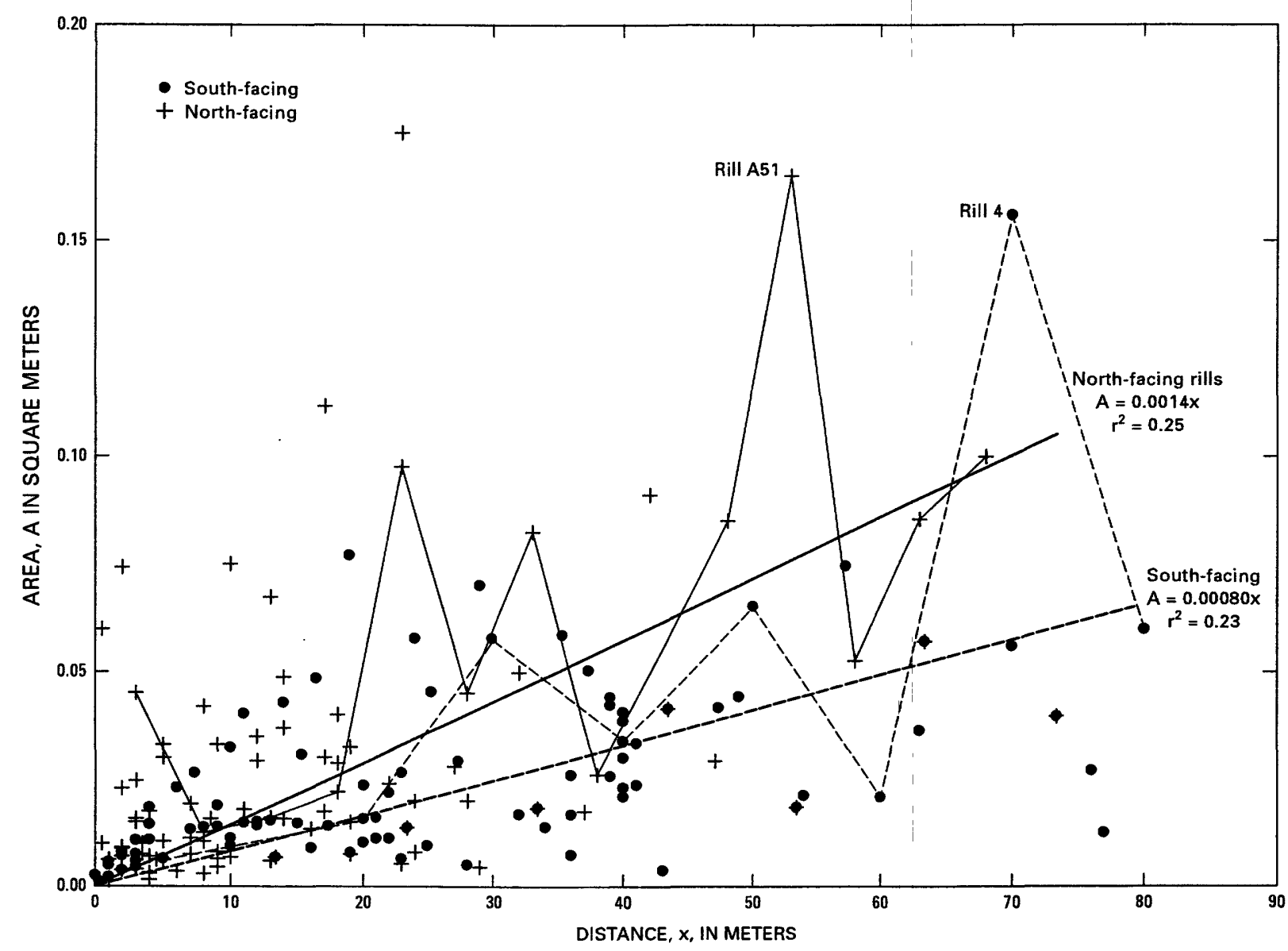

Figure 4.7. Cross-sectional area of rills in the Spring Creek watershed plotted as a function of distance from the beginning of the rills. Wide fluctuations, caused by roots and by shallow bedrock, are illustrated by connecting the measurements in Rill A51 by a lightweight solid line and those in Rill 4 by a short-dashed line. North-facing rills are shown by the plus symbols and south-facing rills are shown by solid circles.

\section{Rill Evolution}

Rills formed during the intense rainstorm on 12 July 1996. This conclusion is based on the examination of oblique photographs taken by the U. S. Forest Service (D. Bohon, oral commun., 1997) at the same location before and after the rainstorm. Monitoring of the rills started on 4 June 1998 and continued through 2000 . The average change in minimum bed elevation with time was computed for three cross sections on Rill A (sections 1, 2, and 3), Rill B (sections 5, 6, 
and 7), and Rill C (sections 11, 12, and 13). The minimum bed elevation increased during the first year as the bottom of the rills filled with 0.006 to $0.013 \mathrm{~m}$ of sediment (fig. 4.8 and 4.9). On 17 July 1999 a relatively intense rainstorm $\left(\mathrm{I}_{30}=18 \mathrm{~mm} / \mathrm{h}\right)$ localized near the rills, caused additional filling $(0.003 \mathrm{~m}$, from 0.013 to 0.016$)$ in Rill A but caused incision in Rill B $(0.032 \mathrm{~m}$, from 0.012 down to -0.020$)$ and in Rill C (0.030 m, from 0.006 down to -0.024). However, after the storm, all rills continued to fill. Rill B and Rill C filled more quickly than Rill A because sediment was deposited along the sides of the rills during the storm and was easily eroded during the months after the storm. An examination of some of the cross sections shown in figure 4.9 suggests that, in general, there was a corresponding lowering of the interrill area as rills filled.

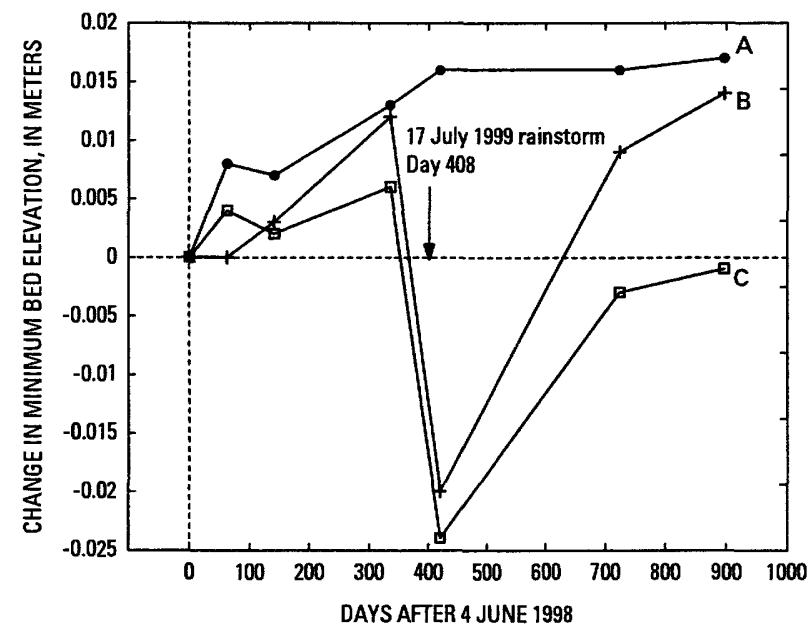

Figure 4.8. Change in minimum bed elevation of rills with time. Positive (negative) values represent aggradation (degradation) above (below) the minimum bed elevation for 4 June 1998. These values represent the average of three cross sections per rill.

Changes in rill widths and cross-sectional area with time were measured relative to an arbitrary reference elevation that was a fixed distance above the initial minimum bed elevation ( 4 June 1998) at each cross section. This reference elevation was $0.040 \mathrm{~m}, 0.050 \mathrm{~m}$, and $0.063 \mathrm{~m}$ above the minimum bed elevation for Rills A, B, and C, respectively. Widths and area were normalized by dividing by the initial values on 4 June 1998 and the average was computed for the three middle sections of each rill $(1,2,3$ for rill $\mathrm{A} ; 5,6,7$ for rill $\mathrm{B} ; 11,12,13$ for rill $\mathrm{C})$. At first, normalized widths increased slowly as the rills filled (fig. 4.10 ) by the processes of summer rainstorm erosion and winter freeze-thaw erosion of the side walls and deposition in the bottoms, where opportunistic plants like yellow evening-star (Mentzelia speciosa L., Huckaby, oral commun., 1999) sprouted and helped trap sediment. During the first year (3 measurements excluding 4 June 1998), the rills widened but filled so that the annual-average normalized area for all three rills remained nearly constant (1.03, fig. 4.11). Each rill responded differently after the 17 July 1999 rainstorm, perhaps because of the different distances downhill from the beginning of the rill at which cross sections were measured. Rill A widened and filled, so the normalized area changed little after the storm but fluctuated around 1.0 until 2000. Rill B narrowed (because sediment was deposited along the sides of the rill), but it also deepened slightly so that the change in area was also small after the storm. Rill $\mathrm{C}$ widened but also deepened so that the change in area was the largest. After the 17 July storm, the area decreased as the rill bottom filled with sediment (fig. 4.9). 

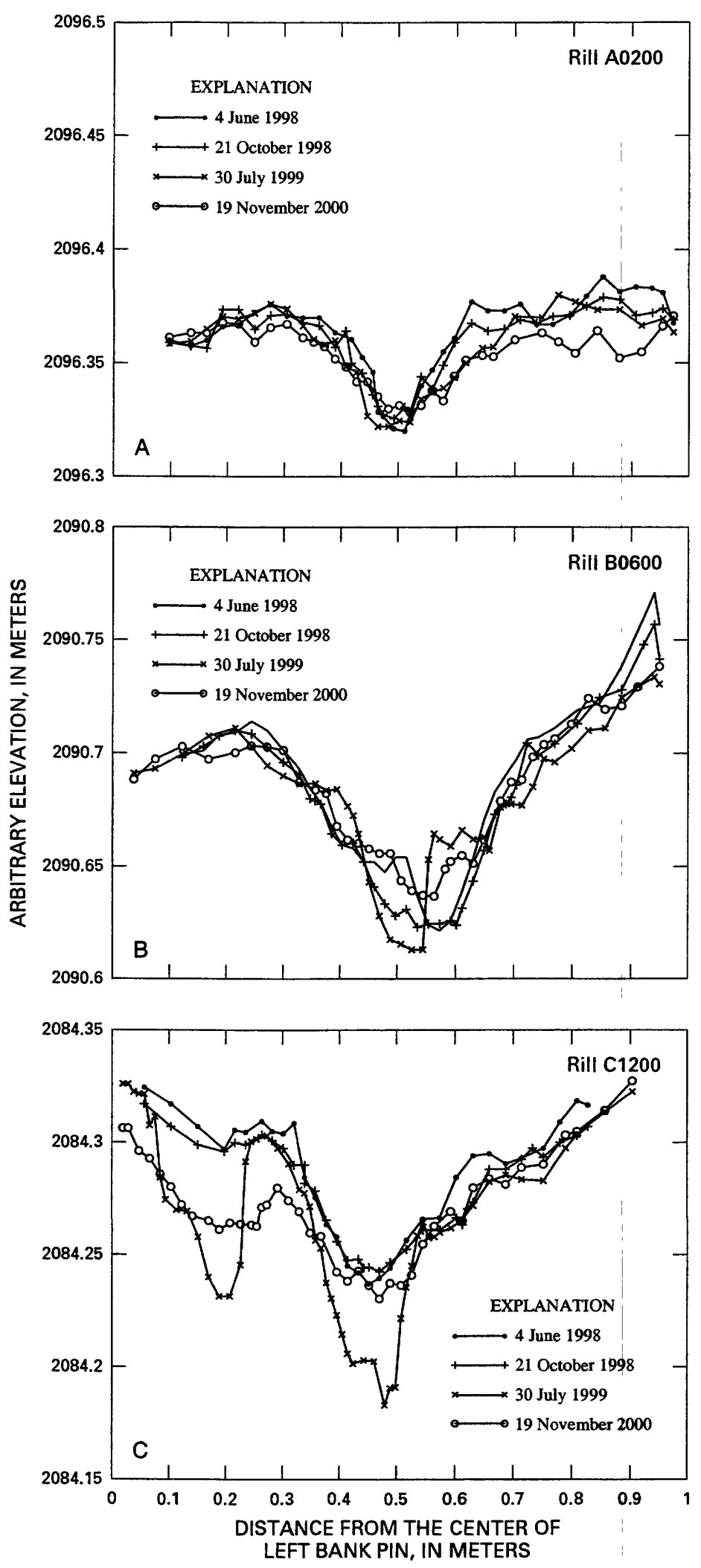

Figure 4.9. Change in rill profiles with time. A. Rill A, cross section 0200, B. Rill B, cross section 0600, and C. Rill C, cross section 1200. Left bank is determined by facing downslope. 


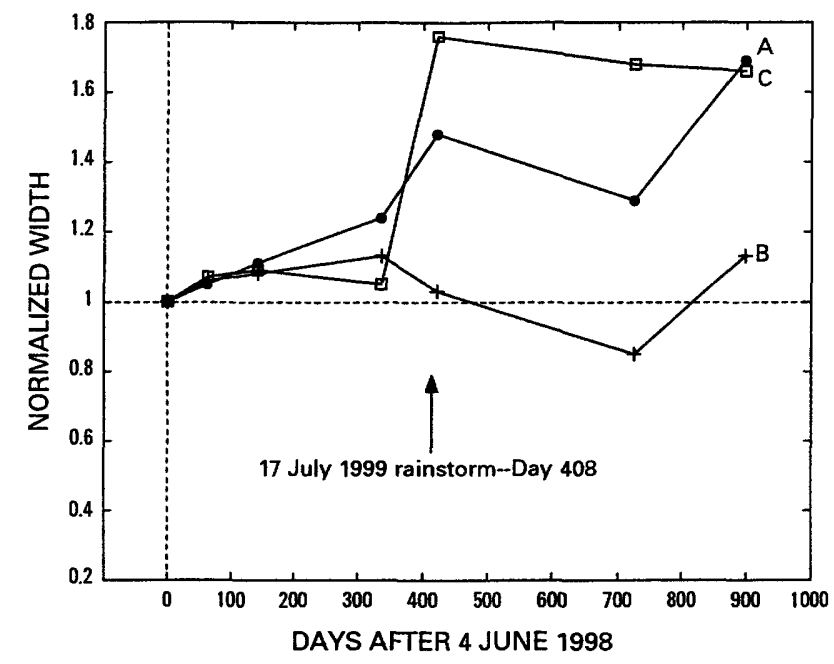

Figure 4.10. Change in normalized rill-width at a fixed elevation above the minimum bed elevation on 4 June 1998. These values are the average of three cross sections per rill.

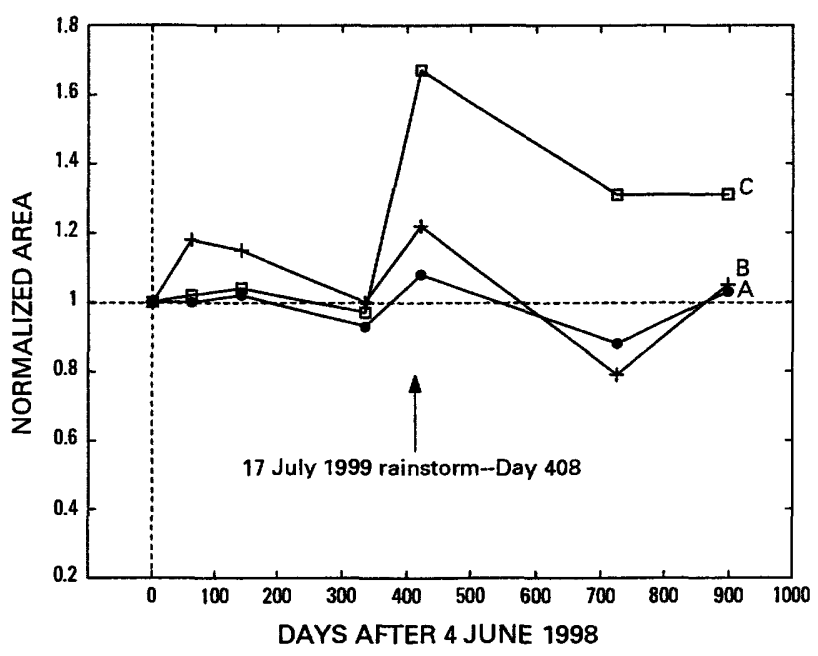

Figure 4.11. Change in normalized rill-area below a fixed elevation above the minimum bed elevation on 4 June 1998. These values are the average of three cross sections per rill.

\section{Rill Erosion}

Rill erosion during the first summer after the wildfire (1996) was estimated for north- and south-facing hillslopes. Mean rill length was estimated as the average length of overland flow (Horton, 1945) minus the length of the zone of no erosion starting at the hillslope ridge (about 5 $\mathrm{m})$. Average rill length was about $20 \mathrm{~m}$ in W960 and $5 \mathrm{~m}$ in W1165; and the average rill cross-sectional area was $0.020 \mathrm{~m}^{2}(\mathrm{n}=681)$ for rills in several north- and south-facing watersheds (table 
4.9). The number of rills that intersected a channel (some started and ended on a hillslope) in the two subwatersheds was similar (319 in W960 and 370 in W1165). Average rill spacing was about $10 \mathrm{~m}$ (some hillslopes in the watershed had no rills). Average rill top-width where the rill intersected a channel at the base of the hillslope was $0.36 \mathrm{~m}$ (this includes rills in watersheds other than W960 and W1165); thus, rills covered about 3.6 percent of the hillslope. Based on this information, the total volume of rill erosion was $100 \mathrm{~m}^{3}$ in the south-facing watershed (W960) and 40 $\mathrm{m}^{3}$ in the north-facing watershed (W1165).

No rill erosion was measured during 1997, and erosion rates for 1998, 1999, and 2000 are based on the three rill traps on a south-facing slope. Rill erosion rates increased rapidly when rain intensity exceeded about $30 \mathrm{~mm} / \mathrm{h}$. For example, the maximum sediment flux during the summer of 1998 was $0.36 \mathrm{~kg} / \mathrm{m}$ when rainfall intensities were less than $29 \mathrm{~mm} / \mathrm{h}$. But the maximum sediment flux $(22 \mathrm{~kg} / \mathrm{m})$ increased about 60 -fold during the summer of 1999 when the rainfall intensity was $35 \mathrm{~mm} / \mathrm{h}$. Estimates of the average sediment flux to the stream channels during the summer are based on these time-averaged fluxes, channel length in the burned areas, and the rill density ( 3.6 percent). Estimated sediment yield to the stream channels by rill erosion was $310 \mathrm{~m}^{3}$ in 1997 where we conservatively assumed the large rainstorm on 31 August 1997 produced rill erosion of the same order-of-magnitude as the rainstorm on 17 July 1999. Estimates of the average combined yields, to the channel of Buffalo and Spring Creeks, were $10 \mathrm{~m}^{3}, 310 \mathrm{~m}^{3}$, and 10 $\mathrm{m}^{3}$ in 1998,1999 , and 2000. 
Table 4.1. Summary of particle-size distribution and the flux of sediment into north-facing hillslope traps in a severely burned area of the Spring Creek watershed, 1997-2000

[mm, millimeter; $\mathrm{kg}$, kilogram; L, liter; $\mathrm{m}^{2}$, square meter; $\mathrm{kg} / \mathrm{m}$, kilogram per meter; $\mathrm{kg} / \mathrm{m} / \mathrm{d}$, kilogram per meter per day; days in parenthesis are the number of days between collection dates; $\mathrm{mm} / \mathrm{h}$, millimeter per hour; of, overflow; $\sim$, approximate; $\mathrm{I}_{30}$, maximum 30-minute rainfall intensity; $\mathrm{P}$, total rainfall; $\mathrm{I}_{30}$ and $\mathrm{P}$ calculated from data listed in U.S. Geological Survey 1997, 1998, 1999, and 2000; $\pm 95 \%$, 95-percent confidence limits; in 1997 the effective trap widths for traps $1,2,3$, and 4 , were $1.92,2.07,3.37$, and $3.38 \mathrm{~m}$, and in 1998-2000 the trap width was $1.00 \mathrm{~m}$ for all traps]

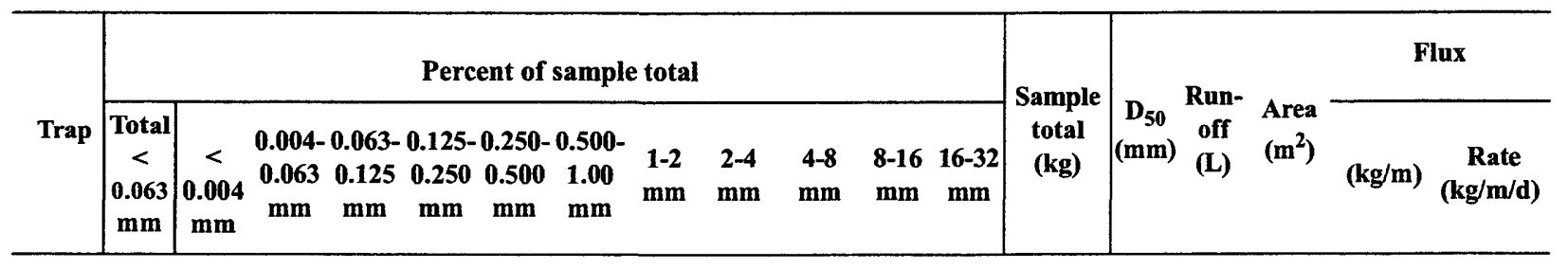

30 July 1997 ( 1 day; includes the storm on 29 July $1997 ; I_{30}=13.25 \mathrm{~mm} / \mathrm{h} ; P=7.1 \mathrm{~mm}$ )

\begin{tabular}{c|r|rrrrrrrrrrr|r|rrrrr}
1 & 32.7 & 10.0 & 22.7 & 6.2 & 6.3 & 7.1 & 7.9 & 11.7 & 16.7 & 9.8 & 1.6 & 0.0 & 0.185 & 0.4 & 9.9 & 6.90 & 0.096 & 0.096 \\
2 & 32.3 & 8.7 & 23.6 & 8.0 & 5.8 & 5.4 & 7.2 & 9.5 & 16.3 & 13.3 & 2.3 & 0.0 & 0.138 & 0.4 & 13.1 & 7.86 & 0.067 & 0.067 \\
3 & 26.0 & 6.2 & 19.8 & 4.9 & 6.1 & 7.2 & 9.3 & 14.7 & 18.3 & 12.3 & 1.1 & 0.0 & 0.346 & 0.8 & 16.8 & 14.98 & 0.10 & 0.10 \\
4 & 13.2 & 4.1 & 9.1 & 4.3 & 2.7 & 4.4 & 8.3 & 13.0 & 23.0 & 24.2 & 6.9 & 0.0 & 0.146 & 2.4 & 7.5 & 14.52 & 0.043 & 0.043 \\
Mean & 26.0 & 7.2 & 18.8 & 5.8 & 5.2 & 6.0 & 8.2 & 12.2 & 18.6 & 14.9 & 3.0 & 0.0 & 0.204 & 1.0 & 11.8 & -- & 0.076 & 0.076 \\
$\pm 95 \%$ & 14.0 & 4.2 & 10.4 & 2.7 & 2.6 & 2.0 & 1.5 & 3.7 & 4.8 & 10.4 & 4.2 & 0.0 & 0.150 & 1.4 & 6.7 & - & 0.041 & 0.041
\end{tabular}

8 August 1997 ( 9 days; $I_{30}=24.00 \mathrm{~mm} / \mathrm{h} ; P=41.1 \mathrm{~mm}$ )

\begin{tabular}{c|r|ccccccccccc|c|ccccc}
1 & 19.0 & 4.2 & 14.8 & 8.6 & 6.8 & 6.7 & 9.0 & 13.3 & 20.3 & 14.7 & 1.7 & 0.0 & 0.550 & 1.0 & of & 6.90 & 0.29 & 0.032 \\
2 & 14.7 & 1.8 & 12.9 & 9.4 & 6.4 & 7.2 & 10.1 & 13.4 & 19.2 & 19.2 & 0.6 & 0.0 & 0.155 & 1.2 & of & 7.86 & 0.075 & 0.0083 \\
3 & 10.7 & - & - & 5.3 & 6.2 & 7.3 & 10.0 & 16.9 & 24.4 & 17.5 & 1.6 & 0.0 & 1.623 & 1.6 & of & 14.98 & 0.48 & 0.054 \\
4 & 7.1 & 1.3 & 5.8 & 2.9 & 3.8 & 5.3 & 8.0 & 14.8 & 25.2 & 28.0 & 5.0 & 0.0 & 0.350 & 2.6 & of & 14.52 & 0.10 & 0.012 \\
Mean & 12.9 & - & - & 6.6 & 5.8 & 6.6 & 9.3 & 14.6 & 22.3 & 19.8 & 2.2 & 0.0 & 0.670 & 1.6 & - & - & 0.24 & 0.026 \\
$\pm 95 \%$ & 8.6 & - & - & 4.7 & 2.2 & 1.4 & 1.5 & 2.6 & 4.3 & 9.6 & 3.2 & 0.0 & 1.057 & 1.2 & - & - & 0.29 & 0.033
\end{tabular}

14 August $1997\left(6\right.$ days; $I_{30}=9.75 \mathrm{~mm} / \mathrm{h} ; P=18.8 \mathrm{~mm}$ )

\begin{tabular}{c|r|rrrrrrrrrrr|r|rrrrr}
1 & 35.8 & 11.1 & 24.7 & 4.4 & 3.7 & 5.3 & 6.3 & 9.9 & 16.6 & 17.5 & 0.6 & 0.0 & 0.186 & 0.6 & 20.1 & 6.90 & 0.097 & 0.016 \\
2 & 24.3 & 7.2 & 17.1 & 3.2 & 2.3 & 3.4 & 5.4 & 8.2 & 19.0 & 27.8 & 6.4 & 0.0 & 0.125 & 2.3 & 15.7 & 7.86 & 0.060 & 0.010 \\
3 & 15.6 & 4.2 & 11.4 & 3.4 & 3.5 & 5.1 & 7.4 & 14.1 & 24.3 & 21.0 & 5.4 & 0.0 & 0.328 & 2.1 & 19.6 & 14.98 & 0.097 & 0.016 \\
4 & 3.2 & 2.1 & 1.1 & 1.2 & 1.3 & 2.3 & 4.4 & 9.6 & 20.4 & 36.7 & 18.5 & 2.4 & 0.234 & 4.8 & 14.3 & 14.52 & 0.069 & 0.012 \\
Mean & 19.7 & 6.2 & 13.6 & 3.0 & 2.7 & 4.0 & 5.9 & 10.4 & 20.0 & 25.8 & 7.7 & 0.6 & 0.218 & 2.4 & 17.4 & -- & 0.081 & 0.014 \\
$\pm 95 \%$ & 23.5 & 6.5 & 17.0 & 2.3 & 1.7 & 2.2 & 2.2 & 4.2 & 5.5 & 13.8 & 12.9 & 1.7 & 0.146 & 3.0 & 4.2 & - & 0.027 & 0.004
\end{tabular}

18 August 1997 (4 days; $I_{30}=3.00 \mathrm{~mm} / \mathrm{h} ; P=4.8 \mathrm{~mm}$ )

\begin{tabular}{|c|c|c|c|c|c|c|c|c|c|c|c|c|c|c|c|c|c|c|}
\hline 1 & 7.4 & - & - & 2.3 & 1.4 & 3.7 & 8.4 & 16.7 & 21.4 & 19.5 & 19.1 & 0.0 & 0.021 & 3.0 & 0.9 & 6.90 & 0.011 & 0.0029 \\
\hline 2 & 6.0 & -- & - & 3.4 & 2.5 & 6.8 & 11.9 & 19.5 & 16.1 & 9.3 & 24.6 & 0.0 & 0.012 & 2.0 & 0.6 & 7.86 & 0.0058 & 0.0014 \\
\hline 3 & 3.4 & - & - & 2.0 & 2.9 & 6.2 & 11.7 & 20.2 & 23.4 & 21.5 & 8.5 & 0.0 & 0.031 & 2.3 & 0.6 & 14.98 & 0.0092 & 0.0023 \\
\hline 4 & 2.3 & -- & -- & 1.6 & 2.2 & 5.5 & 13.1 & 23.0 & 27.9 & 12.6 & 12.0 & 0.0 & 0.018 & 2.2 & 0.7 & 14.52 & 0.0053 & 0.0013 \\
\hline Mean & 4.8 & & & 2.3 & 2.2 & 5.6 & 11.3 & 19.9 & 22.2 & 15.7 & 16.0 & 0.0 & 0.021 & 2.4 & 0.7 & - & 0.0078 & 0.0020 \\
\hline $5 \%$ & 3.7 & & & 1.3 & 1.1 & 2.2 & 3.4 & 4.5 & 8.5 & 8.8 & 11.6 & 0.0 & 0.014 & 0.7 & 0.2 & -- & 0.0041 & 0.0012 \\
\hline \multicolumn{19}{|c|}{20 August $1997\left(2\right.$ days; $\left.I_{30}=5.00 \mathrm{~mm} / \mathrm{h} ; P=2.8 \mathrm{~mm}\right)$} \\
\hline 1 & 3.3 & - & -- & 2.6 & 2.6 & 5.3 & 9.9 & 19.7 & 28.3 & 22.4 & 5.9 & 0.0 & 0.015 & 2.5 & 1.2 & 6.90 & 0.0078 & 0.0039 \\
\hline 2 & 5.6 & -- & -- & 4.7 & 3.2 & 5.6 & 9.5 & 15.9 & 32.5 & 23.0 & 0.0 & 0.0 & 0.013 & 2.3 & 0.7 & 7.86 & 0.0063 & 0.0031 \\
\hline 3 & 1.5 & -- & -- & 2.0 & 3.0 & 7.0 & 12.1 & 25.6 & 35.7 & 13.1 & 0.0 & 0.0 & 0.020 & 2.0 & 0.4 & 14.98 & 0.0059 & 0.0030 \\
\hline 4 & 5.8 & -. & - & 1.9 & 1.5 & 4.4 & 9.7 & 17.5 & 26.7 & 32.5 & 0.0 & 0.0 & 0.021 & 2.7 & 0.9 & 14.52 & 0.0062 & 0.0031 \\
\hline lear & 4.0 & - & - & 2.8 & 2.6 & 5.6 & 10.3 & 19.7 & 30.8 & 22.8 & 1.5 & 0.0 & 0.017 & 2.4 & 0.8 & - & 0.0066 & 0.0033 \\
\hline $95 \%$ & 3.1 & -- & - & 2.0 & 1.2 & 1.9 & 1.9 & 7.0 & 6.5 & 14.0 & 4.2 & 0.0 & 0.006 & 0.5 & 0.6 & - & 0.0014 & 0.00065 \\
\hline
\end{tabular}


Table 4.1. (Continued) Summary of particle-size distribution and the flux of sediment into north-facing hillslope traps in a severely burned area of the Spring Creek watershed, 1997-2000

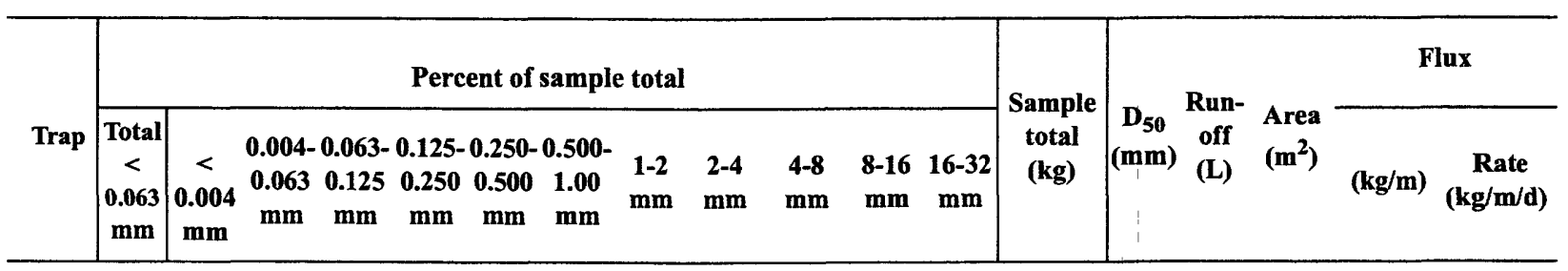

31 August 1997 (11 days; $\left.I_{30}=11.25 \mathrm{~mm} / \mathrm{h} ; 13.7 \mathrm{~mm}\right)$

\begin{tabular}{c|r|rrrrrrrrrrr|r|rrrrr}
1 & 39.4 & 12.1 & 27.3 & 4.5 & 4.6 & 5.7 & 6.9 & 10.2 & 14.1 & 14.1 & 0.4 & 0.0 & 0.199 & 0.3 & 17.8 & 6.90 & 0.10 & 0.0094 \\
2 & 36.9 & 18.4 & 18.5 & 5.2 & 3.2 & 5.1 & 8.0 & 10.8 & 16.1 & 12.0 & 2.7 & 0.0 & 0.078 & 0.5 & 13.4 & 7.86 & 0.038 & 0.0034 \\
3 & 8.0 & -- & -- & 5.0 & 5.9 & 7.5 & 11.0 & 20.1 & 26.9 & 15.2 & 0.3 & 0.0 & 0.291 & 1.6 & of & 14.98 & 0.086 & 0.0078 \\
4 & 15.8 & - & -- & 2.5 & 2.6 & 4.8 & 9.4 & 14.8 & 20.5 & 23.0 & 6.6 & 0.0 & 0.128 & 2.0 & 11.9 & 14.52 & 0.036 & 0.0033 \\
Mean & 25.0 & -- & -- & 4.3 & 4.1 & 5.8 & 8.8 & 14.0 & 19.4 & 16.1 & 2.5 & 0.0 & 0.172 & 1.1 & -- & -- & 0.065 & 0.0060 \\
$\pm 95 \%$ & 22.6 & -- & -- & 1.9 & 2.4 & 1.9 & 3.0 & 7.1 & 9.2 & 7.9 & 4.5 & 0.0 & 0.153 & 1.2 & -- & -- & 0.046 & 0.0043
\end{tabular}

4 September 1997 (traps overflowed; totals are minimum estimates; duration was rounded to 1 day; $I_{30}=88.00 \mathrm{~mm} / \mathrm{h} ; P=51.3 \mathrm{~mm}$ )

\begin{tabular}{|c|c|c|c|c|c|c|c|c|c|c|c|c|c|c|c|c|c|c|}
\hline 1 & 6.8 & -- & $\cdots$ & 3.6 & 4.0 & 5.8 & 7.8 & 13.8 & 22.4 & 24.3 & 10.2 & 1.3 & $>5.865$ & 2.7 & of & 6.90 & $>3.0$ & $>3.0$ \\
\hline 2 & 4.6 & -- & -- & 2.6 & 3.1 & 4.8 & 7.0 & 12.9 & 21.4 & 25.8 & 14.2 & 3.6 & $>9.288$ & 3.4 & of & 7.86 & $>4.5$ & $>4.5$ \\
\hline 3 & 3.6 & - & - & 2.6 & 3.8 & 5.2 & 7.2 & 13.3 & 23.4 & 27.7 & 12.2 & $0.7^{\mathrm{a}}$ & 14.889 & 3.2 & of & 14.98 & $>4.4$ & $>4.4$ \\
\hline 4 & 2.6 & -- & -- & 1.5 & 2.0 & 3.7 & 6.2 & 12.4 & 23.2 & 29.8 & 16.1 & 2.5 & $>3.969$ & 3.9 & of & 14.52 & $>1.2$ & $>1.2$ \\
\hline Mean & 4.4 & - & -- & 2.6 & 3.2 & 4.9 & 7.0 & 13.1 & 22.6 & 26.9 & 13.2 & 2.0 & -- & 3.3 & - & -- & $>3.3$ & $>3.3$ \\
\hline $5 \%$ & 3.0 & - & -. & 1.5 & 1.4 & 1.5 & 1.2 & 1.0 & 1.4 & 4.0 & 4.2 & 2.1 & -- & 0.9 & _ & - & NA & NA \\
\hline \multicolumn{19}{|c|}{15 September $1997\left(11\right.$ days; $\left.I_{30}=13.75 \mathrm{~mm} / \mathrm{h} ; P=8.4 \mathrm{~mm}\right)$} \\
\hline 1 & 16.1 & -- & -- & 7.5 & 7.7 & 9.3 & 11.8 & 15.4 & 17.8 & 11.5 & 2.9 & 0.0 & 0.602 & 0.9 & of & 6.90 & 0.31 & 0.028 \\
\hline 2 & 20.3 & 4.9 & 15.4 & 5.2 & 6.1 & 8.5 & 12.1 & 16.5 & 20.8 & 8.2 & 2.1 & 0.0 & 0.596 & 0.9 & 16.6 & 7.86 & 0.29 & 0.026 \\
\hline 3 & 19.6 & - & -- & 1.8 & 6.1 & 7.0 & 8.2 & 14.2 & 22.6 & 16.3 & 4.2 & 0.0 & 0.389 & 1.5 & of & 14.98 & 0.12 & 0.010 \\
\hline 4 & 5.7 & 0.8 & 4.9 & 2.0 & 2.4 & 3.5 & 7.0 & 12.6 & 24.7 & 30.7 & 11.6 & 0.0 & 0.204 & 3.4 & 7.4 & 14.52 & 0.060 & 0.0055 \\
\hline Jean & 15.4 & -- & -- & 4.1 & 5.6 & 7.1 & 9.8 & 14.7 & 21.5 & 16.7 & 5.2 & 0.0 & 0.448 & 1.7 & & - & 0.20 & 0.017 \\
\hline $5 \%$ & .5 & -- & -- & 4.1 & 3.8 & 4.2 & 3.7 & 2.8 & 5.0 & 16.2 & 6.8 & 0.0 & 0.287 & 1.8 & & -- & 0.18 & 0.016 \\
\hline \multicolumn{19}{|c|}{2 October $1997\left(17\right.$ days; $\left.I_{30}=5.00 \mathrm{~mm} / \mathrm{h} ; P=7.9 \mathrm{~mm}\right)$} \\
\hline 1 & 31.9 & -- & -- & 3.9 & 5.3 & 8.7 & 9.7 & 10.1 & 6.3 & 7.7 & 16.4 & 0.0 & 0.021 & 0.5 & 6.0 & 6.90 & 0.011 & 0.00064 \\
\hline 2 & 17.7 & -- & - & 2.8 & 5.7 & 11.4 & 17.7 & 19.2 & 17.7 & 7.8 & 0.0 & 0.0 & 0.014 & 0.9 & 2.4 & 7.86 & 0.0068 & 0.00040 \\
\hline 3 & 22.4 & -- & -- & 3.5 & 2.1 & 6.3 & 11.2 & 14.7 & 21.7 & 7.7 & 10.5 & 0.0 & 0.014 & 1.3 & $\sim 2.8$ & 14.98 & 0.0042 & 0.00024 \\
\hline 4 & 23.2 & -- & -- & 0.9 & 2.8 & 6.5 & 12.0 & 13.9 & 15.7 & 15.7 & 9.3 & 0.0 & 0.011 & 1.3 & $\sim 3.0$ & 14.52 & 0.0032 & 0.00019 \\
\hline Mean & 23.8 & - & - & 2.7 & 4.0 & 8.2 & 12.6 & 14.5 & 15.4 & 9.7 & 9.0 & 0.0 & 0.015 & 1.0 & $\sim 4$ & - & 0.0063 & 0.00037 \\
\hline$=95 \%$ & 10.2 & -- & -- & 2.2 & 2.6 & 3.7 & 5.8 & 6.6 & 11.1 & 5.8 & 11.8 & 0.0 & 0.007 & 0.6 & $\sim 3$ & -- & 0.0056 & 0.00033 \\
\hline \multicolumn{19}{|c|}{16 June $1998\left(11\right.$ days; $\left.I_{30}=13.75 \mathrm{~mm} / \mathrm{h} ; P=14.7 \mathrm{~mm}\right)$} \\
\hline 1 & 0.3 & -- & -- & 0.9 & 1.6 & 3.1 & 6.4 & 10.0 & 13.5 & 64.2 & 0.0 & 0.0 & 0.030 & 4.9 & 2.0 & 5.0 & 0.030 & 0.0027 \\
\hline 2 & 1.6 & -- & -- & 2.3 & 3.0 & 5.5 & 12.7 & 22.1 & 37.2 & 15.6 & 0.0 & 0.0 & 0.021 & 2.2 & 1.7 & 5.0 & 0.021 & 0.0019 \\
\hline 3 & 0.4 & -- & -- & 0.9 & 1.6 & 2.9 & 6.3 & 11.9 & 27.5 & 48.6 & 0.0 & 0.0 & 0.059 & 3.9 & 1.6 & 5.0 & 0.059 & 0.0054 \\
\hline 4 & 0.2 & -- & -- & 0.4 & 0.8 & 1.6 & 3.6 & 6.8 & 17.5 & 68.9 & 0.0 & 0.0 & 0.104 & 5.1 & 2.1 & 5.0 & 0.10 & 0.0094 \\
\hline S & 0.6 & - & -- & 1.1 & 1.8 & 3.3 & 7.2 & 12.7 & 23.9 & 49.3 & 0.0 & 0.0 & 0.054 & 4.0 & 1.8 & - & 0.052 & 0.0048 \\
\hline$=95 \%$ & 1.0 & -- & -- & 1.4 & 1.6 & 2.9 & 6.6 & 11.0 & 17.1 & 38.4 & 0.0 & 0.0 & 0.060 & 2.2 & 0.4 & -- & 0.058 & 0.0054 \\
\hline
\end{tabular}


Table 4.1. (Continued) Summary of particle-size distribution and the flux of sediment into north-facing hillslope traps in a severely burned area of the Spring Creek watershed, 1997-2000

\begin{tabular}{|c|c|c|c|c|c|c|c|c|c|c|c|c|c|c|c|c|c|}
\hline \multirow{2}{*}{ Trap } & \multicolumn{11}{|c|}{ Percent of sample total } & \multirow{2}{*}{$\begin{array}{c}\text { Sample } \\
\text { total } \\
(\mathrm{kg})\end{array}$} & \multirow{2}{*}{$\begin{array}{c}D_{50} \\
(\mathbf{m m})\end{array}$} & \multirow{2}{*}{$\begin{array}{c}\text { Run- } \\
\text { off } \\
\text { (L) }\end{array}$} & \multirow{2}{*}{$\begin{array}{l}\text { Area } \\
\left(\mathbf{m}^{2}\right)\end{array}$} & \multicolumn{2}{|c|}{ Flux } \\
\hline & $\mid \begin{array}{c}< \\
< \\
0.063 \\
\mathrm{~mm}\end{array}$ & $\begin{array}{c}< \\
0.004 \\
\mathrm{~mm}\end{array}$ & $\begin{array}{cc}0.004-0.063 \\
0.063 & 0.125 \\
\mathrm{~mm} & \mathrm{~mm}\end{array}$ & $\begin{array}{c}0.125 \\
0.250 \\
\mathrm{~mm}\end{array}$ & $\begin{array}{c}0.250 \\
0.500 \\
\mathrm{~mm}\end{array}$ & $\begin{array}{c}-0.500- \\
1.00 \\
\mathrm{~mm}\end{array}$ & $\begin{array}{c}1-2 \\
\mathrm{~mm}\end{array}$ & $\begin{array}{l}2-4 \\
\text { mm }\end{array}$ & $\begin{array}{l}4-8 \\
\mathrm{~mm}\end{array}$ & $\begin{array}{l}\text { 8-16 } \\
\text { mm }\end{array}$ & $\begin{array}{c}16-32 \\
\mathrm{~mm}\end{array}$ & & & & & $(\mathrm{~kg} / \mathrm{m})$ & $\begin{array}{c}\text { Rate } \\
(\mathrm{kg} / \mathrm{m} / \mathrm{d})\end{array}$ \\
\hline
\end{tabular}

11 July 1998 (25 days; $I_{30}=7.50 \mathrm{~mm} / \mathrm{h}^{\mathrm{b}} ; P=21.1 \mathrm{~mm}$ )

\begin{tabular}{|c|c|c|c|c|c|c|c|c|c|c|c|c|c|c|c|c|c|c|}
\hline & & & & & & & & & & & & & & & & & & \\
\hline 1 & 1.2 & -- & - & 2.4 & 3.7 & 6.1 & 9.8 & 9.8 & 6.1 & 3.7 & 57.3 & 0.0 & 0.008 & 9.0 & 2.0 & 5.0 & 0.008 & 0.00032 \\
\hline 2 & 3.2 & -- & -- & 3.2 & 3.2 & 11.6 & 19.0 & 25.3 & 24.2 & 10.5 & 0.0 & 0.0 & 0.010 & 1.4 & 1.9 & 5.0 & 0.010 & 0.00040 \\
\hline 3 & 1.3 & - & -- & 2.5 & 4.4 & 7.0 & 12.7 & 21.5 & 22.2 & 12.0 & 16.5 & 0.0 & 0.016 & 2.0 & 1.8 & 5.0 & 0.016 & 0.00064 \\
\hline 4 & 0.9 & -- & -- & 0.9 & 1.4 & 5.1 & 6.5 & 11.2 & 18.6 & 25.6 & 29.8 & 0.0 & 0.022 & 4.8 & 2.5 & 5.0 & 0.022 & 0.00088 \\
\hline Mean & 1.6 & - & -- & 2.2 & 3.2 & 7.4 & 12.0 & 17.0 & 17.8 & 13.0 & 25.9 & 0.0 & 0.014 & 4.3 & 2.0 & - & 0.014 & 0.00056 \\
\hline $\pm 95 \%$ & 1.7 & -- & - & 1.7 & 2.2 & 4.7 & 9.0 & 11.2 & 13.0 & 15.8 & 41.3 & 0.0 & 0.010 & 5.5 & 0.5 & -- & 0.010 & 0.00040 \\
\hline \multicolumn{19}{|c|}{4 August $1998\left(24\right.$ days; $\left.I_{30}=28.50 \mathrm{~mm} / \mathrm{h} ; P=69.1 \mathrm{~mm}\right)$} \\
\hline 1 & 4.8 & 0.1 & 4.7 & 3.5 & 4.5 & 9.6 & 15.3 & 17.8 & 23.1 & 21.4 & 0.0 & 0.0 & 0.040 & 1.7 & 9.2 & 5.0 & 0.040 & 0.0017 \\
\hline 2 & 4.4 & 0.1 & 4.3 & 2.8 & 4.6 & 8.6 & 12.7 & 20.0 & 32.1 & 14.9 & 0.0 & 0.0 , & 0.054 & 1.8 & 4.1 & 5.0 & 0.054 & 0.0022 \\
\hline 3 & 3.3 & 0.1 & 3.2 & 2.9 & 2.4 & 5.3 & 8.9 & 15.7 & 21.6 & 20.3 & 8.8 & 10.9 & 0.119 & 3.1 & 4.2 & 5.0 & 0.12 & 0.0050 \\
\hline 4 & 0.8 & -- & -. & 0.8 & 1.9 & 4.3 & 7.0 & 14.2 & 26.9 & 33.3 & 10.9 & 0.0 & 0.119 & 3.6 & 8.2 & 5.0 & 0.12 & 0.0050 \\
\hline Mean & 3.3 & - & -. & 2.5 & 3.4 & 7.0 & 11.0 & 16.9 & 25.9 & 22.5 & 4.9 & 2.7 & 0.083 & 2.6 & 6.4 & - & 0.084 & 0.0035 \\
\hline $\pm 95 \%$ & 2.9 & -- & - & 1.9 & 1.9 & 3.8 & 6.0 & 4.2 & 7.6 & 13.2 & 7.8 & 7.8 & 0.057 & 1.4 & 3.7 & - & 0.058 & 0.0024 \\
\hline \multicolumn{19}{|c|}{9 September 1998 ( 36 days; $I_{30}=14.75 \mathrm{~mm} / \mathrm{h} ; P=36.1 \mathrm{~mm}$ ) } \\
\hline 1 & 4.4 & -- & -- & 0.6 & 1.8 & 5.3 & 8.6 & 15.2 & 20.7 & 28.4 & 15.1 & 0.0 & 0.018 & 3.4 & 5.1 & 5.0 & 0.018 & 0.00050 \\
\hline 2 & 2.7 & - & - & 2.4 & 4.9 & 9.7 & 14.6 & 23.6 & 35.6 & 6.5 & 0.0 & 0.0 & 0.019 & 1.7 & 3.1 & 5.0 & 0.019 & 0.00053 \\
\hline 3 & 4.9 & -- & - & 0.4 & 1.9 & 5.9 & 9.6 & 16.1 & 24.0 & 29.6 & 7.8 & 0.0 & 0.043 & 2.9 & 3.7 & 5.0 & 0.043 & 0.0012 \\
\hline 4 & 0.5 & -- & -- & 0.5 & 1.4 & 3.4 & 9.2 & 8.7 & 27.9 & 31.6 & 16.8 & 0.0 & 0.056 & 3.9 & 4.3 & 5.0 & 0.056 & 0.0016 \\
\hline Mean & 3.1 & - & - & 1.0 & 2.5 & 6.1 & 10.5 & 15.9 & 27.0 & 24.0 & 9.9 & 0.0 & 0.034 & 3.0 & 4.0 & -- & 0.034 & 0.00096 \\
\hline $\pm 95 \%$ & 3.2 & - & -- & 1.4 & 2.5 & 4.5 & 4.3 & 10.7 & 10.7 & 18.1 & 12.1 & 0.0 & 0.027 & 1.6 & 1.4 & - & 0.027 & 0.00079 \\
\hline \multicolumn{19}{|c|}{26 May 1999 (259 days; rain gage was not maintained during part of collection interval) } \\
\hline 1 & 7.8 & - & -- & 6.8 & 3.8 & 11.5 & 14.8 & 14.8 & 10.7 & 17.2 & 12.5 & 0.0 & 0.017 & 1.4 & c & 5.0 & 0.017 & 0.000066 \\
\hline 2 & 5.8 & - & - & 6.9 & 3.1 & 10.8 & 16.8 & 28.0 & 28.7 & 0.0 & 0.0 & 0.0 & 0.020 & 1.2 & c & 5.0 & 0.020 & 0.000077 \\
\hline 3 & 1.4 & - & - & 0.8 & 1.8 & 3.2 & 5.7 & 10.4 & 14.3 & 23.6 & 38.9 & 0.0 & 0.055 & 6.1 & c & 5.0 & 0.055 & 0.00021 \\
\hline 4 & 1.0 & - & -- & 0.5 & 1.1 & 2.1 & 3.9 & 8.4 & 18.4 & 35.3 & 19.9 & 9.5 & 0.140 & 5.7 & c & 5.0 & 0.140 & 0.00054 \\
\hline Mean & 4.0 & - & -- & 3.8 & 2.4 & 6.9 & 10.3 & 15.4 & 18.0 & 19.0 & 17.8 & 2.4 & 0.058 & 3.6 & - & - & 0.058 & 0.00022 \\
\hline $\pm 95 \%$ & 4.9 & -- & - & 4.6 & 1.9 & 6.8 & 9.3 & 14.1 & 13.0 & 25.4 & 28.0 & 6.8 & 0.089 & 3.5 & -- & - & 0.089 & 0.00034 \\
\hline \multicolumn{19}{|c|}{21 July 1999 (56 days; $\left.I_{30}=18.75 \mathrm{~mm} / \mathrm{h} ; P=53.6 \mathrm{~mm}\right)$} \\
\hline 1 & 1.3 & -- & -- & 1.6 & 0.7 & 3.3 & 5.5 & 10.4 & 15.2 & 27.4 & 34.6 & 0.0 & 0.024 & 5.8 & 3.0 & 5.0 & 0.024 & 0.00043 \\
\hline 2 & 1.5 & -- & - & 0.9 & 1.8 & 3.6 & 7.3 & 18.5 & 33.4 & 16.3 & 16.7 & 0.0 & 0.034 & 3.0 & 3.8 & 5.0 & 0.034 & 0.00061 \\
\hline 3 & 1.2 & -- & -- & 2.6 & 1.3 & 5.2 & 7.7 & 14.0 & 26.7 & 36.9 & 4.4 & 0.0 & 0.052 & 3.3 & 6.9 & 5.0 & 0.052 & 0.00093 \\
\hline 4 & 0.3 & - & - & 0.3 & 0.8 & 1.8 & 4.0 & 9.6 & 24.2 & 37.6 & 16.4 & 5.2 & 0.179 & 5.0 & 5.1 & 5.0 & 0.18 & 0.0032 \\
\hline Mean & 1.1 & - & -- & 1.4 & 1.2 & 3.5 & 6.1 & 13.1 & 24.9 & 29.6 & 18.0 & 1.3 & 0.072 & 4.3 & 4.7 & -- & 0.072 & 0.0013 \\
\hline $\pm 95 \%$ & 0.9 & - & -- & 1.7 & 0.8 & 2.5 & 2.7 & 6.4 & 13.1 & 15.4 & 21.7 & 3.7 & 0.112 & 2.0 & 2.8 & -- & 0.11 & 0.0020 \\
\hline
\end{tabular}


Table 4.1. (Continued) Summary of particle-size distribution and the flux of sediment into north-facing hillslope traps in a severely burned area of the Spring Creek watershed, 1997-2000

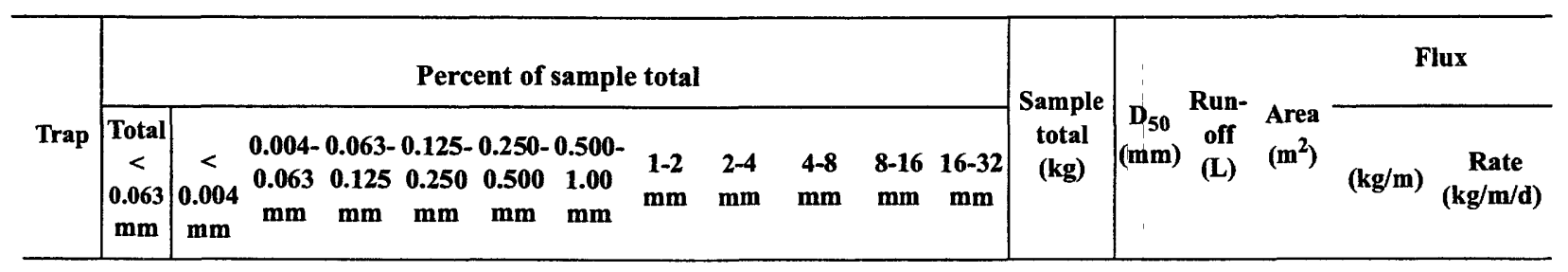

3 November 1999 (105 days; rain gage was not maintained during part of collection interval)

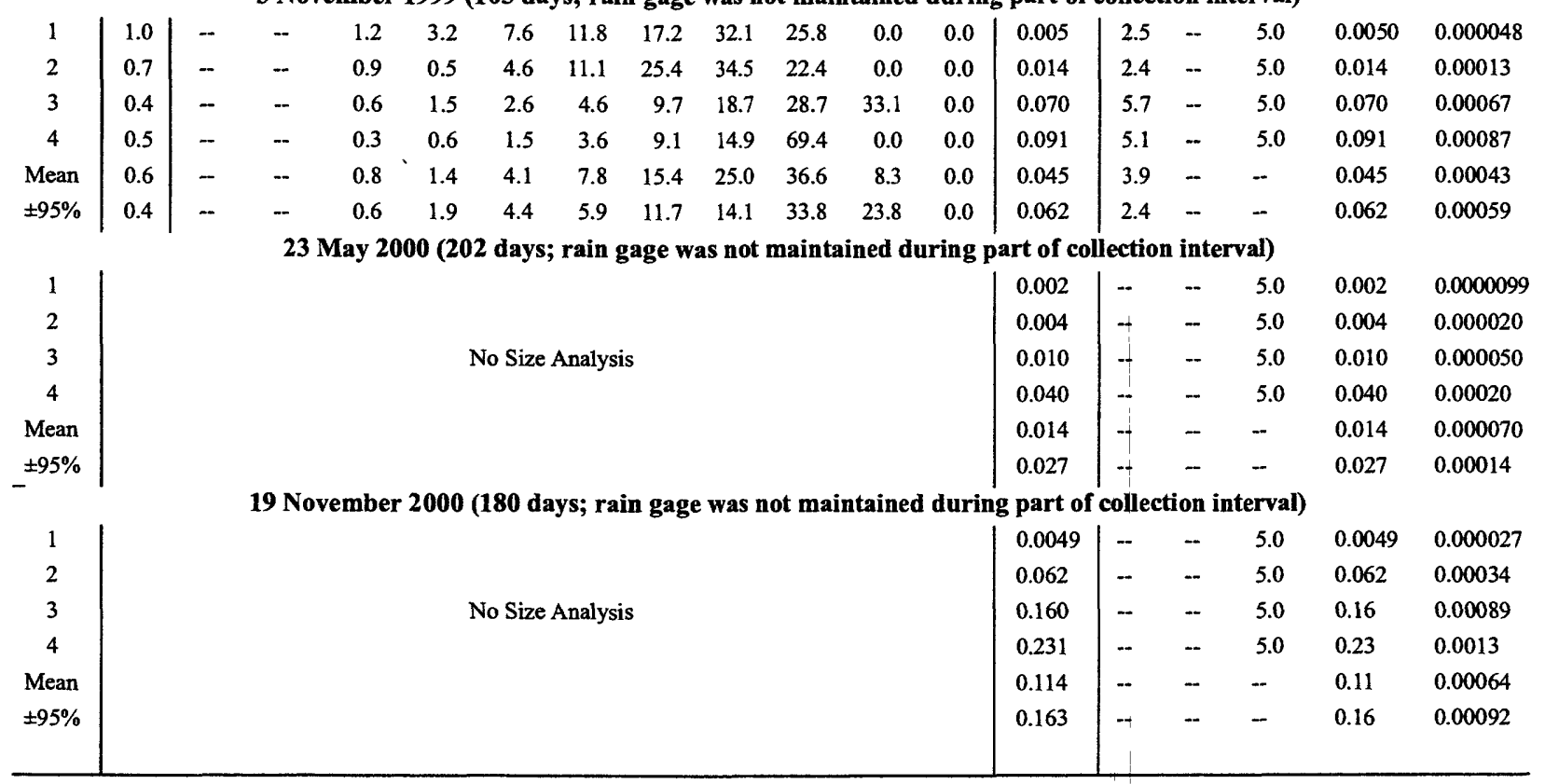

${ }^{a} 0.3$ percent was in the greater than $32 \mathrm{~mm}$ size class.

${ }^{b} \mathrm{~A}$ rain gage malfunctioned during the collection interval and this is the maximum $\mathrm{I}_{30}$ for the available data.

cNo runoff volumes were collected because this was the start of the rainfall sampling season and only the sediment from the winter season was collected. 
Table 4.2. Summary of particle-size distribution and the flux of sediment into south-facing hillslope traps in a severely burned area of the Spring Creek watershed, 1997-2000

[mm, millimeter; $\mathrm{kg}$, kilogram; $\mathrm{L}$, liter; $\mathrm{m}^{2}$, square meter; $\mathrm{kg} / \mathrm{m}$, kilogram per meter; $\mathrm{kg} / \mathrm{m} / \mathrm{d}$, kilogram per meter per day; days in parenthesis are the number of days between collection dates; $\mathrm{mm} / \mathrm{h}$, millimeter per hour; of, overflow; , approximate; $\mathrm{I}_{30}$, maximum 30-minute rainfall intensity; $\mathrm{P}$, total rainfall; $\mathrm{I}_{30}$ and $\mathrm{P}$ calculated from data listed in U.S. Geological Survey 1997, 1998, 1999, and 2000; $\pm 95 \%$, 95-percent confidence limits; in 1997 the effective trap widths for traps $5,6,7$, and 8 , were $1.81,2.35,2.51$, and $2.40 \mathrm{~m}$, and in $1998-2000$ the trap width was $1.00 \mathrm{~m}$ for all traps]

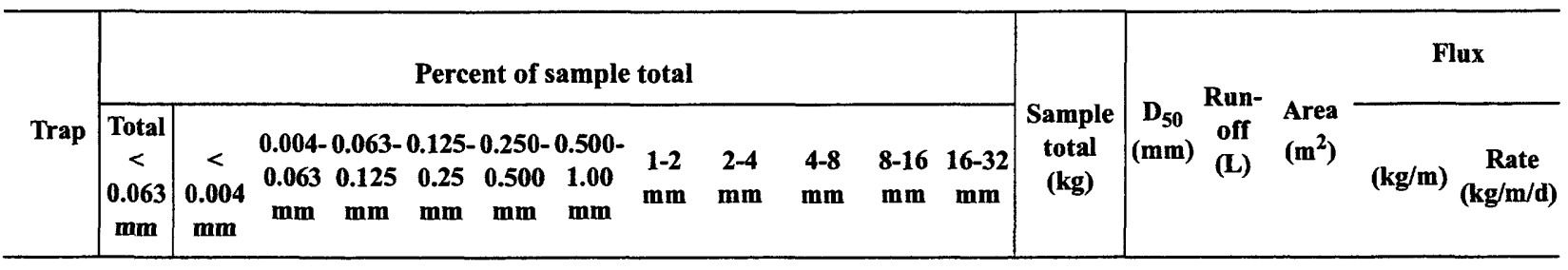

29 July 1997 (8 days; includes the storm on 29 July $1997 ; I_{30}=13.75 \mathrm{~mm} / \mathrm{h} ; P=24.4 \mathrm{~mm}$ )

\begin{tabular}{|c|c|c|c|c|c|c|c|c|c|c|c|c|c|c|c|c|c|c|}
\hline 5 & & 7 & & & & & & & & & 110 & 4 & 151 & 46 & 105 & 100 & 193 & 10 \\
\hline 6 & 11.9 & - & - & 16 & . & 93 & & & 32 & 77 & 0 & & 013 & 0.79 & 29 & 8.02 & .0055 & 00069 \\
\hline 7 & 8.8 & 3.2 & 5.6 & 1.0 & 1.3 & 1.8 & 2.9 & 7.8 & 24.8 & 43.8 & 7.8 & 0.0 & 0.140 & 4.1 & 8.4 & 9.29 & 0.056 & 0.0070 \\
\hline 8 & 16.9 & 4.7 & 12.2 & 3.7 & 2.5 & 5.0 & 8.1 & 14.1 & 23.7 & 19.9 & 6.0 & 0.0 & 0.048 & 2.0 & 5.2 & 13.22 & 0.020 & 0.0025 \\
\hline Mean & 11.5 & 3.6 & 7.8 & 2.1 & 2.4 & 4.6 & 13.4 & 8.2 & 22.7 & 27.0 & 7.2 & 1.0 & 0.088 & 2.9 & 9.0 & - & 0.041 & 0.0051 \\
\hline $\pm 95 \%$ & 6.1 & 2.6 & 8.6 & 1.9 & 2.4 & 5.4 & 25.8 & 7.9 & 4.2 & 26.0 & 10.7 & 3.0 & 0.099 & 2.7 & 12.0 & -- & 0.056 & 0.0070 \\
\hline \multicolumn{19}{|c|}{8 August $1997\left(10\right.$ days; $\left.I_{30}=24.00 \mathrm{~mm} / \mathrm{h} ; P=41.1 \mathrm{~mm}\right)$} \\
\hline 5 & 10.6 & 5.0 & 5.6 & 3.1 & 2.1 & 3.7 & 6.0 & 11.6 & 23.2 & 33.5 & 6.4 & 0.0 & 0.090 & 3.1 & 13.2 & 4.89 & 0.050 & 0.0050 \\
\hline 6 & 15.5 & - & -- & 3.4 & 6.0 & 12.9 & 23.3 & 24.1 & 11.2 & 3.4 & 0.0 & 0.0 & 0.012 & 0.76 & 5.2 & 8.02 & 0.0051 & 0.00051 \\
\hline 7 & 9.4 & 3.3 & 6.1 & 1.0 & 1.3 & 1.8 & 2.6 & 5.0 & 13.0 & 40.0 & 26.1 & 0.0 & 0.125 & 5.6 & 7.8 & 9.29 & 0.050 & 0.0050 \\
\hline 8 & 22.8 & 7.0 & 15.8 & 2.7 & 5.0 & 7.3 & 10.8 & 14.3 & 16.2 & 15.4 & 5.4 & 0.0 & 0.026 & 1.1 & 5.5 & 13.22 & 0.011 & 0.0011 \\
\hline Mean & 14.6 & 5.1 & 9.2 & 2.6 & 3.6 & 6.4 & 10.7 & 13.8 & 15.9 & 23.1 & 9.5 & 0.0 & 0.063 & 2.6 & 7.9 & - & 0.029 & 0.0029 \\
\hline $\pm 95 \%$ & 9.6 & 4.8 & 13.3 & 1.7 & 3.4 & 8.0 & 14.9 & 13.8 & 8.6 & 26.4 & 18.8 & 0.0 & 0.081 & 3.5 & 5.8 & - & 0.032 & 0.0032 \\
\hline \multicolumn{19}{|c|}{14 August $1997\left(6\right.$ days; $\left.I_{30}=9.75 \mathrm{~mm} / \mathrm{h} ; P=18.8 \mathrm{~mm}\right)$} \\
\hline 5 & 3.5 & -- & -. & 0.5 & 0.8 & 1.3 & 1.8 & 3.4 & 9.2 & 24.3 & 10.0 & 45.1 & 0.100 & 12.2 & 10.8 & 4.89 & 0.055 & 0.0092 \\
\hline 6 & 3.7 & - & - & 1.2 & 1.2 & 3.7 & 8.6 & 18.5 & 18.5 & 32.1 & 12.4 & 0.0 & 0.008 & 3.4 & 2.1 & 8.02 & 0.0034 & 0.00057 \\
\hline 7 & 1.8 & -- & -- & 0.3 & 0.3 & 1.0 & 2.1 & 4.2 & 11.7 & 44.7 & 34.0 & 0.0 & 0.038 & 6.6 & 2.0 & 9.29 & 0.015 & 0.0025 \\
\hline 8 & 9.5 & $\rightarrow$ & -- & 1.4 & 1.4 & 2.7 & 4.5 & 8.6 & 19.8 & 28.8 & 23.4 & 0.0 & 0.022 & 4.3 & 3.8 & 13.22 & 0.0092 & 0.0015 \\
\hline Mean & 4.6 & - & - & 0.8 & 0.9 & 2.2 & 4.2 & 8.7 & 14.8 & 32.5 & 20.0 & 11.3 & 0.042 & 6.6 & 4.7 & - & 0.021 & 0.0034 \\
\hline $\pm 95 \%$ & 5.5 & - & - & 0.8 & 0.8 & 1.9 & 4.9 & 10.9 & 7.6 & 14.7 & 17.3 & 32.5 & 0.066 & 6.3 & 6.3 & - & 0.037 & 0.0062 \\
\hline \multicolumn{19}{|c|}{18 August $1997\left(4\right.$ days; $\left.I_{30}=3.00 \mathrm{~mm} / \mathrm{h} ; P=4.8 \mathrm{~mm}\right)$} \\
\hline 5 & 3.5 & - & - & 0.9 & 0.9 & 1.8 & 3.5 & 8.8 & 16.8 & 45.6 & 18.1 & 0.0 & 0.023 & 5.2 & 2.4 & 4.89 & 0.013 & 0.0032 \\
\hline 6 & 4.2 & - & - & 3.8 & 3.8 & 7.7 & 19.2 & 26.9 & 19.2 & 15.4 & 0.0 & 0.0 & 0.003 & 1.4 & 0.6 & 8.02 & 0.0013 & 0.00032 \\
\hline 7 & 1.5 & - & -. & 0.8 & 0.8 & 1.5 & 3.0 & 5.3 & 12.0 & 26.3 & 48.9 & 0.0 & 0.013 & 7.8 & 0.5 & 9.29 & 0.0052 & 0.0013 \\
\hline 8 & 2.5 & - & -- & 2.1 & 2.1 & 4.2 & 8.3 & 18.7 & 14.5 & 47.7 & 0.0 & 0.0 & 0.005 & 3.6 & 0.6 & 13.22 & 0.0021 & 0.00052 \\
\hline Mean & 2.9 & - & - & 1.9 & 1.9 & 3.8 & 8.5 & 14.9 & 15.6 & 33.8 & 16.8 & 0.0 & 0.011 & 4.5 & 1.0 & - & 0.0054 & 0.0013 \\
\hline $\pm 95 \%$ & 1.9 & - & - & 2.2 & 2.2 & 4.5 & 11.7 & 15.6 & 5.2 & 23.3 & 35.2 & 0.0 & 0.014 & 4.6 & 1.4 & - & 0.0084 & 0.0021 \\
\hline \multicolumn{19}{|c|}{20 August $1997\left(2\right.$ days; $\left.I_{30}=5.00 \mathrm{~mm} / \mathrm{h} ; P=2.8 \mathrm{~mm}\right)$} \\
\hline 5 & 4.6 & - & -- & 1.6 & 0.8 & 2.3 & 3.1 & 6.2 & 15.5 & 39.5 & 26.4 & 0.0 & 0.013 & 5.6 & 1.4 & 4.89 & 0.0072 & 0.0036 \\
\hline 6 & 8.3 & -. & -- & 8.3 & 8.3 & 12.5 & 25.0 & 25.0 & 12.5 & 0.0 & 0.0 & 0.0 & 0.001 & 0.75 & 0.3 & 8.02 & 0.00043 & 0.00021 \\
\hline 7 & 1.7 & - & -. & 3.2 & 1.7 & 3.2 & 6.4 & 6.4 & 35.5 & 41.9 & 0.0 & 0.0 & 0.003 & 3.5 & 0.2 & 9.29 & 0.0012 & 0.00060 \\
\hline 8 & 6.2 & -- & -- & 6.2 & 12.5 & 12.5 & 12.5 & 31.2 & 18.8 & 0.0 & 0.0 & 0.0 & 0.002 & 1.0 & 0.3 & 13.22 & 0.00083 & 0.00042 \\
\hline Mean & 5.2 & - & - & 4.8 & 5.8 & 7.6 & 11.8 & 17.2 & 20.6 & 20.4 & 6.6 & 0.0 & 0.005 & 2.7 & 0.6 & - & 0.0024 & 0.0012 \\
\hline $\pm 95 \%$ & 4.8 & -- & - & 4.8 & 8.4 & 7.3 & 15.8 & 18.0 & 16.6 & 30.2 & 19.0 & 0.0 & 0.009 & 3.5 & 0.9 & -- & 0.0049 & 0.0024 \\
\hline
\end{tabular}


Table 4.2. (Continued) Summary of particle-size distribution and the flux of sediment into south-facing hillslope traps in a severely burned area of the Spring Creek watershed, 1997-2000

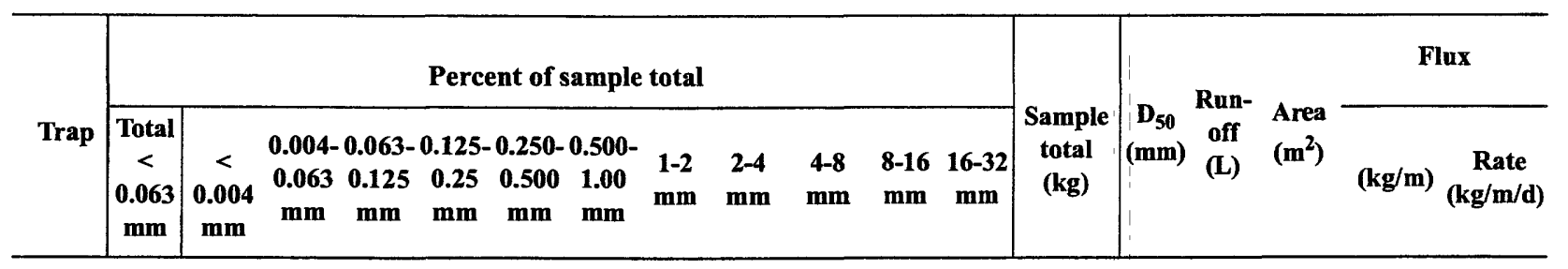

31 August 1997 (11 days; $\mathbf{I}_{30}=11.25 \mathrm{~mm} / \mathrm{h} ; P=13.7 \mathrm{~mm}$ )

\begin{tabular}{|c|c|c|c|c|c|c|c|c|c|c|c|c|c|c|c|c|c|c|}
\hline 5 & 5.8 & -- & - & 1.2 & 1.9 & 2.9 & 4.2 & 8.7 & 20.5 & 42.7 & 12.2 & 0.0 & 0.052 & 4.4 & 6.1 & 4.89 & 0.029 & 0.0026 \\
\hline 6 & 11.9 & - & -- & 4.5 & 1.5 & 7.5 & 14.9 & 20.9 & 16.4 & 22.4 & 0.0 & 0.0 & 0.007 & 1.5 & 1.7 & 8.02 & 0.0030 & 0.00027 \\
\hline 7 & 8.0 & -- & -- & 0.9 & 1.8 & 2.2 & 4.5 & 8.0 & 21.9 & 41.5 & 11.2 & 0.0 & 0.022 & 4.3 & 2.2 & 9.29 & 0.0088 & 0.00080 \\
\hline 8 & 17.4 & -- & -. & 2.9 & 2.0 & 3.1 & 3.4 & 7.4 & 11.1 & 10.0 & 5.1 & 37.4 & 0.035 & 5.1 & 6.4 & 13.22 & 0.015 & 0.0013 \\
\hline Mean & 10.8 & - & - & 2.4 & 1.8 & 3.9 & 6.8 & 11.2 & 17.5 & 29.2 & 7.1 & 9.4 & 0.029 & 3.8 & 4.1 & -- & 0.014 & 0.0012 \\
\hline $\pm 95 \%$ & 8.4 & - & - & 2.6 & 0.4 & 3.8 & 8.3 & 9.7 & 7.8 & 23.5 & 8.8 & 26.9 & 0.032 & 2.6 & 3.4 & -- & 0.019 & 0.0017 \\
\hline
\end{tabular}

4 September 1997 (traps overflowed; totals are minimum estimates; duration was rounded to $1 \mathrm{day} ; \mathrm{I}_{30}=88.00 \mathrm{~mm} / \mathrm{h} ; \mathrm{P}=51.3 \mathrm{~mm}$ )

\begin{tabular}{|c|c|c|c|c|c|c|c|c|c|c|c|c|c|c|c|c|c|c|}
\hline 5 & 0.3 & -- & -. & 0.5 & 0.6 & 1.0 & 1.5 & 2.9 & 10.8 & 34.5 & 42.6 & 5.3 & 0.272 & 7.8 & of & 4.89 & 0.15 & 0.15 \\
\hline 6 & 0.4 & - & - & 0.4 & 0.4 & 0.6 & 1.0 & 2.5 & 6.8 & 36.4 & 51.6 & 0.0 & 0.254 & 8.2 & of & 8.02 & 0.11 & 0.11 \\
\hline 7 & 3.5 & -- & - & 2.8 & 2.3 & 2.4 & 3.2 & 7.5 & 21.1 & 34.0 & 21.5 & 1.7 & 1.820 & 4.8 & of & 9.29 & 0.73 & 0.73 \\
\hline 8 & 2.4 & - & -- & 1.5 & 1.7 & 2.7 & 4.8 & 11.2 & 25.7 & 36.6 & 12.6 & 0.8 & 3.403 & 4.0 & of & 13.22 & 1.42 & 1.42 \\
\hline Mean & 1.6 & - & - & 1.3 & 1.2 & 1.7 & 2.6 & 6.0 & 16.1 & 35.4 & 32.1 & 2.0 & 1.437 & 6.2 & -- & -- & 0.60 & 0.60 \\
\hline $\pm 95 \%$ & 2.3 & - & - & 1.7 & 1.4 & 1.5 & 2.7 & 6.3 & 13.6 & 1.9 & 28.1 & 3.8 & 2.267 & 3.0 & -- & -- & 0.94 & 0.94 \\
\hline \multicolumn{19}{|c|}{15 September $1997\left(11\right.$ days; $\left.I_{30}=13.75 \mathrm{~mm} / \mathrm{h} ; P=8.4 \mathrm{~mm}\right)$} \\
\hline 5 & 0.8 & - & - & 1.2 & 1.0 & 2.3 & 3.4 & 5.4 & 13.1 & 30.5 & 32.6 & 9.7 & 0.128 & 7.0 & 4.0 & 4.89 & 0.071 & 0.0064 \\
\hline 6 & 1.2 & -- & - & 0.4 & 0.8 & 1.9 & 5.8 & 12.4 & 18.2 & 32.6 & 26.7 & 0.0 & 0.026 & 5.1 & 1.0 & 8.02 & 0.011 & 0.0010 \\
\hline 7 & 7.4 & -- & -- & 0.7 & 0.6 & 5.8 & 9.3 & 18.1 & 24.2 & 24.3 & 9.6 & 0.0 & 0.166 & 2.7 & 4.0 & 9.29 & 0.066 & 0.0060 \\
\hline 8 & 4.1 & 0.3 & 3.8 & 2.7 & 2.5 & 4.9 & 6.9 & 12.2 & 23.9 & 33.3 & 9.6 & 0.0 & 0.101 & 3.4 & 4.0 & 13.22 & 0.042 & 0.0038 \\
\hline Mean & 3.4 & -- & -- & 1.2 & 1.2 & 3.7 & 6.4 & 12.0 & 19.8 & 30.2 & 19.6 & 2.4 & 0.105 & 4.6 & 3.2 & - & 0.048 & 0.0043 \\
\hline $\pm 95 \%$ & 4.8 & .. & - & 1.7 & 1.4 & 2.8 & 4.2 & 9.1 & 8.0 & 6.5 & 16.6 & 7.0 & 0.101 & 3.1 & 2.2 & -- & 0.043 & 0.0040 \\
\hline \multicolumn{19}{|c|}{2 October $1997\left(17\right.$ days; $\left.I_{30}=5.00 \mathrm{~mm} / \mathrm{h} ; P=7.9 \mathrm{~mm}\right)$} \\
\hline 5 & 2.1 & -- & - & 0.2 & 0.3 & 0.6 & 1.4 & 2.4 & 5.7 & 25.2 & 36.6 & 25.5 & 0.066 & 10.6 & 3.9 & 4.89 & 0.036 & 0.0021 \\
\hline 6 & 14.4 & -- & - & 1.5 & 0.0 & 1.5 & 1.5 & 3.1 & 1.5 & 9.2 & 67.3 & 0.0 & 0.007 & 10.0 & 0.8 & 8.02 & 0.0026 & 0.00015 \\
\hline 7 & 0.4 & -- & - & 0.9 & 0.2 & 1.8 & 2.9 & 7.0 & 17.2 & 26.9 & 13.2 & 29.5 & 0.079 & 6.9 & $\sim 1.6$ & 9.29 & 0.031 & 0.0018 \\
\hline 8 & 8.0 & -- & -- & 0.0 & 2.0 & 6.0 & 8.0 & 14.0 & 36.0 & 26.0 & 0.0 & 0.0 & 0.005 & 2.7 & $\sim 1.4$ & 13.22 & 0.0021 & 0.00012 \\
\hline Mean & 6.2 & - & - & 0.6 & 0.6 & 2.5 & 3.4 & 6.6 & 15.1 & 21.8 & 29.3 & 13.8 & 0.039 & 7.6 & $\sim 2$ & - & 0.018 & 0.0010 \\
\hline $\pm 95 \%$ & 10.1 & - & - & 1.1 & 1.4 & 3.9 & 4.8 & 8.4 & 24.8 & 12.7 & 48.5 & 21.2 & 0.053 & 5.7 & $\sim 2$ & - & 0.024 & 0.0014 \\
\hline \multicolumn{19}{|c|}{16 June $1998\left(11\right.$ days; $\left.I_{30}=13.75 \mathrm{~mm} / \mathrm{h} ; P=14.7 \mathrm{~mm}\right)$} \\
\hline 5 & 0.1 & - & - & 0.2 & 0.6 & 1.2 & 2.3 & 2.6 & 5.8 & 87.3 & 0.0 & 0.0 & 0.050 & 5.7 & 1.7 & 5.0 & 0.050 & 0.0045 \\
\hline 6 & 1.1 & - & - & 2.8 & 4.4 & 11.1 & 15.8 & 11.4 & 10.0 & 43.3 & 0.0 & 0.0 & 0.004 & 2.7 & 1.4 & 5.0 & 0.0040 & 0.00036 \\
\hline 7 & 0.2 & - & - & 0.7 & 1.4 & 2.9 & 5.3 & 12.7 & 29.3 & 47.5 & 0.0 & 0.0 & 0.022 & 3.8 & 1.4 & 5.0 & 0.022 & 0.0020 \\
\hline 8 & 1.3 & - & - & 2.0 & 3.6 & 6.5 & 10.4 & 12.2 & 18.6 & 45.3 & 0.0 & 0.0 & 0.008 & 3.5 & 1.4 & 5.0 & 0.0080 & 0.00073 \\
\hline Mean & 0.7 & - & - & 1.4 & 2.5 & 5.4 & 8.4 & 9.7 & 15.9 & 55.8 & 0.0 & 0.0 & 0.021 & 3.9 & 1.5 & - & 0.021 & 0.0019 \\
\hline $\pm 95 \%$ & 0.9 & - & - & 1.9 & 2.7 & 7.1 & 9.7 & 7.3 & 16.9 & 31.7 & 0.0 & 0.0 & 0.033 & 2.2 & 0.2 & -. & 0.033 & 0.0030 \\
\hline
\end{tabular}


Table 4.2. (Continued) Summary of particle-size distribution and the flux of sediment into south-facing hillslope traps in a severely burned area of the Spring Creek watershed, 1997-2000

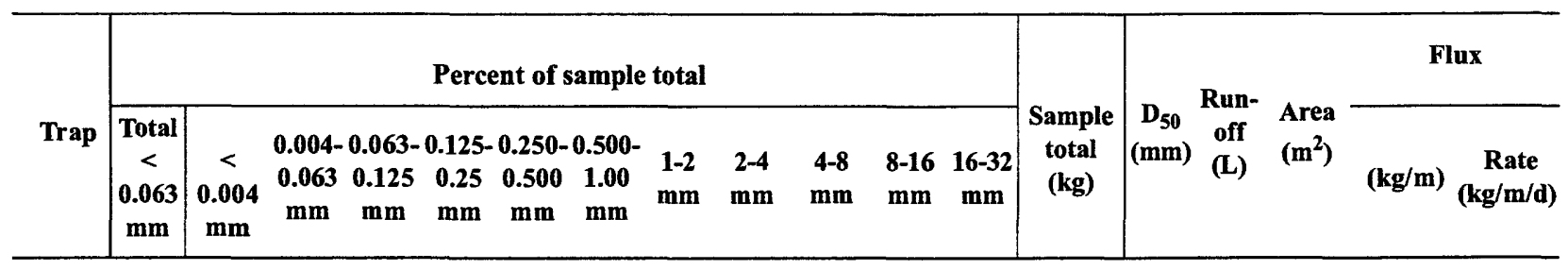

\begin{tabular}{|c|c|c|c|c|c|c|c|c|c|c|c|c|c|c|c|c|c|c|}
\hline \multicolumn{19}{|c|}{11 July 1998 ( 25 days; $\left.I_{30}=7.50 \mathrm{~mm} / \mathrm{h}^{2} ; P=21.1 \mathrm{~mm}\right)$} \\
\hline 5 & 1.5 & - & - & 2.0 & 5.1 & 10.2 & 10.2 & 10.2 & 20.3 & 40.6 & 0.0 & 0.0 & 0.002 & 3.1 & 1.4 & 5.0 & 0.0020 & 0.000080 \\
\hline 6 & 2.6 & - & - & 1.9 & 6.4 & 6.4 & 6.4 & 6.4 & 0.0 & 70.1 & 0.0 & 0.0 & 0.002 & 5.1 & 2.0 & 5.0 & 0.0020 & 0.000080 \\
\hline 7 & 0.9 & -. & - & 0.9 & 1.9 & 3.7 & 10.3 & 7.5 & 15.9 & 48.6 & 10.3 & 0.0 & 0.011 & 4.7 & 2.1 & 5.0 & 0.011 & 0.00044 \\
\hline 8 & 0.0 & .. & - & 1.0 & 3.2 & 9.6 & 12.8 & 9.6 & 25.6 & 38.3 & 0.0 & 0.0 & 0.003 & 3.1 & 2.1 & 5.0 & 0.0030 & 0.00012 \\
\hline Mean & 1.2 & -- & -- & 1.4 & 4.2 & 7.5 & 9.9 & 8.4 & 15.4 & 49.4 & 2.6 & 0.0 & 0.004 & 4.0 & 1.9 & - & 0.0045 & 0.00018 \\
\hline $\pm 95 \%$ & 1.9 & - & - & 0.8 & 3.2 & 4.7 & 4.6 & 2.7 & 18.4 & 22.9 & 7.4 & 0.0 & 0.006 & 1.5 & 0.5 & -- & 0.0065 & 0.00026 \\
\hline \multicolumn{19}{|c|}{4 August $1998\left(24\right.$ days; $\left.I_{30}=28.50 \mathrm{~mm} / \mathrm{h} P=69.1 \mathrm{~mm}\right)$} \\
\hline 5 & 0.1 & - & -- & 0.1 & 0.3 & 1.0 & 1.7 & 2.6 & 6.4 & 32.7 & 31.7 & 23.4 & 0.070 & 9.3 & 3.9 & 5.0 & 0.070 & 0.0029 \\
\hline 6 & 0.1 & - & .. & 0.2 & 1.4 & 2.8 & 3.5 & 4.2 & 6.3 & 25.1 & 56.5 & 0.0 & 0.014 & 8.9 & 6.3 & 5.0 & 0.014 & 0.00058 \\
\hline 7 & 0.4 & -- & - & 0.5 & 0.5 & 1.4 & 3.0 & 8.3 & 20.4 & 28.3 & 13.3 & 23.9 & 0.080 & 6.2 & 6.5 & 5.0 & 0.080 & 0.0033 \\
\hline 8 & 0.9 & - & -- & 0.9 & 2.7 & 5.0 & 6.8 & 8.6 & 17.3 & 32.3 & 25.4 & 0.0 & 0.022 & 5.0 & 6.5 & 5.0 & 0.022 & 0.00092 \\
\hline Mean & 0.4 & - & -- & 0.4 & 1.2 & 2.6 & 3.8 & 5.9 & 12.6 & 29.6 & 31.7 & 11.8 & 0.046 & 7.4 & 5.8 & - & 0.046 & 0.0019 \\
\hline $\pm 95 \%$ & 0.6 & - & - & 0.6 & 1.7 & 2.9 & 3.7 & 4.3 & 10.2 & 5.2 & 31.1 & 17.2 & 0.048 & 3.1 & 1.9 & - & 0.048 & 0.0020 \\
\hline \multicolumn{19}{|c|}{9 September $1998\left(36\right.$ days; $\left.I_{30}=14.75 \mathrm{~mm} / \mathrm{h} ; P=36.1 \mathrm{~mm}\right)$} \\
\hline 5 & 0.4 & - & - & 0.0 & 0.2 & 0.9 & 1.6 & 1.9 & 4.7 & 27.4 & 29.0 & 33.9 & 0.054 & 11.6 & 4.0 & 5.0 & 0.054 & 0.0015 \\
\hline 6 & 0.0 & .. & - & 0.3 & 0.8 & 1.8 & 2.7 & 3.1 & 4.3 & 8.8 & 78.1 & 0.0 & 0.010 & 10.9 & 2.4 & 5.0 & 0.010 & 0.00028 \\
\hline 7 & 0.2 & -. & - & 0.5 & 0.4 & 1.1 & 2.0 & 4.8 & 14.9 & 27.0 & 30.0 & 19.2 & 0.074 & 7.9 & 3.2 & 5.0 & 0.074 & 0.0021 \\
\hline 8 & 1.0 & -- & - & 1.5 & 3.0 & 4.8 & 5.6 & 9.7 & 15.6 & 39.1 & 19.7 & 0.0 & 0.010 & 4.9 & 2.0 & 5.0 & 0.010 & 0.00028 \\
\hline Mean & 0.4 & -- & - & 0.6 & 1.1 & 2.2 & 3.0 & 4.9 & 9.9 & 25.6 & 39.2 & 13.3 & 0.037 & 8.8 & 2.9 & - & 0.037 & 0.0010 \\
\hline $\pm 95 \%$ & 0.7 & -- & -- & 1.6 & 2.0 & 2.8 & 2.9 & 5.6 & 8.1 & 21.8 & 42.0 & 24.4 & 0.046 & 4.8 & 1.4 & - & 0.046 & 0.0013 \\
\hline \multicolumn{19}{|c|}{16 November 1998 (68 days; rain gage was not maintained during part of collection interval) } \\
\hline 5 & 0.2 & -- & - & 0.2 & 0.2 & 0.9 & 1.4 & 2.9 & 3.2 & 26.8 & 64.2 & 0.0 & 0.018 & 9.8 & 1.8 & 5.0 & 0.018 & 0.00026 \\
\hline 6 & 1.7 & - & - & 0.3 & 1.0 & 1.5 & 1.1 & 2.2 & 2.8 & 4.8 & 84.6 & 0.0 & 0.007 & 11.3 & 3.2 & 5.0 & 0.0070 & 0.00010 \\
\hline 7 & 0.2 & -. & -- & 0.1 & 0.2 & 0.6 & 1.8 & 6.2 & 24.2 & 12.2 & 54.4 & 0.0 & 0.013 & 8.7 & 3.7 & 5.0 & 0.013 & 0.00019 \\
\hline 8 & 0.0 & -- & -- & 0.2 & 0.0 & 0.3 & 0.3 & 1.4 & 3.2 & 9.4 & 85.2 & 0.0 & 0.007 & 11.3 & 3.0 & 5.0 & 0.0070 & 0.00010 \\
\hline Mean & 0.5 & -. & - & 0.2 & 0.4 & 0.8 & 1.2 & 3.2 & 8.4 & 13.3 & 72.1 & 0.0 & 0.011 & 10.3 & 2.9 & -- & 0.011 & 0.00016 \\
\hline $\pm 95 \%$ & 1.2 & - & -- & 0.1 & 0.7 & 0.9 & 1.1 & 3.5 & 15.4 & 15.8 & 22.2 & 0.0 & 0.008 & 1.9 & 1.4 & - & 0.0080 & 0.00012 \\
\hline \multicolumn{19}{|c|}{5 May 1999 (170 days; rain gage was not maintained during part of collection interval) } \\
\hline 5 & 0.1 & - & - & 0.1 & 0.1 & 0.2 & 0.3 & 0.6 & 0.9 & 3.9 & 41.0 & 52.8 & 0.136 & 16.8 & 12.9 & 5.0 & 0.14 & 0.00080 \\
\hline 6 & 0.4 & - & -- & 0.5 & 0.3 & 1.2 & 1.6 & 2.5 & 4.3 & 22.7 & 66.4 & 0.0 & 0.036 & 10.0 & 22.3 & 5.0 & 0.036 & 0.00021 \\
\hline 7 & 0.2 & -. & - & 0.3 & 0.1 & 0.7 & 1.3 & 3.6 & 11.4 & 25.4 & 51.7 & 5.3 & 0.122 & 9.1 & $\sim 24$ & 5.0 & 0.12 & 0.00072 \\
\hline 8 & 0.6 & - & - & 0.2 & 0.6 & 1.2 & 1.8 & 3.0 & 3.7 & 16.6 & 42.2 & 30.0 & 0.021 & 12.2 & 4.0 & 5.0 & 0.021 & 0.00012 \\
\hline Mean & 0.3 & - & -- & 0.3 & 0.3 & 0.8 & 1.2 & 2.4 & 5.1 & 17.2 & 50.3 & 22.0 & 0.079 & 12.0 & 15.8 & -- & 0.079 & 0.00046 \\
\hline $\pm 95 \%$ & 0.4 & - & - & 0.3 & 0.4 & 0.7 & 1.1 & 2.2 & 7.6 & 15.5 & 18.3 & 38.0 & 0.083 & 5.5 & 14.4 & - & 0.086 & 0.00049 \\
\hline
\end{tabular}


Table 4.2. (Continued) Summary of particle-size distribution and the flux of sediment into south-facing hillslope traps in a severely burned area of the Spring Creek watershed, 1997-2000

\begin{tabular}{|c|c|c|c|c|c|c|c|c|c|c|c|c|c|c|c|}
\hline \multirow[b]{2}{*}{ Trap } & \multicolumn{10}{|c|}{ Percent of sample total } & \multirow[b]{2}{*}{$\begin{array}{c}\text { Sample } \\
\text { total } \\
(\mathrm{kg})\end{array}$} & \multirow{2}{*}{$\begin{array}{l}\mathbf{D}_{\mathbf{5 0}} \\
(\mathbf{m m})\end{array}$} & \multirow{2}{*}{$\begin{array}{c}\text { Run- } \\
\text { off } \\
\text { (L) }\end{array}$} & \multirow{2}{*}{$\begin{array}{l}\text { Area } \\
\left(\mathrm{m}^{2}\right)\end{array}$} & Flux \\
\hline & $\begin{array}{c}\text { Total } \\
< \\
0.063 \\
\text { mm }\end{array}$ & $\begin{array}{c}< \\
0.004 \\
\mathrm{~mm}\end{array}$ & $\begin{array}{cc}0.004-0.063- \\
0.063 & 0.125 \\
\mathrm{~mm} & \mathrm{~mm}\end{array}$ & $\begin{array}{c}0.125- \\
0.25 \\
\mathrm{~mm}\end{array}$ & $\begin{array}{c}0.250- \\
0.500 \\
\mathrm{~mm}\end{array}$ & $\begin{array}{l}0.500- \\
1.00 \\
\mathrm{~mm}\end{array}$ & $\begin{array}{l}1-2 \\
\mathrm{~mm}\end{array}$ & $\begin{array}{l}2-4 \\
\mathrm{~mm}\end{array}$ & $\begin{array}{l}4-8 \\
\mathrm{~mm}\end{array}$ & $\begin{array}{cc}8-16 & 16-32 \\
\mathrm{~mm} & \mathrm{~mm}\end{array}$ & & & & & $(\mathrm{~kg} / \mathrm{m}) \underset{(\mathrm{kg} / \mathrm{m} / \mathrm{d})}{\stackrel{\text { Rate }}{ }}$ \\
\hline
\end{tabular}

26 May 1999 ( 21 days; $I_{30}=11 \mathrm{~mm} / \mathrm{h} ; P=41.1 \mathrm{~mm}$ )

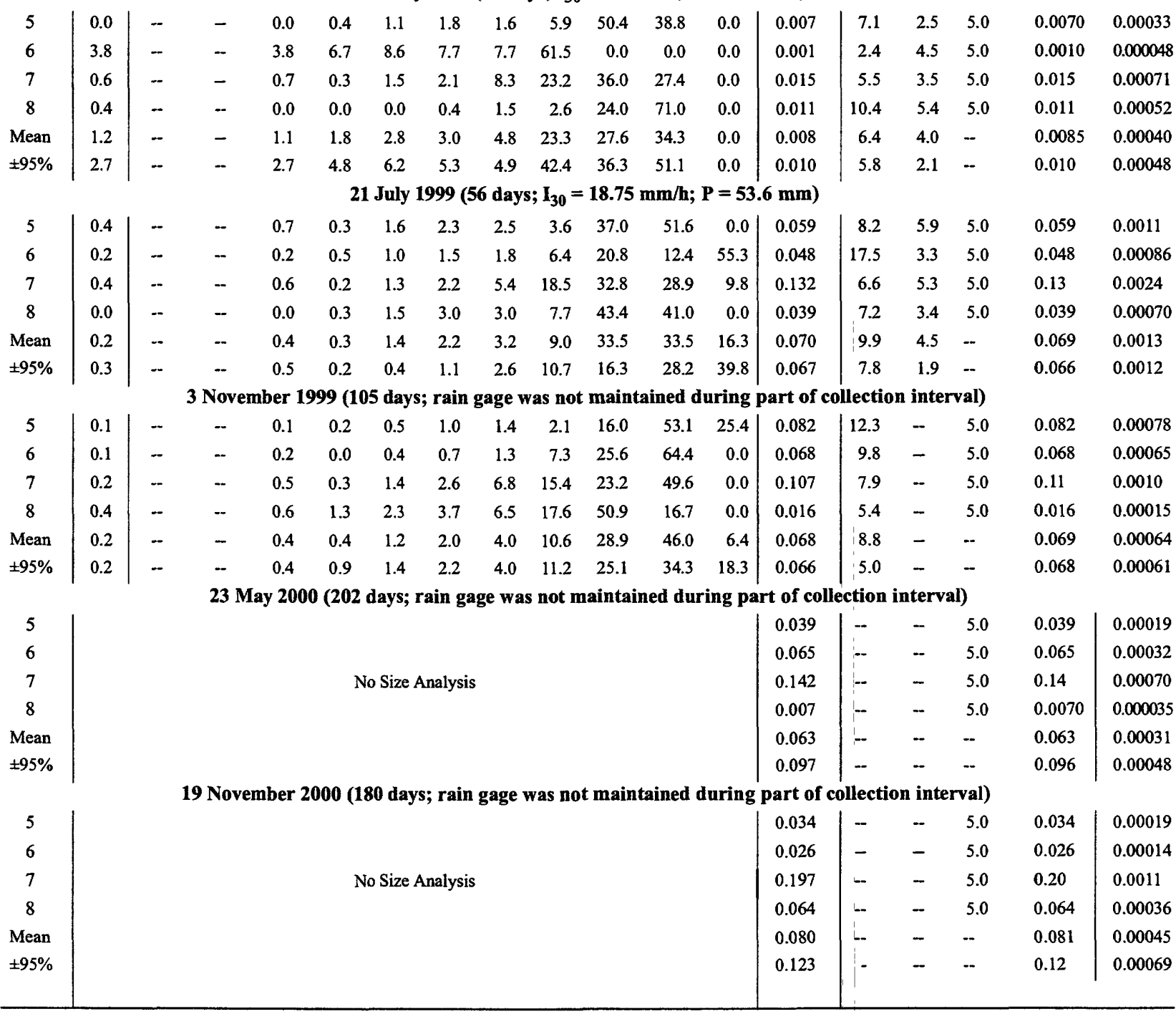

\footnotetext{
${ }^{\mathrm{a}} \mathrm{A}$ rain gage malfunctioned during the collection interval and this is the maximum $\mathrm{I}_{30}$ for the available data
} 
Table 4.3. Summary of particle-size distribution and the flux of sediment into north-facing hillslope traps in an unburned area of the Spring Creek watershed, 1998-2000

[mm, millimeter; $\mathrm{kg}$, kilogram; $\mathrm{L}$, liter; $\mathrm{m}^{2}$, square meter; $\mathrm{kg} / \mathrm{m}$, kilogram per meter; $\mathrm{kg} / \mathrm{m} / \mathrm{d}$, kilogram per meter per day; days in parenthesis are the number of days between collection dates; $\mathrm{mm} / \mathrm{h}$, millimeter per hour; of, overflow; $\sim$, approximate; $\mathrm{I}_{30}$, maximum 30-minute rainfall intensity; $\mathrm{P}$, total rainfall; $\mathrm{I}_{30}$ and $\mathrm{P}$ calculated from data for a rain gage about 1.3 kilometers away from the traps and listed in U.S. Geological Survey 1997, 1998, 1999, and 2000; $\pm 95 \%$, 95-percent confidence limits; na, not available; trap width was $1.00 \mathrm{~m}$ for all traps]

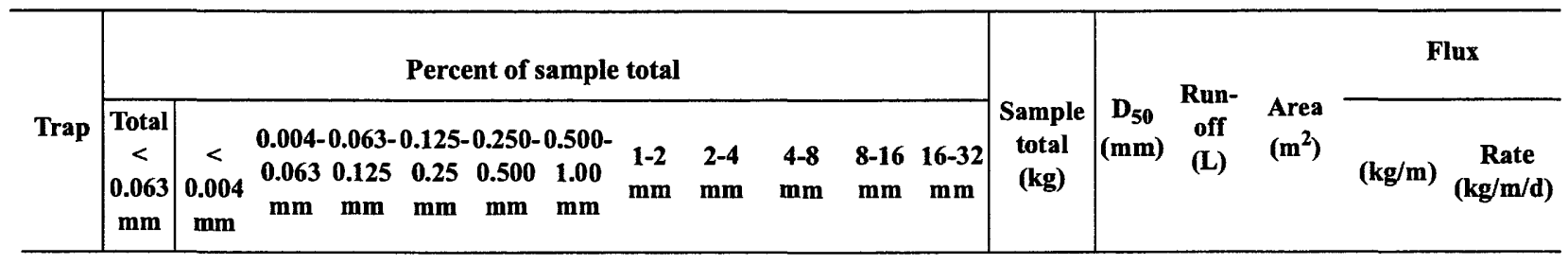

\begin{tabular}{c|r|rrrrrrrrrrr|r|}
9 & 0.3 & - & - & 1.4 & 4.9 & 10.4 & 18.0 & 28.9 & 30.5 & 5.7 & 0.0 & 0.0 & 0.004 \\
10 & 0.3 & - & - & 0.8 & 1.2 & 1.7 & 4.2 & 9.7 & 22.4 & 59.6 & 0.0 & 0.0 & 0.042 \\
11 & 0.2 & - & - & 0.8 & 1.2 & 2.1 & 4.3 & 11.6 & 26.0 & 53.8 & 0.0 & 0.0 & 0.013 \\
12 & 0.8 & - & - & 1.9 & 3.7 & 6.3 & 10.9 & 19.4 & 27.3 & 29.8 & 0.0 & 0.0 & 0.019 \\
Mean & 0.4 & - & - & 1.2 & 2.8 & 5.1 & 9.4 & 17.4 & 26.6 & 37.2 & 0.0 & 0.0 & 0.020 \\
$\pm 95 \%$ & 0.4 & - & - & 0.8 & 2.7 & 6.3 & 9.9 & 13.8 & 5.8 & 38.8 & 0.0 & 0.0 & 0.027
\end{tabular}

\begin{tabular}{|lll}
1.5 & 0.6 & 5.0 \\
4.7 & 1.4 & 5.0 \\
4.3 & 1.1 & 5.0 \\
2.5 & 0.6 & 5.0 \\
3.2 & 0.9 & -- \\
2.3 & 0.6 & --
\end{tabular}

$0.0040 \quad 0.00036$

11 July 1998 ( 25 days; $\left.I_{30}=7.50 \mathrm{~mm} / \mathrm{h}^{\mathbf{a}} ; P=21.1 \mathrm{~mm}\right)$

\begin{tabular}{|c|c|c|c|c|c|c|c|c|c|c|c|c|c|c|c|c|c|c|}
\hline 9 & 3.6 & - & - & 5.1 & 5.1 & 10.2 & 11.7 & 19.7 & 25.6 & 19.0 & 0.0 & 0.0 & 0.014 & 1.7 & 4.0 & 5.0 & 0.014 & 0.00056 \\
\hline 10 & 0.8 & - & -- & 0.8 & 1.9 & 3.4 & 7.3 & 15.7 & 22.2 & 23.8 & 24.1 & 0.0 & 0.026 & 3.8 & 4.7 & 5.0 & 0.026 & 0.0010 \\
\hline 11 & 0.6 & -- & - & 1.9 & 6.9 & 1.9 & 6.2 & 15.6 & 34.4 & 28.1 & 4.4 & 0.0 & 0.016 & 3.0 & 3.6 & 5.0 & 0.016 & 0.00064 \\
\hline 12 & 6.3 & 0.1 & 6.2 & 5.5 & 6.1 & 10.9 & 13.6 & 20.3 & 20.6 & 13.0 & 3.6 & 0.0 & 0.033 & 1.4 & 5.4 & 5.0 & 0.033 & 0.0013 \\
\hline Mean & 2.8 & -- & -- & 3.3 & 5.0 & 6.6 & 9.7 & 17.8 & 25.7 & 21.0 & 8.0 & 0.0 & 0.022 & 2.5 & 4.4 & -- & 0.022 & 0.00088 \\
\hline $\pm 95 \%$ & 4.2 & - & - & 3.4 & 3.6 & 6.5 & 5.3 & 3.4 & 9.9 & 10.9 & 17.4 & 0.0 & 0.014 & 1.7 & 1.3 & -- & 0.014 & 0.00053 \\
\hline \multicolumn{19}{|c|}{4 August $1998\left(24\right.$ days; $\left.I_{30}=28.50 \mathrm{~mm} / \mathrm{h} ; P=69.1 \mathrm{~mm}\right)$} \\
\hline 9 & 1.2 & - & -- & 1.2 & 3.5 & 7.1 & 14.1 & 21.2 & 25.9 & 25.9 & 0.0 & 0.0 & 0.008 & 2.1 & 3.3 & 5.0 & 0.008 & 0.0003 \\
\hline 10 & 0.4 & -- & -- & 0.3 & 0.7 & 1.3 & 2.7 & 8.6 & 19.0 & 26.6 & 40.3 & 0.0 & 0.095 & 6.6 & 6.2 & 5.0 & 0.095 & 0.0040 \\
\hline 11 & 0.5 & - & -- & 0.4 & 0.7 & 2.0 & 4.0 & 11.9 & 36.4 & 44.3 & 0.0 & 0.0 & 0.015 & 3.7 & 2.6 & 5.0 & 0.015 & 0.00062 \\
\hline 12 & 1.5 & -- & - & 2.3 & 2.3 & 5.7 & 10.6 & 22.3 & 30.9 & 21.5 & 3.0 & 0.0 & 0.026 & 2.3 & 3.3 & 5.0 & 0.026 & 0.0011 \\
\hline Mean & 0.9 & -- & - & 1.0 & 1.8 & 4.0 & 7.8 & 16.0 & 28.0 & 29.6 & 10.8 & 0.0 & 0.036 & 3.7 & 3.8 & -- & 0.036 & 0.0015 \\
\hline $\pm 95 \%$ & 0.8 & -- & -- & 1.4 & 2.0 & 4.2 & 8.2 & 9.9 & 12.5 & 16.4 & 29.0 & 0.0 & 0.063 & 3.2 & 2.6 & - & 0.063 & 0.0026 \\
\hline \multicolumn{19}{|c|}{9 September $1998\left(36\right.$ days; $\left.I_{30}=14.75 \mathrm{~mm} / \mathrm{h} ; P=36.1 \mathrm{~mm}\right)$} \\
\hline 9 & 4.9 & -- & - & 0.3 & 2.4 & 6.9 & 21.8 & 23.3 & 22.3 & 18.1 & 0.0 & 0.0 & 0.011 & 1.6 & 2.1 & 5.0 & 0.011 & 0.00031 \\
\hline 10 & 0.1 & - & -- & 0.1 & 0.4 & 1.0 & 3.2 & 5.5 & 13.6 & 28.9 & 24.5 & 22.7 & 0.056 & 7.6 & 4.1 & 5.0 & 0.056 & 0.0016 \\
\hline 11 & 0.4 & - & -- & 0.2 & 0.5 & 1.3 & 7.7 & 12.6 & 30.4 & 47.0 & 0.0 & 0.0 & 0.011 & 3.8 & 1.0 & 5.0 & 0.011 & 0.00031 \\
\hline 12 & 4.1 & -- & -- & 0.4 & 2.0 & 5.2 & 15.8 & 22.3 & 28.5 & 21.7 & 0.0 & 0.0 & 0.022 & 2.0 & 2.7 & 5.0 & 0.022 & 0.00061 \\
\hline Mean & 2.4 & -- & -- & 0.2 & 1.3 & 3.6 & 12.1 & 15.9 & 23.7 & 28.9 & 6.1 & 5.7 & 0.025 & 3.8 & 2.5 & - & 0.025 & 0.00071 \\
\hline $\pm 95 \%$ & 3.5 & -- & - & 0.2 & 1.4 & 4.2 & 13.4 & 12.8 & 12.1 & 20.8 & 17.6 & 16.3 & 0.032 & 4.3 & 2.2 & -- & 0.032 & 0.00093 \\
\hline \multicolumn{19}{|c|}{26 May 1999 (259 days; rain gage was not maintained during part of collection interval) } \\
\hline 9 & 1.8 & -- & - & 2.4 & 2.1 & 6.5 & 9.0 & 18.4 & 30.9 & 22.0 & 6.8 & 0.0 & 0.059 & 2.6 & b & 5.0 & 0.059 & 0.00023 \\
\hline 10 & 0.6 & -- & - & 0.8 & 1.0 & 2.7 & 2.2 & 1.9 & 13.4 & 28.7 & 33.8 & 15.1 & 0.068 & 7.8 & $\mathrm{~b}$ & 5.0 & 0.068 & 0.00026 \\
\hline 11 & 0.3 & -- & -- & 0.3 & 0.3 & 1.1 & 2.8 & 8.6 & 27.3 & 35.3 & 24.1 & 0.0 & 0.067 & 5.0 & $\mathrm{~b}$ & 5.0 & 0.067 & 0.00026 \\
\hline 12 & 1.6 & -- & -- & 1.3 & 3.0 & 4.6 & 8.7 & 16.2 & 26.8 & 27.9 & 10.0 & 0.0 & 0.076 & 3.1 & b & 5.0 & 0.076 & 0.00029 \\
\hline Mean & 1.1 & & & 1.2 & 1.6 & 3.7 & 5.7 & 11.3 & 24.6 & 28.5 & 18.7 & 3.8 & 0.068 & 4.6 & -. & -- & 0.068 & 0.00026 \\
\hline $\pm 95 \%$ & 1.1 & & & 1.5 & 1.9 & 3.9 & 4.9 & 11.9 & 12.6 & 9.6 & 19.4 & 10.9 & 0.012 & 3.7 & -- & - & 0.012 & 0.000043 \\
\hline
\end{tabular}


Table 4.3. (Continued) Summary of particle-size distribution and the flux of sediment into north-facing hillslope traps in an unburned area of the Spring Creek watershed, 1998-2000

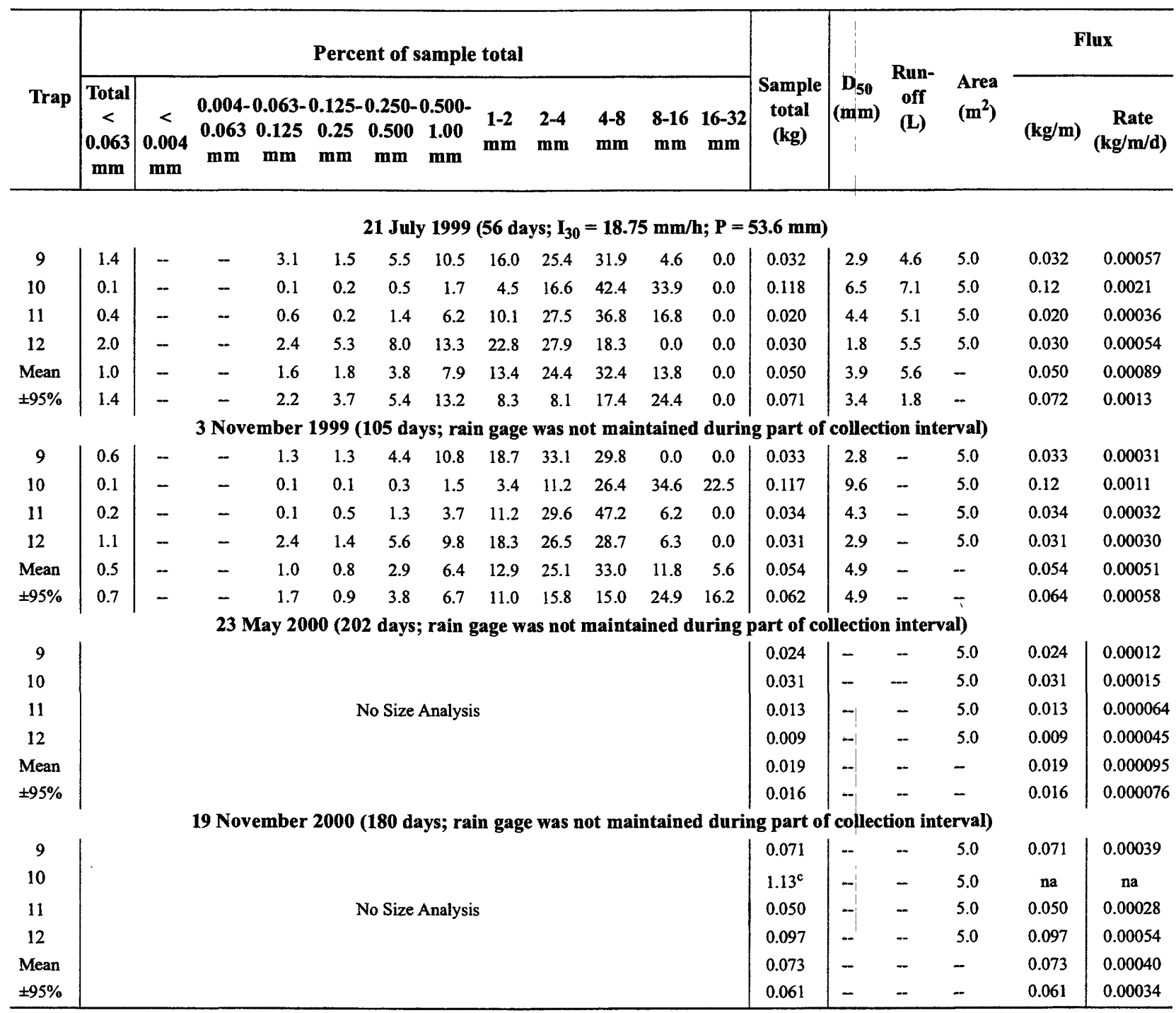

${ }^{\mathrm{a}} \mathrm{A}$ rain gage malfunctioned during the collection interval and this is the maximum $\mathrm{I}_{30}$ for the available data.

bNo runoff volumes were collected because this was the start of the rainfall sampling season and only the sediment from the winter season was collected.

${ }^{\mathrm{c}}$ This outlier was not included and the cause for an almost 300 -fold difference from the other 3 samples is unknown--vandalism is a possibility. 
Table 4.4. Summary of particle-size distribution and the flux of sediment into south-facing hillslope traps in an unburned area of the Spring Creek watershed, 1998-2000

[mm, millimeter; kg, kilogram; L, liter; $\mathrm{m}^{2}$, square meter; $\mathrm{kg} / \mathrm{m}$, kilogram per meter; $\mathrm{kg} / \mathrm{m} / \mathrm{d}$, kilogram per meter per day; days in parenthesis are the number of days between collection dates; $\mathrm{mm} / \mathrm{h}$, millimeter per hour; of, overflow; $\sim$, approximate; $\mathrm{I}_{30}$, maximum 30-minute rainfall intensity; $\mathrm{P}$, total rainfall; $\mathrm{I}_{30}$ and $\mathrm{P}$ calculated from data for a rain gage about 1.3 kilometers away from the traps and listed in U.S. Geological Survey 1997, 1998, 1999, and 2000; $\pm 95 \%, 95$-percent confidence limits; trap width was $1.00 \mathrm{~m}$ for all traps]

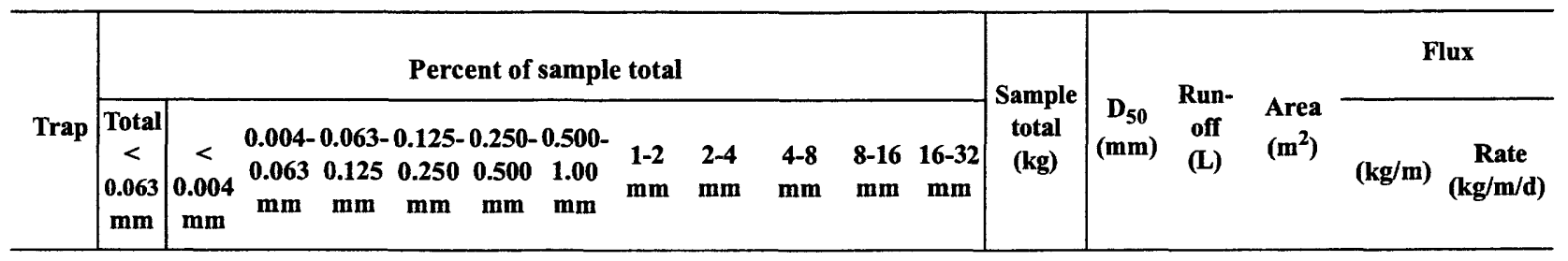

16 June 1998 (11 days; $\left.I_{30}=13.75 \mathrm{~mm} / \mathrm{h} ; P=14.7 \mathrm{~mm}\right)$

\begin{tabular}{|c|c|c|c|c|c|c|c|c|c|c|c|c|c|c|c|c|c|c|}
\hline 13 & 0.4 & $\ldots$ & - & 1.0 & 1.4 & 2.5 & 5.6 & 10.5 & 38.1 & 40.5 & 0.0 & 0.0 & 0.031 & 3.5 & 2.1 & 5.0 & 0.031 & 0.0028 \\
\hline 14 & 0.2 & -- & - & 0.3 & 0.6 & 0.9 & 1.5 & 3.6 & 18.4 & 74.5 & 0.0 & 0.0 & 0.043 & 5.3 & 3.2 & 5.0 & 0.043 & 0.0039 \\
\hline 15 & 0.2 & - & - & 0.4 & 0.7 & 1.2 & 1.8 & 4.2 & 22.2 & 69.3 & 0.0 & 0.0 & 0.039 & 5.1 & 1.5 & 5.0 & 0.039 & 0.0035 \\
\hline 16 & 0.7 & - & - & 2.6 & 4.3 & 6.0 & 12.9 & 26.5 & 26.6 & 20.5 & 0.0 & 0.0 & 0.010 & 1.9 & 0.6 & 5.0 & 0.010 & 0.00091 \\
\hline Mean & 0.4 & - & - & 1.1 & 1.8 & 2.6 & 5.4 & 11.2 & 26.3 & 51.2 & 0.0 & 0.0 & 0.031 & 4.0 & 1.8 & -- & 0.031 & 0.0028 \\
\hline $\pm 95 \%$ & 0.4 & - & - & 1.7 & 2.7 & 3.7 & 8.2 & 16.5 & 14.2 & 38.9 & 0.0 & 0.0 & 0.024 & 2.4 & 1.9 & - & 0.024 & 0.0022 \\
\hline
\end{tabular}

11 July 1998 (25 days; $I_{30}=7.50 \mathrm{~mm} / \mathrm{h}^{\mathrm{a}} ; P=21.1 \mathrm{~mm}$ )

\begin{tabular}{|c|c|c|c|c|c|c|c|c|c|c|c|c|c|c|c|c|c|c|}
\hline 13 & 2.5 & -- & - & 1.7 & 3.8 & 5.9 & 11.9 & 15.7 & 28.0 & 30.5 & 0.0 & 0.0 & 0.024 & 2.6 & 5.6 & 5.0 & 0.024 & 0.00096 \\
\hline 14 & 2.2 & -. & - & 1.1 & 1.6 & 2.8 & 3.3 & 6.0 & 22.0 & 36.3 & 24.7 & 0.0 & 0.018 & 5.2 & 6.1 & 5.0 & 0.018 & 0.00072 \\
\hline 15 & 0.7 & -- & - & 0.7 & 1.1 & 1.8 & 3.6 & 10.1 & 34.2 & 45.0 & 2.9 & 0.0 & 0.028 & 3.9 & 5.1 & 5.0 & 0.028 & 0.0011 \\
\hline 16 & 1.2 & -- & - & 1.2 & 2.9 & 7.0 & 9.9 & 22.1 & 28.5 & 22.7 & 4.6 & 0.0 & 0.017 & 2.4 & 2.5 & 5.0 & 0.017 & 0.00068 \\
\hline Mean & 1.6 & -- & .- & 1.2 & 2.4 & 4.4 & 7.2 & 13.5 & 28.2 & 33.6 & 8.0 & 0.0 & 0.022 & 3.5 & 4.8 & - & 0.022 & 0.00086 \\
\hline $\pm 95 \%$ & 1.3 & -- & - & 0.7 & 1.9 & 3.7 & 6.2 & 11.6 & 8.8 & 16.1 & 17.8 & 0.0 & 0.008 & 2.0 & 2.6 & - & 0.0079 & 0.00030 \\
\hline \multicolumn{19}{|c|}{4 August $1998\left(24\right.$ days; $\left.I_{30}=28.50 \mathrm{~mm} / \mathrm{h} ; P=69.1 \mathrm{~mm}\right)$} \\
\hline 13 & 1.1 & -- & - & 1.6 & 1.4 & 3.2 & 5.3 & 12.4 & 28.8 & 41.0 & 5.3 & 0.0 & 0.044 & 3.7 & 9.9 & 5.0 & 0.044 & 0.0018 \\
\hline 14 & 0.4 & -- & - & 0.6 & 0.4 & 1.2 & 2.5 & 10.3 & 36.1 & 44.5 & 4.2 & 0.0 & 0.052 & 3.9 & 8.1 & 5.0 & 0.052 & 0.0022 \\
\hline 15 & 0.2 & -- & - & 0.2 & 1.0 & 1.5 & 2.3 & 8.3 & 34.1 & 45.0 & 7.3 & 0.0 & 0.040 & 4.2 & 6.7 & 5.0 & 0.040 & 0.0017 \\
\hline 16 & 1.2 & - & -- & 1.6 & 1.2 & 4.1 & 8.5 & 21.0 & 27.3 & 24.4 & 10.7 & 0.0 & 0.032 & 2.9 & 3.5 & 5.0 & 0.032 & 0.0013 \\
\hline Mean & 0.7 & .. & -- & 1.0 & 1.0 & 2.5 & 4.6 & 13.0 & 31.6 & 38.7 & 6.9 & 0.0 & 0.042 & 3.7 & 7.0 & -- & 0.042 & 0.0018 \\
\hline $\pm 95 \%$ & 0.7 & - & - & 1.0 & 0.7 & 2.1 & 4.5 & 9.1 & 6.3 & 14.8 & 4.7 & 0.0 & 0.014 & 0.9 & 4.6 & -. & 0.014 & 0.00065 \\
\hline \multicolumn{19}{|c|}{9 September $1998\left(36\right.$ days; $\left.I_{30}=14.75 \mathrm{~mm} / \mathrm{h} ; P=36.1 \mathrm{~mm}\right)$} \\
\hline 13 & 0.3 & - & - & 0.4 & 1.0 & 2.0 & 3.1 & 7.1 & 24.8 & 41.0 & 20.4 & 0.0 & 0.032 & 5.1 & 8.9 & 5.0 & 0.032 & 0.00089 \\
\hline 14 & 0.6 & - & - & 0.1 & 0.2 & 0.9 & 2.2 & 9.2 & 30.3 & 49.0 & 7.4 & 0.0 & 0.037 & 4.5 & 5.8 & 5.0 & 0.037 & 0.0010 \\
\hline 15 & 0.3 & -. & -. & 0.3 & 0.6 & 1.1 & 1.9 & 7.0 & 32.0 & 48.4 & 8.4 & 0.0 & 0.026 & 4.6 & 5.0 & 5.0 & 0.026 & 0.00072 \\
\hline 16 & 2.7 & -- & -- & 0.0 & 1.2 & 4.5 & 14.4 & 33.3 & 33.2 & 10.9 & 0.0 & 0.0 & 0.009 & 1.8 & 1.9 & 5.0 & 0.0090 & 0.00025 \\
\hline Mean & 1.0 & -- & - & 0.2 & 0.8 & 2.1 & 5.4 & 14.2 & 30.1 & 37.3 & 9.0 & 0.0 & 0.026 & 4.0 & 5.4 & .. & 0.026 & 0.00072 \\
\hline $\pm 95 \%$ & 1.7 & -- & - & 0.3 & 0.7 & 2.6 & 9.0 & 18.9 & 6.0 & 27.4 & 14.7 & 0.0 & 0.020 & 2.4 & 5.0 & - & 0.020 & 0.00054 \\
\hline \multicolumn{19}{|c|}{26 May 1999 (259 days; rain gage was not maintained during part of collection interval) } \\
\hline 13 & 0.8 & -- & - & 1.6 & 0.6 & 3.2 & 5.2 & 11.1 & 30.0 & 37.9 & 9.5 & 0.0 & 0.038 & 3.8 & $\mathrm{~b}$ & 5.0 & 0.038 & 0.00015 \\
\hline 14 & 1.0 & -- & - & 1.5 & 0.5 & 2.3 & 3.6 & 10.3 & 23.9 & 38.6 & 18.3 & 0.0 & 0.055 & 4.7 & $\mathrm{~b}$ & 5.0 & 0.055 & 0.00021 \\
\hline 15 & 0.6 & -. & - & 0.9 & .0 .7 & 2.5 & 4.4 & 10.6 & 31.5 & 38.2 & 10.5 & 0.0 & 0.042 & 3.9 & $\mathrm{~b}$ & 5.0 & 0.042 & 0.00016 \\
\hline 16 & 1.8 & - & - & 1.4 & 2.8 & 4.1 & 8.3 & 18.3 & 27.4 & 26.8 & 9.2 & 0.0 & 0.099 & 3.1 & $\mathrm{~b}$ & 5.0 & 0.099 & 0.00038 \\
\hline ean & 1.0 & -- & - & 1.4 & 1.2 & 3.0 & 5.4 & 12.6 & 28.2 & 35.4 & 11.9 & 0.0 & 0.058 & 3.9 & .- & - & 0.058 & 0.00022 \\
\hline $\pm 95 \%$ & 0.9 & - & -. & 0.5 & 1.7 & 1.3 & 3.4 & 5.8 & 5.5 & 8.5 & 6.6 & 0.0 & 0.044 & 1.2 & - & -- & 0.044 & 0.00017 \\
\hline
\end{tabular}


Table 4.4. (Continued) Summary of particle-size distribution and the flux of sediment into south-facing hillslope traps in an unburned area of the Spring Creek watershed, 1998-2000

\begin{tabular}{|c|c|c|c|c|c|c|c|c|c|c|c|c|c|c|c|c|c|c|}
\hline \multirow{2}{*}{ Trap } & \multicolumn{12}{|c|}{ Percent of sample total } & \multirow{2}{*}{$\begin{array}{c}\text { Sample } \\
\text { total } \\
\text { (kg) }\end{array}$} & \multirow{2}{*}{$\begin{array}{c} \\
\mathbf{D}_{\mathbf{5 0}} \\
\mathbf{( m m )}\end{array}$} & \multirow{2}{*}{$\begin{array}{c}\text { Run- } \\
\text { off } \\
\text { (L) }\end{array}$} & \multirow{2}{*}{$\begin{array}{c}\text { Area } \\
\left(\mathbf{m}^{2}\right)\end{array}$} & \multicolumn{2}{|c|}{ Flux } \\
\hline & $\begin{array}{c}< \\
0.063 \\
\mathrm{~mm}\end{array}$ & $\begin{array}{c}< \\
0.004 \\
\mathrm{~mm}\end{array}$ & $\begin{array}{c}0.004- \\
0.063 \\
\mathrm{~mm}\end{array}$ & $\begin{array}{c}-0.063 \\
0.125 \\
\text { mm }\end{array}$ & $\begin{array}{c}0.125 \\
0.250 \\
\mathrm{~mm}\end{array}$ & $\begin{array}{c}-0.250- \\
0.500 \\
\mathrm{~mm}\end{array}$ & $\begin{array}{c}0.500- \\
1.00 \\
\mathrm{~mm}\end{array}$ & $\begin{array}{c}1-2 \\
\mathrm{~mm}\end{array}$ & $\begin{array}{l}2-4 \\
\mathrm{~mm}\end{array}$ & $\begin{array}{l}4-8 \\
\mathrm{~mm}\end{array}$ & $\begin{array}{l}8-16 \\
\mathrm{~mm}\end{array}$ & $\begin{array}{c}16-32 \\
\mathrm{~mm}\end{array}$ & & & & & $(\mathbf{k g} / \mathbf{m})$ & $\begin{array}{c}\text { Rate } \\
(\mathrm{kg} / \mathrm{m} / \mathrm{d})\end{array}$ \\
\hline \multicolumn{19}{|c|}{21 July 1999 (56 days; $\left.I_{30}=18.75 \mathrm{~mm} / \mathrm{h} ; P=53.6 \mathrm{~mm}\right)$} \\
\hline 13 & 0.5 & - & - & 0.9 & 0.3 & 1.9 & 3.5 & 7.3 & 22.8 & 41.2 & 21.7 & 0.0 & 0.074 & 5.2 & 10.7 & 5.0 & 0.074 & 0.0013 \\
\hline 14 & 0.4 & - & - & 0.3 & 0.7 & 1.3 & 2.8 & 7.4 & 21.4 & 50.7 & 15.0 & 0.0 & 0.077 & 5.2 & 8.7 & 5.0 & 0.077 & 0.0014 \\
\hline 15 & 0.3 & - & - & 0.5 & 0.2 & 1.0 & 2.3 & 10.3 & 26.7 & 48.1 & 10.6 & 0.0 & 0.085 & 4.7 & 12.0 & 5.0 & 0.085 & 0.0015 \\
\hline 16 & 1.8 & - & - & 1.6 & 3.4 & 5.0 & 9.5 & 22.8 & 30.8 & 25.2 & 0.0 & 0.0 & 0.045 & 2.4 & 4.0 & 5.0 & 0.045 & 0.00080 \\
\hline Mean & 0.8 & & & 0.8 & 1.2 & 2.3 & 4.5 & 12.0 & 25.4 & 41.3 & 11.8 & 0.0 & 0.070 & 4.4 & 8.9 & - & 0.070 & 0.0012 \\
\hline $\pm 95 \%$ & 1.1 & & & 0.9 & 2.3 & 2.9 & 5.2 & 11.2 & 6.8 & 18.4 & 15.6 & 0.0 & 0.029 & 2.1 & 5.8 & - & 0.029 & 0.00050 \\
\hline \multicolumn{19}{|c|}{3 November 1999 (105 days; rain gage was not maintained during part of collection interval } \\
\hline 13 & 0.5 & - & -- & 0.8 & 0.7 & 2.7 & 5.6 & 15.0 & 28.8 & 42.4 & 3.5 & 0.0 & 0.119 & 3.7 & -- & 5.0 & 0.12 & 0.0011 \\
\hline 14 & 0.4 & - & -- & 0.6 & 0.3 & 1.2 & 2.7 & 8.2 & 22.3 & 37.3 & 22.8 & 4.3 & 0.132 & 5.5 & -- & 5.0 & 0.13 & 0.0013 \\
\hline 15 & 0.3 & - & - & 0.5 & 0.3 & 1.4 & 3.5 & 12.0 & 33.9 & 41.1 & 6.8 & 0.0 & 0.098 & 3.9 & -- & 5.0 & 0.098 & 0.00093 \\
\hline 16 & 0.9 & - & - & 1.1 & 1.6 & 3.6 & 7.8 & 21.7 & 63.3 & 0.0 & 0.0 & 0.0 & 0.040 & 2.4 & -- & 5.0 & 0.040 & 0.00038 \\
\hline Mean & 0.5 & - & - & 0.8 & 0.7 & 2.2 & 4.9 & 14.2 & 37.1 & 30.2 & 8.3 & 1.1 & 0.097 & 3.9 & -- & - & 0.097 & 0.00093 \\
\hline $\pm 95 \%$ & 0.4 & - & - & 0.4 & 0.9 & 1.7 & 3.7 & 9.7 & 29.5 & 30.5 & 16.4 & 3.1 & 0.066 & 2.2 & -- & - & 0.066 & 0.00066 \\
\hline \multicolumn{19}{|c|}{23 May 2000 (202 days; rain gage was not maintained during part of collection interval) } \\
\hline 13 & \multirow{6}{*}{\multicolumn{12}{|c|}{ No Size Analysis }} & 0.022 & & -- & 5.0 & 0.022 & 0.00011 \\
\hline 14 & & & & & & & & & & & & & 0.016 & & -- & 5.0 & 0.016 & 0.000079 \\
\hline 15 & & & & & & & & & & & & & 0.019 & , & -- & 5.0 & 0.019 & 0.000094 \\
\hline 16 & & & & & & & & & & & & & 0.028 & & -- & 5.0 & 0.028 & 0.00014 \\
\hline Mean & & & & & & & & & & & & & 0.021 & & -- & - & 0.021 & 0.00011 \\
\hline $\pm 95 \%$ & & & & & & & & & & & & & 0.009 & & -- & -- & 0.0086 & 0.000044 \\
\hline \multicolumn{19}{|c|}{19 November 2000 (180 days; ram gage was not maintained during part of collection interval) } \\
\hline 13 & \multirow{6}{*}{\multicolumn{12}{|c|}{ No Size Analysis }} & 0.332 & & -. & 5.0 & 0.33 & 0.0018 \\
\hline 14 & & & & & & & & & & & & & 0.254 & । & - & 5.0 & 0.25 & 0.0014 \\
\hline 15 & & & & & & & & & & & & & 0.253 & & - & 5.0 & 0.25 & 0.0014 \\
\hline 16 & & & & & & & & & & & & & 0.084 & & -- & 5.0 & 0.084 & 0.00047 \\
\hline Mean & & & & & & & & & & & & & 0.231 & & - & - & 0.23 & 0.0013 \\
\hline $\pm 95 \%$ & & & & & & & & & & & & & 0.179 & & -- & - & 0.18 & 0.00096 \\
\hline
\end{tabular}

\footnotetext{
${ }^{a} \mathrm{~A}$ rain gage malfunctioned during the collection interval; this is the maximum $\mathrm{I}_{30}$ for the available data.

bo runoff volumes were collected because this was the start of the rainfall sampling season and only the sediment from the winter season was collected.
} 


\section{Table 4.5. Summary of the seasonal flux of sediment into hillslope traps in a severely burned and an unburned area of the Spring Creek watershed, 1997-2000}

[Years are water years (October through September); total summer precipitation was measured at Spring Creek above mouth near South Platte for June, July, August, and September and therefore, summer is 122 days; normalized summer flux has been normalized by the total summer precipitation; \pm indicates $95 \%$ confidence limits; mm, millimeter; $\mathrm{kg} / \mathrm{m} / \mathrm{d}$, kilogram per meter per day; $\mathrm{kg} / \mathrm{m}$, kilogram per meter; $\mathrm{kg} / \mathrm{m} / \mathrm{mm}$, kilogram per meter per millimeter of rainfall]

\begin{tabular}{|c|c|c|c|c|c|c|c|c|}
\hline & \multicolumn{4}{|c|}{ North-facing severely burned hillslope } & \multicolumn{4}{|c|}{ South-facing severely burned hillslope } \\
\hline & 1997 & 1998 & 1999 & 2000 & 1997 & 1998 & 1999 & 2000 \\
\hline $\begin{array}{l}\text { Total summer precipitation } \\
(\mathrm{mm})\end{array}$ & 250 & 151 & 153 & 185 & 250 & 151 & 153 & 185 \\
\hline Number of winter samples & na & $1^{\mathrm{a}}$ & 1 & 1 & na & $1^{\mathrm{a}}$ & $3^{b}$ & 1 \\
\hline Number of summer samples & 7 & 4 & 2 & 1 & 7 & 4 & 2 & 1 \\
\hline $\begin{array}{l}\text { Average mean winter flux rate } \\
(\mathrm{kg} / \mathrm{m} / \mathrm{d})\end{array}$ & na & 0.00037 & 0.00022 & 0.000070 & na & 0.0010 & $\begin{array}{r}0.00034 \\
\pm 0.00039\end{array}$ & 0.00031 \\
\hline $\begin{array}{l}\text { Average mean summer flux rate } \\
(\mathrm{kg} / \mathrm{m} / \mathrm{d})\end{array}$ & 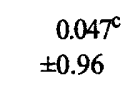 & $\begin{array}{r}0.0025 \\
\pm 0.0031\end{array}$ & $\begin{array}{l}0.00086 \\
\pm 0.0056\end{array}$ & 0.00064 & $\begin{array}{l}0.0077^{\mathrm{c}} \\
\pm 0.17\end{array}$ & $\begin{array}{r}0.0012 \\
\pm 0.0012\end{array}$ & $\begin{array}{r}0.0007 \\
\pm 0.0042\end{array}$ & 0.00045 \\
\hline $\begin{array}{l}\text { Winter flux ( } 243 \text { days }) \\
(\mathrm{kg} / \mathrm{m})\end{array}$ & na & 0.090 & 0.053 & 0.017 & na & 0.24 & $\begin{array}{l}0.083 \\
\pm 1.0\end{array}$ & 0.075 \\
\hline $\begin{array}{l}\text { Summer flux (122 days) } \\
(\mathrm{kg} / \mathrm{m})\end{array}$ & $\begin{aligned} &>5.7 \\
& \pm 120\end{aligned}$ & $\begin{array}{r}0.30 \\
\pm 0.38\end{array}$ & $\begin{array}{r}0.10 \\
\pm 0.68\end{array}$ & 0.078 & $\begin{aligned} & 0.94 \\
\pm & 21\end{aligned}$ & $\begin{array}{r}0.15 \\
\pm 0.15\end{array}$ & $\begin{array}{r}0.12 \\
\pm 0.51\end{array}$ & 0.055 \\
\hline $\begin{array}{l}\text { Normalized summer flux } \\
\left(\mathrm{kg} / \mathrm{m}^{\prime} \mathrm{mm}\right)\end{array}$ & $\begin{array}{l}0.023 \\
\pm 0.48\end{array}$ & $\begin{array}{r}0.0020 \\
\pm 0.0025\end{array}$ & $\begin{array}{l}0.00065 \\
\pm 0.0044\end{array}$ & 0.00042 & $\begin{array}{l}0.0038 \\
\pm 0.083\end{array}$ & $\begin{array}{r}0.00099 \\
\pm 0.00099\end{array}$ & $\begin{array}{l}0.00078 \\
\pm 0.0033\end{array}$ & 0.00030 \\
\hline
\end{tabular}

North-facing unburned hillslope

Number of winter samples

Number of summer samples

Average mean winter flux rate $(\mathrm{kg} / \mathrm{m} / \mathrm{d})$

Average mean summer flux rate $(\mathrm{kg} / \mathrm{m} / \mathrm{d})$

Winter flux (243 days)

$(\mathrm{kg} / \mathrm{m})$

Summer flux (122 days)

$(\mathrm{kg} / \mathrm{m})$

Normalized summer flux $(\mathrm{kg} / \mathrm{m} / \mathrm{mm})$

na na 11

$\begin{array}{llll}\text { na } & 4 & 2 & 1\end{array}$

$\begin{array}{llll}\text { na } & \text { na } & 0.00026 & 0.000095\end{array}$

na $\quad 0.0012 \quad 0.00070 \quad 0.00040$

na

na

0.063

0.023

na

0.15

$\pm 0.095 \pm 0.29$

0.049

$\begin{array}{llll}\text { na } & 0.00099 & 0.00056 & 0.00026\end{array}$

$\pm 0.00063 \pm 0.0019$ $\pm 0.00078 \pm 0.0024$
South-facing unburned hillslope

\begin{tabular}{|c|c|c|c|}
\hline na & na & 1 & 1 \\
\hline na & 4 & 2 & 1 \\
\hline na & na & 0.00022 & 0.00011 \\
\hline na & $\begin{array}{r}0.0015 \\
\pm 0.0012\end{array}$ & $\begin{array}{r}0.0011 \\
\pm 0.0017\end{array}$ & 0.0013 \\
\hline na & na & 0.053 & 0.027 \\
\hline na & $\begin{array}{r}0.18 \\
\pm 0.15\end{array}$ & $\begin{array}{r}0.13 \\
\pm 0.21\end{array}$ & 0.16 \\
\hline na & $\begin{array}{c}0.0012 \\
\pm 0.00099\end{array}$ & $\begin{array}{r}0.00085 \\
\pm 0.0014\end{array}$ & 0.00086 \\
\hline
\end{tabular}

\footnotetext{
${ }^{a}$ The 2 October 1997 sample was used to estimate winter rates during 1997 water year.

${ }^{\mathrm{b}}$ This includes 16 November 1998, 5 May 1999, and 26 May 1999.

'The sample collected on 04 September 1997 included the big storm of 31 August 1997. To calculate the average, the 31 August 1997 sample mean was weighted by 1 day and the average of the 7 other sample means were weighted by 121 days. The large difference between the 31 August 1997 sample and the other samples results in large values for the 95-percent confidence limits.
} 
Table 4.6. Summary of particle-size distribution of hillslope material in the Spring Creek and the Buffalo Creek watersheds

$[\sim$ = approximately; trough refers to the hillslope sediment traps where nearby soil samples were collected; cores were $10-\mathrm{cm}$ long and 5-cm in diameter; $\mathrm{mm}$, millimeter; $\mathrm{D}_{50}$ is the median diameter; C.I., 95-percent confidence limits]

\begin{tabular}{|c|c|c|c|c|c|c|c|c|c|c|c|c|}
\hline \multirow[b]{2}{*}{ Description } & \multicolumn{10}{|c|}{ Percent of total } & \multirow[b]{2}{*}{$\begin{array}{l}\mathbf{D}_{\mathbf{5 0}} \\
(\mathbf{m m})\end{array}$} & \multirow[b]{2}{*}{ Comment } \\
\hline & $\begin{array}{c}< \\
0.063 \\
\mathbf{m m}\end{array}$ & $\begin{array}{c}0.063 \\
- \\
0.125 \\
\mathrm{~mm}\end{array}$ & $\begin{array}{c}0.125 \\
- \\
0.250 \\
\mathrm{~mm}\end{array}$ & $\begin{array}{c}0.250 \\
- \\
0.500 \\
\text { mm }\end{array}$ & $\begin{array}{c}0.500 \\
-1.00 \\
\mathrm{~mm}\end{array}$ & $\begin{array}{l}1-2 \\
\mathrm{~mm}\end{array}$ & $\begin{array}{c}2-4 \\
\mathrm{~mm}\end{array}$ & $\begin{array}{l}4-8 \\
\mathrm{~mm}\end{array}$ & $\begin{array}{l}8-16 \\
\mathrm{~mm}\end{array}$ & $\begin{array}{c}16-32 \\
\mathrm{~mm}\end{array}$ & & \\
\hline \multicolumn{13}{|c|}{ Unburned hillslope soil samples in the Spring Creek watershed } \\
\hline Trough 9 & 5.9 & 3.2 & 2.4 & 7.6 & 10.9 & 14.9 & 17.7 & 26.0 & 11.4 & 0.0 & 2.6 & North; 3 cores \\
\hline Trough 10 & 5.4 & 2.9 & 2.3 & 4.9 & 7.4 & 12.0 & 21.0 & 25.9 & 18.1 & 0.0 & 3.4 & North; 3 cores \\
\hline Trough 11 & 7.6 & 3.2 & 4.6 & 6.2 & 9.0 & 16.0 & 21.3 & 22.9 & 9.1 & 0.0 & 2.3 & North; 3 cores \\
\hline Trough 12 & 9.1 & 4.4 & 3.3 & 6.6 & 8.4 & 14.8 & 21.4 & 21.8 & 10.3 & 0.0 & 2.3 & North; 3 cores \\
\hline Mean & 7.0 & 3.4 & 3.2 & 6.3 & 8.9 & 14.4 & 20.4 & 24.2 & 12.2 & 0.0 & 2.6 & - \\
\hline C.I. & 2.7 & 1.1 & 1.7 & 1.9 & 2.5 & 2.9 & 2.7 & 3.0 & 6.5 & 0.0 & 0.8 & -- \\
\hline Trough 13 & 5.7 & 3.8 & 1.4 & 5.7 & 7.3 & 13.1 & 21.4 & 25.0 & 15.1 & 1.5 & 3.2 & South; 3 cores \\
\hline Trough 14 & 8.0 & 2.3 & 2.6 & 3.7 & 6.0 & 14.1 & 27.5 & 26.9 & 7.8 & 1.1 & 3.0 & South; 3 cores \\
\hline Trough 15 & 7.8 & 4.8 & 2.8 & 8.2 & 9.8 & 15.4 & 22.8 & 20.4 & 7.0 & 1.0 & 2.1 & South; 3 cores \\
\hline Trough 16 & 4.0 & 3.0 & 2.0 & 6.3 & 8.6 & 13.2 & 18.6 & 26.3 & 15.6 & 2.5 & 3.4 & South; 3 cores \\
\hline Mean & 6.4 & 3.5 & 2.2 & 6.0 & 7.9 & 14.0 & 22.6 & 24.6 & 11.4 & 1.5 & 2.9 & - \\
\hline C. I. & 2.9 & 1.8 & 1.0 & 3.2 & 2.7 & 1.7 & 6.4 & 4.7 & 6.2 & 1.1 & 0.9 & - \\
\hline \multicolumn{13}{|c|}{ Burned hillslope soil samples in the Spring Creek watershed } \\
\hline Core 5 & 13.8 & 3.4 & 4.2 & 5.5 & 6.2 & 9.4 & 15.6 & 20.0 & 13.8 & 8.1 & 3.0 & North; 1 core \\
\hline Core 6 & 13.6 & 6.2 & 6.6 & 7.8 & 7.7 & 9.9 & 14.6 & 18.5 & 15.3 & 0.0 & 1.6 & North; 1 core \\
\hline Core 7 & 10.6 & 4.9 & 6.7 & 8.4 & 10.2 & 14.6 & 19.6 & 17.2 & 7.7 & 0.0 & 1.6 & North; 1 core \\
\hline Core 8 & 11.6 & 3.2 & 4.8 & 6.3 & 8.0 & 12.3 & 18.3 & 20.6 & 14.8 & 0.0 & 2.4 & North; 1 core \\
\hline Sci-5 & 12.2 & 3.6 & 4.3 & 4.7 & 5.6 & 9.2 & 16.6 & 24.9 & 19.0 & 0.0 & 3.3 & North; 1 core \\
\hline Mean & 12.4 & 4.3 & 5.3 & 6.5 & 7.5 & 11.1 & 16.9 & 20.2 & 14.1 & 1.6 & 2.4 & - \\
\hline C. I. & 1.6 & 1.5 & 1.3 & 1.9 & 2.3 & 2.8 & 2.6 & 3.9 & 5.8 & 4.1 & 0.9 & - \\
\hline Core 1 & 6.9 & 1.5 & 3.1 & 5.3 & 7.5 & 12.3 & 20.4 & 27.3 & 13.0 & 2.8 & 3.3 & South; 1 core \\
\hline Core 2 & 9.9 & 3.5 & 5.3 & 6.6 & 8.3 & 14.7 & 21.6 & 23.4 & 6.6 & 0.0 & 2.2 & South; 1 core \\
\hline Core 3 & 11.1 & 3.2 & 5.1 & 6.2 & 8.6 & 14.8 & 20.9 & 22.1 & 8.0 & 0.0 & 2.1 & South; 1 core \\
\hline Core 4 & 8.6 & 3.3 & 4.9 & 6.2 & 8.0 & 13.8 & 22.1 & 24.0 & 5.6 & 3.5 & 2.5 & South; 1 core \\
\hline Sci-1 & 8.5 & 3.1 & 4.8 & 6.8 & 8.6 & 13.5 & 20.4 & 25.1 & 9.3 & 0.0 & 2.5 & South; 1 core \\
\hline Sci-2 & 15.3 & 3.6 & 4.1 & 5.7 & 7.9 & 12.4 & 16.4 & 19.3 & 15.4 & 0.0 & 2.1 & South; 1 core \\
\hline Sci-3 & 10.2 & 2.5 & 3.5 & 4.9 & 6.8 & 11.2 & 16.7 & 22.5 & 21.8 & 0.0 & 3.3 & South; 1 core \\
\hline Sci-4 & 11.5 & 2.4 & 3.6 & 4.4 & 7.1 & 14.2 & 23.0 & 22.7 & 11.3 & 0.0 & 2.6 & South; 1 core \\
\hline Mean & 10.2 & 2.9 & 4.3 & 5.8 & 7.8 & 13.4 & 20.2 & 23.3 & 11.4 & 0.8 & 2.6 & \\
\hline C. I. & 2.4 & 0.6 & 0.6 & 0.7 & 0.5 & 1.0 & 1.9 & 2.3 & 4.7 & 1.0 & 0.3 & \\
\hline \multicolumn{13}{|c|}{ Unburned hillslope soil sample in Buffalo Creek watershed } \\
\hline $\begin{array}{l}\text { Shinglemill } \\
\text { Creek }\end{array}$ & 10.7 & 5.9 & 8.3 & 11.1 & 10.2 & 15.1 & 14.1 & 10.2 & 6.2 & 8.2 & 1.3 & $\begin{array}{l}\text { Area adjacent to burned area; } \\
\text { surface sample }\end{array}$ \\
\hline \multicolumn{13}{|c|}{ Burned hillslope soil samples in Buffalo Creek watershed } \\
\hline Tributary 3.1 & 15.3 & 6.7 & 10.3 & 6.5 & 9.9 & 16.8 & 15.3 & 14.1 & 5.1 & 0.0 & 1.1 & $\begin{array}{l}\text { Ridge crest in burned area; } \\
\text { surface sample }\end{array}$ \\
\hline Sand Draw & 3.3 & 3.8 & 7.0 & 9.0 & 14.4 & 18.6 & 22.2 & 16.8 & 5.0 & 0.0 & 1.7 & Left bank; surface sample \\
\hline Tributary 3.1 & 3.5 & 3.2 & 4.0 & 5.7 & 10.8 & 21.2 & 28.7 & 16.2 & 6.7 & 0.0 & 2.1 & $\begin{array}{l}\text {-100 m upstream on right } \\
\text { bank; surface sample }\end{array}$ \\
\hline Mean & 7.4 & 4.6 & 7.1 & 7.1 & 11.7 & 18.9 & 22.1 & 15.7 & 5.6 & 0.0 & 1.6 & - \\
\hline C.I. & 15.7 & 4.6 & 8.2 & 4.3 & 5.8 & 5.7 & 17.4 & 3.4 & 2.3 & 0.0 & 5.4 & - \\
\hline
\end{tabular}




\section{Table 4.7. Sediment size and flux data for rill traps on a south-facing hillslope in the Spring}

\section{Creek watershed}

[D, distance from start of rill; $\mathrm{W}$, top width; $\mathrm{P}$, total rainfall; $\mathrm{I}_{30}$, maximum 30 -minutes rainfall intensity during collection interval; V, runoff volume; $\mathrm{m}$, meter; $\mathrm{mm}$, millimeter, L, liter; $\mathrm{kg}$, kilogram; $\mathrm{kg} / \mathrm{m}$, kilogram per meter]

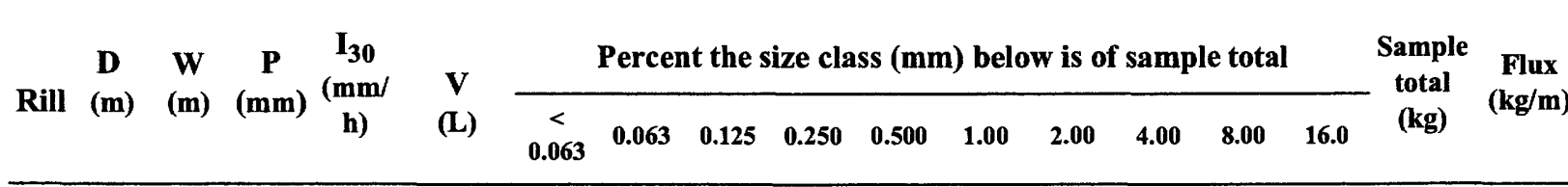

\begin{tabular}{|c|c|c|c|c|c|c|c|c|c|c|c|c|c|c|c|c|c|}
\hline \multicolumn{18}{|c|}{16 June 1998} \\
\hline A & 4 & 0.61 & 14.7 & 13.75 & 0.050 & 2.9 & 2.9 & 4.9 & 9.8 & 15.7 & 26.5 & 21.6 & 15.7 & 0.0 & 0.0 & 0.010 & 0.016 \\
\hline B & 8 & 0.37 & 14.7 & 13.75 & 0.160 & 4.7 & 5.3 & 0.6 & 7.8 & 15.6 & 26.5 & 25.2 & 14.3 & 0.0 & 0.0 & 0.032 & 0.086 \\
\hline $\mathrm{C}$ & 14 & 0.65 & 14.7 & 13.75 & 0.640 & 4.3 & 1.4 & 1.9 & 3.5 & 6.6 & 13.2 & 20.6 & 23.3 & 25.2 & 0.0 & 0.051 & 0.078 \\
\hline \multicolumn{18}{|c|}{11 July 1998} \\
\hline A & 4 & 0.61 & 21.1 & 7.50 & 0.130 & 4.3 & 4.3 & 6.5 & 10.9 & 15.2 & 21.7 & 28.3 & 8.7 & 0.0 & 0.0 & 0.005 & 0.0075 \\
\hline B & 8 & 0.37 & 21.1 & 7.50 & 0.0 & 2.4 & 3.6 & 3.2 & 9.6 & 13.5 & 20.3 & 21.9 & 25.5 & 0.0 & 0.0 & 0.025 & 0.068 \\
\hline $\mathrm{C}$ & 14 & 0.65 & 21.1 & 7.50 & 0.020 & 1.8 & 1.5 & 0.9 & 3.6 & 6.8 & 14.8 & 23.7 & 24.6 & 22.3 & 0.0 & 0.034 & 0.052 \\
\hline \multicolumn{18}{|c|}{4 August 1998} \\
\hline A & 4 & 0.61 & 69.1 & 28.50 & 2.320 & 6.5 & 2.1 & 4.0 & 7.7 & 11.6 & 22.3 & 21.9 & 9.1 & 1.6 & 13.3 & 0.043 & 0.070 \\
\hline B & 8 & 0.47 & 69.1 & 28.50 & 8.320 & 8.0 & 3.5 & 4.5 & 8.1 & 13.8 & 21.4 & 23.5 & 12.6 & 4.5 & 0.0 & 0.170 & 0.36 \\
\hline $\mathrm{C}$ & 14 & 0.64 & 69.1 & 28.50 & 6.035 & 8.0 & 1.7 & 2.7 & 4.7 & 7.8 & 15.2 & 23.1 & 20.9 & 15.9 & 0.0 & 0.154 & 0.24 \\
\hline \multicolumn{18}{|c|}{9 September 1998} \\
\hline A & 4 & 0.61 & 36.1 & 14.75 & 2.580 & 3.1 & 1.8 & 3.7 & 7.4 & 12.0 & 19.9 & 25.8 & 17.8 & 8.6 & 0.0 & 0.033 & 0.054 \\
\hline B & 8 & 0.47 & 36.1 & 14.75 & 3.680 & 13.7 & 2.3 & 3.3 & 7.4 & 11.7 & 18.1 & 22.5 & 15.2 & 5.8 & 0.0 & 0.110 & 0.23 \\
\hline $\mathrm{C}$ & 14 & 0.64 & 36.1 & 14.75 & 1.935 & 2.8 & 1.1 & 1.9 & 4.0 & 6.9 & 13.6 & 22.4 & 27.6 & 19.8 & 0.0 & 0.093 & 0.15 \\
\hline \multicolumn{18}{|c|}{16 November 1998} \\
\hline A & 4 & 0.61 & \multirow{3}{*}{\multicolumn{2}{|c|}{$\begin{array}{l}\text { rain gage } \\
\text { was not } \\
\text { maintained } \\
\text { continuously }\end{array}$}} & 1.060 & 1.4 & 4.3 & 1.4 & 7.1 & 11.4 & 17.1 & 24.3 & 32.9 & 0.0 & 0.0 & 0.007 & 0.010 \\
\hline B & 8 & 0.48 & & & 4.575 & 1.4 & 1.7 & 4.0 & 6.9 & 8.6 & 11.8 & 17.0 & 37.8 & 10.7 & 0.0 & 0.035 & 0.073 \\
\hline $\mathrm{C}$ & 14 & 0.64 & & & 3.680 & 0.4 & 0.6 & 0.5 & 1.3 & 2.3 & 4.9 & 12.5 & 40.2 & 37.4 & 0.0 & 0.168 & 0.26 \\
\hline
\end{tabular}

\section{May 1999}

$$
\begin{array}{lrrcr}
\text { A } & 4 & 0.59 & \text { rain gage } & 15.920 \\
\text { B } & 8 & 0.50 & \begin{array}{c}
\text { was not } \\
\text { maintained }
\end{array} & 6.150 \\
\text { C } & 14 & 0.65 & \text { continuously } & 18.745
\end{array}
$$

$\begin{array}{rrrrrr}\text { A } & 4 & 0.59 & 80.5 & 7.75 & 7.400 \\ \text { B } & 8 & 0.50 & 80.5 & 7.75 & 4.050 \\ \text { C } & 14 & 0.65 & 80.5 & 7.75 & 3.950\end{array}$

$\begin{array}{rrrrrrrrrrrl}1.7 & 2.1 & 1.3 & 3.8 & 6.4 & 10.6 & 18.6 & 37.3 & 18.2 & 0.0 & 0.024 & 0.041 \\ 1.7 & 2.4 & 2.2 & 5.7 & 8.0 & 12.1 & 15.8 & 26.5 & 25.6 & 0.0 & 0.086 & 0.17 \\ 0.6 & 0.3 & 0.8 & 1.3 & 2.3 & 4.4 & 11.8 & 37.4 & 31.1 & 10.1 & 0.184 & 0.28\end{array}$

21 June 1999

$$
\begin{array}{ll}
\text { no sediment was observed } & 0.00 \\
\text { no sediment was observed } & 0.00 \\
\text { no sediment was observed } & 0.00
\end{array}
$$

\section{July 1999}

$\begin{array}{rrrrrrrrrrrr}37.3 & 7.0 & 6.3 & 6.3 & 7.1 & 11.2 & 13.0 & 9.4 & 2.4 & 0.0 & 0.214 & 0.43 \\ 10.9 & 3.9 & 4.0 & 4.9 & 6.9 & 11.8 & 19.9 & 24.0 & 13.4 & 0.3 & 8.454 & 17 . \\ 12.6 & 4.1 & 4.4 & 5.5 & 8.0 & 12.8 & 20.9 & 22.4 & 8.8 & 0.6 & 9.912 & 22\end{array}$


Table 4.7. (Continued) Sediment size and flux data for rill traps on a south-facing hillslope in the Spring Creek watershed

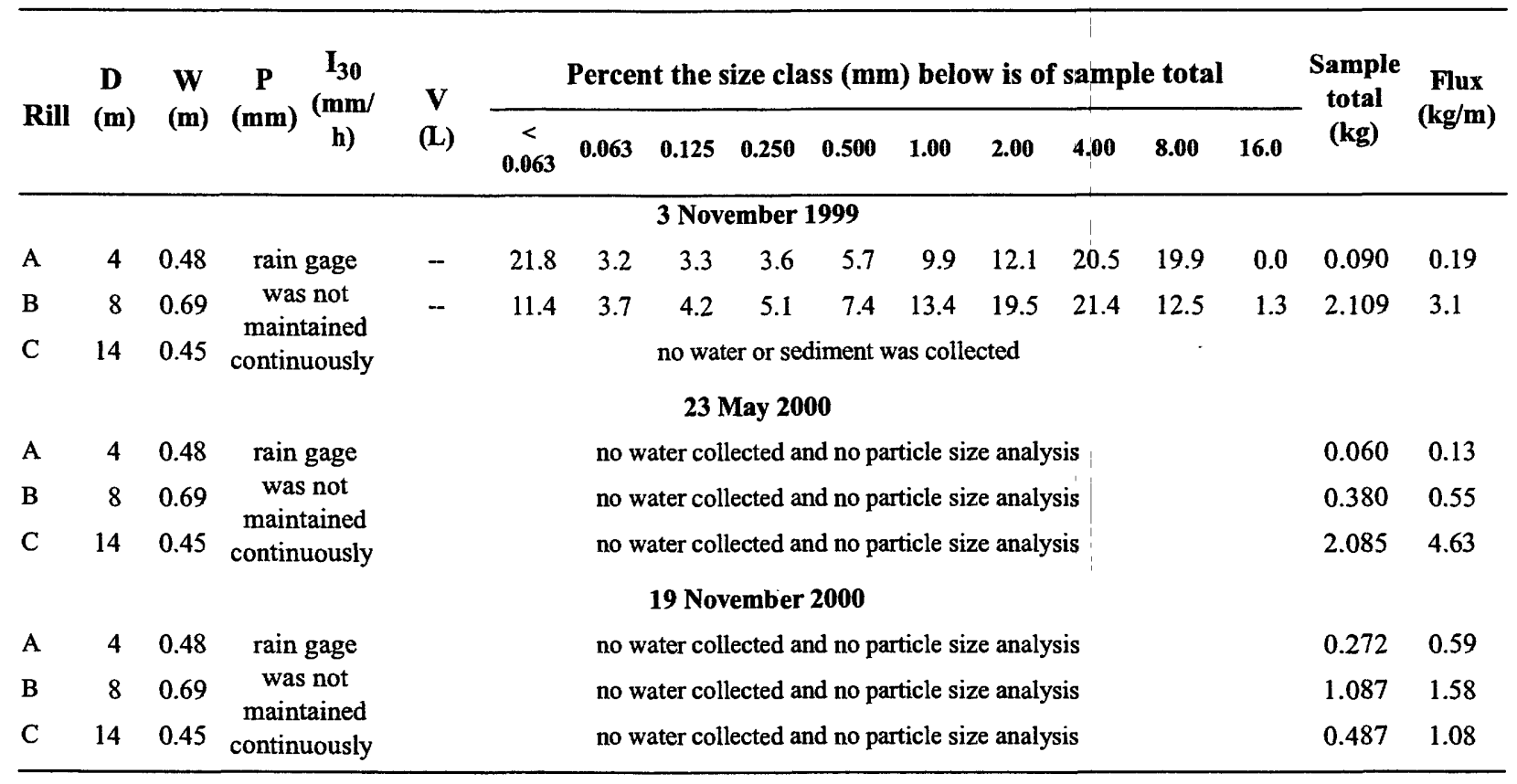

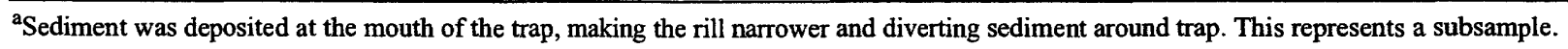


Table 4.8. Comparison of the geometry of hydraulic channels formed by unsteady and steady flow processes

[c.l., confidence limits; WDR, mean width to depth ratio; A, cross-sectional area; m, meter]

\begin{tabular}{|c|c|c|c|c|c|c|c|}
\hline \multirow[b]{2}{*}{ Channel } & \multirow[b]{2}{*}{ Number } & \multirow{2}{*}{$\begin{array}{c}\text { Typical } \\
\text { channel } \\
\text { slope }\end{array}$} & \multirow{2}{*}{$\begin{array}{l}\text { Top } \\
\text { width } \\
\text { (m) }\end{array}$} & \multirow{2}{*}{$\begin{array}{c}\text { WDR } \\
\pm 95 \% \text { c.l. }\end{array}$} & \multicolumn{2}{|c|}{$\begin{array}{c}\text { Shape } \\
\text { Hydraulic radius }=\mathrm{cA}^{\mathrm{b}}\end{array}$} & \multirow{2}{*}{ References } \\
\hline & & & & & c $\pm 95 \%$ c.I. & b $\pm 95 \% c . I$. & \\
\hline $\begin{array}{l}\text { Rills on burned } \\
\text { mountain slopes }\end{array}$ & 71 & 0.40 & $0.20-1.10$ & $7 \pm 1.2$ & $0.22 \pm 0.01$ & $0.55 \pm 0.02$ & This study. \\
\hline Agricultural Rills & 6 & 0.07 & $0.14-0.16$ & $25 \pm 4.6$ & no data & no data & Elliot and others, 1989. \\
\hline \multirow[t]{2}{*}{ Agricultural Rills } & unknown & 0.06 & no data & no data & 0.50 & 0.64 & Moore and Foster, 1990. \\
\hline & & & & & 0.44 & 0.53 & Moore and Foster, 1990. \\
\hline Rangeland Rills & 7 & 0.03 & $0.20--0.60$ & $31 \pm 11$ & $0.18 \pm 0.09$ & $0.52 \pm 0.09$ & $\begin{array}{l}\text { Abrahams and others, } \\
\text { 1996, Table III. }\end{array}$ \\
\hline Powder River & 20 & 0.001 & $90--260$ & $49 \pm 10$ & $0.08 \pm 0.02$ & $0.60 \pm 0.06$ & Moody and Meade, 1990. \\
\hline Mississippi River & 8 & 0.00001 & $510--1210$ & $58 \pm 15$ & $0.05 \pm 0.03$ & $0.58 \pm 0.06$ & Moody and Meade, 1993. \\
\hline
\end{tabular}


Table 4.9. Summary of cross-sectional area of rills in the Spring Creek watershed

$\left[\mathrm{m}^{2}\right.$, square meter]

\begin{tabular}{|c|c|c|c|c|}
\hline Location & $\begin{array}{l}\text { Mean cross- } \\
\text { sectional } \\
\text { area } \\
\left(\mathrm{m}^{2}\right)\end{array}$ & $\begin{array}{l}\text { Standard devia- } \\
\text { tion of the } \\
\text { mean cross-sec- } \\
\text { tional area } \\
\left(\mathbf{m}^{2}\right)\end{array}$ & $\begin{array}{c}\text { Number } \\
\text { of mea- } \\
\text { sure- } \\
\text { ments }\end{array}$ & Comments \\
\hline \multicolumn{5}{|c|}{ South-facing Hillslopes } \\
\hline Rill field near hillslope traps & 0.027 & 0.020 & 86 & $\begin{array}{l}\text { Width and maximum depth were measured } \\
\text { along transects spaced } 10 \mathrm{~m} \text { apart down a } \\
\text { south-facing hillslope (see map of rill field } \\
\text { in Figure } 4.4 \text { ). }\end{array}$ \\
\hline Rills A, B, C & 0.026 & 0.021 & 27 & $\begin{array}{l}\text { Detailed cross sections were measured using } \\
\text { an erosion bridge (see Table 4.7, Figure 4.5, } \\
\text { and Appendix 2). }\end{array}$ \\
\hline $\begin{array}{l}\text { Rills } D \text { and } E \text { in watershed } 1530 \\
\text { and Rill } 5 \text { in watershed } 1700\end{array}$ & 0.024 & 0.019 & 23 & $\begin{array}{l}\text { Measured detailed cross sections using an ero } \\
\text { sion bridge on a southwest-facing hillslope. }\end{array}$ \\
\hline Rill field in watershed 1530 & 0.010 & 0.0063 & 80 & $\begin{array}{l}\text { Measured several depths across each rill along } \\
\text { transects spaced } 5 \mathrm{~m} \text { apart down a south- } \\
\text { west-facing hillslope. }\end{array}$ \\
\hline Rill 4 in watershed 1530 & 0.052 & 0.047 & 8 & $\begin{array}{l}\text { Measured detailed cross sections using an ero- } \\
\text { sion bridge on a southeast-facing hillslope. }\end{array}$ \\
\hline Watershed 960 & 0.0085 & 0.0082 & 108 & $\begin{array}{l}\text { On } 22 \text { different hillslopes, width and maxi- } \\
\text { mum depth were measured every } 5 \mathrm{~m} \text { fol- } \\
\text { lowing the rill. }\end{array}$ \\
\hline South mean & 0.017 & & 332 & \\
\hline & \multicolumn{3}{|c|}{ North-facing Hillslopes } & 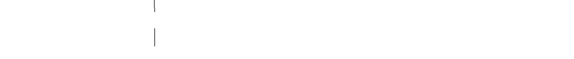 \\
\hline Watershed 1165 & 0.029 & 0.036 & 96 & $\begin{array}{l}\text { Width and maximum depth were measured on } \\
\text { several different hillslopes within this sub- } \\
\text { watershed. }\end{array}$ \\
\hline Rill 6 in watershed 1650 & 0.028 & 0.018 & 7 & $\begin{array}{l}\text { Measured detailed cross sections using an ero- } \\
\text { sion bridge on a northwest-facing hillslope. }\end{array}$ \\
\hline Rill field in watershed 1300 & 0.014 & 0.010 & 64 & $\begin{array}{l}\text { Several depths were measured across each rill } \\
\text { along transects spaced } 5 \mathrm{~m} \text { apart down a } \\
\text { northwest-facing hillslope. }\end{array}$ \\
\hline Rill field in watershed 2424 & 0.020 & 0.022 & 182 & $\begin{array}{l}\text { Depth, top width, and bottom width were } \\
\text { measured along } 12 \text { transects down a north- } \\
\text { east-facing hillslope (data provided by K. } \\
\text { Vincent). }\end{array}$ \\
\hline North mean & 0.022 & & 349 & \\
\hline
\end{tabular}




\section{Section 5--CHANNELS}

\section{Methods}

\section{Main Channel}

Changes in the volume of stored sediment by erosion and deposition in the main channels of Buffalo and Spring Creeks were measured from 1996 through 2000 by using aerial photogrammetry and ground surveys. Photogrammetry was used to determine cross-sectional profiles from stereo photographs taken in June 1996 (Appendix 3) after the wildfire but before the flood on 12 July 1996, and it was used to determine cross-sectional profiles from stereo photographs taken during August 1996 after the flooding. Later, a series of closely spaced channel crosssections in the study reach near the mouth of each watershed was surveyed repeatedly between June 1997 and October 2000 . Valley widths were typically $25-35 \mathrm{~m}$, so the surveyed cross sections were initially spaced $10 \mathrm{~m}$ apart to measure the volume within each study reach. Each study reach started at the mouth and extended upstream to the stream gage. The study reach in Buffalo Creek was 480 $\mathrm{m}$ long, and in Spring Creek 1,490 m long (fig. 5.1 and 5.2). Some cross sections were designated as permanent sections. At these sections, reference pins (4-foot, 1/2-inch rebar) were driven part way into the ground (with 0.10 to $0.30 \mathrm{~m}$ sticking above the ground) at each end of the cross section. Other cross sections were designated as transects for calculating volume and were marked by $8-\mathrm{cm} \times 8-\mathrm{cm}$ yellow plastic flagging on stiff $30-\mathrm{cm}$ long wire. Changes in volume at several adjacent cross sections or transects were very similar during 1997; in 1998, 1999, and 2000 the distance between cross sections was increased to approximately $30 \mathrm{~m}$.

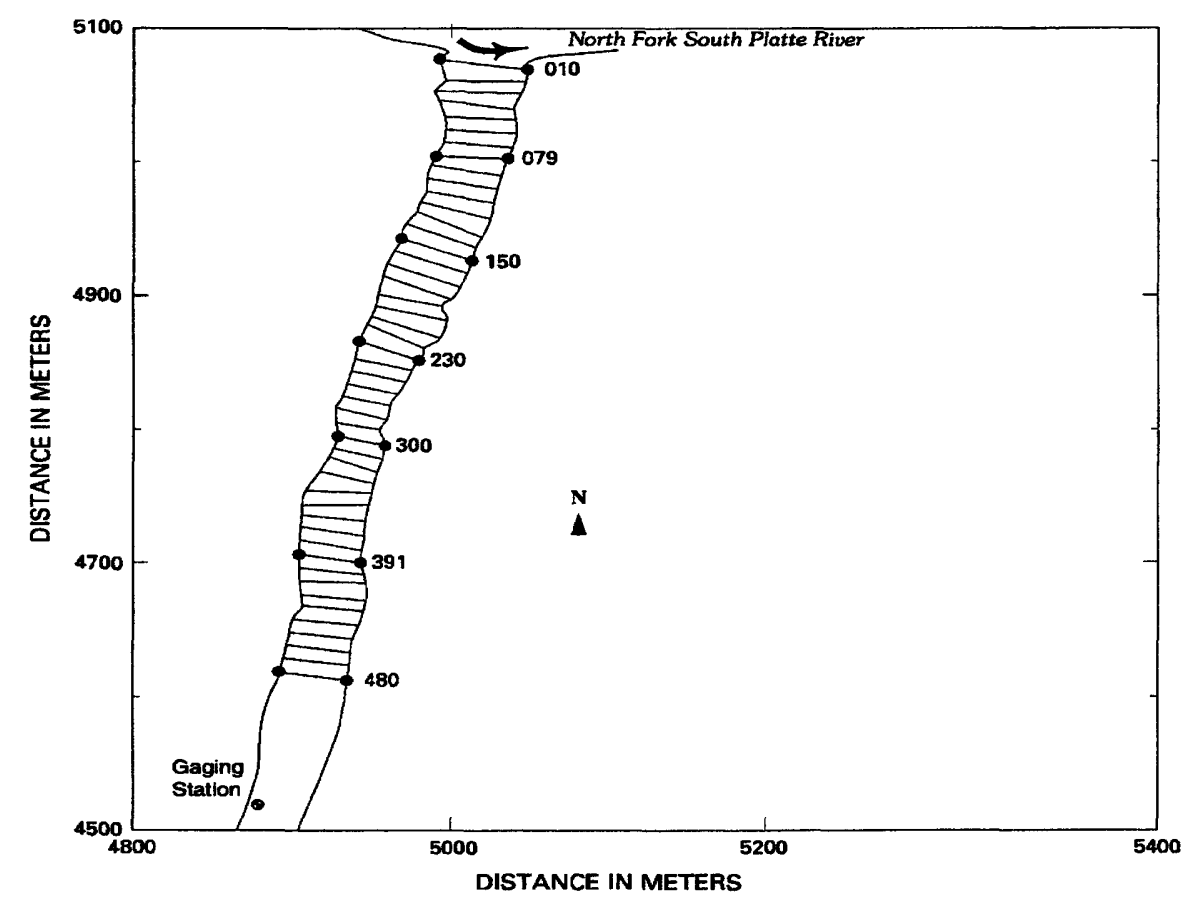

Figure 5.1. Buffalo Creek study reach. The arbitrary coordinates are shown across the bottom and along the left side. These coordinates closely approximate a true northsouth, east-west coordinate system. Cross-section numbers correspond to distance upstream from the mouth of Buffalo Creek. 


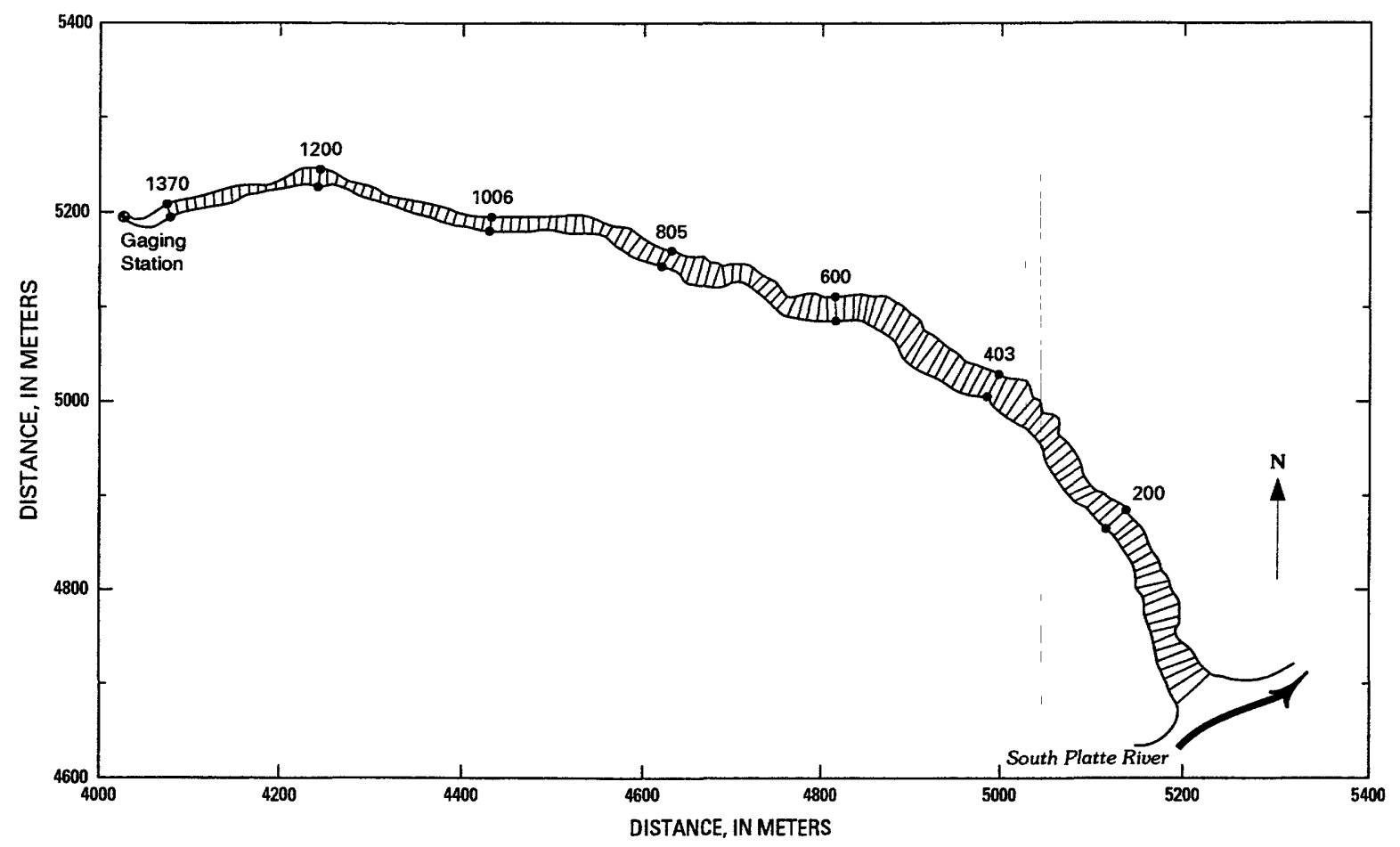

Figure 5.2. Spring Creek study reach. The arbitrary coordinates are shown across the bottom and along the left side. These coordinates closely approximate a true northsouth, east-west coordinate system. Cross-section numbers correspond to distance upstream from the mouth of Spring Creek.

Initially in 1997, the relative location and elevation of each cross section and transect were measured with an electronic surveying instrument (Nikon 720 DTM), but in the following years, they were remeasured with an automatic level, metric tape, and surveying rod. The coordinate system was arbitrary but chosen to closely approximate actual geographic orientation (true east and north, and elevation above sea level). The average location of reference pins, marking the ends of the cross sections, was determined after four surveys in 1997. The adjustments required to correct each survey to the average coordinate system were calculated and listed in Appendices 4 and 5. In Spring Creek, a GPS (Global Positioning System) survey grade system (Trimble 4700 Rover and 4800 Base) was used to determine the UTM (Universal Transverse Mercator) coordinates of selected reference pins (Appendix 6). This provided data to transform the arbitrary coordinate system $(E, N$, and $Z)$ to the UTM coordinate system $\left(E^{\prime}, N^{\prime}\right.$, and $\left.Z^{\prime}\right)$ using the following equations:

$$
\begin{gathered}
E=f(E \cos \theta-N \sin w \theta+d) \\
N^{\prime}=f(E \sin \theta+N \cos \theta+e), \\
Z=Z-z,
\end{gathered}
$$

where the scale factor, $f=0.9992$, the rotation angle, $\theta=2.67^{\circ}$, the east offset, $d=480763.458 \mathrm{~m}$, the north offset, $e=4358567.611 \mathrm{~m}$, and the elevation offset, $z=120.70 \mathrm{~m}$. These equations were used to compute the UTM coordinates for the reference pins in Spring Creek (Appendix 7). 
The UTM coordinates permitted the comparison of cross-sectional profiles measured in 1996 by photogrammetry with cross-sectional profiles measured in 1997 by ground survey. For both Buffalo and Spring Creek watersheds, all the cross section and transect data (listed in files on the accompanying $\mathrm{CD}$ ) are in the arbitrary coordinate system, and the format for the files is given in Appendices 8 and 9.

\section{Subwatersheds}

Erosion in drainages was measured in two Spring Creek subwatersheds (fig. 5.3) in 1999. One subwatershed, W960, is a south-facing, third-order (Strahler, 1952) watershed with an area of 7.0 ha. Its mouth is on the left bank $960 \mathrm{~m}$ upstream from the mouth of Spring Creek, and it has an estimated channel density of $21 \mathrm{~km} / \mathrm{km}^{2}$ after the fire. Watershed W1165 is a north-facing, fourth-order watershed with an area of $3.7 \mathrm{ha}$. It is on the right bank, $1,165 \mathrm{~m}$ upstream from the mouth of Spring Creek and has an estimated channel density of $48 \mathrm{~km} / \mathrm{km}^{2}$.

Drainages may be either unchannelized with no inflection point in a cross-sectional profile, or they may be channelized with at least two inflection points forming a bank. Estimates of drainage erosion included pre-fire channels and unchannelized drainages channelized by post-fire erosion. Cross-sectional erosion (volume of stored sediment lost per unit channel length or the cross-sectional area) was measured every $5 \mathrm{~m}$ along all drainages in these subwatersheds. The pre-flood land surface was estimated by extrapolating the post-flood land surface across the channel. This was aided in many places by using tree roots left exposed after the floods. These roots, in some cases, were unbroken and spanned the entire channel. Files of the basic data collected to calculate the erosion volumes are on the accompanying $\mathrm{CD}$ and the file formats are listed in Appendix 11. 

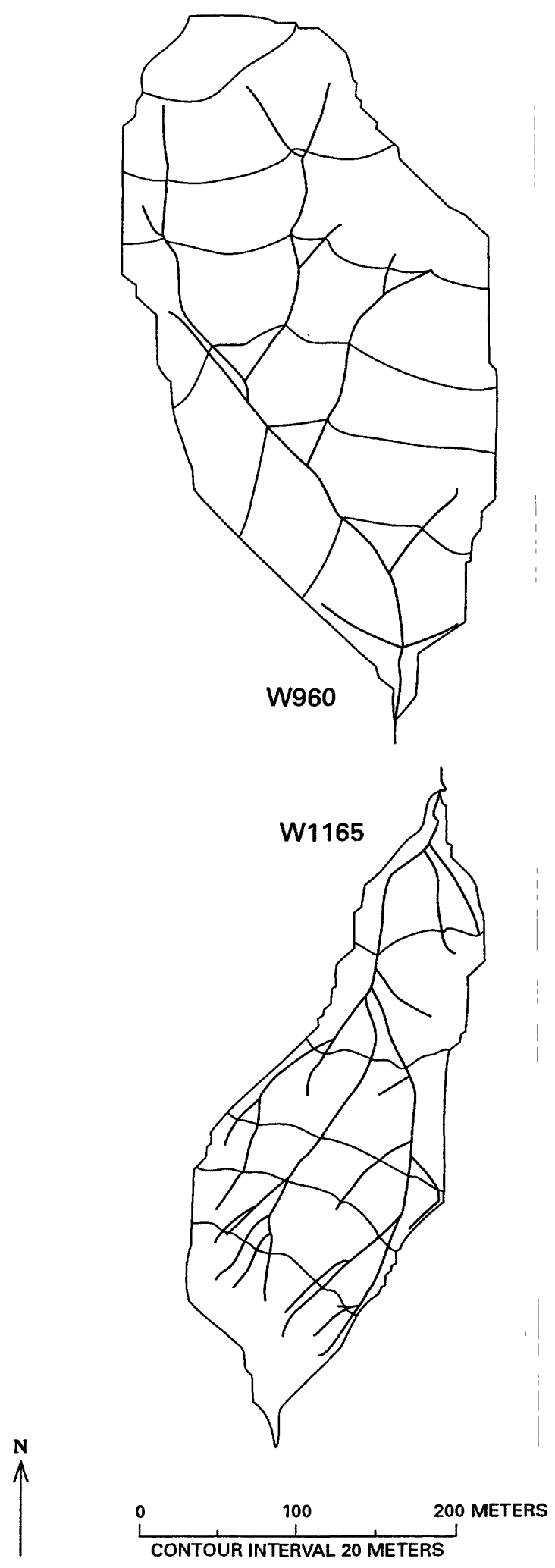

Figure 5.3. Subwatersheds in Spring Creek where drainage erosion was measured. Watershed 960 is a third-order watershed and watershed 1165 is a fourth-order watershed. 


\section{Results}

\section{Main Channel}

The primary erosional event was the thunderstorm on 12 July 1996, which was approximately a 100 -yr, 1-hour rainstorm based on maximum 30-minute rainfall intensities predicted by empirical equations developed from 6- and 24-hour precipitation data (Hershfield, 1961; Miller and others, 1973). In the Buffalo Creek watershed, sediment eroded from subwatersheds was deposited as alluvial fans at the mouth of each tributary. Sediment thickness decreased in the main channel downstream from each fan. Although the Buffalo Creek flood plain was buried near the mouth of each tributary, it was, in general, preserved throughout the length of the valley. However, the erosion and deposition in the main, east-west trending channel of Spring Creek was much different. Initial erosion occurred across the entire valley and removed any pre-existing flood plain. Alluvial fans were deposited at the mouths of tributaries and were connected to the channel sediment deposits, which were as thick as $4 \mathrm{~m}$. This deposition produced a sediment superslug (Nicholas and others, 1995) in Spring Creek occupying about 5,000 m along the main channel and extending across the entire valley.

Net erosion and net deposition for various time intervals between June 1996 and May 2000 were determined by calculating the difference in elevations at cross sections between successive surveys. Erosion and deposition following the flood on 12 July 1996 were determined by differencing 58 cross sections near the mouth of Spring Creek (Appendix 7). The elevations were determined by photogrammetry using stereo photographs taken on 2 June 1996 and 2 August 1996. This photogrammetric data had a resolution of about $\pm 0.1 \mathrm{~m}$ in both the vertical and horizontal direction. Erosion and deposition areas for a few cross sections are listed in table 5.1, and profiles for three cross sections at four different times are shown in figure 5.4. Depositional thickness varied throughout the study reach. For example, the maximum depositional thickness at section 187 was about $0.5 \mathrm{~m}$ where the valley is wide (fig. $5.5 \mathrm{~A}$ ). Where the valley is narrower at section 1200 , the maximum depth was about $2.0 \mathrm{~m}$. Similarly, the mean thickness would depend on the valley width so that the equivalent thickness at each cross section was calculated by dividing the area of erosion (negative) or deposition (positive) by the mean valley width ( $27 \mathrm{~m}$, fig. 5.5A). Thus, the equivalent thickness for the superslug created by the rainstorm increases downstream and reaches a maximum of $2.6 \mathrm{~m}$ at the mouth of Spring Creek (fig. 5.5B). The reach average equivalent thickness for the entire study reach was $0.54 \mathrm{~m}$. The cumulative thickness increased until 31 August 1997 and then remained approximately constant (table 5.2). Similar data for Buffalo Creek (table 5.3) indicate very little change in thickness within the study reach. Net erosion and deposition at each surveyed cross section in Spring Creek have been calculated for all time intervals between surveys (see selected cross sections in table 5.1 and Appendix 10). The equivalent thickness is plotted as a function of distance in figure 5.6 for successive time intervals.

No translational sediment wave was observed to propagate downstream, which in figure 5.6 would appear as a slug, or peak, moving from right to left (along the spatial axis) and from top to bottom (along the time axis). No diffusing stationary wave was evident. These results emphasize the unsteady nature of the sediment transport (Moody, 2001). This is probably a result of the unsteady character of the flow. In this case, prolonged periods of shallow flow over large relative roughness are suddenly interrupted by short periods of flash floods, in contrast to the steady character of perennial rivers. 

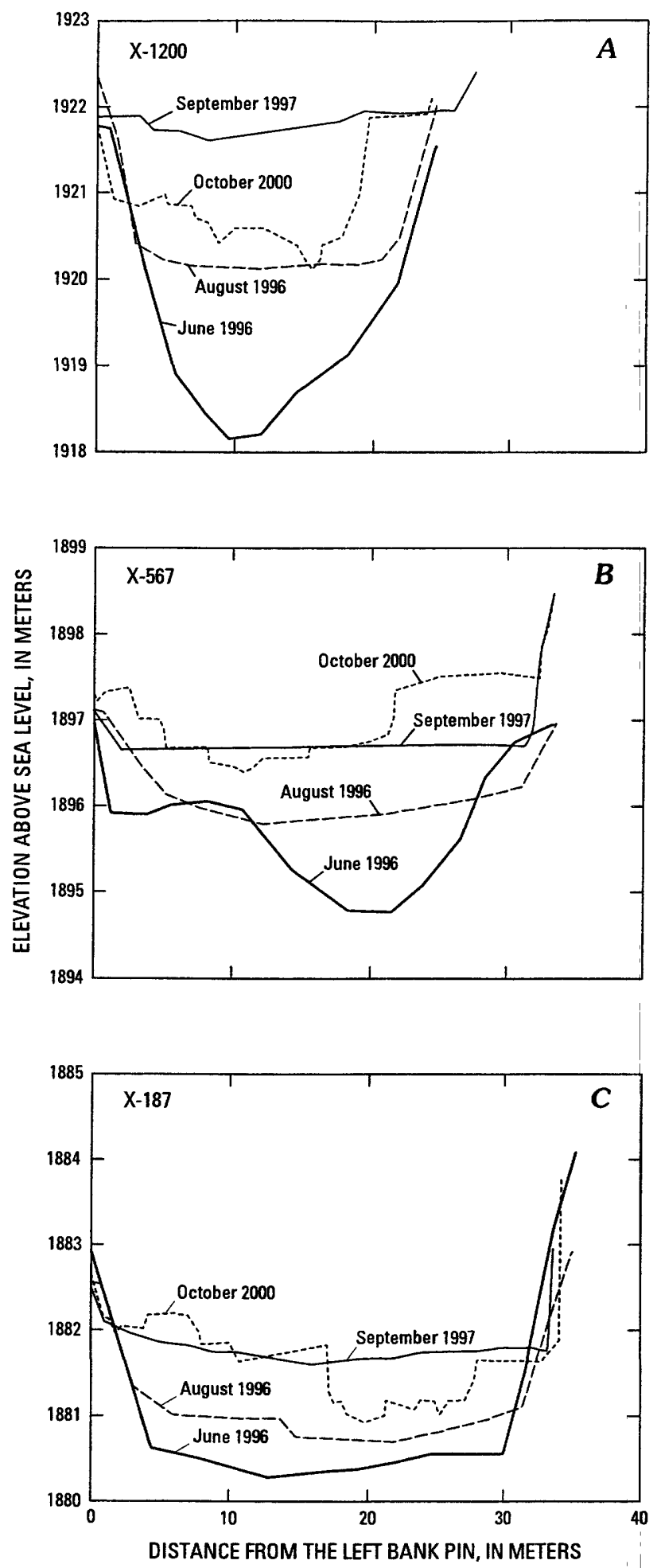

Figure 5.4. Three representative cross sections in Spring Creek. Profiles for June 1996 are based on photogrammetry and represent the morphology after the wildfire but before the erosion caused by intense rainstorms in June and July 1996. Profiles for August 1996 are based on photogrammetry and represent the morphology after the erosion caused by intense rainstorms and flooding in June and July 1996. Profiles for September 1997 are based on ground surveys and represent the morphology after the flash flood on 31 August 1997. Profiles for October 2000 are based on ground surveys and represent the morphology after a relatively long period with no significant flash floods. 

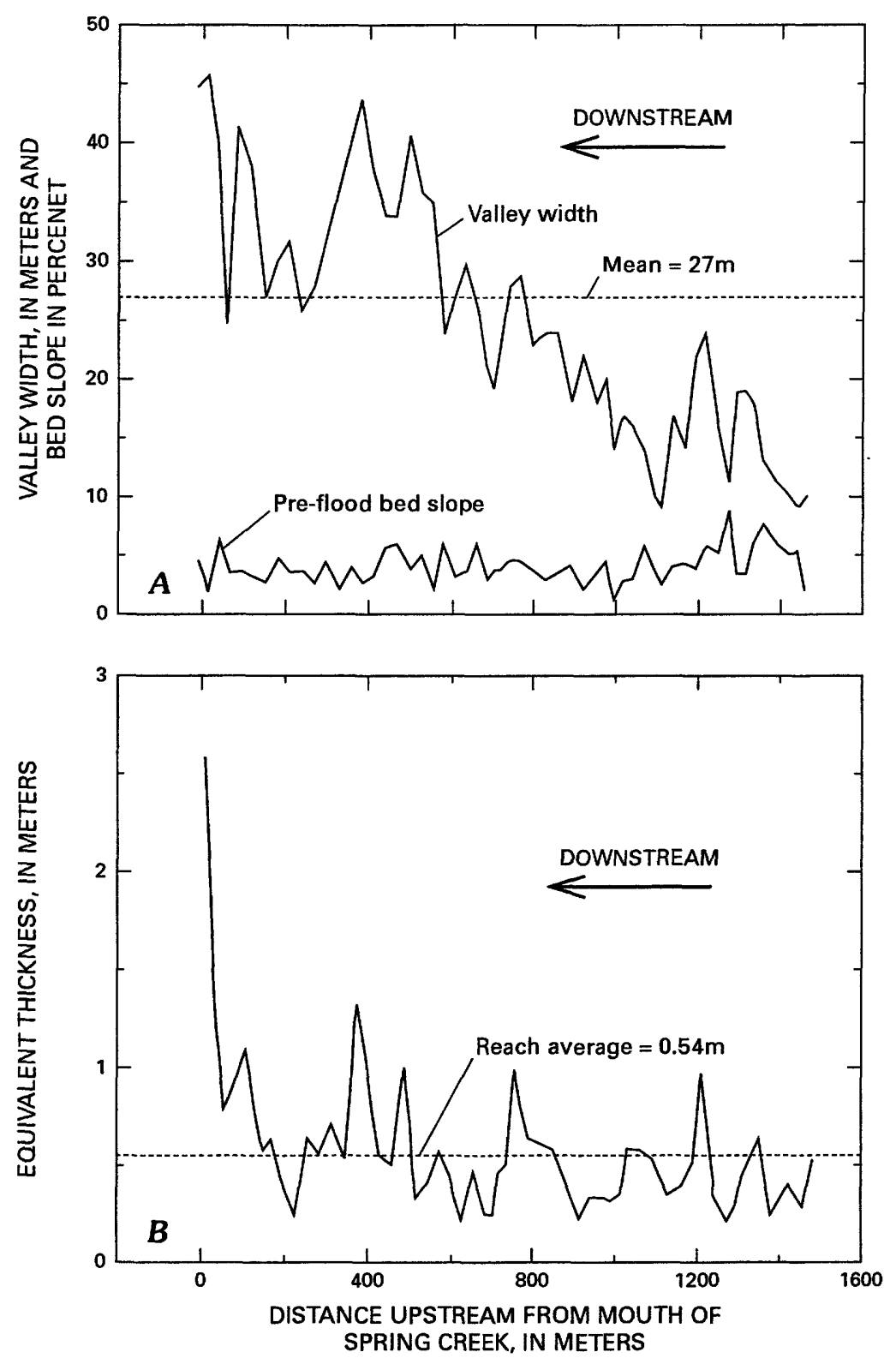

Figure 5.5. A. Variations in the valley width of Spring Creek and the pre-flood bed slope in June and July 1996. A. Valley width. The average valley width is $27 \mathrm{~m}$. B. The equivalent thickness of sediment deposited after the flooding in June and July 1996 and covering a width equal to the average valley width. 


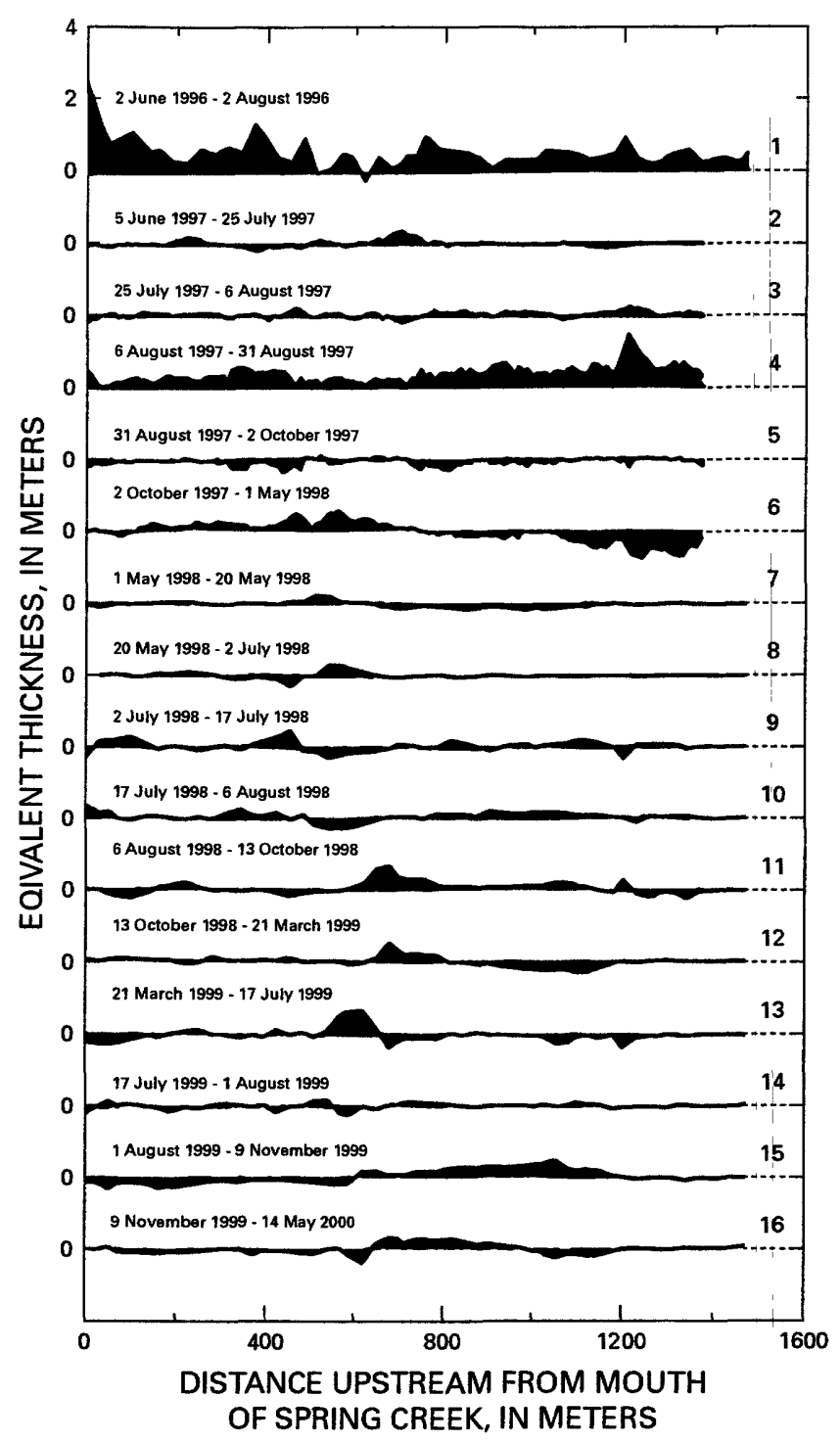

Figure 5.6. Changes in erosion (negative) and deposition (positive) as a function of time and distance upstream from the mouth of Spring Creek. Change is expressed as the equivalent thickness of sediment eroded or deposited between two successive surveys over a width equal to the average valley width $(27 \mathrm{~m})$. The same vertical scale is used for each time interval as shown for 2 June 1996 - 2 August 1996.

\section{Subwatersheds}

Erosion of unchannelized and channelized drainages after the 1996 wildfire was greater than deposition in the two subwatersheds (W960 and W1165) that were studied. The south-facing watershed (W960) had a net erosion of $1,800 \mathrm{~m}^{3}$, and the north-facing watershed (W1165) had net erosion of $470 \mathrm{~m}^{3}$ of sediment. Sediment erosion, however, was not spread evenly among the channels within the watershed. Some first-order channels often resembled rills in size. These first-order channels appear to be created by water discharged from a series of converging rills 
occupying a hollow (Welter, 1995) at the head of the first-order channel. From 7 to 9 percent of the eroded sediment came from first-order channels and 16 to 22 percent came from second-order channels (table 5.4). The majority (about 70 percent) of the eroded sediment came from thirdand fourth-order channels, similar to observations made in the Snowy Mountains of Australia (Brown, 1972). The average equivalent sediment yield (area weighted) from channels in these two subwatersheds was $210 \mathrm{~m}^{3} / \mathrm{ha}$.

One purpose for measuring these areas of erosion was to explore what possible topographic variables might be useful in predicting erosion on a watershed scale. Four possible variables were considered, contributing area, $A$; cumulative stream length upstream from the measurement location, $L$; local channel slope, $B$; side slope of the channel on both sides, $\phi_{1}$ and $\phi_{2}$; and the top width, $w$ (Appendix 11). Contributing area is a possible variable because water discharge, velocity, and shear stress in the channel depend on rainfall volume, which depends on contributing area. Cumulative stream length was considered as a possible surrogate for contributing area and has the advantage that it is easier to measure. Top width has the disadvantage in that it cannot be measured until after an erosional event, so measurements of erosion were regressed against contributing area and slope. Analysis indicated that the local slope had less effect on determining erosion than contributing area. Erosion in W960 was related to contributing area (fig. 5.7) and cumulative stream length (fig. 5.8) by

$$
\begin{array}{ll}
E=5.1 \times 10^{-4} A^{0.81} & r^{2}=0.73, \\
E=7.6 \times 10^{-3} L^{0.84} & r^{2}=0.72 .
\end{array}
$$

and the erosion in W1165 was given by

$$
\begin{aligned}
E & =7.7 \times 10^{-4} A^{0.66} & r^{2}=0.61 \\
E & =4.7 \times 10^{-3} L^{0.69} & r^{2}=0.66
\end{aligned}
$$

In addition, the top width was related to the cumulative stream length (fig. 5.9). For W960 the equation is:

$$
w=0.23 L^{0.41} \quad r^{2}=0.68
$$

and for W1165 it is:

$$
w=0.15 L^{0.39} \quad r^{2}=0.67
$$

These equations indicate that the cumulative stream length is a possible surrogate for contributing area as well as channel top width. Some of the variability of top width is probably caused by different side slopes of the channel. 


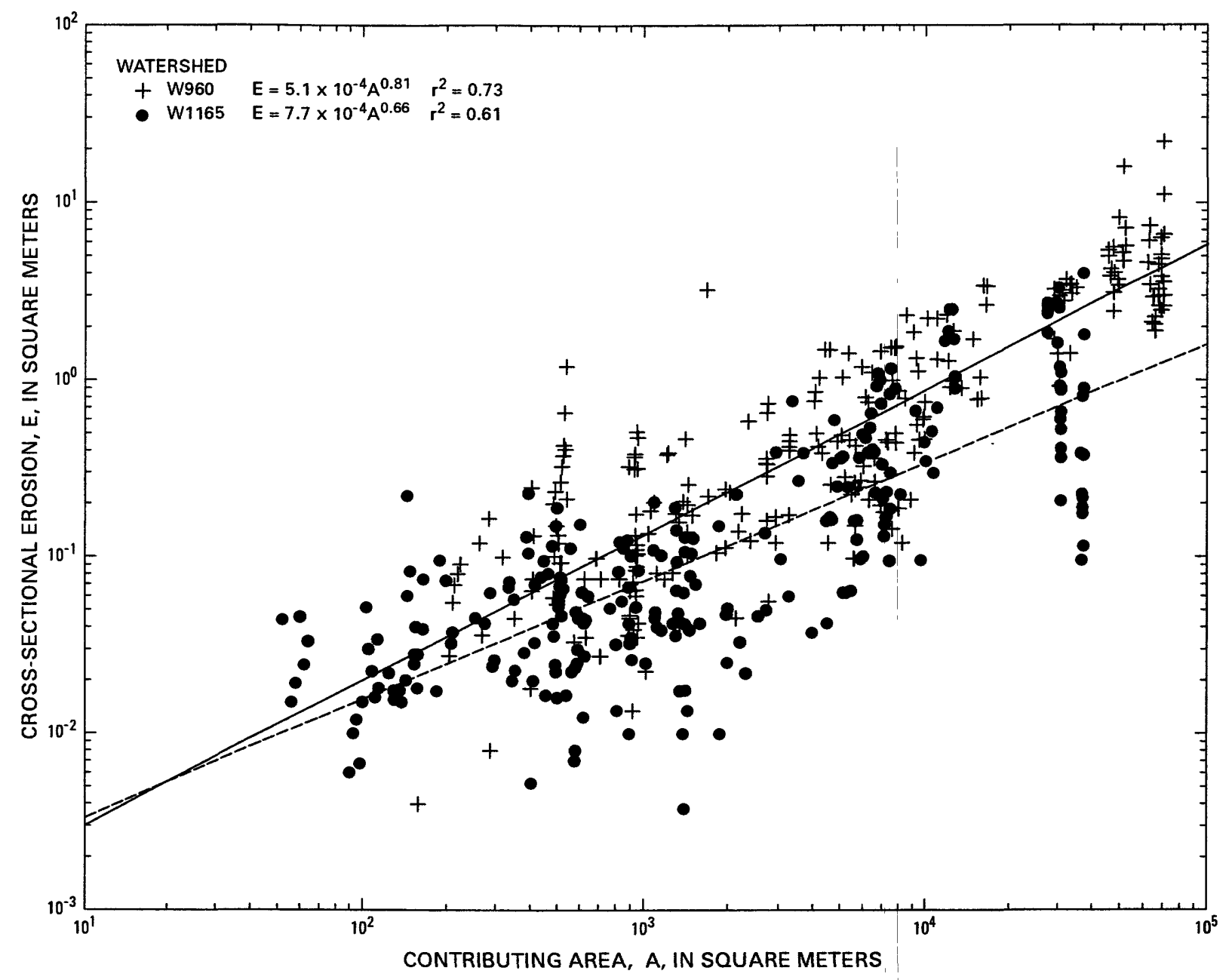

Figure 5.7. Erosion of sediment as a function of contributing area. Measurements were made at 5$\mathrm{m}$ intervals along all channels after the intense rainstorms in 1996 and 1997 . The dotted line represents W1165 and the solid line represents W960.

At present, contributing area or cumulative stream length can be used to provide initial estimates of the relative erosion. The differences in the relations for the south-facing watershed W960 (eqs. 5.4 and 5.5) and the north-facing watershed W1165 (eqs. 5.6 and 5.7) may indicate that the detachment properties of the soil types are different. If these soil properties were included more accurate erosional amounts might be predicted. Finally, the absolute erosional amounts will also depend upon the depth of rainfall for a given event and the subsequent depth of flow in the channels. It must be remembered that these data were collected after two large rainstorms (12 July 1996 and 31 August 1997) that were primarily erosional events in these relatively small subwatersheds. Smaller rainstorms were observed to produce both erosion and deposition in the subwatersheds. Therefore, including rainfall intensities and total amounts of precipitation should also improve the accuracy of the predictions. However, contributing area and cumulative stream length can be measured from a digital elevation model, unlike soil detachment and rainfall, and the empirical relations above can give initial estimates of the relative erosion for large rainstorms. 


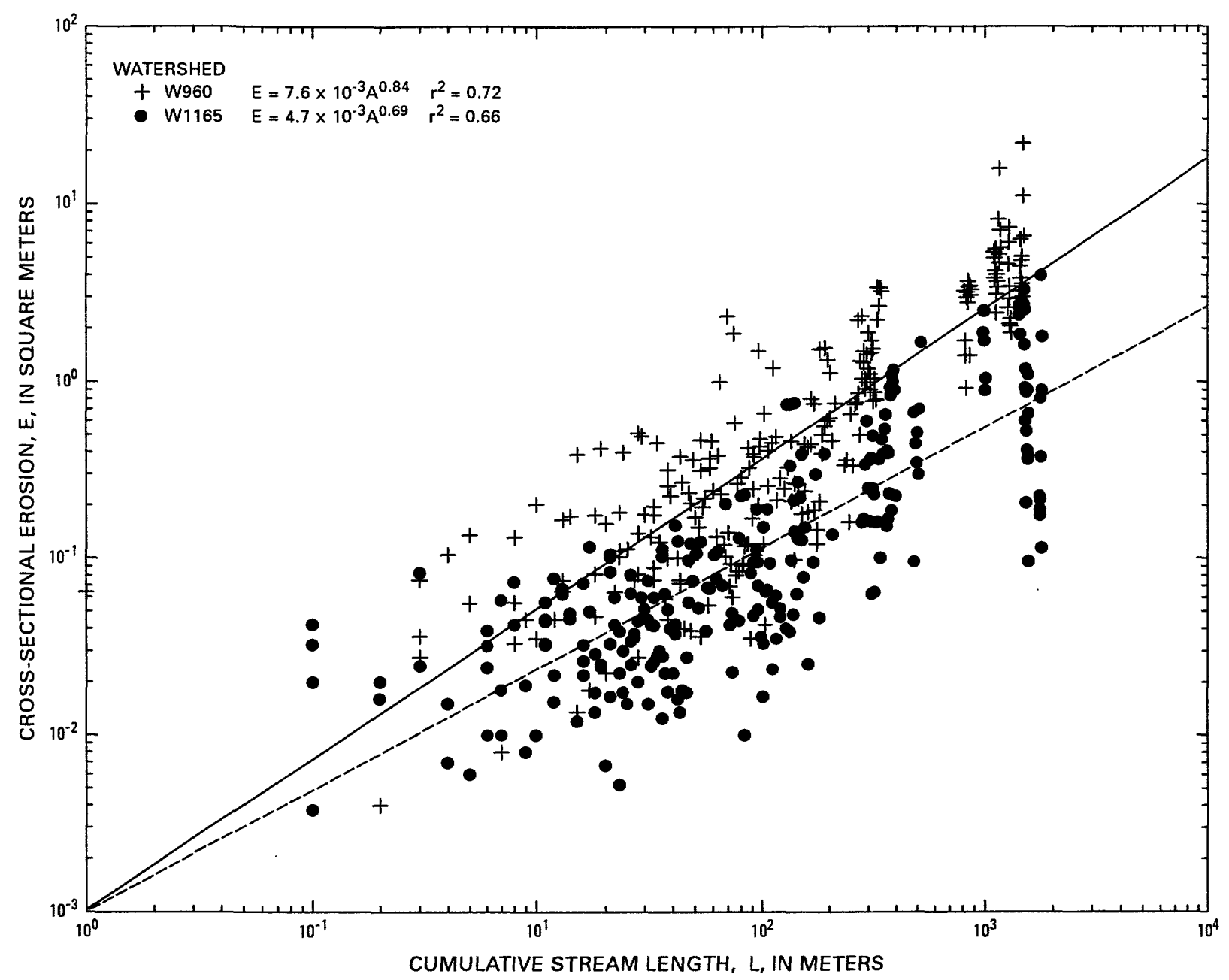

Figure 5.8. Erosion of sediment as a function of cumulative stream-length. Measurements were made at 5-m intervals along all channels in subwatersheds W960 and W1165 in the Spring Creek watershed after the intense rainstorms in 1996 and 1997. The dotted line represents W1165 and the solid line represents W960. 


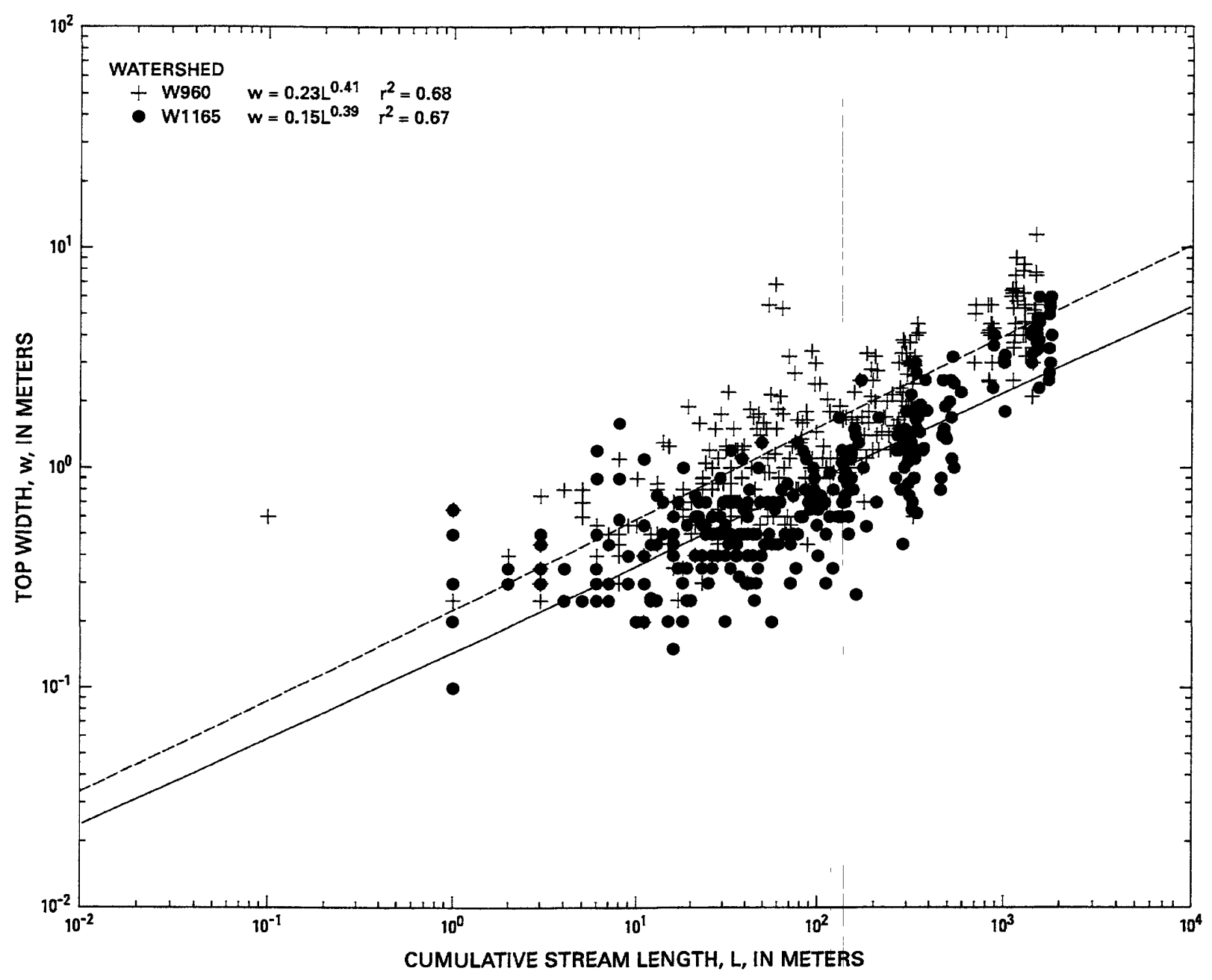

Figure 5.9. Relation between channel top-width and cumulative stream-length. Measurements were made at 5-m intervals along all channels in subwatersheds W960 and W1165 in the Spring Creek watershed after the intense rainstorms in 1996 and 1997. The dotted line represents W1165 and the solid line represents W960. 
Table 5.1. Erosion and deposition at selected channel cross-sections in the Spring Creek study area

[Numbers in table represent change in cross-sectional area in square meters $\left(\mathrm{m}^{2}\right)$; Eros.,net cross-sectional area of erosion; Dep., net cross-sectional area of deposition; ns, not surveyed]

\begin{tabular}{|c|c|c|c|c|c|c|c|c|c|c|c|c|c|c|c|c|c|c|}
\hline \multirow{3}{*}{ Dates } & \multicolumn{18}{|c|}{ Channel cross sections } \\
\hline & \multicolumn{2}{|c|}{-2.7} & \multicolumn{2}{|c|}{187} & \multicolumn{2}{|c|}{341} & \multicolumn{2}{|c|}{567} & \multicolumn{2}{|c|}{679} & \multicolumn{2}{|c|}{815} & \multicolumn{2}{|c|}{1006} & \multicolumn{2}{|c|}{1200} & \multicolumn{2}{|c|}{1450} \\
\hline & Eros. & Dep. & Sros. & Dep. & Eros. & Dep. & ros. & Dep. & Eros. & Dep. & Eros. & Dep. & Eros. & Dep. & Eros. & Dep. & Eros. & Dep. \\
\hline $\begin{array}{c}2 \text { June1996 } \\
2 \text { August } 1996\end{array}$ & 0.0 & 69.7 & 3.0 & 11.4 & 0.0 & 14.2 & 2.1 & 15.1 & 3.7 & 6.5 & 0.7 & 16.1 & 0.9 & 10.4 & 0.0 & 25.8 & 0.3 & 7.3 \\
\hline $\begin{array}{l}2 \text { August } 1996 \\
5 \text { June } 1997\end{array}$ & 15.5 & 14.9 & 0.0 & 13.9 & 0.4 & 4.0 & 1.6 & 3.6 & 0.1 & 6.5 & 2.1 & 1.2 & 0.0 & 8.4 & 1.2 & 0.9 & ns & ns \\
\hline $\begin{array}{l}5 \text { June } 1997 \\
\text { 25 July } 1997\end{array}$ & 1.1 & 0.0 & 0.7 & 1.4 & 2.6 & 0.1 & 1.4 & 0.8 & 0.4 & 7.2 & 0.4 & 0.3 & 0.8 & 0.5 & 2.2 & 0.4 & ns & ns \\
\hline $\begin{array}{l}25 \text { July } 1997 \\
6 \text { August } 1997\end{array}$ & 6.3 & 0.6 & 1.6 & 1.7 & 2.3 & 3.2 & 0.9 & 2.0 & 1.3 & 0.1 & 0.6 & 2.5 & 0.0 & 2.0 & 0.3 & 5.1 & ns & ns \\
\hline $\begin{array}{l}6 \text { August } 1997 \\
31 \text { August } 1997\end{array}$ & 5.9 & 19.9 & 1.0 & 9.0 & 0.3 & 15.6 & 1.0 & 8.8 & 0.4 & 6.6 & 1.1 & 11.3 & 0.2 & 11.0 & 0.2 & 30.5 & ns & ns \\
\hline $\begin{array}{l}31 \text { August } 1997 \\
2 \text { October } 1997\end{array}$ & 5.0 & 0.0 & 0.8 & 0.0 & 7.2 & 0.0 & 2.5 & 0.0 & 0.0 & 0.0 & 7.2 & 0.0 & 1.6 & 0.0 & 0.0 & 0.5 & ns & ns \\
\hline $\begin{array}{l}2 \text { October } 1997 \\
1 \text { May } 1998\end{array}$ & 1.6 & 1.0 & 0.7 & 2.1 & 1.6 & 6.2 & 0.1 & 14.4 & 0.1 & 3.8 & 1.5 & 0.4 & 1.3 & 0.1 & 10.1 & 3.0 & ns & ns \\
\hline $\begin{array}{c}1 \text { May } 1998 \\
20 \text { May } 1998\end{array}$ & 1.3 & 0.9 & 0.4 & 1.8 & 0.8 & 1.2 & 1.0 & 2.6 & 2.0 & 0.1 & 3.1 & 0.2 & 2.7 & 0.1 & 0.3 & 0.3 & 0.3 & 0.7 \\
\hline $\begin{array}{l}20 \text { May } 1998 \\
2 \text { July } 1998\end{array}$ & ns & ns & 0.6 & 1.7 & 0.6 & 1.6 & 0.0 & 7.4 & 1.5 & 0.0 & 1.7 & 0.3 & 0.4 & 0.1 & 0.4 & 0.5 & 0.6 & 0.3 \\
\hline $\begin{array}{l}\text { 2 July } 1998 \\
\text { 17 July } 1998\end{array}$ & $11.4^{\mathrm{a}}$ & $2.9^{\mathrm{a}}$ & 1.9 & 2.4 & 3.2 & 0.8 & 7.1 & 0.4 & 1.4 & 0.3 & 1.0 & 5.5 & 2.1 & 1.2 & 9.8 & 1.0 & 0.2 & 0.2 \\
\hline $\begin{array}{l}17 \text { July } 1998 \\
6 \text { August } 1998\end{array}$ & 2.7 & 12.0 & 0.8 & 0.8 & 0.4 & 7.0 & 8.5 & 1.3 & 1.3 & 2.5 & 0.3 & 2.6 & 0.1 & 4.7 & 2.5 & 3.0 & 0.3 & 0.4 \\
\hline $\begin{array}{l}6 \text { August } 1998 \\
13 \text { October } 1998\end{array}$ & 1.1 & 0.9 & 0.7 & 4.1 & 1.6 & 0.3 & 1.7 & 1.0 & 0.0 & 17.9 & 0.2 & 1.7 & 0.1 & 2.4 & 0.8 & 8.3 & 0.6 & 0.2 \\
\hline $\begin{array}{l}13 \text { October } 1998 \\
21 \text { March } 1999\end{array}$ & 1.4 & 2.2 & 1.8 & 2.5 & 0.8 & 0.7 & 1.3 & 1.3 & 0.0 & 13.6 & 2.9 & 1.4 & 6.1 & 0.1 & 0.2 & 0.2 & 0.4 & 0.4 \\
\hline $\begin{array}{l}21 \text { March } 1999 \\
17 \text { July } 1999\end{array}$ & 6.0 & 0.4 & 1.8 & 2.2 & 4.8 & 2.3 & 0.0 & 14.8 & 10.0 & 0.0 & 1.8 & 2.5 & 1.9 & 0.8 & 10.0 & 0.2 & 0.5 & 0.5 \\
\hline $\begin{array}{l}17 \text { July } 1999 \\
1 \text { August } 1999\end{array}$ & 6.5 & 1.0 & 4.5 & 0.2 & 1.1 & 1.6 & 5.4 & 0.0 & 0.9 & 1.8 & 0.9 & 1.9 & 1.3 & 0.6 & 2.7 & 1.7 & 0.3 & 0.3 \\
\hline $\begin{array}{l}1 \text { August } 1999 \\
8 \text { November } 1999\end{array}$ & 3.7 & 0.7 & 7.2 & 0.1 & 4.1 & 0.2 & 8.2 & 2.6 & 0.4 & 2.0 & 0.1 & 6.7 & 0.1 & 9.7 & 3.0 & 3.1 & 0.4 & 0.2 \\
\hline $\begin{array}{l}8 \text { November } 1999 \\
14 \text { May } 2000\end{array}$ & 1.2 & 0.6 & 2.4 & 0.2 & 1.2 & 0.9 & 0.9 & 1.4 & 0.0 & 8.3 & 0.1 & 7.2 & 2.5 & 0.1 & 0.7 & 0.3 & 0.1 & 1.3 \\
\hline $\begin{array}{l}14 \text { May } 2000 \\
21 \text { October } 2000\end{array}$ & 1.1 & 1.7 & 1.7 & 1.0 & 1.9 & 1.1 & 1.6 & 0.4 & 1.5 & 0.7 & 0.2 & 3.7 & 1.4 & 0.3 & 4.3 & 1.5 & 1.1 & 0.6 \\
\hline
\end{tabular}

${ }^{a}$ Change between 20 May 1998 and 17 July 1998. 
Table 5.2. Change in volume of sediment stored in the channel near the mouth of Spring Creek

[m, meter; $\mathrm{m}^{3}$, cubic meter; equivalent thickness, volume change divided by the product of the mean width (27 $\mathrm{m}$ ) and the length of the surveyed channel]

\begin{tabular}{|c|c|c|c|c|c|c|c|c|}
\hline \multicolumn{2}{|c|}{ Channel survey } & \multirow{2}{*}{$\begin{array}{l}\text { Elapsed } \\
\text { time } \\
\text { (days) }\end{array}$} & \multirow{2}{*}{$\begin{array}{l}\text { Number } \\
\text { of } \\
\text { cross } \\
\text { sections }\end{array}$} & \multirow{2}{*}{$\begin{array}{c}\text { Volume } \\
\text { change } \\
\Delta V \\
\left(\mathbf{m}^{3}\right)\end{array}$} & \multirow{2}{*}{$\begin{array}{l}\text { Length } \\
\text { of } \\
\text { surveyed } \\
\text { channel } \\
\text { (m) }\end{array}$} & \multirow{2}{*}{$\begin{array}{l}\text { Equiv- } \\
\text { alent } \\
\text { thickness } \\
\quad(\mathbf{m})\end{array}$} & \multirow{2}{*}{$\begin{array}{l}\text { Cumula- } \\
\text { tive } \\
\text { thickness } \\
\text { (m) }\end{array}$} & \multirow[b]{2}{*}{ Comments } \\
\hline Starting date & Ending date & & & & & & & \\
\hline 2 June 1996 & 2 August 1996 & 61 & 58 & 21,800 & 1,490 & 0.54 & 0.54 & $\begin{array}{l}\text { Volumes were based on photo- } \\
\text { grammetry method. }\end{array}$ \\
\hline 2 August 1996 & 5 June 1997 & 307 & 54 & 5,970 & 1,390 & 0.16 & 0.70 & $\begin{array}{l}\text { Volumes were based on photo- } \\
\text { grammetry and channel sur- } \\
\text { vey. }\end{array}$ \\
\hline 5 June 1997 & 25 July 1997 & 50 & 142 & 89.2 & 1,390 & 0.0024 & 0.70 & \\
\hline 25 July 1997 & 6 August 1997 & 12 & 142 & 1,260 & 1,390 & 0.034 & 0.73 & $\begin{array}{l}\text { Flash floods were on } 29 \text { and } 31 \\
\text { July } 1997 .\end{array}$ \\
\hline 6 August 1997 & 31 August 1997 & 25 & 142 & 17,720 & 1,390 & 0.47 & 1.20 & $\begin{array}{l}\text { Flash flood was on } 31 \text { August } \\
\text { and volume was } 14,920 \mathrm{~m}^{3} \text { in } \\
\text { the channel plus } 2,800 \mathrm{~m}^{3} \text { in } \\
\text { the South Platte River. }\end{array}$ \\
\hline 31 August 1997 & 2 October 1997 & 32 & 142 & $-2,920$ & 1,390 & -0.078 & 1.12 & \\
\hline 2 October 1997 & 1 May 1998 & 211 & 142 & $-1,330$ & 1,390 & -0.035 & 1.08 & $\begin{array}{l}\text { Estimated } 60 \text { days of active sed- } \\
\text { iment transport. }\end{array}$ \\
\hline 1 May 1998 & 20 May 1998 & 19 & 54 & -870 & 1,490 & -0.022 & 1.06 & \\
\hline 20 May 1998 & 2 July 1998 & 43 & 44 & -100 & 1,440 & -0.003 & 1.06 & \\
\hline 2 July 1998 & 17 July 1998 & 15 & 45 & 520 & 1,490 & 0.013 & 1.07 & Flash flood was on 9 July. \\
\hline 17 July 1998 & 6 August 1998 & 20 & 56 & 1,300 & 1,490 & 0.032 & 1.10 & Flash flood was on 31 July. \\
\hline 6 August 1998 & 13 October 1998 & 68 & 59 & 1,370 & 1,490 & 0.034 & 1.13 & \\
\hline 13 October 1998 & 21 March 1999 & 159 & 58 & -800 & 1,490 & -0.020 & 1.11 & \\
\hline 21 March 1999 & 17 July 1999 & 118 & 58 & -880 & 1,490 & -0.022 & 1.09 & \\
\hline 17 July 1999 & 1 August 1999 & 15 & 58 & -80 & 1,490 & -0.002 & 1.09 & $\begin{array}{l}\text { Flash flood was on } 29 \text { July and } \\
\text { eroded } 410 \mathrm{~m}^{3} \text { between the } \\
\text { mouth and section } 679 \\
\text { upstream from the mouth. It } \\
\text { deposited } 330 \mathrm{~m}^{3} \text { between } \\
\text { sections } 679 \text { and } 1470 .\end{array}$ \\
\hline 1 August 19998 & 8 November 1999 & 99 & 58 & 850 & 1,490 & 0.021 & 1.11 & \\
\hline 8 November 1999 & 14 May 2000 & 188 & 57 & -410 & 1,470 & -0.010 & 1.10 & \\
\hline 14 May 2000 & 21 October 2000 & 160 & 17 & -380 & 1,450 & -0.010 & 1.09 & \\
\hline
\end{tabular}


Table 5.3. Change in volume of sediment stored in the channel near the mouth of Buffalo Creek

$\left[\mathrm{m}\right.$, meter; $\mathrm{m}^{3}$, cubic meter; equivalent thickness $=$ volume change divided by the product of the mean width $(35$ $m)$ and the length of the surveyed channel]

\begin{tabular}{|c|c|c|c|c|c|c|c|c|}
\hline \multicolumn{2}{|c|}{ Channel survey } & \multirow{2}{*}{$\begin{array}{l}\text { Elapsed } \\
\text { time } \\
\text { (days) }\end{array}$} & \multirow{2}{*}{$\begin{array}{l}\text { Number } \\
\text { of } \\
\text { cross } \\
\text { sections }\end{array}$} & \multirow{2}{*}{$\begin{array}{c}\text { Volume } \\
\text { change } \\
\left(\mathbf{m}^{3}\right)\end{array}$} & \multirow{2}{*}{$\begin{array}{l}\text { Length } \\
\text { of } \\
\text { surveyed } \\
\text { channel } \\
\text { (m) }\end{array}$} & \multirow{2}{*}{$\begin{array}{l}\text { Equiv- } \\
\text { alent } \\
\text { thickness } \\
\text { (m) }\end{array}$} & \multirow{2}{*}{$\begin{array}{l}\text { Cumula- } \\
\text { tive } \\
\text { thickness } \\
\text { (m) }\end{array}$} & \multirow{2}{*}{ Comments } \\
\hline Starting date & Ending date & & & & & & & \\
\hline 14 June 1997 & 20 July 1997 & 36 & 48 & 1,120 & 470 & 0.068 & 0.068 & \\
\hline 20 July 1997 & 11 August 1997 & 22 & 48 & -25 & 470 & -0.002 & 0.066 & $\begin{array}{l}\text { Flash floods were on } 28,29 \\
\text { July and } 2 \text { August. }\end{array}$ \\
\hline 11 August 1997 & 8 May 1998 & 270 & 48 & 370 & 470 & 0.022 & 0.088 & $\begin{array}{l}\text { Flash floods were on } 26,31 \\
\text { August. }\end{array}$ \\
\hline 8 May 1998 & 21 July 1998 & 74 & 27 & $-3,680$ & 470 & -0.22 & -0.13 & $\begin{array}{l}\text { Average runoff was in May } \\
\left(1.68 \mathrm{~m}^{3} / \mathrm{s}\right) \text { which was } \\
\text { greater than the other } \\
\text { months in } 1998 .\end{array}$ \\
\hline 21 July 1998 & 7 August 1998 & 17 & 16 & 2,310 & 470 & 0.14 & 0.01 & Flash flood was on 31 July. \\
\hline 7 August 1998 & 17 October 1998 & 71 & 16 & 210 & 470 & 0.013 & 0.013 & \\
\hline
\end{tabular}


Table 5.4. Characteristics and erosion volumes for drainages in two subwatersheds in the Spring Creek watershed

[km, kilometer; $\mathrm{m}$, meter; $\mathrm{m}^{2}$, square meter; $\mathrm{m}^{3}$, cubic meter; $\%$, percent; Erosion measurements were made after two major rainstorms on 12 July 1996 and 31 August 1997; Watershed number refers to distance, in meters, upstream from the mouth of Spring Creek]

\begin{tabular}{|c|c|c|}
\hline Characteristic & Watershed 960 & Watershed 1165 \\
\hline General aspect & South facing & North facing \\
\hline Area (hectares) & 7.01 & 3.72 \\
\hline Percent of Spring Creek watershed & 0.26 & 0.14 \\
\hline Order & 3 & 4 \\
\hline Number of channel links & 20 & 37 \\
\hline Total stream length $(\mathrm{km})$ & 1.47 & 1.80 \\
\hline Stream density $\left(\mathrm{km} / \mathrm{km}^{2}\right)$ & 21 & 48 \\
\hline Overland flow length $=1 /(2 \times$ stream density $)(\mathrm{m})$ & 24 & 10 \\
\hline \multicolumn{3}{|l|}{ Critical area for channel initiation } \\
\hline minimum area $\left(\mathrm{m}^{2}\right)$ & 63 & 51 \\
\hline average area $\left(\mathrm{m}^{2}\right) \pm$ standard deviation & $400 \pm 330$ & $230 \pm 230$ \\
\hline Total net erosion volume $\left(\mathrm{m}^{3}\right)$ & 1800 & 470 \\
\hline 1 st-order channels (\%) & 7 & 9 \\
\hline 2nd-order channels $(\%)$ & 22 & 16 \\
\hline 3rd-order channels (\%) & 71 & 18 \\
\hline 4th-order channels (\%) & none & 57 \\
\hline Sediment Yield (m3/hectare) & 257 & 126 \\
\hline
\end{tabular}




\section{Section 6-SEDIMENT TRANSPORT}

\section{Methods}

\section{Bed Material}

The character of the bed material in Buffalo and Spring Creeks was determined from surficial samples collected near the mouth of two tributaries to Buffalo Creek, and from samples collected at or near the mouth of Buffalo and Spring Creeks (table 6.1). Eight surficial samples were collected in Spring Creek along the main channel to determine the downstream variation in grain sizes of the sediment deposited after the floods in 1996 and 1997 (table 6.2). Particle-size distributions were determined by sieving all sediment samples using a RoTap equipment for 15-20 minutes, weighing, and reporting by whole phi sizes (Guy, 1969). The Cory shape factor is given by:

$$
S_{c}=\frac{\gamma}{\sqrt{\alpha \beta}}
$$

where $\alpha, \beta$, and $\gamma$ are diameters of a particle from smallest to largest axes. This was measured for one size class of sediment diameters from Spring Creek $(11.3-16 \mathrm{~mm})$.

\section{Direct Measurements}

A sediment rating curve was established for the mouth of each watershed by collecting bed-load and suspended-load samples and by measuring the water discharge at selected times over a four-year period (1997-2000). Additionally, estimates of the total sediment transport rates were made for high flows for selected flash floods based on indirect measurements discussed as follows: For low flows, bed load was collected during steady-flow conditions using a modified Helly-Smith bed-load sampler (Emmett, 1980; Hubbell and others, 1986) referred to as the US BLH-84 (fig. 6.1A) (Druffel and others, 1976; U.S. Geological Survey, 1990; Ryan and Porth, 1999). This was made from 1-mm thick, stainless-steel sheet metal so that the predominant sandand gravel-size particles would not accumulate at the lip of the sampler and, thus, underestimate the bed load. It had the standard 76.2-mm-square opening but was made with the 1.40 expansion ratio nozzle to eliminate backwater effects from using the sampler in the relatively narrow channels (1-2 m). A $0.250-\mathrm{mm}$, nylon-mesh net was attached to the US BLH-84 sampler. Four replicates (grain size $>0.250 \mathrm{~mm}$ ) were collected each time the bed load was sampled. These replicates were dried at $105^{\circ} \mathrm{C}$ and sieved (using a RoTap for 15-20 minutes) by whole phi intervals ( $\Phi=\log _{2} D$, where $D$ is the particle diameter in millimeters, Krumbein, 1934). The resultant data are listed in tables 6.3 and 6.4 .

Suspended load was collected between each bed-load replicate using a $450-\mathrm{mL}$ pint jar fitted with a cap and a 3-mm-diameter isokinetic nozzle (fig. 6.1B) (Edwards and Glysson, 1988; Meade and Stevens, 1990). The suspended sediment was wet sieved by whole phi intervals, filtered through preweighted Millipore HA filters $\left(0.45\right.$-micron pore size), dried at $105^{\circ} \mathrm{C}$, and weighed to within $0.01 \mathrm{mg}$. The preweighed mass of the filter was subtracted to obtain the mass of sediment. 

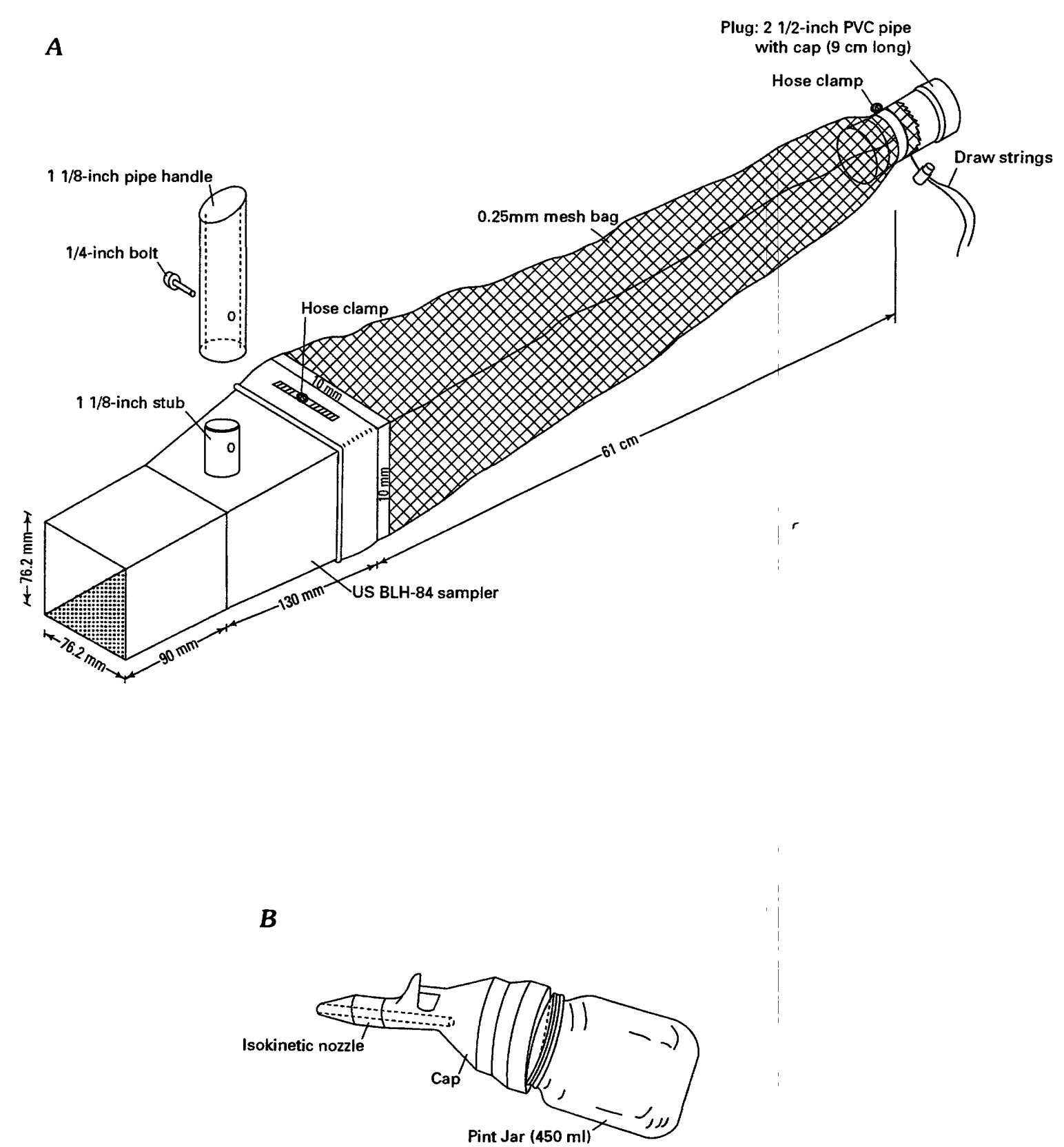

Figure 6.1. Sediment samplers. A. Bed-load sampler US BLH-84. Sediment is removed from the mesh bag by loosening the hose clamp at the end with the plug and removing the plug. Clear water can be poured through the sampler to wash out the sediment.

B. Suspended sampler with an isokinetic nozzle.

Because the mesh size of the bed-load sampler was less than the diameter of the isokinetic nozzle, the bed-load sample contained some suspended load. The diameter, $D^{*}$, of a particle with a fall velocity equal to the shear velocity, $u^{*}$, was used to separate the suspended load from the bed load for each sample. Shear velocity is given by

$$
u^{*}=\sqrt{g h S},
$$


where $g$ is the acceleration of gravity, $h$ is the mean depth, and $S$ is the water surface slope. Adjusted bed loads and suspended loads are listed in tables 6.5 and 6.6. One discharge measurement was made between replicates 2 and 3 using a Price AA current meter or surface floats if the water depth was too shallow for the current meter (tables 3.1, 3.2, 6.3, and 6.4).

\section{Thresholds of Motion}

Critical shear stress for the largest particles moving as bed load and the settling velocity for the largest particles in suspension were determined for sediment samples collected in Buffalo and Spring Creeks. The median diameter, $D_{b}$, of the largest size-class ( $\leq 5$ percent of the total sample) in the US BLH-84 sampler was assumed to represent the particles just beginning to move as bed load. Because bed forms and bars were not present during sample collection the form drag was assumed to be zero, and thus, the critical shear stress for the initiation of motion was set equal to the total bed shear stress measured during the sample collection (tables 6.7 and 6.8). The settling velocity of the maximum particle size in suspension, $D_{s}$, was calculated by using the fourthorder polynomial equation given by Dietrich (1982), with a sediment density, $\rho_{s}=2,650 \mathrm{~kg} / \mathrm{m}^{3}$, and a kinematic viscosity, $v=0.0116 \mathrm{~cm}^{2} / \mathrm{s}$ for $15^{\circ} \mathrm{C}$.

\section{Indirect Measurements}

Indirect measurements were used to determine sediment volume and discharge during flash floods when it was too dangerous to sample sediment or to measure water discharge directly. Sediment volumes transported by these flash floods were deposited in the Spring Creek study reach. This reach expands from $8 \mathrm{~m}$ wide at the upper end near the gage to $60 \mathrm{~m}$ wide at the mouth and acts as a sediment trap. The flood hydrograph was modeled using a linear reservoir model (Nash, 1958) with $\mathrm{n}=3$ and $\mathrm{K}$ ranging from 3.5-10.5 minutes. The predicted hydrograph was constrained by the measured peak discharge and the restriction that the total mass or volume of water must be conserved at the Spring Creek gage site. The South Platte gage site operated by the state of Colorado on the South Platte River at South Platte, Colorado, served as the alternate gage if the Spring Creek gage malfunctioned. Time-averaged discharge was the volume of water divided by the duration of the flash flood. Time-averaged depth (column 2, table 6.9) was then determined from the time-averaged discharge and the critical-flow model applied at the Spring Creek gage site using the measured geometry of the site (table 3.5). The change in the sediment volumes was calculated from the channel surveys (described in section 5) for seven flash floods (table 6.9) and divided by the duration of the flash flood (table 6.9) to estimate the total sediment discharge during a flash flood (table 6.9). Maximum particle sizes, $D_{b}$ and $D_{s}$ (table 6.9), moving as bed load and in suspension, were used with the bed material particle-size distribution for Spring Creek (table 6.1, fig. 6.2, and Appendix 12) to determine the proportion of the bed material moving as bed load and as suspended load (table 6.9). These sediment discharges were certainly a minimum estimate, as some sediment was transported down the South Platte River; however, field observations indicate this was probably much smaller than the volume of sediment deposited in the study reach. Peak discharges were determined by high-water marks and the slope-area method (Dalrymple and Benson, 1967). Buffalo Creek was not modeled by this method because most of the volume was transported directly into the North Fork of the South Platte River and very little was stored within the study reach. 


\section{$\underline{\text { Results }}$}

\section{Bed Material}

Bed material deposited in Buffalo Creek, after the fire and erosional events in 1996, was finer than in Spring Creek. The predominant size class was 2-4 mm in Buffalo Creek and 4-8 $\mathrm{mm}$ in Spring Creek (table 6.1, fig. 6.2). Spring Creek had a definite bimodal distribution that was the result of larger cobbles and boulders being sapped from the granite outcrops along the channel sides. These formed boulder bars in the main channel of Spring Creek that occupied about 8 percent of the surface area as viewed on aerial photographs. The bed material was the Pikes Peak granite, which typically weathers into grüs with roughly cubical shapes as illustrated by the Cory shape factor. The distribution of shape factors for one size class (11.3 to $16 \mathrm{~mm})$ was approximately normal (fig. 6.3$)$, with the mean $(0.67 \mathrm{~mm})$ almost equal to the median value $(0.66 \mathrm{~mm})$.

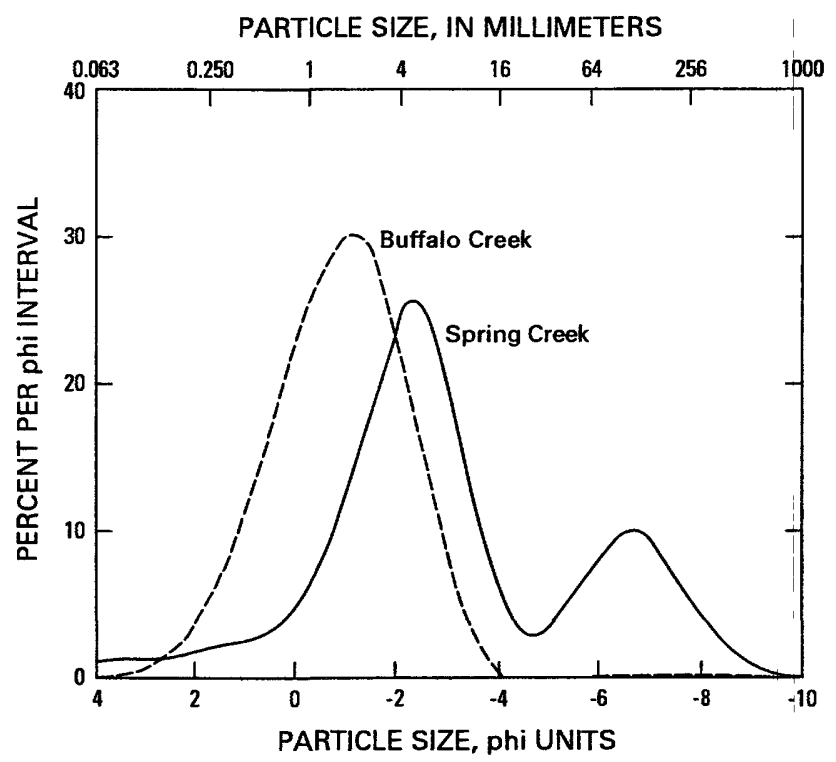

Figure 6.2. Comparison of the particle-size distribution of bed material in Buffalo and Spring Creeks. The second peak on the Spring Creek curve represents large particles sapped from the exposed bedrock along the sides of the channels.

The median size $\left(\mathrm{D}_{50}\right)$ of the surficial bed material in Spring Creek increases from the headwaters to the mouth. The median size was 1.3 and $1.5 \mathrm{~mm}$ in two headwater tributaries (6,260 m upstream from the mouth), and the median size increased to $4.3 \mathrm{~mm}$ at the mouth (table 6.2). The degree of sorting indicated by $\sigma$ is essentially constant $(3.0 \pm 0.3)$ but is relatively large, which indicates a wide range of sizes. Downstream fining of sediment is generally the rule and has been attributed to abrasion (Shaw and Kellerhals, 1982), selective transport of finer grains (Paola and Seal, 1995), and finer input by tributaries downstream (Pizzuto, 1995). The material in this system has mixed grain sizes, shapes that roll easily, and the relative roughness (bed particle diameters divided by water depth) is much greater than the relative roughness in perennial rivers, where most sediment transport theory has been developed. Particle-size analysis of bed-load measurements discussed below indicate that larger particles are preferentially transported in this system, which could explain the downstream coarsening of bed material. 


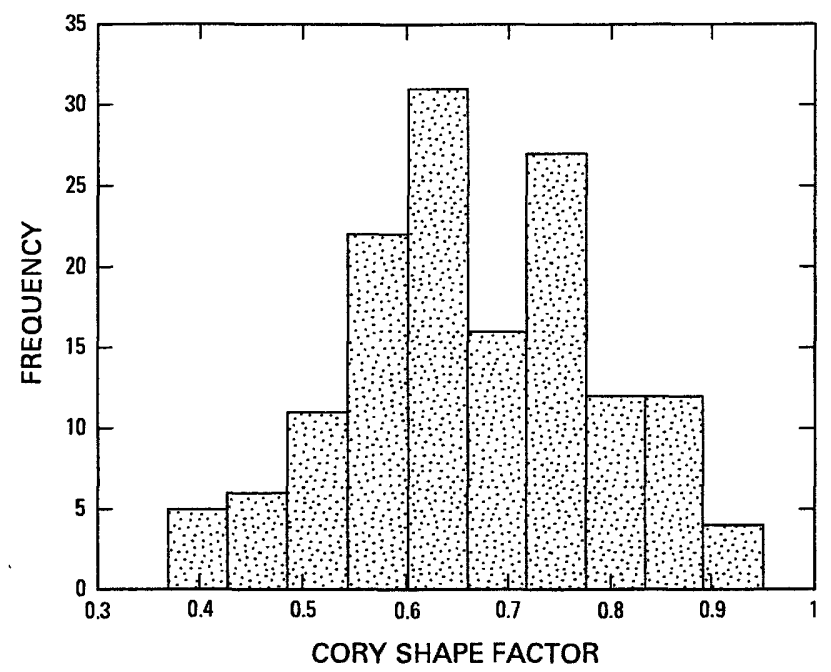

Figure 6.3. Distribution of particle shapes for the 11.3-16.0 mm size class of bed load in Spring Creek. Cory shape factor is defined in the text.

\section{Total Load Rating Curves}

Sediment transport rates increased after the wildfire. Total transport rates (bed load and suspended load) were available for Buffalo Creek before the wildfire (fig. 6.4) but not for Spring Creek. After the wildfire, the measured total transport rate (table 6.6) in Buffalo Creek indicated about a 60 -fold increase at $0.5 \mathrm{~m}^{3} / \mathrm{s}$, and a 20 -fold increase at $1.0 \mathrm{~m}^{3} / \mathrm{s} \mathrm{(fig.} \mathrm{6.4).} \mathrm{Without} \mathrm{pre-fire}$ data for Spring Creek, the absolute increase is unknown, but the total sediment transport rate in Spring Creek (tables 6.5 and 6.9) after the wildfire was about 5-10 times the post-fire transport rate in Buffalo Creek. Regression equations for total sediment transport rate, $Q_{s}$, and water discharge, $Q_{w}$, in Buffalo and Spring Creeks are

$$
\begin{gathered}
Q_{s}=23 Q_{w}^{1.5}, r^{2}=0.89 \\
Q_{s}=23 Q_{w}^{1.3}, \quad r^{2}=0.96
\end{gathered}
$$

The outliers for the Buffalo Creek sediment-rating curve (shown as solid circles in fig. 6.4) are measurements made after most of the sediment in the channel had been evacuated in July 1998 and May 2000 and the channel resembled pre-fire conditions. These outliers agree with the set of pre-fire, total-load measurements made in 1985 in Buffalo Creek ( + symbols in fig. 6.4) when the

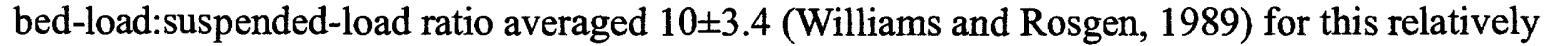
clear mountain trout stream. After the fire in Buffalo Creek, the bed-load:suspended-load ratio was less and averaged 6.1 \pm 2.8 indicating that much more fine material was available for transport. For Spring Creek, the ratio was greater and more variable (14 \pm 16$)$.

Bed-load transport rates $(\mathrm{kg} / \mathrm{s})$, when normalized by water discharges (expressed as mass, $\mathrm{kg} / \mathrm{s}$, rather than as a volume, $\mathrm{m}^{3} / \mathrm{s}$ ), give a dimensionless sediment transport efficiency. The effi- 


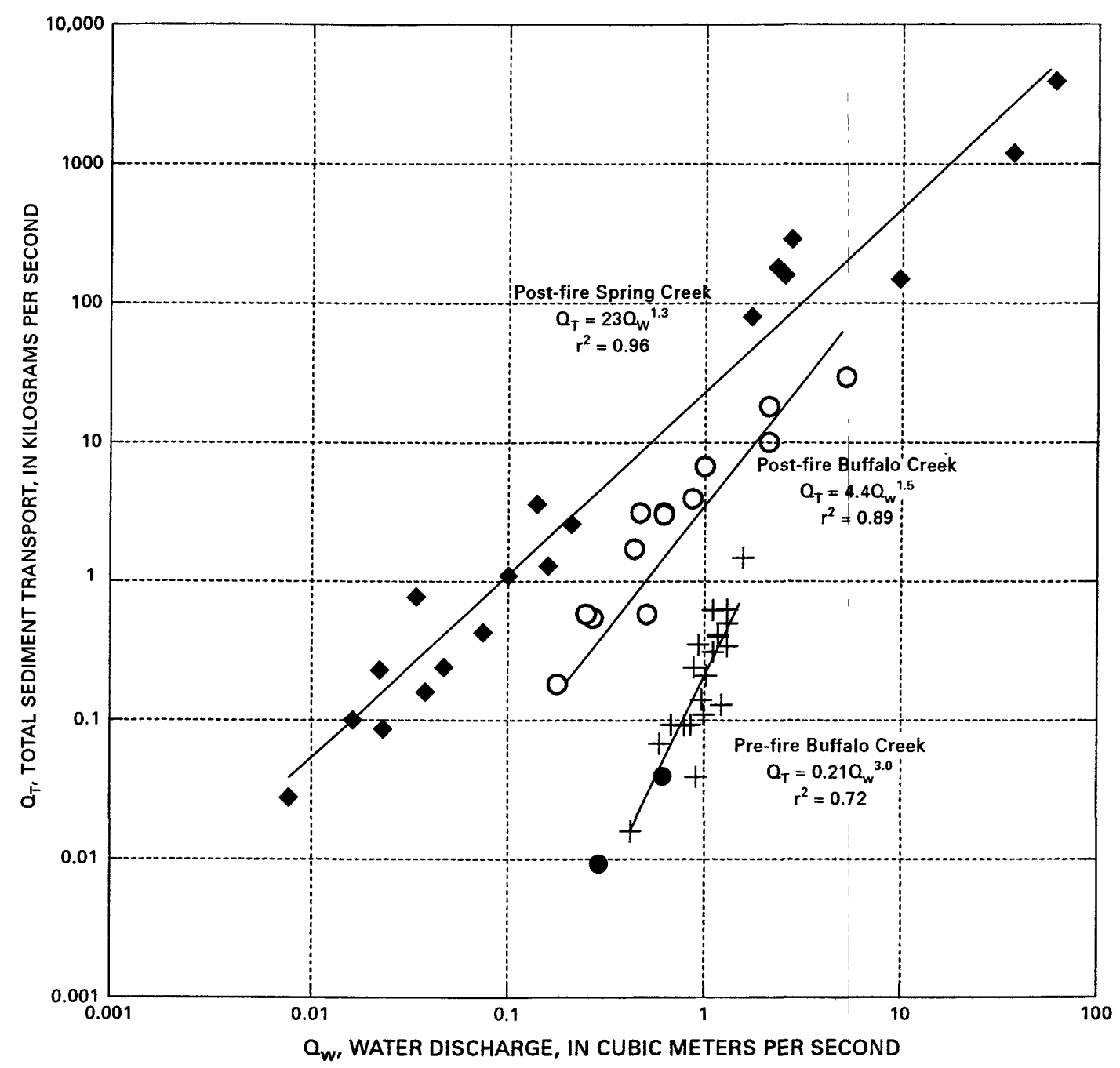

Figure 6.4. Total sediment transport as a function of water discharge in Buffalo and Spring Creeks. The two solid circles represent samples collected in Buffalo Creek after the wildfire when the channel had been flushed of the sand and fine gravel.

ciency of bed-load transport for these two streams increased after the wildfire, in response to the increased sediment supply. Many rivers, ranging in size from the low-gradient Amazon to highgradient mountain streams, generally have efficiencies in the range of 0.0001 to 0.1 percent and are usually slope limited in the case of the Amazon or supply limited in the case of mountain streams (table 6.10). Spring Creek had efficiencies that ranged from 0.34 to 2.3 percent after the wildfire, while in Buffalo Creek they ranged from 0.0019 to 0.76 percent, which represented an approximate 10 -fold increase from pre-fire efficiencies. Relatively high efficiencies $(0.0077$ to 0.17 percent, based on data reported by Williams and Rosgen, 1989), were calculated for the Toutle River where the sediment supply was increased as a result of the eruption of Mount St. Helens in 1980. Some of the highest efficiencies ( 7.5 percent, based on data reported by Lekach and Schick, 1983; Lekach and others, 1992) occur in the desert, where unsteady flow or flash floods are also the dominant transport process. The relatively high bed-load transport efficiency 
is probably a result of steep channel slopes, increased sediment supply, and the mixed grain sizes in the bed material.

\section{Initiation of Motion for Bed Load}

Critical thresholds for bed-load movement in mixed-grain-size beds were very different than those for uniform grains. In general, particles less than about $11 \mathrm{~mm}$ in diameter were always moving on the bed of Buffalo and Spring Creeks so that the critical shear stress was only determined for larger particles. It ranged from $5.4 \mathrm{~N} / \mathrm{m}^{2}$ for particle diameters of $11 \mathrm{~mm}$ to $470 \mathrm{~N} / \mathrm{m}^{2}$ for a boulder-size particle (diameter of about $1000 \mathrm{~mm}$ ). The latter value is similar to the critical shear stress $\left(480 \mathrm{~N} / \mathrm{m}^{2}\right)$ extrapolated for a $1000 \mathrm{~mm}$ particle reported by Leopold and others (1964, figure 6-11, p. 170). Non-dimensional shear stress, $\tau^{*}$, which is given by

$$
\tau^{*}=\tau /\left(g\left(\rho_{s}-\rho\right) D_{b}\right)
$$

where $\tau$ is the bed shear stress, $\rho_{s}$ and $\rho$ are the density of the sediment and water, and $D_{b}$ is the median diameter of the largest size-class transported as bed load. For the conditions of a mixed grain-size bed, the non-dimensional shear stress decreases with an increase in the relative roughness, $D_{b} / h$ (fig. 6.5). These relations for the critical shear stress, $\tau^{*}{ }_{c}$, in Buffalo and Spring Creeks are

$$
\tau_{c}^{*}=0.0059\left(D_{b} / h\right)^{-1.2} \quad r^{2}=0.86,
$$

and

$$
\tau_{c}^{*}=10.020\left(D_{b} / h\right)^{-0.88} \quad r^{2}=0.80
$$

The data point shown as an open circle (fig. 6.5) corresponds to low shear stress conditions and when very little sand was on the bed of Buffalo Creek such that a bed of mixed grain sizes was not present (4 June 2000). This point was not included in the regression above. In contrast, data reported by Suszka (1991) for several laboratory experiments, done with a bed of uniform grains indicate that the non-dimensional shear stress increases with increase in the relative roughness, $D_{b} / h$

$$
\tau_{c}^{*}=0.092\left(D_{b} / h\right)^{0.32}, \quad r^{2}=0.87
$$

That is, the non-dimension shear stress increases with an increase in relative roughness (fig. 6.5). This result for uniform grains was thought to be caused by the increase in eddies (Nakagawa and others, 1991; Suszka, 1991; and Tsujimoto, 1991) being shed near the bed as the relative roughness increased. Thus, the vertical shear and Reynolds stresses decreased and more of the total shear stress is required to move the particle. At present, for beds with mixed grain sizes, the explanation is not completely understood, but it is probably a result of the decrease in the friction or pocket angle for large particles on a bed of smaller particles, and the corresponding increased exposure of large particles to the shear. This increase in the transport of larger particles in the presence of smaller particles was first noted by Gilbert (1914) in his flume experiments with sediment mixtures. 


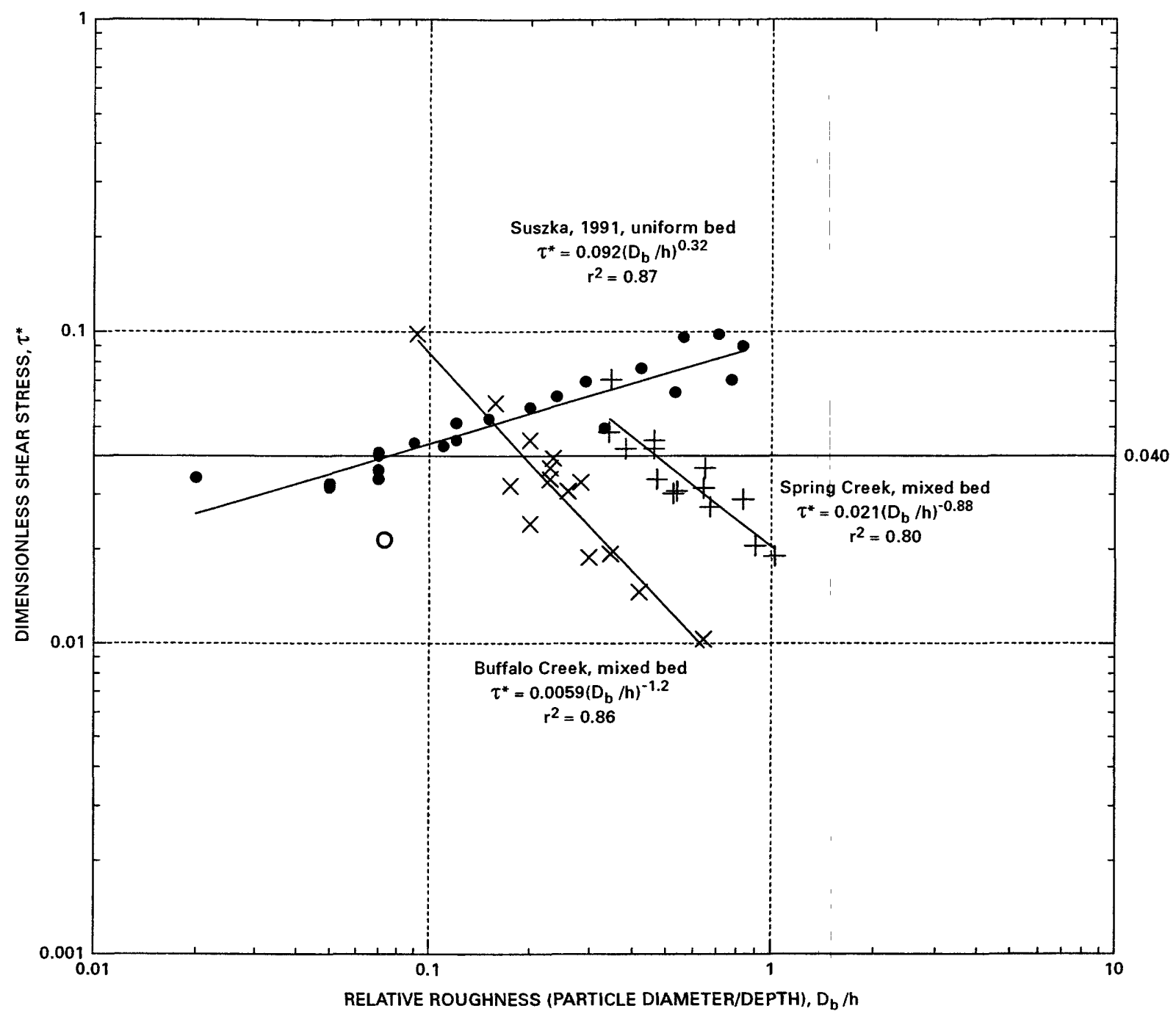

Figure 6.5. Initiation of motion of bed material as a function of relative roughness. Samples were collected in Buffalo Creek (X's) and Spring Creek (+'s). Dimensionless shear stress is defined in the text. The data for uniform bed material were measured in the laboratory and are shown as solid circles. The open circle corresponds to conditions in Buffalo Creek of low shear stress and almost no sand on the bed such that a bed of mixed grain sizes was not present. This point was not included in the regression

\section{Mobility of Coarse Sediment}

The particle-size data for the bed-load samples (table 6.3) were analyzed to investigate the mobility of coarse particles $(>4 \mathrm{~mm})$ in Spring Creek. For each size class, the ratio of the percent of sediment transported to the percent of sediment available for transport was calculated (table 6.11). The percent available for transport was determined by recalculating the particle-size distribution of the bed material (table 6.1) when those sizes which did not move were excluded. The ratio for the median-size class (4-8 mm) was about 0.85 for Spring Creek and 0.95 for Buffalo Creek. The data suggest a maximum for particle sizes larger (about 8-16 mm) than the 4-8 mm size class (fig. 6.6). The maximum ratio was for the $16-32 \mathrm{~mm}$ size class and was associated with 
the maximum bed shear stress $\left(28 \mathrm{~N} / \mathrm{m}^{2}\right)$. In general, the maximum ratio decreased and the corresponding particle size decreased as the bed shear stress decreased; however, there were exceptions, like 28 June 1997. These data seem to indicate that particles coarser than the median grain size may be preferentially transported in Spring Creek. In Buffalo Creek, the sediment coarser than the median size class (2-4 mm) generally did not appear to be preferentially transported (table 6.12) because the increase in sediment transport was usually less than 20 percent (a typical error for sediment measurements) of the sediment available in the bed. This may be because the relative roughness and bed slope are generally less than in Spring Creek or because of the difference in the sediment-size distribution of the bed material (fig. 6.2).

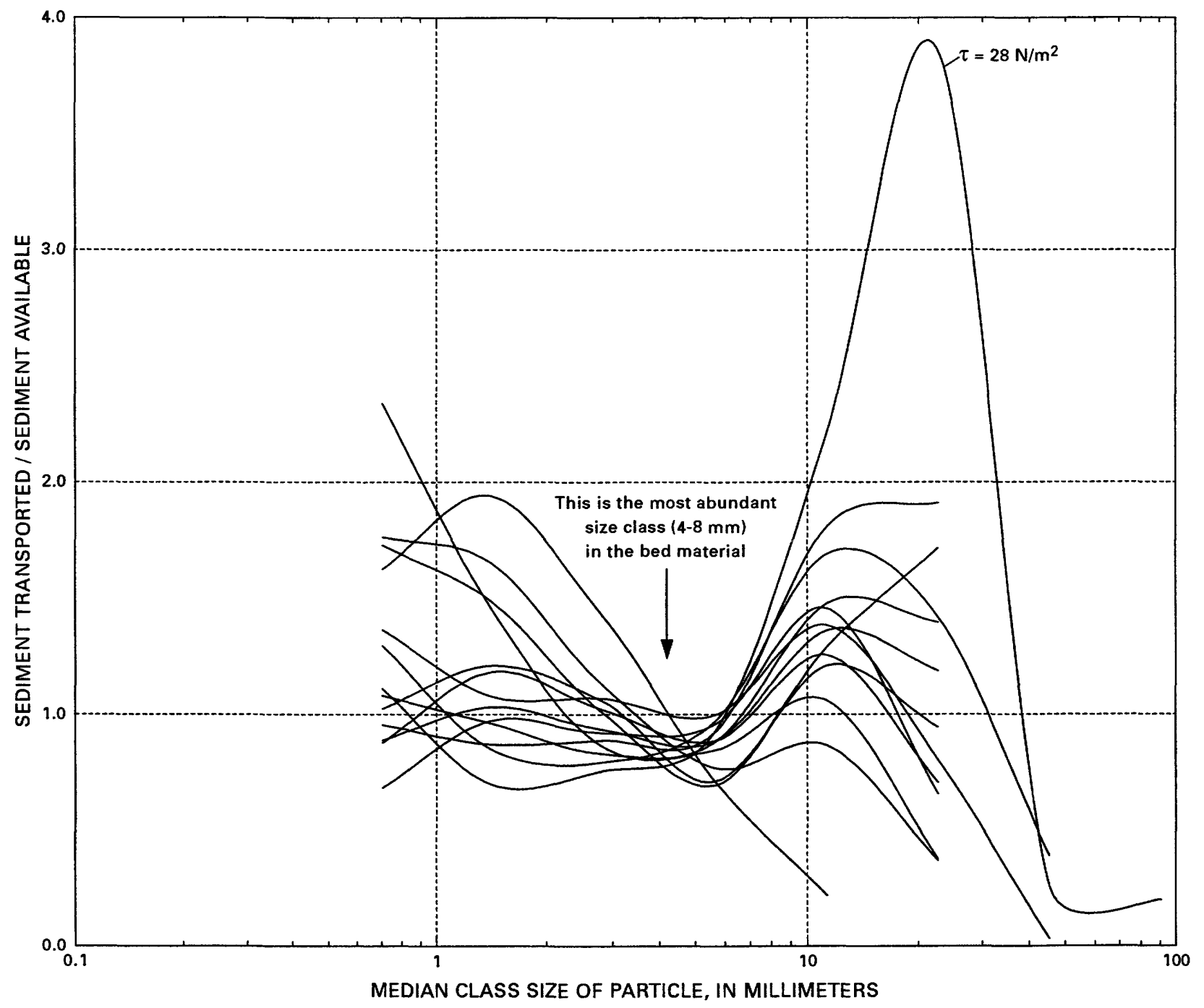

Figure 6.6. Relative mobility of coarse sediment in Spring Creek. Sediment available for transport is based on data in table 6.1 and figure 6.2. Sediment transported is listed in table 6.3. 


\section{Transport Regimes}

Three different transport regimes (uniform, discontinuous, and unsteady) existed at different times and for varying lengths of time in Spring Creek (Moody, 2001). The uniform regime had steady and spatially continuous flow and both non-cohesive and cohesive (frozen) bed conditions, depending upon the time of year. This relatively uniform transport regime existed when the water discharge ranged from $0.074-0.21 \mathrm{~m}^{3} / \mathrm{s}$ in the early spring and during the summer. Streamflow was the result of snowmelt and elevated baseflow from summer rains percolating into the highly fractured Pikes Peak granite. The discontinuous regime occurred with very low discharge $(<0.01$ $\mathrm{m}^{3} / \mathrm{s}$ ) flowing over the non-cohesive surficial sediment. This regime frequently occurred during the summer. Streamflow was discontinuous, with flow disappearing into the bed, depositing bed load, and leaving a convex cross-channel profile. This type of deposit had a stoss slope slightly less than the slope of the bed in the downstream direction and a lee slope much greater than the bed slope. Downstream from the base of the lee slope the water reappeared, eroding a channel. The unsteady regime existed for a relatively short time when the discharge changed from $0.02-$ $0.20 \mathrm{~m}^{3} / \mathrm{s}$ to $20-180 \mathrm{~m}^{3} / \mathrm{s}$ during flash floods. In Spring Creek, flash floods accounted for 67 percent of the sediment transported from the watershed and steady-flow conditions accounted for 33 percent, while in Buffalo Creek flash floods accounted for 15 percent and steady-flow conditions accounted for 85 percent of the sediment transported.

\section{Bed-Load and Suspended-Load Rating Curves}

The total sediment rating curve (fig. 6.4) was separated into two rating curves for bed load and suspended load. The direct and indirect measurements of bed-load and suspended-load transport per unit width were combined to produce sediment rating curves for Spring Creek (fig. 6.7) but only direct measurements were used for Buffalo Creek (fig. 6.8). Bed-load transport per unit width in both Spring and Buffalo Creeks was greater than the suspended-load transport. At very high unit discharges, greater than those sampled, extrapolation of the data suggest that the suspended load in Spring Creek may exceed the bed load. 


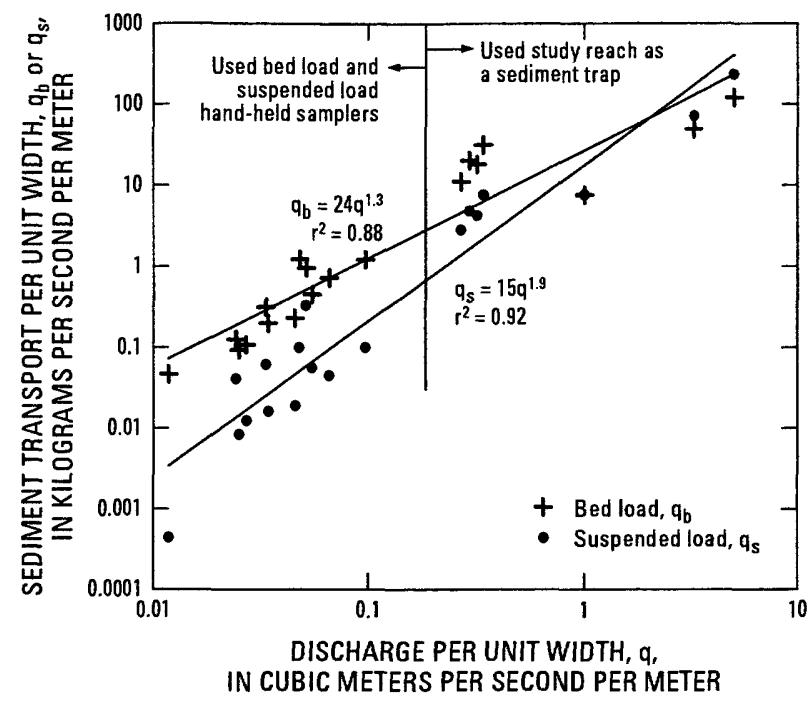

Figure 6.7. Bed-load and suspended-load transport per unit width as a function of water discharge per unit width in Spring Creek. Bed-load measurements, $q_{b}$, are shown as plus symbols and suspended-load measurements, $q_{s}$, are shown as solid circles.

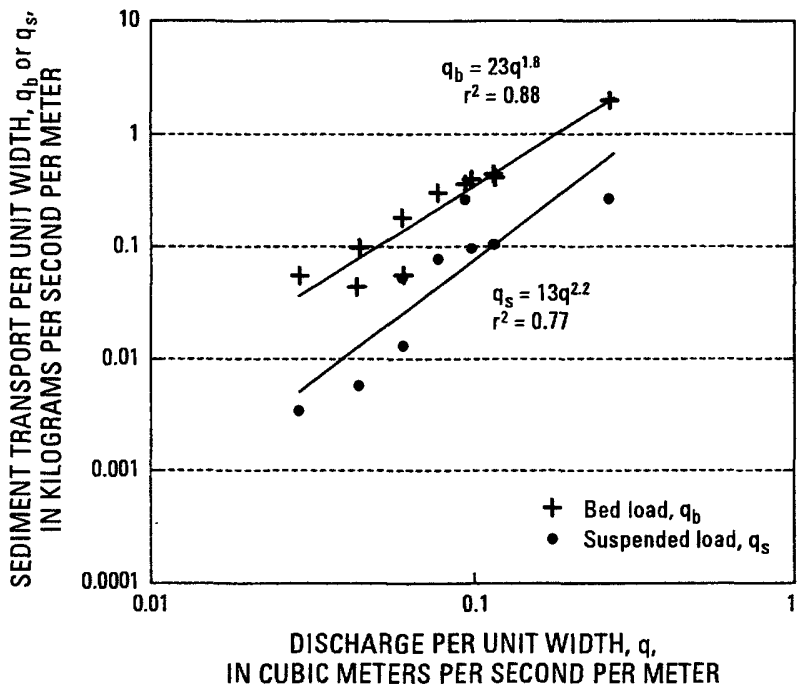

Figure 6.8 Bed-load and suspended-load transport per unit width as a function of water discharge per unit width in Buffalo Creek. Bed-load measurements, $q_{b}$, are shown as plus symbols and suspended-load measurements, $q_{s}$, are shown as solid circles. 


\section{Summary}

The bed material in Buffalo and Spring Creeks after the wildfire and floods in 1996 was an unsorted mixture ranging in size from silt to boulders, but with median diameters of about 3 and $6 \mathrm{~mm}$, respectively. Spring Creek had a second mode of rocks and boulders sapped from the side walls of the channels. Bed material in the Spring Creek watershed coarsened slightly in the downstream direction. Based on the data for Buffalo Creek, the total sediment transport after the wildfire was about 10 times greater than before the wildfire, and the transport in Spring Creek after the wildfire was 5-10 times greater than transport in Buffalo Creek after the wildfire. Field measurements of the dimensionless critical shear stress, $\tau^{*}{ }_{c}$, for the initiation of motion in these mixed-grain size systems indicate $\tau^{*}$ decreases with an increase in relative roughness, contrary to laboratory results for uniform grain sizes. Data collected in Spring Creek indicate that the coarse grain sizes $(>4 \mathrm{~mm})$ are preferentially transported, which is supported by the observation that the bed material coarsens downstream. 
Table 6.1. Summary of the particle-size distribution of surficial bed material in Spring Creek and Buffalo Creek after the wildfire and floods in 1996

[mm, millimeter; kg, kilogram; Tributary 2.25 is 2.25 miles, Tributary 3.1 is 3.1 miles, and Tributary 3.11 is

3.11 miles from the intersection of Forest Road 550 and Forest Road 543; C.I. = confidence limits]

\begin{tabular}{|c|c|c|c|c|c|c|c|c|c|c|c|c|c|c|}
\hline \multirow[b]{2}{*}{ Site } & \multicolumn{11}{|c|}{ Percent of total } & \multicolumn{3}{|r|}{ Comment } \\
\hline & $\begin{array}{c}< \\
0.063 \\
\mathrm{~mm}\end{array}$ & $\begin{array}{c}0.063 \\
- \\
0.125 \\
\mathbf{m m}\end{array}$ & $\begin{array}{c}0.125 \\
- \\
0.250 \\
\text { mm }\end{array}$ & $\begin{array}{c}0.250 \\
- \\
0.500 \\
\mathbf{m m}\end{array}$ & $\begin{array}{c}0.500 \\
-1.00 \\
\mathrm{~mm}\end{array}$ & $\begin{array}{l}1-2 \\
\mathbf{m m}\end{array}$ & $\begin{array}{l}2-4 \\
\mathbf{m m}\end{array}$ & $\begin{array}{l}4-8 \\
\mathrm{~mm}\end{array}$ & $\begin{array}{l}8-16 \\
\text { mm }\end{array}$ & $\begin{array}{c}16-32 \\
\mathrm{~mm}\end{array}$ & $\begin{array}{c}32-64 \\
\mathrm{~mm}\end{array}$ & $\begin{array}{l}64- \\
128 \\
\mathrm{~mm}\end{array}$ & $\begin{array}{c}> \\
128 \\
\mathbf{m m}\end{array}$ & \\
\hline \multicolumn{15}{|c|}{ Spring Creek } \\
\hline Mouth & 1.6 & 1.3 & 1.2 & 2.3 & 3.3 & 7.5 & 17.2 & 26.9 & 10.9 & 2.9 & 6.6 & 10.3 & 8.0 & $\begin{array}{l}\text { A single } 53 \mathrm{~kg} \text { surficial } \\
\text { sample was collected at } \\
\text { the mouth and used to } \\
\text { determine the distribu- } \\
\text { tion of particle sizes } \\
\text { less than } 128 \mathrm{~mm} \text {. } \\
\text { Aerial mapping was } \\
\text { used to determine the } \\
\text { amount of particles } \\
\text { greater than } 128 \mathrm{~mm} \text {. }\end{array}$ \\
\hline \multicolumn{15}{|c|}{ Buffalo Creek } \\
\hline Mouth & 0.2 & 1.3 & 4.5 & 9.5 & 11.3 & 17.8 & 22.5 & 21.7 & 8.1 & 1.6 & 1.3 & 0.0 & & $\begin{array}{l}\text { A single } 10 \mathrm{~kg} \text { surficial } \\
\text { sample was collected } \\
\text { about } 100 \mathrm{~m} \text { upstream } \\
\text { from the mouth. }\end{array}$ \\
\hline \multicolumn{15}{|c|}{ Tributaries to Buffalo Creek } \\
\hline $\begin{array}{c}\text { Tributary } \\
2.25\end{array}$ & 0.1 & 0.4 & 1.7 & 8.1 & 23.7 & 29.7 & 20.1 & 16.2 & 0.0 & 0.0 & 0.0 & 0.0 & & $\begin{array}{l}\text { A channel sample was } \\
\text { collected about } 40 \mathrm{~m} \\
\text { upstream from mouth. }\end{array}$ \\
\hline $\begin{array}{c}\text { Tributary } \\
2.25\end{array}$ & 0.1 & 0.3 & 1.3 & 5.7 & 18.7 & 34.6 & 32.3 & 7.0 & 0.0 & 0.0 & 0.0 & 0.0 & & $\begin{array}{l}\text { A channel sample was } \\
\text { collected about } 320 \mathrm{~m} \\
\text { upstream from mouth. }\end{array}$ \\
\hline $\begin{array}{c}\text { Tributary } \\
2.25\end{array}$ & 0.1 & 0.4 & 1.3 & 3.6 & 11.5 & 28.1 & 40.4 & 14.4 & 0.2 & 0.0 & 0.0 & 0.0 & & $\begin{array}{l}\text { A channel sample was } \\
\text { collected about } 440 \mathrm{~m} \\
\text { upstream from mouth. }\end{array}$ \\
\hline $\begin{array}{c}\text { Tributary } \\
3.1\end{array}$ & 0.1 & 0.2 & 0.6 & 2.3 & 6.5 & 17.4 & 32.5 & 32.1 & 8.2 & 0.0 & 0.0 & 0.0 & & $\begin{array}{l}\text { A channel sample was } \\
\text { collected about } 100 \mathrm{~m} \\
\text { upstream from mouth. }\end{array}$ \\
\hline $\begin{array}{c}\text { Tributary } \\
3.11\end{array}$ & 0.2 & 0.8 & 4.0 & 11.6 & 22.2 & 24.3 & 29.7 & 6.6 & 0.5 & 0.0 & 0.0 & 0.0 & & $\begin{array}{l}\text { Collected sample from an } \\
\text { alluvial fan at the } \\
\text { mouth next to Forest } \\
\text { Road } 543 .\end{array}$ \\
\hline Mean & 0.1 & 0.4 & 1.8 & 6.3 & 16.5 & 26.8 & 31.0 & 15.3 & 1.8 & 0.0 & 0.0 & 0.0 & & \\
\hline $95 \%$ C.I. & 0.1 & 0.3 & 1.7 & 4.7 & 8.8 & 8.8 & 10.4 & 13.0 & 4.2 & 0.0 & 0.0 & 0.0 & & \\
\hline
\end{tabular}


Table 6.2. Summary of the particle-size distribution of surficial bed material in the Spring Creek channel and one of its tributaries after the wildfire and floods in 1996 and 1997

[mm, millimeter; m, meter; medium size (1-3 kilogram) samples were collected 24 April 1998; $D_{84}=84$ percent are finer than this diameter; $D_{50}=50$ percent are finer than this diameter; $D_{16}=16$ percent are finer than this diameter; $\left.\sigma=\sqrt{D_{84} / D_{16}}\right]$

\begin{tabular}{|c|c|c|c|c|c|c|c|c|c|c|c|c|c|c|c|}
\hline \multirow{2}{*}{$\begin{array}{l}\text { Distance } \\
\text { upstream } \\
\text { from the } \\
\text { mouth } \\
\text { (m) }\end{array}$} & \multicolumn{11}{|c|}{ Percent of total } & \multirow[b]{2}{*}{$\begin{array}{c}D_{16} \\
(\mathrm{~mm})\end{array}$} & \multirow[b]{2}{*}{$\begin{array}{c}D_{50} \\
(\mathbf{m m})\end{array}$} & \multirow[b]{2}{*}{$\begin{array}{c}D_{84} \\
(\mathbf{m m})\end{array}$} & \multirow[b]{2}{*}{$\boldsymbol{\sigma}$} \\
\hline & $\begin{array}{c}< \\
0.063 \\
\mathrm{~mm}\end{array}$ & $\begin{array}{c}0.063 \\
- \\
0.125 \\
\mathrm{~mm}\end{array}$ & $\begin{array}{c}0.125 \\
- \\
0.250 \\
\mathrm{~mm}\end{array}$ & $\begin{array}{c}0.250 \\
- \\
0.500 \\
\mathrm{~mm}\end{array}$ & $\begin{array}{c}0.500 \\
-1.00 \\
\mathrm{~mm}\end{array}$ & $\begin{array}{l}1-2 \\
\mathrm{~mm}\end{array}$ & $\begin{array}{c}2-4 \\
\mathrm{~mm}\end{array}$ & $\begin{array}{l}4-8 \\
\mathrm{~mm}\end{array}$ & $\begin{array}{l}8-16 \\
\mathrm{~mm}\end{array}$ & $\begin{array}{c}16-32 \\
\mathrm{~mm}\end{array}$ & $\begin{array}{c}32-64 \\
\mathrm{~mm}\end{array}$ & & & & \\
\hline \multicolumn{16}{|c|}{ Main channel of Spring Creek and up a tributary with its mouth 5,060 m upstream from the mouth of Spring Creek } \\
\hline $6,2600^{\mathrm{a}}$ & 1.1 & 1.5 & 4.1 & 13.8 & 21.3 & 16.5 & 23.8 & 16.7 & 1.2 & 0.0 & 0.0 & 0.42 & 1.5 & 4.5 & 3.3 \\
\hline $6,260^{\mathrm{b}}$ & 0.4 & 0.9 & 2.7 & 11.1 & 23.6 & 34.8 & 19.2 & 6.5 & 0.7 & 0.0 & 0.0 & 0.52 & 1.3 & 3.1 & 2.4 \\
\hline 5,060 & 0.9 & 0.8 & 2.1 & 6.4 & 14.8 & 20.2 & 20.3 & 18.1 & 11.0 & 5.3 & 0.0 & 0.70 & 2.5 & 8.0 & 3.4 \\
\hline 4,850 & 2.8 & 1.6 & 2.8 & 6.2 & 11.9 & 19.9 & 32.3 & 20.1 & 2.4 & 0.0 & 0.0 & 0.55 & 2.3 & 5.3 & 3.1 \\
\hline 4,200 & 2.4 & 2.3 & 3.1 & 4.1 & 7.5 & 15.0 & 25.3 & 27.7 & 12.1 & 0.4 & 0.0 & 0.77 & 3.2 & 7.5 & 3.1 \\
\hline 3,470 & 1.0 & 0.8 & 1.2 & 3.4 & 6.5 & 11.0 & 20.1 & 33.6 & 21.3 & 1.0 & 0.0 & 1.3 & 4.7 & 10.4 & 2.8 \\
\hline 2,600 & 1.1 & 1.0 & 1.2 & 2.2 & 6.1 & 14.0 & 23.0 & 29.2 & 19.7 & 2.6 & 0.0 & 1.3 & 4.2 & 10.6 & 2.9 \\
\hline $0^{c}$ & 1.4 & 0.9 & 1.5 & 3.5 & 6.5 & 12.8 & 21.4 & 28.9 & 17.1 & 6.2 & 0.0 & 1.2 & 4.3 & 11.3 & 3.1 \\
\hline \multicolumn{16}{|c|}{ Tributary begins $2,180 \mathrm{~m}$ upstream from the mouth of Spring Creek } \\
\hline 900 & 1.9 & 2.4 & 6.0 & 14.1 & 18.9 & 24.4 & 25.8 & 5.9 & 0.2 & 0.3 & 0.0 & 0.35 & 1.3 & 3.3 & 3.1 \\
\hline 0 & 1.3 & 1.1 & 1.4 & 4.5 & 11.5 & 21.9 & 30.4 & 20.7 & 5.8 & 1.2 & 0.0 & 0.83 & 2.5 & 6.3 & 2.8 \\
\hline
\end{tabular}

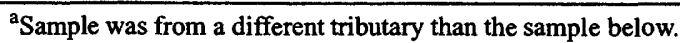

' bample was from a different tributary than the sample above.

'Sample was collected on 12 December 1996. 


\section{Table 6.3. Summary of the particle-size distribution of replicate samples of bed and}

suspended load collected near the mouth of Spring Creek, 1997-2000

[This table contains raw values; bed load is all the sediment that is collected in a USBLH-84 sampler, and suspended load is all the sediment collected by the pint-jar sampler with an isokinetic nozzle; dry masses have been used in calculating transport rates and concentrations; some sizes of bed load may have been in suspension depending upon the water discharge; $\mathrm{mm}$, millimeter; $\mathrm{kg} / \mathrm{s}$, kilogram per second; $\mathrm{mg} / \mathrm{L}$, milligram per liter; $\mathrm{m}^{3} / \mathrm{s}$, cubic meter per second; *, some organic material]

\begin{tabular}{|c|c|c|c|c|c|c|c|c|c|c|c|c|c|c|c|c|}
\hline \multirow[b]{2}{*}{$\begin{array}{c}\text { Replic } \\
\text { ate }\end{array}$} & \multicolumn{9}{|c|}{ Bed load (percent of total) } & \multicolumn{7}{|c|}{ Suspended load (percent of total) } \\
\hline & $\begin{array}{c}0.250- \\
0.500 \\
\mathrm{~mm}\end{array}$ & $\begin{array}{l}0.500- \\
1.00 \\
\mathrm{~mm}\end{array}$ & $\begin{array}{l}1-2 \\
\mathrm{~mm}\end{array}$ & $\begin{array}{l}2-4 \\
\mathrm{~mm}\end{array}$ & $\begin{array}{l}4-8 \\
\mathrm{~mm}\end{array}$ & $\begin{array}{l}8-16 \\
\mathrm{~mm}\end{array}$ & $\begin{array}{c}16-32 \\
\mathrm{~mm}\end{array}$ & $\begin{array}{c}32-64 \\
\mathrm{~mm}\end{array}$ & $\begin{array}{l}\text { Trans- } \\
\text { port } \\
\text { rate } \\
(\mathrm{kg} / \mathrm{s})\end{array}$ & $\begin{array}{c}< \\
0.063 \\
\mathrm{~mm}\end{array}$ & $\begin{array}{c}0.063- \\
0.125 \\
\mathrm{~mm}\end{array}$ & $\begin{array}{c}0.125- \\
0.250 \\
\mathrm{~mm}\end{array}$ & $\begin{array}{c}0.250- \\
0.500 \\
\mathrm{~mm}\end{array}$ & $\begin{array}{c}0.500- \\
1.00 \\
\mathrm{~mm}\end{array}$ & $\begin{array}{l}1-2 \\
\mathrm{~mm}\end{array}$ & $\begin{array}{c}\text { Concen- } \\
\text { tration } \\
\text { (mg/L) }\end{array}$ \\
\hline & \multicolumn{16}{|c|}{ Wooden Parshall flume at the mouth of Spring Creek, 28 June $1997,0.016 \mathrm{~m}^{3} / \mathrm{s}$} \\
\hline 1 & 1.1 & 5.1 & 16.9 & 26.9 & 31.6 & 16.0 & 2.3 & 0 & 0.10 & 17.2 & 60.5 & 17.8 & *4.5 & 0 & 0 & 780 \\
\hline 2 & 5.2 & 11.1 & 18.5 & 23.1 & 26.1 & 15.1 & 0.9 & 0 & 0.078 & 13.9 & 52.4 & 24.9 & $* 8.8$ & 0 & 0 & 2200 \\
\hline 3 & 1.4 & 6.5 & 16.0 & 26.8 & 31.8 & 14.9 & 2.4 & 0 & 0.076 & \multicolumn{7}{|c|}{ no replicate was collected } \\
\hline 4 & 2.9 & 10.3 & 18.9 & 33.1 & 27.1 & 7.3 & 0.4 & 0 & 0.056 & \multicolumn{7}{|c|}{ no replicate was collected } \\
\hline \multicolumn{17}{|c|}{ Wooden Parshall flume at the mouth of Spring Creek, 2 July $1997,0.0078 \mathrm{~m}^{3} / \mathrm{s}$} \\
\hline 1 & 4.1 & 5.8 & 14.6 & 27.6 & 29.9 & 13.2 & 4.7 & 0 & 0.015 & 51.0 & 26.6 & 15.6 & 6.8 & 0 & 0 & 34 \\
\hline 2 & 0.2 & 0.8 & 8.1 & 24.1 & 37.3 & 24.3 & 5.0 & 0 & 0.021 & \multicolumn{7}{|c|}{ no replicate was collected } \\
\hline 3 & 0.5 & 2.1 & 9.4 & 22.9 & 37.2 & 25.8 & 2.1 & 0 & 0.030 & 35.6 & 37.3 & 19.7 & 4.1 & 3.3 & 0 & 33 \\
\hline 4 & 1.0 & 5.4 & 16.1 & 24.7 & 31.1 & 19.7 & 2.0 & 0 & 0.039 & \multicolumn{7}{|c|}{ no replicate was collected } \\
\hline 5 & 2.0 & 6.6 & 15.3 & 26.2 & 34.4 & 14.9 & 0.8 & 0 & 0.033 & \multicolumn{7}{|c|}{ no replicate was collected } \\
\hline \multicolumn{17}{|c|}{ At gaging site on Spring Creek, 2 July $1997,<0.1 \mathrm{~m}^{3} / \mathrm{s}$} \\
\hline 1 & 12.5 & 13.0 & 12.9 & 15.7 & 23.0 & 23.5 & 0 & 0 & 0.0010 & \multicolumn{7}{|c|}{ no samples } \\
\hline 2 & 8.2 & 11.7 & 17.5 & 26.4 & 18.9 & 17.3 & 0 & 0 & 0.0013 & & & & no sampl & & & \\
\hline \multicolumn{17}{|c|}{ Wooden Parshall flume at the mouth of Spring Creek, $11 \mathrm{July} 1997,0.0036 \mathrm{~m}^{3} / \mathrm{s}$} \\
\hline 1 & 6.3 & 6.3 & 21.9 & 50.0 & 15.6 & 0 & 0 & 0 & 0.000080 & 75.6 & 13.5 & 6.6 & $* 4.4$ & 0 & 0 & 38 \\
\hline 2 & 1.8 & 8.3 & 22.9 & 28.4 & 38.5 & 0 & 0 & 0 & 0.00027 & 64.5 & 19.7 & 7.0 & 4.2 & 4.7 & 0 & 49 \\
\hline 3 & 2.6 & 9.0 & 19.2 & 29.5 & 29.5 & 10.3 & 0 & 0 & 0.00020 & 77.9 & 10.9 & 7.3 & 3.0 & 0.9 & 0 & 107 \\
\hline \multicolumn{17}{|c|}{ Wooden Parshall flume at the mouth of Spring Creek, 3 August $1997,0.022 \mathrm{~m}^{3} / \mathrm{s}$} \\
\hline 1 & 3.3 & 2.9 & 5.2 & 16.4 & 42.0 & 26.7 & 3.5 & 0 & 0.10 & 45.7 & 10.1 & 28.3 & 11.5 & 4.4 & 0 & 1700 \\
\hline 2 & 4.8 & 9.0 & 11.5 & 23.3 & 28.9 & 19.5 & 3.1 & 0 & 0.24 & 51.6 & 18.2 & 20.0 & 5.4 & 4.8 & 0 & 1400 \\
\hline 3 & 2.7 & 6.6 & 11.3 & 25.1 & 34.9 & 15.1 & 3.4 & 0.9 & 0.26 & 52.3 & 14.5 & 27.2 & 2.9 & 3.1 & 0 & 1900 \\
\hline 4 & 2.5 & 4.6 & 13.5 & 29.5 & 31.7 & 16.2 & 1.9 & 0 & 0.16 & 51.4 & 16.6 & 17.1 & 9.8 & 5.1 & 0 & 1200 \\
\hline \multicolumn{17}{|c|}{ Wooden Parshall flume at the mouth of Spring Creek, 5 August $1997,0.034 \mathrm{~m}^{3} / \mathrm{s}$} \\
\hline 1 & 3.9 & 7.0 & 9.8 & 17.7 & 25.8 & 25.9 & 9.9 & 0 & 0.56 & 45.6 & 11.7 & 35.2 & 4.9 & 2.6 & 0 & 5500 \\
\hline 2 & 3.5 & 3.8 & 4.1 & 10.9 & 24.9 & 31.0 & 19.0 & 2.8 & 0.42 & 56.3 & 19.1 & 13.8 & 6.7 & $* 3.0$ & ${ }^{*} 1.0$ & 4800 \\
\hline 3 & 1.2 & 1.0 & 2.1 & 13.7 & 33.8 & 26.2 & 9.9 & $3.1^{\mathrm{a}}$ & 0.62 & 48.0 & 14.3 & 26.5 & 6.6 & $* 3.5$ & ${ }^{*} 1.1$ & 6800 \\
\hline 4 & 3.4 & 4.8 & 7.6 & 16.4 & 27.8 & 26.4 & 11.9 & 1.7 & 0.74 & 48.2 & 31.5 & 12.7 & $* 4.2$ & $* 2.1$ & ${ }^{*} 1.2$ & 6000 \\
\hline \multicolumn{17}{|c|}{ Mouth of Spring Creek, 15 September $1997,0.040 \mathrm{~m}^{3} / \mathrm{s}$} \\
\hline 1 & 5.2 & 7.2 & 9.1 & 17.1 & 25.6 & 21.7 & 14.1 & 0 & 0.12 & 47.3 & 19.1 & 16.0 & 12.6 & 5.0 & 0 & 330 \\
\hline 2 & 1.4 & 3.7 & 15.9 & 28.1 & 25.4 & 20.5 & 5.0 & 0 & 0.14 & 60.5 & 18.0 & 13.4 & 4.7 & 3.3 & 0 & 290 \\
\hline 3 & 1.6 & 2.4 & 8.1 & 28.5 & 31.7 & 22.1 & 5.6 & 0 & 0.14 & 60.0 & 22.6 & 10.5 & 4.3 & 2.6 & 0.2 & 370 \\
\hline 4 & 2.6 & 5.8 & 18.3 & 29.3 & 25.2 & 15.4 & 3.5 & 0 & 0.19 & 39.7 & 18.5 & 25.6 & 10.8 & 5.4 & 0 & 470 \\
\hline
\end{tabular}


Table 6.3. (Continued) Summary of the particle-size distribution of rephicate samples of bed and suspended load collected near the mouth of Spring Creek, 1997-2000

\begin{tabular}{|c|c|c|c|c|c|c|c|c|c|c|c|c|c|c|c|c|}
\hline \multirow[b]{2}{*}{$\begin{array}{c}\text { Replic } \\
\text { ate }\end{array}$} & \multicolumn{9}{|c|}{ Bed load (percent of total) } & \multicolumn{7}{|c|}{ Suspended load (percent of total) } \\
\hline & $\begin{array}{c}0.250- \\
0.500 \\
\mathrm{~mm}\end{array}$ & $\begin{array}{l}0.500- \\
1.00 \\
\mathrm{~mm}\end{array}$ & $\begin{array}{l}1-2 \\
\mathbf{m m}\end{array}$ & $\begin{array}{c}2-4 \\
\mathrm{~mm}\end{array}$ & $\begin{array}{l}4-8 \\
\mathrm{~mm}\end{array}$ & $\begin{array}{l}8-16 \\
\mathrm{~mm}\end{array}$ & $\begin{array}{c}16-32 \\
\mathrm{~mm}\end{array}$ & $\begin{array}{c}32-64 \\
\mathrm{~mm}\end{array}$ & $\begin{array}{c}\text { Trans- } \\
\text { port } \\
\text { rate } \\
(\mathrm{kg} / \mathrm{s})\end{array}$ & $\begin{array}{c}< \\
0.063 \\
\mathrm{~mm}\end{array}$ & $\begin{array}{c}0.063- \\
0.125 \\
\mathrm{~mm}\end{array}$ & $\begin{array}{c}0.125- \\
0.250 \\
\mathrm{~mm}\end{array}$ & $\begin{array}{c}0.250- \\
0.500 \\
\mathrm{~mm}\end{array}$ & $\begin{array}{c}0.500- \\
1.00 \\
\mathbf{m m}\end{array}$ & $\begin{array}{l}1-2 \\
\mathrm{~mm}\end{array}$ & $\begin{array}{c}\text { Concen- } \\
\text { tration } \\
\text { (mg/L) }\end{array}$ \\
\hline \multicolumn{17}{|c|}{ Mouth of Spring Creek, 8 October $1997,0.023 \mathrm{~m}^{3} / \mathrm{s}$} \\
\hline 1 & 0.6 & 3.8 & 16.5 & 31.4 & 29.3 & 14.9 & 3.5 & 0 & 0.092 & \multicolumn{7}{|c|}{ not available } \\
\hline 2 & 8.6 & 9.1 & 16.1 & 22.7 & 22.9 & 17.4 & 3.3 & 0 & 0.029 & 51.8 & 26.9 & 14.9 & 5.0 & 1.3 & 0 & 180 \\
\hline 3 & 5.0 & 11.0 & 14.5 & 20.1 & 27.0 & 19.8 & 2.6 & 0 & 0.14 & 51.8 & 28.8 & 11.3 & 3.9 & 4.1 & 0 & 180 \\
\hline 4 & 4.0 & 7.8 & 15.0 & 22.1 & 24.0 & 21.2 & 5.8 & 0 & 0.063 & 26.4 & 13.4 & 29.0 & 22.4 & 8.8 & 0 & 310 \\
\hline \multicolumn{17}{|c|}{ Mouth of Spring Creek, 21 May 1998, $0.16 \mathrm{~m}^{3} / \mathrm{s}$} \\
\hline 1 & 3.7 & 6.8 & 9.4 & 14.4 & 27.9 & 21.3 & 6.7 & 9.9 & 0.78 & 33.9 & 12.5 & 13.6 & 29.7 & 8.6 & 1.7 & 1400 \\
\hline 2 & 4.2 & 4.8 & 6.4 & 18.8 & 33.6 & 25.1 & 3.9 & 3.1 & 1.15 & 30.0 & 16.5 & 24.5 & 20.0 & 7.7 & 1.2 & 1400 \\
\hline 3 & 3.4 & 3.7 & 5.2 & 15.5 & 39.4 & 26.8 & 6.0 & 0 & 1.43 & 55.8 & 17.1 & 15.7 & 7.4 & 3.3 & 0.7 & 580 \\
\hline 4 & 2.5 & 6.6 & 11.6 & 21.0 & 32.5 & 21.4 & 4.5 & 0 & 1.39 & 50.7 & 17.4 & 14.0 & 10.4 & 5.6 & 1.9 & 550 \\
\hline \multicolumn{17}{|c|}{ Mouth of Spring Creek, 26 June 1998, $0.074 \mathrm{~m}^{3} / \mathrm{s}$} \\
\hline 1 & 2.1 & 5.0 & 10.3 & 18.1 & 38.2 & 25.3 & 1.0 & 0 & 0.38 & 31.7 & 12.1 & 13.8 & 26.2 & 11.5 & 4.7 & 480 \\
\hline 2 & 1.1 & 1.8 & 12.0 & 22.5 & 36.0 & 22.8 & 3.8 & 0 & 0.34 & 34.3 & 15.1 & 16.0 & 22.9 & 9.8 & 1.8 & 620 \\
\hline 3 & 1.3 & 1.6 & 7.0 & 22.0 & 38.7 & 25.1 & 4.4 & 0 & 0.39 & 36.6 & 15.4 & 18.7 & 17.4 & 10.9 & 0.9 & 380 \\
\hline 4 & 2.7 & 4.4 & 12.3 & 27.6 & 33.9 & 17.5 & 1.6 & 0 & 0.46 & 40.9 & 16.4 & 16.2 & 17.3 & 3.6 & 5.6 & 510 \\
\hline \multicolumn{17}{|c|}{ Mouth of Spring Creek, 5 August 1998, $0.14 \mathrm{~m}^{3} / \mathrm{s}$} \\
\hline 1 & 3.8 & 7.0 & 13.0 & 17.5 & 26.9 & 25.8 & 6.0 & 0 & 2.7 & 40.3 & 17.5 & 10.7 & 15.8 & 10.0 & 5.6 & 1300 \\
\hline 2 & 1.1 & 2.4 & 7.8 & 17.2 & 35.6 & 27.2 & 8.7 & 0 & 3.0 & 39.6 & 19.0 & 13.7 & 14.9 & 9.1 & 3.7 & 1500 \\
\hline 3 & 1.0 & 3.0 & 10.9 & 27.1 & 35.4 & 17.9 & 4.8 & 0 & 3.2 & 41.1 & 19.6 & 11.0 & 11.7 & 10.4 & 6.2 & 2100 \\
\hline 4 & 4.3 & 7.8 & 9.1 & 19.0 & 35.8 & 20.5 & 3.5 & 0 & 5.0 & 28.9 & 13.0 & 11.9 & 15.0 & 20.7 & 10.5 & 2500 \\
\hline \multicolumn{17}{|c|}{ Mouth of Spring Creek, 15 May 1999, $0.100 \mathrm{~m}^{3} / \mathrm{s}$} \\
\hline 1 & 1.5 & 3.1 & 9.1 & 16.6 & 36.2 & 27.2 & 6.3 & 0 & 0.54 & 37.7 & 17.7 & 17.6 & 17.0 & 7.0 & 3.0 & 690 \\
\hline 2 & 2.7 & 6.3 & 9.1 & 23.2 & 34.7 & 19.5 & 4.5 & 0 & 1.6 & 28.4 & 11.2 & 21.9 & 24.7 & 13.0 & 0.7 & 770 \\
\hline 3 & 1.8 & 4.6 & 13.6 & 24.6 & 30.3 & 19.5 & 5.6 & 0 & 2.0 & 38.0 & 19.0 & 18.7 & 16.1 & 6.4 & 1.7 & 560 \\
\hline 4 & 0.9 & 2.7 & 12.4 & 27.3 & 34.6 & 18.7 & 3.3 & 0 & 1.6 & 23.5 & 21.3 & 29.9 & 16.4 & 6.7 & 2.2 & 510 \\
\hline \multicolumn{17}{|c|}{ Mouth of Spring Creek, 26 May 1999, $0.21 \mathrm{~m}^{3} / \mathrm{s}$} \\
\hline 1 & 0.6 & 0.2 & 2.2 & 15.7 & 34.7 & 34.5 & 12.0 & 0 & 1.6 & 35.0 & 27.1 & 24.4 & 11.2 & 2.0 & 0.2 & 810 \\
\hline 2 & 1.0 & 3.0 & 10.0 & 19.8 & 33.6 & 25.4 & 7.1 & 0 & 2.8 & 38.4 & 19.8 & 17.7 & 12.8 & 7.7 & 3.6 & 920 \\
\hline 3 & 6.1 & 10.3 & 11.6 & 12.2 & 28.3 & 26.0 & 3.7 & 1.8 & 2.5 & 42.5 & 18.0 & 18.9 & 13.5 & 5.9 & 1.2 & 810 \\
\hline 4 & 1.2 & 2.8 & 10.0 & 31.4 & 31.9 & 16.6 & 6.0 & 0 & 2.7 & 30.5 & 19.4 & 18.3 & 22.9 & 8.7 & 0.2 & 1100 \\
\hline \multicolumn{17}{|c|}{ Mouth of Spring Creek, 2 May $2000,0.047 \mathrm{~m}^{3} / \mathrm{s}$} \\
\hline 1 & 2.5 & 1.8 & 2.3 & 10.6 & 49.3 & 29.5 & 4.0 & 0 & 0.078 & 30.5 & 23.7 & 17.9 & 9.3 & 6.6 & 12.0 & 230 \\
\hline 2 & 6.4 & 13.7 & 18.5 & 26.6 & 24.9 & 9.5 & 0.4 & 0 & 0.33 & 18.0 & 13.5 & 23.8 & 26.6 & 18.1 & 0.0 & 400 \\
\hline 3 & 3.4 & 12.3 & 19.7 & 22.1 & 27.6 & 13.8 & 1.1 & 0 & 0.27 & 41.4 & 15.9 & 11.0 & 8.9 & 18.2 & 4.6 & 170 \\
\hline 4 & 5.0 & 15.2 & 20.5 & 23.0 & 24.4 & 11.4 & 0.5 & 0 & 0.24 & 21.2 & 11.3 & 21.3 & 31.1 & 11.6 & 3.5 & 410 \\
\hline
\end{tabular}

${ }^{2} 9.1$ percent is in the size class $64-128 \mathrm{~mm}$. 
Table 6.4. Summary of the particle-size distribution of replicate samples of bed and suspended load collected near the mouth of Buffalo Creek, 1997-2000

[This table contains raw values; bed load is all the sediment that is collected in a US BLH- 84 sampler, and suspended load is all the sediment collected by the pint-jar sampler with an isokinetic nozzle; dry masses have been used in calculating transport rates and concentrations; some sizes of bed load may have been in suspension depending upon the water discharge; $\mathrm{mm}$, millimeter; $\mathrm{kg} / \mathrm{s}$, kilogram per second; $\mathrm{mg} / \mathrm{L}$, milligram per liter; $\mathrm{m}^{3} / \mathrm{s}$, cubic meter per second; *, some organic material]

\begin{tabular}{|c|c|c|c|c|c|c|c|c|c|c|c|c|c|c|c|c|}
\hline \multirow[b]{2}{*}{$\begin{array}{l}\text { Rep- } \\
\text { licate }\end{array}$} & \multicolumn{9}{|c|}{ Bed load (percent of total) } & \multicolumn{7}{|c|}{ Suspended load (percent of total) } \\
\hline & $\begin{array}{c}0.250- \\
0.500 \\
\mathrm{~mm}\end{array}$ & $\begin{array}{c}0.500- \\
1.00 \\
\mathrm{~mm}\end{array}$ & $\begin{array}{l}1-2 \\
\mathrm{~mm}\end{array}$ & $\begin{array}{l}2-4 \\
\mathrm{~mm}\end{array}$ & $\begin{array}{l}\text { 4-8 } \\
\mathrm{mm}\end{array}$ & $\begin{array}{l}\text { 8-16 } \\
\mathrm{mm}\end{array}$ & $\begin{array}{c}16-32 \\
\mathrm{~mm}\end{array}$ & $\begin{array}{c}32-64 \\
\mathrm{~mm}\end{array}$ & $\begin{array}{l}\text { Trans- } \\
\text { port } \\
\text { rate } \\
(\mathrm{kg} / \mathrm{s})\end{array}$ & $\begin{array}{c}< \\
0.063 \\
\mathrm{~mm}\end{array}$ & $\begin{array}{c}0.063 \\
- \\
0.125 \\
\mathrm{~mm}\end{array}$ & $\begin{array}{c}0.125 \\
- \\
0.250 \\
\mathrm{~mm}\end{array}$ & $\begin{array}{c}0.250 \\
- \\
0.500 \\
\mathrm{~mm}\end{array}$ & $\begin{array}{c}0.500 \\
-1.00 \\
\mathrm{~mm}\end{array}$ & $\begin{array}{l}1-2 \\
\mathrm{~mm}\end{array}$ & $\begin{array}{c}\text { Concen- } \\
\text { tration } \\
(\mathrm{mg} / \mathrm{L})\end{array}$ \\
\hline
\end{tabular}

\begin{tabular}{|c|c|c|c|c|c|c|c|c|c|c|c|c|c|c|c|c|}
\hline \multicolumn{17}{|c|}{ Mouth of Buffalo Creek, 20 March $1997,0.18 \mathrm{~m}^{3} / \mathrm{s}$} \\
\hline 1 & 13.5 & 16.1 & 25.8 & 25.1 & 16.1 & 3.4 & 0 & 0 & 0.12 & \multicolumn{7}{|c|}{ no sample processed } \\
\hline 2 & 12.3 & 19.6 & 26.6 & 21.3 & 16.0 & 4.1 & 0 & 0 & 0.29 & \multicolumn{7}{|c|}{ no sample processed } \\
\hline 3 & 17.9 & 24.8 & 22.0 & 18.0 & 13.5 & 3.8 & 0 & 0 & 0.13 & \multicolumn{7}{|c|}{ no sample processed } \\
\hline \multicolumn{17}{|c|}{ Mouth of Buffalo Creek, $1 \mathrm{July} 1997,0.51 \mathrm{~m}^{3} / \mathrm{s}$} \\
\hline 1 & 17.9 & 14.1 & 21.4 & 20.9 & 16.7 & 8.4 & 0.7 & 0 & 0.33 & 59.7 & 11.5 & 20.2 & 8.6 & 0 & 0 & 150 \\
\hline 2 & 10.8 & 17.2 & 24.2 & 21.6 & 18.0 & 7.1 & 1.2 & 0 & 0.34 & 39.1 & 12.4 & 39.1 & 7.8 & 1.6 & 0 & 260 \\
\hline 3 & 8.8 & 11.2 & 18.3 & 26.2 & 26.9 & 8.7 & 0 & 0 & 0.45 & 41.1 & 19.6 & 28.8 & 7.8 & 2.6 & 0 & 300 \\
\hline 4 & 9.1 & 9.2 & 15.8 & 24.0 & 30.5 & 10.6 & 0.7 & 0 & 0.76 & 41.0 & 22.1 & 21.5 & 12.2 & 3.3 & 0 & 280 \\
\hline \multicolumn{17}{|c|}{ Mouth of Buffalo Creek, $14 \mathrm{July} 1997,0.27 \mathrm{~m}^{3} / \mathrm{s}$} \\
\hline 1 & 6.3 & 13.0 & 23.7 & 27.9 & 22.3 & 6.3 & 0.6 & 0 & 0.50 & 44.8 & 23.1 & 21.3 & 8.4 & 2.3 & 0 & 130 \\
\hline 2 & 8.7 & 15.1 & 21.5 & 25.4 & 21.5 & 6.7 & 1.1 & 0 & 0.50 & 34.8 & 25.4 & 26.9 & 10.6 & 2.3 & 0 & 180 \\
\hline 3 & 6.4 & 14.1 & 25.0 & 26.8 & 20.0 & 7.7 & 0 & 0 & 0.44 & 49.0 & 23.3 & 15.2 & 10.0 & 2.5 & $\mathbf{0}$ & 120 \\
\hline 4 & 9.3 & 19.0 & 21.2 & 21.4 & 22.9 & 6.1 & 0 & $\mathbf{0}$ & 0.59 & 43.3 & 22.6 & 20.2 & 11.6 & 2.3 & 0 & 130 \\
\hline \multicolumn{17}{|c|}{$480 \mathrm{~m}$ upstream from the Mouth of Buffalo Creek, $14 \mathrm{July} 1997,0.25 \mathrm{~m}^{3} / \mathrm{s}$} \\
\hline 1 & 4.5 & 12.8 & 22.3 & 28.1 & 25.4 & 6.6 & 0.3 & 0 & 0.59 & 40.0 & 18.4 & 21.7 & 15.6 & 4.4 & 0 & 150 \\
\hline 2 & 6.5 & 13.3 & 19.3 & 25.6 & 25.4 & 9.2 & 0.7 & 0 & 0.57 & 37.7 & 25.2 & 21.6 & 10.0 & 5.5 & 0 & 130 \\
\hline 3 & 4.4 & 13.0 & 21.5 & 28.1 & 25.4 & 7.0 & 0.6 & 0 & 0.53 & 33.3 & 16.9 & 26.6 & 17.3 & 5.8 & 0 & 180 \\
\hline 4 & 4.9 & 9.1 & 19.3 & 28.0 & 27.7 & 9.0 & 1.9 & 0 & 0.52 & 35.6 & 17.3 & 31.4 & 10.4 & 5.2 & 0 & 160 \\
\hline \multicolumn{17}{|c|}{ Mouth of Buffalo Creek, 19 August 1997, $0.44 \mathrm{~m}^{3} / \mathrm{s}$} \\
\hline 1 & 9.8 & 9.0 & 17.0 & 25.7 & 25.0 & 10.3 & 1.6 & 1.6 & 0.91 & 31.8 & 18.1 & 35.0 & 12.0 & 3.2 & 0 & 1000 \\
\hline 2 & 9.5 & 13.3 & 18.7 & 23.2 & 21.4 & 10.4 & 3.5 & 0 & 1.4 & 33.6 & 18.7 & 33.9 & 11.6 & 2.3 & 0 & 1200 \\
\hline 3 & 8.5 & 8.5 & 20.6 & 28.2 & 24.9 & 8.3 & 1.0 & 0 & 1.5 & 40.7 & 23.9 & 21.3 & 11.7 & 2.4 & 0 & 840 \\
\hline \multicolumn{17}{|c|}{ Mouth of Buffalo Creek, 1 September $1997,0.47 \mathrm{~m}^{3} / \mathrm{s}$} \\
\hline 1 & 11.8 & 12.6 & 17.9 & 21.4 & 24.6 & 10.0 & 1.6 & 0 & 1.7 & 44.1 & 19.0 & 16.2 & 16.8 & 3.9 & 0 & 2500 \\
\hline 2 & 8.8 & 13.6 & 21.0 & 25.5 & 22.3 & 7.2 & 1.6 & 0 & 2.7 & 40.0 & 11.4 & 34.3 & 11.3 & 3.1 & 0 & 2700 \\
\hline 3 & 16.1 & 19.1 & 21.4 & 18.4 & 18.6 & 5.9 & 0.5 & 0 & 1.6 & 42.1 & 22.4 & 19.3 & 12.1 & 4.2 & 0 & 2800 \\
\hline 4 & 8.7 & 11.5 & 19.4 & 29.8 & 23.1 & 7.5 & 0.0 & 0 & 2.2 & 39.2 & 20.7 & 15.7 & 14.6 & 6.7 & 3.1 & 3000 \\
\hline \multicolumn{17}{|c|}{ Mouth of Buffalo Creek, 3 November $1997,0.62 \mathrm{~m}^{3} / \mathrm{s}$-morning } \\
\hline 1 & 9.4 & 13.7 & 19.2 & 23.6 & 22.3 & 9.9 & 1.9 & 0 & 3.1 & 34.6 & 21.3 & 32.4 & 10.0 & 1.7 & 0 & 640 \\
\hline 2 & 7.5 & 9.7 & 18.5 & 27.4 & 25.2 & 9.9 & 1.9 & 0 & 2.4 & 21.7 & 13.1 & 45.8 & 17.1 & *2.2 & 0 & 750 \\
\hline \multicolumn{17}{|c|}{ Mouth of Buffalo Creek, 3 November $1997,0.62 \mathrm{~m}^{3} / \mathrm{s}$-afternoon } \\
\hline 1 & 7.9 & 9.1 & 15.2 & 28.7 & 24.7 & 12.5 & 1.9 & 0 & 3.1 & 29.6 & 20.8 & 27.8 & 19.0 & *2.7 & 0 & 660 \\
\hline 2 & 9.4 & 16.2 & 20.8 & 22.5 & 20.6 & 9.7 & 0.7 & 0 & 2.9 & 24.1 & 15.5 & 27.5 & 26.8 & 6.0 & 0.1 & 980 \\
\hline 3 & 8.6 & 14.6 & 23.5 & 23.8 & 19.2 & 8.9 & 1.3 & 0 & 3.9 & 24.1 & 20.6 & 28.2 & 22.2 & $* 4.9$ & 0 & 1000 \\
\hline 4 & 9.8 & 9.1 & 15.8 & 25.5 & 27.7 & 11.4 & 0.8 & 0 & 3.3 & \multicolumn{7}{|c|}{ no usable data } \\
\hline
\end{tabular}


Table 6.4. (Continued) Summary of the particle-size distribution of replicate samples of bed and suspended load collected near the mouth of Buffalo Creek, 1997-2000

\begin{tabular}{|c|c|c|c|c|c|c|c|c|c|c|c|c|c|c|c|c|}
\hline \multirow[b]{2}{*}{$\begin{array}{l}\text { Rep- } \\
\text { licate }\end{array}$} & \multicolumn{9}{|c|}{ Bed load (percent of total) } & \multicolumn{7}{|c|}{ Suspended load (percent of total) } \\
\hline & $\begin{array}{c}0.250- \\
0.500 \\
\mathrm{~mm}\end{array}$ & $\begin{array}{c}0.500- \\
1.00 \\
\mathrm{~mm}\end{array}$ & $\begin{array}{l}1-2 \\
\mathrm{~mm}\end{array}$ & $\begin{array}{l}2-4 \\
\mathrm{~mm}\end{array}$ & $\begin{array}{l}4-8 \\
\mathrm{~mm}\end{array}$ & $\begin{array}{l}8-16 \\
\mathrm{~mm}\end{array}$ & $\begin{array}{c}16-32 \\
\mathrm{~mm}\end{array}$ & $\begin{array}{c}32-64 \\
\mathrm{~mm}\end{array}$ & $\begin{array}{c}\text { Trans- } \\
\text { port } \\
\text { rate } \\
(\mathrm{kg} / \mathrm{s})\end{array}$ & $\begin{array}{c}< \\
0.063 \\
\mathbf{m m}\end{array}$ & $\begin{array}{c}0.063 \\
- \\
0.125 \\
\mathrm{~mm}\end{array}$ & $\begin{array}{c}0.125 \\
\mid- \\
0.250 \\
\mathrm{~mm}\end{array}$ & $\begin{array}{c}0.250 \\
- \\
0.500 \\
\mathrm{~mm}\end{array}$ & $\begin{array}{c}0.500 \\
-1.00 \\
\mathrm{~mm}\end{array}$ & $\begin{array}{l}1-2 \\
\mathrm{~mm}\end{array}$ & $\begin{array}{c}\text { Concen- } \\
\text { tration } \\
(\mathrm{mg} / \mathrm{L})\end{array}$ \\
\hline \multicolumn{17}{|c|}{ Mouth of Buffalo Creek, 7 November $1997,0.87 \mathrm{~m}^{3} / \mathrm{s}$} \\
\hline 1 & 7.4 & 10.9 & 17.0 & 25.4 & 28.4 & 10.9 & 0.0 & $\mathbf{0}$ & 3.5 & 22.2 & 17.6 & 26.3 & 23.2 & 10.8 & 0 & 860 \\
\hline 2 & 4.5 & 7.9 & 21.2 & 31.9 & 25.4 & 7.9 & 1.1 & $\mathbf{0}$ & 3.3 & 26.5 & 17.1 & 31.3 & 18.8 & 6.3 & 0 & 870 \\
\hline 3 & 13.1 & 15.6 & 19.5 & 22.2 & 20.3 & 8.7 & 0.6 & 0 & 3.1 & 22.1 & 12.2 & 29.4 & 23.1 & 13.3 & $\mathbf{0}$ & 970 \\
\hline 4 & 4.1 & 7.1 & 19.2 & 28.8 & 30.2 & 10.4 & 0.2 & 0 & 3.6 & 21.5 & 14.8 & 25.8 & 25.6 & 12.3 & 0 & 1100 \\
\hline \multicolumn{17}{|c|}{ Mouth of Buffalo Creek, 9 May 1998, $2.1 \mathrm{~m}^{3} / \mathrm{s}$} \\
\hline 1 & 11.9 & 18.0 & 21.9 & 21.8 & 18.2 & 7.4 & 0.7 & 0 & 8.9 & 22.0 & 16.6 & 25.8 & 22.2 & 7.0 & 6.5 & 763 \\
\hline 2 & 8.9 & 12.9 & 16.4 & 21.8 & 27.8 & 11.2 & 0.9 & 0 & 7.8 & 25.6 & 18.6 & 24.9 & 25.6 & 4.3 & 1.0 & 720 \\
\hline 3 & 9.4 & 13.6 & 19.2 & 21.0 & 24.0 & 9.6 & 3.3 & 0 & 9.7 & 24.1 & 19.0 & 31.1 & 18.8 & 5.0 & 2.0 & 670 \\
\hline 4 & 8.8 & 16.9 & 22.1 & 22.3 & 21.9 & 7.0 & 1.0 & 0 & 9.4 & 25.6 & 16.0 & 26.3 & 23.2 & 7.6 & 1.3 & 870 \\
\hline \multicolumn{17}{|c|}{$480 \mathrm{~m}$ upstream from the Mouth of Buffalo Creek, 9 May $1998,2.1 \mathrm{~m}^{3} / \mathrm{s}$} \\
\hline 1 & 6.8 & 13.9 & 21.0 & 24.9 & 23.2 & 9.6 & 0.7 & 0 & 17 & 13.7 & 11.3 & 23.5 & 33.8 & 12.2 & 5.4 & 1100 \\
\hline 2 & 6.7 & 14.7 & 23.6 & 25.1 & 20.2 & 7.5 & 1.0 & 1.2 & 18 & 8.3 & 7.5 & 20.4 & 39.0 & 20.5 & 4.3 & 1600 \\
\hline 3 & 4.7 & 8.2 & 17.3 & 25.9 & 31.2 & 10.4 & 2.3 & 0 & 17 & 12.7 & 9.9 & 15.8 & 45.6 & 14.1 & 1.8 & 970 \\
\hline 4 & 8.0 & 16.5 & 22.8 & 19.1 & 23.3 & 8.7 & 1.6 & 0 & 16 & 18.2 & 9.3 & 28.9 & 30.0 & 10.1 & 3.6 & 850 \\
\hline \multicolumn{17}{|c|}{ Mouth of Buffalo Creek, 22 July 1998, $0.62 \mathrm{~m}^{3} / \mathrm{s}$} \\
\hline 1 & 18.2 & 11.3 & 15.6 & 25.1 & 25.1 & 4.7 & 0 & 0 & 0.027 & 41.2 & 14.2 & 8.0 & 12.3 & 24.3 & 0 & 80 \\
\hline 2 & 16.2 & 11.6 & 14.4 & 24.3 & 24.8 & 8.6 & 0 & 0 & 0.014 & 55.6 & 18.2 & 16.8 & 9.4 & 0 & 0 & 26 \\
\hline 3 & 15.6 & 9.6 & 13.2 & 21.8 & 27.6 & 8.6 & 3.5 & 0 & 0.034 & 59.1 & 17.4 & 17.0 & 6.6 & 0 & 0 & 15 \\
\hline 4 & 15.7 & 21.5 & 20.3 & 17.6 & 19.5 & 5.4 & 0 & 0 & 0.031 & 58.1 & 21.9 & 15.8 & 4.2 & 0 & 0 & 16 \\
\hline \multicolumn{17}{|c|}{$480 \mathrm{~m}$ upstream from the mouth of Buffalo Creek, 7 August $1998,1.0 \mathrm{~m}^{3} / \mathrm{s}$} \\
\hline 1 & 12.8 & 15.1 & 23.3 & 22.8 & 18.8 & 6.9 & 0.2 & 0 & 5.8 & 26.7 & 14.9 & 28.5 & 25.8 & 3.8 & 0.4 & 1500 \\
\hline 2 & 6.6 & 13.0 & 26.3 & 27.2 & 19.9 & 6.7 & 0.4 & 0 & 7.3 & 34.0 & 18.1 & 23.4 & 19.9 & 3.9 & 0.6 & 1500 \\
\hline 3 & 13.4 & 20.4 & 26.1 & 17.8 & 15.7 & 5.9 & 0.7 & 0 & 6.7 & 21.7 & 17.8 & 27.5 & 27.9 & 4.4 & 0.7 & 1500 \\
\hline 4 & 12.2 & 16.8 & 22.1 & 22.2 & 19.3 & 6.9 & 0.4 & 0 & 6.9 & 20.8 & 12.5 & 27.9 & 29.6 & 8.8 & 0.3 & 1900 \\
\hline \multicolumn{17}{|c|}{ Mouth of Buffalo Creek, 26 May 1999, $5.2 \mathrm{~m}^{3} / \mathrm{s}$} \\
\hline 1 & 7.1 & 13.1 & 23.1 & 30.0 & 20.2 & 5.8 & 0.6 & 0 & 28 & 28.8 & 15.9 & 22.7 & 20.4 & 9.2 & 3.1 & 1600 \\
\hline 2 & 9.7 & 14.1 & 17.3 & 21.7 & 23.8 & 11.6 & 1.9 & 0 & 22 & 31.4 & 18.0 & 19.6 & 19.5 & 8.7 & 2.8 & 1600 \\
\hline 3 & 7.7 & 13.6 & 19.8 & 25.3 & 22.8 & 9.3 & 1.6 & 0 & 23 & 34.6 & 7.1 & 33.6 & 19.5 & 3.7 & 1.5 & 1400 \\
\hline 4 & 6.4 & 12.6 & 20.4 & 26.7 & 24.5 & 8.0 & 1.3 & 0 & 24 & 35.9 & 18.4 & 19.8 & 15.3 & 8.6 & 1.9 & 1400 \\
\hline \multicolumn{17}{|c|}{ Mouth of Buffalo Creek, 4 June $2000,0.29 \mathrm{~m}^{3} / \mathrm{s}$} \\
\hline 1 & 8.4 & 10.4 & 17.0 & 28.8 & 28.8 & 6.7 & 0 & 0 & 0.0070 & 45.3 & 20.8 & 20.5 & 8.2 & 5.2 & 0 & 21 \\
\hline 2 & 9.6 & 18.8 & 28.5 & 30.4 & 11.7 & 1.0 & 0 & 0 & 0.0051 & 41.0 & 23.0 & 19.6 & 13.8 & 2.6 & 0 & 14 \\
\hline 3 & 6.6 & 12.8 & 20.8 & 26.6 & 26.3 & 7.0 & 0 & 0 & 0.0041 & 32.5 & 10.7 & 20.2 & 23.0 & 13.5 & 0 & 4.2 \\
\hline
\end{tabular}




\section{Table 6.5. Summary of sediment transport measurements in Spring Creek, 1997-2000}

$\left[\tau\right.$, total bed shear stress; $u^{*}$, mean shear velocity; $D^{*}$ was used to separate bed load from suspended load and, therefore, the average sediment transport and concentration values may not agree with values in table 6.3 for the raw data; median diameter, $D_{50}$, was calculated by linear interpolation of the average cumulative distribution of the replicates; value given after \pm is the $95 \%$ confidence limits; $\mathrm{m}$, meter; $\mathrm{m} / \mathrm{s}$, meter per second; $\mathrm{m}^{3} / \mathrm{s}$, cubic meter per second; $\mathrm{N} / \mathrm{m}^{2}$, newton per square meter; $\mathrm{kg} / \mathrm{s}$, kilogram per second; $\mathrm{kg} / \mathrm{s} / \mathrm{m}$, kilogram per second per meter; $\mathrm{mg} / \mathrm{L}$, milligram per liter; mm, millimeter]

\begin{tabular}{|c|c|c|c|c|c|c|c|c|c|c|c|c|c|c|}
\hline \multirow{3}{*}{$\begin{array}{c}\text { Mean } \\
\text { depth } \\
\text { (m) }\end{array}$} & \multirow{3}{*}{$\begin{array}{l}\text { Width } \\
\text { (m) }\end{array}$} & \multirow{3}{*}{ Slope } & \multirow{3}{*}{$\begin{array}{c}\text { Mean } \\
\text { velo- } \\
\text { city } \\
(\mathrm{m} / \mathrm{s})\end{array}$} & \multirow{3}{*}{$\begin{array}{l}\text { Dis- } \\
\text { charge } \\
\left(\mathrm{m}^{3} / \mathrm{s}\right)\end{array}$} & \multirow{3}{*}{$\begin{array}{c}\tau^{\mathrm{a}} \\
\left(\mathrm{N} / \mathrm{m}^{2}\right)\end{array}$} & \multirow{3}{*}{$\begin{array}{l}u^{*^{a}} \\
(\mathrm{~m} / \mathrm{s})\end{array}$} & \multicolumn{5}{|c|}{ Sediment transport } & \multicolumn{3}{|c|}{ Particle size } \\
\hline & & & & & & & \multirow{2}{*}{\multicolumn{2}{|c|}{$\begin{array}{c}\begin{array}{c}\text { Mean } \\
\text { bed load }\end{array} \\
(\mathrm{kg} / \mathrm{s} / \mathrm{m})(\mathrm{kg} / \mathrm{s}) \\
\end{array}$}} & \multicolumn{2}{|c|}{$\begin{array}{c}\text { Mean } \\
\text { suspended load }\end{array}$} & \multirow{2}{*}{$\begin{array}{c}\text { Fraction } \\
<0.063 \\
\mathbf{m m} \\
(\mathrm{kg} / \mathrm{s})\end{array}$} & \multirow{2}{*}{$\begin{array}{l}D^{* \mathbf{b}} \\
(\mathbf{m m})\end{array}$} & \multirow{2}{*}{$\begin{array}{c}D_{50} \\
\text { Bed } \\
\text { load } \\
\\
(\mathbf{m m}) \\
\end{array}$} & \multirow{2}{*}{$\begin{array}{c}D_{50} \\
\text { Suspended } \\
\text { load } \\
\text { (mm) } \\
\end{array}$} \\
\hline & & & & & & & & & $(\mathrm{mg} / \mathrm{L})$ & $\overline{(\mathrm{kg} / \mathrm{s})}$ & & & & \\
\hline \multicolumn{15}{|c|}{1997} \\
\hline \multicolumn{15}{|c|}{ Wooden Parshall Flume at Mouth of Spring Creek, 28 June 1997} \\
\hline \multirow[t]{2}{*}{0.064} & 0.61 & $0.04^{\mathrm{c}}$ & 0.41 & $0.016^{\mathrm{c}}$ & 25 & 0.16 & 0.12 & 0.076 & 1500 & 0.025 & 0.004 & 0.45 & 3.7 & 0.10 \\
\hline & & & & & & & \pm 0.05 & \pm 0.032 & \pm 4300 & \pm 0.069 & \pm 0.006 & & & \\
\hline \multicolumn{15}{|c|}{ Wooden Parshall Flume at Mouth of Spring Creek, 2 July 1997} \\
\hline \multirow[t]{2}{*}{0.034} & 0.61 & $0.04^{\mathrm{c}}$ & 0.37 & $0.0078^{\mathrm{c}}$ & 13 & 0.12 & 0.046 & 0.028 & 34 & 0.00027 & 0.00011 & $0.39^{e}$ & 4.8 & 0.074 \\
\hline & & & & & & & \pm 0.020 & \pm 0.012 & \pm 35 & \pm 0.00027 & \pm 0.00027 & & & \\
\hline \multicolumn{15}{|c|}{ Wooden Parshall Flume at Mouth of Spring Creek, 11 July $1997^{\mathrm{f}}$} \\
\hline \multirow[t]{2}{*}{0.021} & 0.61 & 0.026 & 0.28 & $0.0036^{d}$ & 5.4 & 0.073 & 0.00030 & 0.00018 & 61 & 0.00022 & 0.00017 & 0.31 & 3.1 & $<0.063$ \\
\hline & & & & & & & \pm 0.00041 & \pm 0.00025 & \pm 86 & \pm 0.00031 & \pm 0.00026 & & & \\
\hline \multicolumn{15}{|c|}{ Grab sample collected at the gage on falling limb of flash flood, 29 July 1997} \\
\hline 0.33 & 8.7 & 0.041 & 1.7 & 5.0 & 130 & 0.36 & nos & mple & 9600 & 48 & 34 & & no anal & lysis \\
\hline & & & & Woo & den Pars & all Flu & le at Mou & of Sprin & Creek, 3 A & lugust 199 & & & & \\
\hline 0.067 & 0.61 & 0.030 & 0.54 & $0.022^{\mathrm{d}}$ & 20 & 0.14 & 0.31 & 0.19 & 1700 & 0.037 & 0.017 & 0.42 & 4.8 & 0.078 \\
\hline & & & & & . & & \pm 0.20 & \pm 0.12 & \pm 280 & \pm 0.0062 & \pm 0.006 & & & \\
\hline & & & & Woo & den Pars & hall Flu & le at Mou & h of Sprin & Creek, 5 & lugust 199 & & & & \\
\hline 0.089 & 0.61 & 0.032 & 0.63 & $0.034^{\mathrm{d}}$ & 28 & 0.17 & 0.95 & 0.58 & 5800 & 0.20 & 0.094 & 0.47 & 7.3 & 0.065 \\
\hline & & & & & & & \pm 0.38 & \pm 0.23 & \pm 920 & \pm 0.031 & \pm 0.018 & & & \\
\hline & & & & & & outh of & pring Cre & k, $15 \mathrm{Sept}$ & ember 1997 & & & & & \\
\hline 0.048 & $1.30^{\mathrm{g}}$ & 0.032 & 0.61 & 0.038 & 15 & 0.12 & 0.11 & 0.14 & 400 & 0.016 & 0.0074 & 0.39 & 4.6 & 0.076 \\
\hline & & & & & & & \pm 0.038 & \pm 0.05 & \pm 66 & \pm 0.0026 & \pm 0.0019 & & & \\
\hline & & & & & & Mouth C & Spring C & eek, 8 Oct & ber 1997 & & & & & \\
\hline 0.041 & 0.85 & 0.027 & 0.66 & 0.023 & 11 & 0.10 & 0.093 & 0.079 & 310 & 0.0071 & 0.0021 & 0.36 & 4.1 & 0.13 \\
\hline & & & & & & & \pm 0.094 & \pm 0.080 & \pm 180 & \pm 0.0041 & \pm 0.00018 & & & \\
\hline & & & & & & & & 98 & & & & & & \\
\hline & & & & Mol & uth of Sp & ring $\mathrm{Cr}$ & k-Flume & uilt from & boulders, 2 & 1 May 199 & & & & \\
\hline 0.050 & 2.7 & 0.030 & 1.2 & 0.16 & 15 & 0.12 & $0.96^{\mathrm{h}}$ & 1.2 & 950 & 0.15 & 0.060 & 0.39 & 6.1 & 0.11 \\
\hline & & & & & & & \pm 0.38 & \pm 0.46 & \pm 190 & \pm 0.030 & \pm 0.023 & & & \\
\hline & & & & Mou & th of $S p$ & ing Cre & k-Flume & uilt from & oulders, 2 & 6 June 199 & & & & \\
\hline 0.047 & $2.0^{\mathrm{i}}$ & 0.025 & 0.79 & 0.074 & 12 & 0.11 & $0.32^{\mathrm{h}}$ & 0.40 & 430 & 0.032 & 0.013 & 0.38 & 5.4 & 0.10 \\
\hline & & & & & & & \pm 0.10 & \pm 0.12 & \pm 90 & \pm 0.0067 & \pm 0.0040 & & & \\
\hline & & & & & At & faging s & e on Spri & g Creek, 5 & August 199 & & & & & \\
\hline 0.048 & 2.7 & 0.034 & 1.1 & 0.14 & 16 & 0.13 & 1.2 & 3.3 & 1900 & 0.27 & 0.095 & 0.41 & 5.5 & 0.12 \\
\hline & & & & & & & \pm 0.59 & \pm 1.6 & \pm 960 & \pm 0.13 & \pm 0.031 & & & \\
\hline
\end{tabular}




\section{Table 6.5. (Continued) Summary of sediment transport measurements in Spring Creek, 1997- 2000}

\begin{tabular}{|c|c|c|c|c|c|c|c|c|c|c|c|c|c|}
\hline \multirow{3}{*}{$\begin{array}{c}\text { Mean } \\
\text { depth } \\
\text { (m) }\end{array}$} & \multirow{3}{*}{$\begin{array}{c}\text { Width } \\
\text { (m) }\end{array}$} & \multirow{3}{*}{ Slope } & \multirow{3}{*}{$\begin{array}{l}\text { Mean } \\
\text { velo- } \\
\text { city } \\
(\mathrm{m} / \mathrm{s})\end{array}$} & \multirow{3}{*}{$\begin{array}{c}\text { Dis- } \\
\text { charge } \\
\left(\mathrm{m}^{3} / \mathrm{s}\right)\end{array}$} & \multirow{3}{*}{$\begin{array}{c}\tau^{a} \\
\left(N / m^{2}\right)\end{array}$} & \multirow{3}{*}{$\begin{array}{c}u^{*^{2}} \\
(\mathrm{~m} / \mathrm{s})\end{array}$} & \multicolumn{4}{|c|}{ Sediment transport } & \multicolumn{3}{|c|}{ Particle size } \\
\hline & & & & & & & \multirow{2}{*}{$\begin{array}{c}\begin{array}{c}\text { Mean } \\
\text { bed load }\end{array} \\
(\mathrm{kg} / \mathrm{s} / \mathrm{m})(\mathrm{kg} / \mathrm{s})\end{array}$} & \multicolumn{2}{|c|}{$\begin{array}{c}\text { Mean } \\
\text { suspended load }\end{array}$} & \multirow{2}{*}{$\begin{array}{c}\text { Fraction } \\
<0.063 \\
\text { mm } \\
(\mathbf{k g} / \mathbf{s})\end{array}$} & \multirow{2}{*}{$\begin{array}{l}D^{* \mathbf{b}} \\
(\mathbf{m m})\end{array}$} & \multirow{2}{*}{$\begin{array}{c}D_{50} \\
\text { Bed } \\
\text { load } \\
\\
(\mathrm{mm})\end{array}$} & \multirow{2}{*}{$\begin{array}{c}D_{50} \\
\text { Suspended } \\
\text { load } \\
\text { (mm) }\end{array}$} \\
\hline & & & & & & & & $\overline{(\mathrm{mg} / \mathrm{L})}$ & $\overline{(\mathrm{kg} / \mathrm{s})}$ & & & & \\
\hline \multicolumn{14}{|c|}{1999} \\
\hline \multicolumn{14}{|c|}{ Mouth of Spring Creek, 15 May 1999} \\
\hline \multirow[t]{3}{*}{0.065} & 1.4 & 0.027 & 1.1 & 0.10 & 17 & 0.13 & 0.71 & 620 & 0.062 & 0.020 & 0.41 & 5.1 & 0.13 \\
\hline & & & & & & & \pm 0.63 & \pm 150 & \pm 0.015 & \pm 0.010 & & & \\
\hline & & & & & & \multicolumn{4}{|c|}{ Mouth of Spring Creek, 26 May 1999} & & & & \\
\hline \multirow[t]{2}{*}{0.070} & 2.0 & 0.034 & 1.5 & 0.21 & 23 & 0.15 & 2.4 & 960 & 0.20 & 0.069 & 0.44 & 5.9 & 0.11 \\
\hline & & & & & & & \pm 0.44 & \pm 490 & \pm 0.10 & \pm 0.011 & & & \\
\hline \multicolumn{14}{|c|}{2000} \\
\hline & & & & & & Mouth & of Spring Creek, 2 N & ay 2000 & & & & & \\
\hline \multirow[t]{2}{*}{0.058} & 0.95 & 0.026 & 0.85 & 0.047 & 15 & 0.12 & 0.23 & 380 & 0.018 & 0.0035 & 0.39 & 3.5 & 0.26 \\
\hline & & & & & & & \pm 0.18 & \pm 60 & \pm 0.0028 & \pm 0.00066 & & & \\
\hline
\end{tabular}

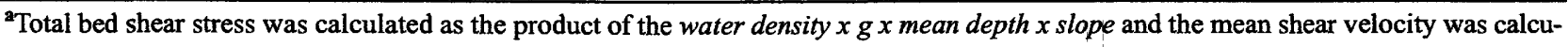
lated as $u^{*}=\sqrt{g \cdot m e a n \cdot \text { depth } \cdot \text { slope }}$, where $g=9.8 \mathrm{~m} / \mathrm{s}^{2}$.

${ }^{\mathrm{b}} D^{*}$ is the particle diameter for a fall velocity equal to $u^{*}$ assuming Stoke's or viscous settling $\left(D^{*}=\sqrt{\frac{18 u^{*} \rho v}{\left(\rho_{s}-\rho\right) \cdot g}}\right.$, where $v=0.0116 \cdot \mathrm{cm}^{2} / \mathrm{s}$ for about $15^{\circ} \mathrm{C}, \mathrm{g}=9.8 \cdot \mathrm{m} / \mathrm{s}^{2}$, and $\left.\left(\rho_{s}-\rho\right) / \rho=1.65\right)$.

${ }^{c}$ An estimated slope was used.

${ }^{\mathrm{d}}$ Discharges were determined from 2-ft Parshall Flume Table.

'Most of the $0.250-0.500 \mathrm{~mm}$ fraction of bed load should have been in the suspended load because $D^{*}=0.39 \mathrm{~mm}$. The amount of material in this size class was much greater than the smaller size class $(0.125-0.250 \mathrm{~mm})$ of the suspended load; therefore, the $0.250-0.500 \mathrm{~mm}$ fraction was grouped with the bed load.

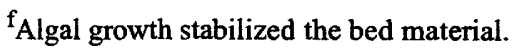

gThe mean depth for the discharge measurement was $0.046 \mathrm{~m}$ and the width was $1.40 \mathrm{~m}$.

${ }^{\mathrm{h}}$ Width of the moving bedload was $1.20 \mathrm{~m}$.

'The width of the moving bed load was $1.25 \mathrm{~m}$. 
Table 6.6. Summary of sediment transport measurements in Buffalo Creek, 1997-2000

[ $\tau$, total bed shear stress; $u^{*}$, mean shear velocity; $D^{*}$ was used to separate bed load from suspended load and, therefore, the average sediment transport and concentration values may not agree with values in table 6.4 for the raw data; median diameter, $D_{50}$, was calculated by linear interpolation of the average cumulative distribution of the replicates; value given after \pm is the $95 \%$ confidence limits; $\mathrm{m}$, meter; $\mathrm{m} / \mathrm{s}$, meter per second; $\mathrm{m}^{3} / \mathrm{s}$, cubic meter per second; $\mathrm{N} / \mathrm{m}^{2}$, newton per square meter; $\mathrm{kg} / \mathrm{s}$, kilogram per second; $\mathrm{kg} / \mathrm{s} / \mathrm{m}$, kilogram per second per meter; $\mathrm{mg} / \mathrm{L}$, milligram per liter; mm, millimeter]

\begin{tabular}{|c|c|c|c|c|c|c|c|c|c|c|c|c|}
\hline \multirow{4}{*}{$\begin{array}{c}\text { Mean } \\
\text { depth } \\
\text { (m) }\end{array}$} & \multirow{4}{*}{$\begin{array}{c}\text { Width } \\
\text { (m) }\end{array}$} & \multirow{4}{*}{ Slope } & \multirow{4}{*}{$\begin{array}{c}\text { Mean } \\
\text { velo- } \\
\text { city } \\
(\mathrm{m} / \mathrm{s})\end{array}$} & \multirow{4}{*}{$\begin{array}{c}\text { Dis- } \\
\text { charge } \\
\left(\mathrm{m}^{3} / \mathrm{s}\right)\end{array}$} & \multirow{4}{*}{$\begin{array}{c}\tau^{a} \\
\left(N / m^{2}\right)\end{array}$} & \multirow{4}{*}{$\begin{array}{c}u^{*^{\mathrm{a}}} \\
(\mathrm{m} / \mathrm{s})\end{array}$} & \multicolumn{3}{|c|}{ Sediment transport } & \multicolumn{3}{|c|}{ Particle size } \\
\hline & & & & & & & & & & & $D_{50}$ & $D_{50}$ \\
\hline & & & & & & & $\begin{array}{c}\text { Mean } \\
\text { bed load }\end{array}$ & $\begin{array}{c}\text { Mean } \\
\text { suspended load }\end{array}$ & \multirow{2}{*}{$\begin{array}{c}\text { Fraction } \\
<0.063 \\
\mathrm{~mm} \\
(\mathrm{~kg} / \mathrm{s})\end{array}$} & \multirow{2}{*}{$\begin{array}{l}D^{* \mathbf{b}} \\
(\mathbf{m m})\end{array}$} & $\begin{array}{c}\text { Bed } \\
\text { load }\end{array}$ & $\begin{array}{l}\text { Suspended } \\
\text { load }\end{array}$ \\
\hline & & & & & & & $(\mathrm{kg} / \mathrm{s} / \mathrm{m})(\mathrm{kg} / \mathrm{s})$ & $\begin{array}{ll}(\mathrm{mg} / \mathrm{L}) & (\mathrm{kg} / \mathrm{s})\end{array}$ & & & (mm) & (mm) \\
\hline
\end{tabular}

1997

$79 \mathrm{~m}$ upstream from the mouth of Buffalo Creek, 20 March 1997

\begin{tabular}{|c|c|c|c|c|c|c|c|c|c|c|c|c|c|c|}
\hline \multirow[t]{2}{*}{0.063} & 4.1 & 0.0093 & 0.68 & 0.18 & 5.7 & 0.076 & 0.044 & 0.18 & \multicolumn{3}{|c|}{ no sample } & 0.31 & 1.6 & - \\
\hline & & & & & & & \pm 0.054 & \pm 0.22 & & & & & & \\
\hline \multicolumn{15}{|c|}{79 m upstream from the mouth of Buffalo Creek, 1 July 1997} \\
\hline \multirow[t]{3}{*}{0.074} & 8.4 & 0.0093 & 0.82 & 0.51 & 6.7 & 0.082 & 0.056 & 0.47 & 220 & 0.11 & 0.055 & 0.33 & 2.7 & 0.067 \\
\hline & & & & & & & \pm 0.037 & \pm 0.31 & \pm 90 & \pm 0.046 & \pm 0.011 & & & \\
\hline & \multicolumn{14}{|c|}{79 m upstream from the mouth of Buffalo Creek, 14 July 1997} \\
\hline \multirow[t]{3}{*}{0.053} & 9.3 & 0.010 & 0.55 & 0.27 & 5.2 & 0.072 & 0.055 & 0.51 & 120 & 0.032 & 0.016 & 0.30 & 2.3 & 0.067 \\
\hline & & & & & & & \pm 0.012 & \pm 0.11 & \pm 41 & \pm 0.011 & \pm 0.0015 & & & \\
\hline & \multicolumn{14}{|c|}{$480 \mathrm{~m}$ upstream from the mouth of Buffalo Creek, 14 July 1997} \\
\hline \multirow[t]{3}{*}{0.064} & 5.6 & 0.011 & 0.69 & 0.25 & 6.9 & 0.083 & 0.11 & 0.55 & 130 & 0.032 & 0.014 & 0.33 & 2.9 & 0.076 \\
\hline & $5.2^{\mathrm{c}}$ & & & & & & \pm 0.01 & \pm 0.05 & \pm 20 & \pm 0.0050 & \pm 0.0019 & & & \\
\hline & \multicolumn{14}{|c|}{72 m upstream from the mouth of Buffalo Creek, 19 August 1997} \\
\hline \multirow[t]{3}{*}{0.070} & 7.3 & 0.011 & 0.86 & 0.44 & 7.5 & 0.087 & 0.21 & 1.3 & 870 & 0.38 & 0.16 & 0.33 & 2.9 & 0.089 \\
\hline & $6.2^{\mathrm{c}}$ & & & & & & \pm 0.12 & \pm 0.77 & \pm 380 & \pm 0.17 & \pm 0.035 & & & \\
\hline & \multicolumn{14}{|c|}{ about 90 m upstream from the mouth of Buffalo Creek, 1 September 1997} \\
\hline 0.096 & 5.0 & 0.013 & 0.98 & 0.47 & 12 & 0.11 & 0.36 & 1.8 & 2700 & 1.3 & 0.53 & 0.38 & 2.9 & 0.090 \\
\hline & & & & & & & \pm 0.16 & \pm 0.82 & \pm 370 & \pm 0.17 & \pm 0.038 & & & \\
\hline
\end{tabular}

about 90 m upstream from the mouth of Buffalo Creek, 3 November 1997; measurement made in the morning; 2 replicates

$\begin{array}{rrrrrrrrrrrrrrrrr}0.094 & 6.3 & 0.015 & 1.03 & 0.62 & 14 & 0.12 & 0.40 & 2.5 & 970 & 0.60 & 0.12 & 0.39 & 3.2 & 0.20 \\ & & & & & & & & \pm 0.60 & \pm 3.8 & \pm 850 & \pm 0.53 & \pm 0.24 & & & & \end{array}$

about $90 \mathrm{~m}$ upstream from the mouth of Buffalo Creek, 3 November 1997; measurement made in the afternoon; 4 replicates

\begin{tabular}{|c|c|c|c|c|c|c|c|c|c|c|c|c|c|c|}
\hline \multirow[t]{2}{*}{0.085} & 8.0 & 0.013 & 0.91 & 0.62 & 11 & 0.10 & 0.30 & 2.4 & 1000 & 0.62 & 0.14 & 0.36 & 3.1 & 0.19 \\
\hline & & & & & & & \pm 0.12 & \pm 0.95 & \pm 130 & \pm 0.081 & \pm 0.038 & & & \\
\hline \multicolumn{15}{|c|}{ 79 m upstream from the mouth of Buffalo Creek; 7 November 1997} \\
\hline \multirow[t]{2}{*}{0.11} & 7.5 & 0.015 & 1.0 & 0.87 & 16 & 0.13 & 0.41 & 3.1 & 900 & 0.78 & 0.19 & 0.41 & 3.2 & 0.17 \\
\hline & & & & & & & \pm 0.076 & \pm 0.57 & \pm 210 & \pm 0.18 & \pm 0.025 & & & \\
\hline
\end{tabular}


Table 6.6. (Continued) Summary of sediment transport measurements in Buffalo Creek, 19972000

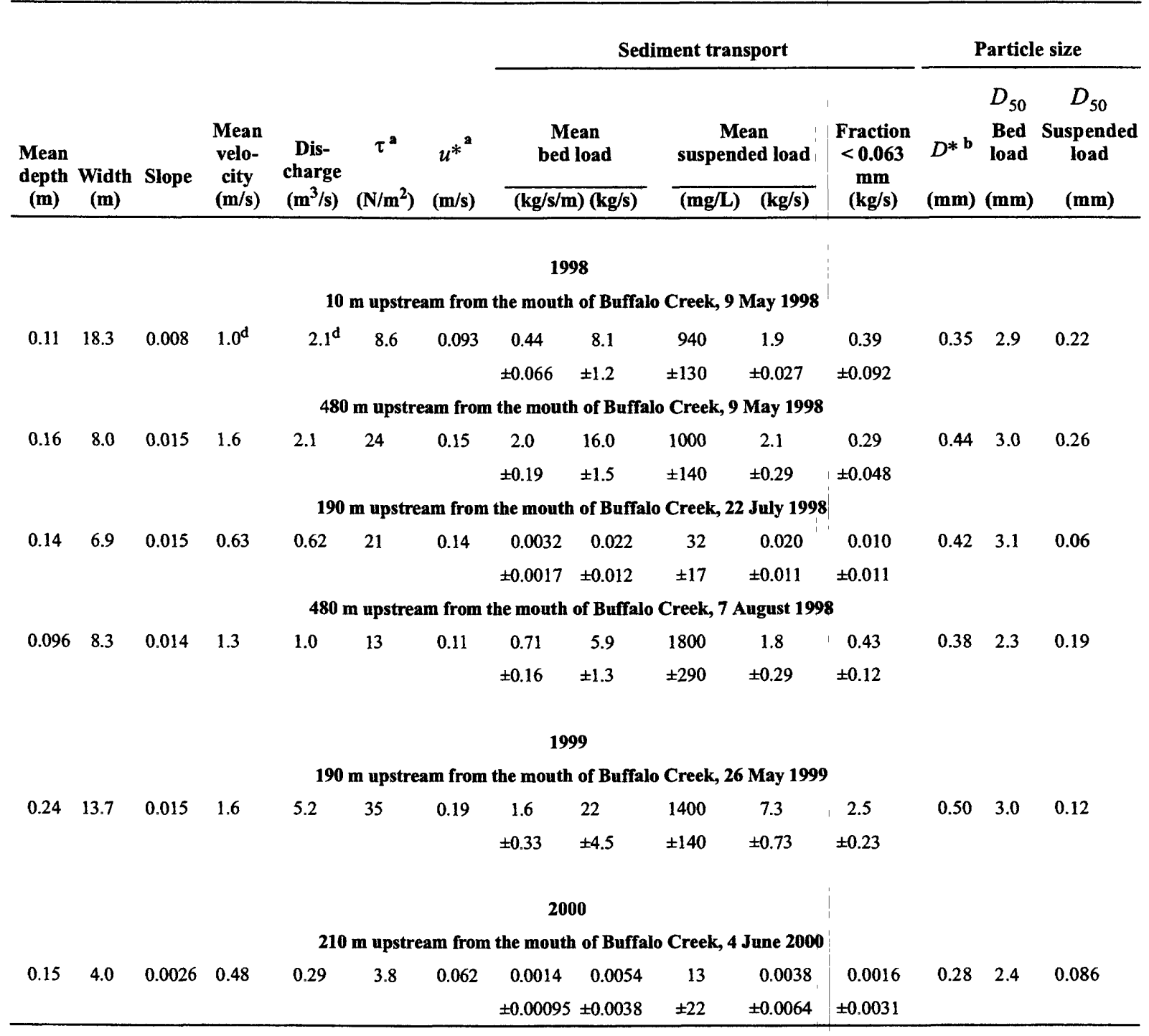

${ }^{2}$ Total shear stress was calculated as the product of the water density $x \mathrm{~g} x$ mean depth $x$ slope and the mean shear velocity was calculated as $u^{*}=\sqrt{g \cdot \text { mean } \cdot \text { depth } \cdot \text { slope }}$, where $g=9.8 \mathrm{~m} / \mathrm{s}^{2}$.

${ }^{\mathrm{b}} D^{*}$ is the particle diameter for a fall velocity equal to $u^{*}$ assuming Stoke's or viscous settling $\left(D^{*}=\sqrt{\frac{18 u^{*} \rho v}{\left(\rho_{s}-\rho\right) \cdot g}}\right.$, where $v=0.0116 \cdot \mathrm{cm}^{2} / \mathrm{s}$ for about $15^{\circ} \mathrm{C}, g=9.8 \cdot \mathrm{m} / \mathrm{s}^{2}$, and $\left.\left(\rho_{s}-\rho\right) / \rho=1.65\right)$.

${ }^{\mathrm{c}}$ This is the width for the moving bed load.

dDischarge was estimated to be the same as 9 May 1998 at $480 \mathrm{~m}$ upstream fom mouth of Buffalo Creek. 
Table 6.7. Threshold data for bed-load movement in Spring Creek

[Dimensionless shear stress, $\tau^{*}=\tau /\left(g \cdot\left(\rho_{s}-\rho\right) \cdot D_{b}\right)$; where $\tau$ is the total bed shear stress, $g$ is $9.8 \mathrm{~m} / \mathrm{s}^{2}, \rho_{s}$ is assumed to be $2,650 \mathrm{~kg} / \mathrm{m}^{3}, \rho$ is density of water, and $D_{b}$ is the median diameter of the largest class size moved; critical unit discharge for initiation of motion is greater than the mean discharge for calculating sediment transport in table $6.9 ; \mathrm{m}$, meter; $\mathrm{m}^{3} / \mathrm{s} / \mathrm{m}$, cubic meter per second per meter; $\mathrm{N} / \mathrm{m}^{2}$, newton per square meter]

\begin{tabular}{|c|c|c|c|c|c|c|c|}
\hline Date & $\begin{array}{c}\text { Mean depth } \\
h \\
\text { (m) }\end{array}$ & $\begin{array}{l}\text { Unit discharge } \\
\left(\mathrm{m}^{3} / \mathrm{s} / \mathrm{m}\right)\end{array}$ & $\begin{array}{c}\text { Total bed shear } \\
\text { stress } \\
\tau \\
\left(\mathrm{N} / \mathrm{m}^{2}\right)\end{array}$ & $\begin{array}{c}\text { Dimensionless } \\
\text { shear stress } \\
\tau^{*}\end{array}$ & $\begin{array}{l}D_{b} \\
\text { (m) }\end{array}$ & $\begin{array}{l}\text { Percent of } \\
\text { total }\end{array}$ & $\frac{D_{b}}{h}$ \\
\hline \multicolumn{8}{|c|}{1997} \\
\hline 28 June & 0.064 & 0.026 & 25 & 0.070 & 0.022 & 1.5 & 0.34 \\
\hline 2 July & 0.034 & 0.013 & 13 & 0.037 & 0.022 & 2.9 & 0.65 \\
\hline 11 July $^{\mathrm{a}}$ & 0.021 & 0.0059 & 5.4 & 0.030 & 0.011 & 3.4 & 0.52 \\
\hline 3 August & 0.067 & 0.036 & 20 & 0.027 & 0.045 & 0.2 & 0.67 \\
\hline 5 August $^{b}$ & 0.089 & 0.056 & 28 & 0.019 & 0.091 & 2.3 & 1.0 \\
\hline 15 Sept. & 0.048 & 0.029 & 15 & 0.042 & 0.022 & 7.0 & 0.46 \\
\hline 9 October & 0.041 & 0.027 & 11 & 0.031 & 0.022 & 3.8 & 0.54 \\
\hline \multicolumn{8}{|c|}{1998} \\
\hline 21 May & 0.050 & 0.059 & 15 & 0.021 & 0.045 & 3.2 & 0.90 \\
\hline 26 June & 0.047 & 0.037 & 12 & 0.034 & 0.022 & 2.7 & 0.47 \\
\hline 9 July $^{\mathrm{c}}$ & 1.2 & 4.6 & 470 & 0.029 & 1. & $<1.0$ & 0.83 \\
\hline 5 August & 0.048 & 0.052 & 16 & 0.045 & 0.022 & 5.8 & 0.46 \\
\hline \multicolumn{8}{|c|}{1999} \\
\hline 15 May & 0.065 & 0.071 & 17 & 0.048 & 0.022 & 4.9 & 0.34 \\
\hline 26 May & 0.070 & 0.10 & 23 & 0.032 & 0.045 & 0.4 & 0.64 \\
\hline \multicolumn{8}{|c|}{2000} \\
\hline 2 May & 0.058 & 0.049 & 15 & 0.042 & 0.022 & 1.5 & 0.38 \\
\hline
\end{tabular}

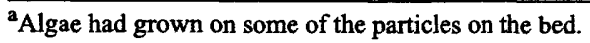

${ }^{b}$ The sample had a high proportion of organic matter.

${ }^{\mathrm{c}}$ The flash flood on 9 July 1998 moved a 1-m boulder located on section 1200. 
Table 6.8. Threshold data for bed-load movement in Buffalo Creek

[Dimensionless shear stress, $\tau^{*}=\tau /\left(g \cdot\left(\rho_{s}-\rho\right) \cdot D_{b}\right)$; where $\tau$ is the total bed shear stress, $g$ is $9.8 \mathrm{~m} / \mathrm{s}^{2}, \rho_{s}$ is assumed to be $2,650 \mathrm{~kg} / \mathrm{m}^{3}, \rho$ is density of water, and $D_{b}$ is the median diameter of the largest class size moved; $\mathrm{m}$, meter; $\mathrm{m}^{3} / \mathrm{s} / \mathrm{m}$, cubic meter per second per meter; $\mathrm{N} / \mathrm{m}^{2}$, newton per square meter]

\begin{tabular}{|c|c|c|c|c|c|c|c|}
\hline Date & $\begin{array}{c}\text { Mean depth } \\
h \\
\text { (m) }\end{array}$ & $\begin{array}{c}\text { Unit discharge } \\
\left(\mathrm{m}^{3} / \mathrm{s} / \mathrm{m}\right)\end{array}$ & $\begin{array}{c}\text { Total bed shear } \\
\text { stress } \\
\tau \\
\left(\mathbf{N} / \mathbf{m}^{\mathbf{2}}\right)\end{array}$ & $\begin{array}{c}\text { Dimensionless } \\
\text { shear stress } \\
\tau^{*}\end{array}$ & $\begin{array}{l}D_{b} \\
\text { (m) }\end{array}$ & $\begin{array}{c}\text { Percent of } \\
\text { total }\end{array}$ & $\frac{D_{b}}{h}$ \\
\hline \multicolumn{8}{|c|}{1997} \\
\hline 20 March & 0.063 & 0.044 & 5.7 & 0.033 & 0.011 & 3.8 & 0.17 \\
\hline I July & 0.074 & 0.061 & 6.7 & 0.019 & 0.022 & 0.6 & 0.30 \\
\hline 14 July $^{\mathbf{a}}$ & 0.053 & 0.029 & 5.2 & 0.015 & 0.022 & 0.4 & 0.42 \\
\hline 14 July $^{\mathrm{a}}$ & 0.064 & 0.045 & 6.9 & 0.019 & 0.022 & 0.9 & 0.34 \\
\hline 19 Aug. & 0.070 & 0.060 & 7.5 & 0.010 & 0.045 & 0.5 & 0.64 \\
\hline 1 Sept. $^{a}$ & 0.096 & 0.094 & 12 & 0.034 & 0.022 & 0.9 & 0.23 \\
\hline 3 Nov. $^{b}$ & 0.094 & 0.098 & 14 & 0.039 & 0.022 & 1.9 & 0.23 \\
\hline 3 Nov. $^{b}$ & 0.085 & 0.078 & 11 & 0.031 & 0.022 & 1.2 & 0.26 \\
\hline 7 Nov. & 0.11 & 0.12 & 16 & 0.045 & 0.022 & 0.5 & 0.20 \\
\hline \multicolumn{8}{|c|}{1998} \\
\hline $9 \mathrm{May}^{\mathrm{c}}$ & 0.11 & 0.11 & 8.6 & 0.024 & 0.022 & 1.4 & 0.20 \\
\hline $9 \mathrm{May}^{\mathrm{c}}$ & 0.16 & 0.26 & 24 & 0.033 & 0.045 & 0.3 & 0.28 \\
\hline 22 July & 0.14 & 0.090 & 21 & 0.059 & 0.022 & 0.9 & 0.16 \\
\hline 7 Aug. & 0.096 & 0.12 & 13 & 0.037 & 0.022 & 0.4 & 0.23 \\
\hline \multicolumn{8}{|c|}{1999} \\
\hline 26 May & 0.24 & 0.38 & 35 & 0.098 & 0.022 & 1.4 & 0.092 \\
\hline \multicolumn{8}{|c|}{2000} \\
\hline 4 June & 0.15 & 0.072 & 3.8 & 0.021 & 0.011 & 4.9 & 0.073 \\
\hline
\end{tabular}

${ }^{\mathrm{a}}$ First measurement was made about $79 \mathrm{~m}$ upstream from the mouth and the second measurement was made $480 \mathrm{~m}$ upstream from the mouth. ${ }^{b}$ Root obstructions were removed from channel and may have loosened the bed so the measurements were taken after waiting 30 minutes.

${ }^{\mathrm{c}}$ Two replicates in the morning were combined with 4 replicates collected in the afternoon. 


\section{Table 6.9. Summary of total sediment transport estimates in Spring Creek for selected flash floods based on the change in volume of sediment in the study reach}

[A bulk density of $1,700 \mathrm{~kg} / \mathrm{m}^{3}$ was used to convert from volume to mass; $\Delta V$, change in volume of sediment in the study reach; $\Delta t$, estimated duration of flash flood $D_{s}$, maximum particle size in suspension; $D_{b}$, median diamater of largest size-class transported as bed load; $\mathrm{q}_{\mathrm{s}}$ and $\mathrm{q}_{\mathrm{b}}$ are the estimated suspended and bed load discharge; $\mathrm{m}$, meter; $\mathrm{s}$, second; $\mathrm{m}^{3}$, cubic meter; $\mathrm{m}^{3} / \mathrm{s}$, cubic meter per second; $\mathrm{m}^{3} / \mathrm{s} / \mathrm{m}$, cubic meter per second per meter; $\mathrm{kg} / \mathrm{s}$, kilogram per second; $\mathrm{kg} / \mathrm{s} / \mathrm{m}$, kilogram per second per meter; $\mathrm{mm}$, millimeter]

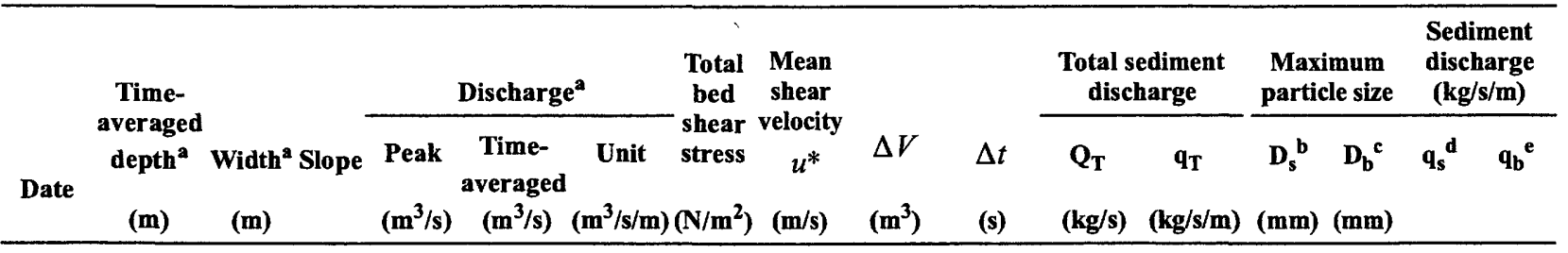

$\begin{array}{llrllllllllllllll}\text { 29 July } & 0.23 & 7.3 & 0.04 & 5.0 & 2.5 & 0.34 & 90 & 0.30 & 630^{\mathrm{f}} & 6,800 & 160 & 22 & 2.2 & 750 & 4.2 & 18 \\ \text { 31 July } & 0.23 & 7.3 & 0.04 & 3.6 & 2.3 & 0.32 & 90 & 0.30 & 630^{\mathrm{f}} & 6,000 & 180 & 25 & 2.2 & 750 & 4.8 & 20 \\ \text { 26 Aug. } & 0.24 & 7.4 \cdot & 0.04 & 6.6 & 2.7 & 0.36 & 94 & 0.31 & 1,090^{\mathrm{g}} & 6,300 & 290 & 39 & 2.3 & 790 & 7.5 & 31 \\ \text { 31 Aug. } & 1.5 & 11.1 & 0.04 & 140 & 61 & 5.5 & 590 & 0.77 & 16,620^{\mathrm{g}} & 7,200 & 3,900 & 350 & 11.0>1,000 & 230 & 120\end{array}$

1998

$\begin{array}{rlrrrrrrrrrrrrrr}\text { 9 July } & 0.69 & 9.0 & 0.04 & 48 & 9.7 & 1.0 & 270 & 0.52 & 520 & 6,000 & 150 & 15 & 5.8>1,000 & 7.5 & 7.5 \\ \text { 31 July } & 1.1 & 10.4 & 0.04 & 82 & 37 & 3.7 & 430 & 0.66 & 1,300 & 1,800 & 1,200 & 120 & 7.9>1,000 & 71 & 49\end{array}$

1999

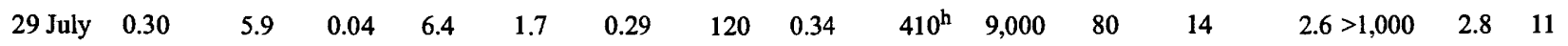

\footnotetext{
${ }^{a}$ Used Nash's (1958) linear reservoir model with $n=3$, and $\mathrm{K}$ ranging from 3.5-10.5 minutes, and the peak discharge to estimate the hydrograph by conserving the volume, which was measured at the gage site or downstream at the South Platte gage site if the Spring Creek gage malfunctioned. Time-averaged discharge was the volume of water divided by the duration of the flash flood. Time-averaged depth was determined from the discharge and the critical flow model applied to the geometry of the gage site (see table 3.5 ).
}

${ }^{\mathrm{b}} D_{s}$ was determined by iterating until Dietrich's (1982) fourth-order polynomial equation, which predicts settling velocity, equalled $u^{*}$.

'Solved the empirical equation for initiation of motion $\tau^{*}=0.021 \cdot\left(\frac{D_{b}}{h}\right)^{-0.88}$ for $D_{b}$, where $h$ is the time-averaged depth and $\tau^{*}$ is given by equation 6.5 .

${ }^{\mathrm{d}}$ Suspended load was proportional to the percent finer than $D_{s}$ based on Appendix 12.

${ }^{\mathrm{e}} \mathrm{Bed}$ load was proportional to (the percent finer than $D_{b}$ minus the percent finer than $D_{s}$ ) based on Appendix 12.

${ }^{\mathrm{f}}$ The two flash floods had the same magnitude so the total change in volume $\left(1,260 \mathrm{~m}^{3}\right)$ between $25 \mathrm{July}$ and 6 August 1997 was proportioned equally.

${ }^{\mathrm{g}}$ The total change in volume between channel surveys on 6 August and 31 August $1997\left(17,720 \mathrm{~m}^{3}\right.$, Table 5.2) was distributed to each flash flood by assuming the volume was proportional to the unit discharge.

${ }^{\mathrm{h}}$ The flash flood eroded $410 \mathrm{~m}^{3}$ between the mouth and $679 \mathrm{~m}$ upstream from the mouth; it deposited $330 \mathrm{~m}^{3}$ between $679 \mathrm{~m}$ and $1,470 \mathrm{~m}$. 


\section{Table 6.10. Bed-load transport efficiencies for selected streams and rivers}

[Efficiency, $100 \mathrm{x}$ bed-load transport rate/water discharge; bed characteristics are the averages where data were available; $D_{50}$, median diameter of bed material; $\mathrm{m}^{3} / \mathrm{s}$, cubic meter per second; $\mathrm{mm}$, millimeter; $\%$, percent]

\begin{tabular}{|c|c|c|c|c|c|}
\hline \multirow{2}{*}{ Location } & \multirow{2}{*}{$\begin{array}{c}\begin{array}{c}\text { Range } \\
\text { of } \\
\text { discharge }\end{array} \\
\left(\mathrm{m}^{3} / \mathrm{s}\right)\end{array}$} & \multicolumn{2}{|c|}{ Typical } & Efficiency & \multirow{2}{*}{ Reference } \\
\hline & & Slope & $\begin{array}{l}D_{50} \\
(\mathrm{~mm})\end{array}$ & $\begin{array}{c}\text { Maximum } \\
(\%)\end{array}$ & \\
\hline $\begin{array}{l}\text { Rio Solimoès and Rio Amazon } \\
\text { between Iquitos, Peru and Obidos, } \\
\text { Brazil }\end{array}$ & $\begin{array}{r}43,600 \\
235,000\end{array}$ & 0.00005 & 0.2 & $\begin{array}{l}0.00081 \\
0.0035\end{array}$ & Posada, 1995. \\
\hline Tanana River at Fairbanks, Alaska & $\begin{array}{r}345 \\
2,020\end{array}$ & 0.0005 & 5 & $\begin{array}{l}0.00070 \\
0.0068\end{array}$ & $\begin{array}{l}\text { Burrows and others, } 1981 . \\
\text { Williams and Rosgen, } 1989 .\end{array}$ \\
\hline $\begin{array}{l}\text { Toutle River at Tower Road near } \\
\text { Silver Lake, Washington }\end{array}$ & $\begin{array}{l}12.0 \\
592\end{array}$ & 0.003 & no data & $\begin{array}{l}0.0077 \\
0.17\end{array}$ & Williams and Rosgen, 1989. \\
\hline $\begin{array}{l}\text { East Fork River near Pinedale, } \\
\text { Wyoming }\end{array}$ & $\begin{array}{l}2.67 \\
22.4\end{array}$ & 0.0007 & 3 & $\begin{array}{l}0.0023 \\
0.033\end{array}$ & Williams and Rosgen, 1989. \\
\hline $\begin{array}{l}\text { Muddy Creek near Pinedale, } \\
\text { Wyoming }\end{array}$ & $\begin{array}{l}0.18 \\
1.57\end{array}$ & 0.0012 & no data & $\begin{array}{l}0.0014 \\
0.058\end{array}$ & Williams and Rosgen, 1989. \\
\hline Nahal Yael, southern Negev, Israel & $\begin{array}{l}0.032 \\
0.36\end{array}$ & 0.08 & 4 & $\begin{array}{l}0.018 \\
7.5\end{array}$ & $\begin{array}{l}\text { Lekach and others, } 1992 . \\
\text { Lekach and Schick, } 1983 .\end{array}$ \\
\hline Oak Creek, Oregon & $\begin{array}{l}0.15 \\
3.4\end{array}$ & 0.01 & 3 & $\begin{array}{l}0.000000075 \\
0.018\end{array}$ & Milhous, 1973. \\
\hline $\begin{array}{l}\text { Buffalo Creek at Buffalo Creek, } \\
\text { Colorado (pre-fire) }\end{array}$ & $\begin{array}{l}0.42 \\
1.56\end{array}$ & 0.02 & no data & $\begin{array}{l}0.0011 \\
0.087\end{array}$ & Williams and Rosgen, 1989. \\
\hline $\begin{array}{l}\text { Buffalo Creek at mouth near } \\
\text { Buffalo Creek, Colorado (postfire) }\end{array}$ & $\begin{array}{l}0.25 \\
5.2\end{array}$ & 0.02 & 2 & $\begin{array}{l}0.0019 \\
0.76\end{array}$ & This report. \\
\hline $\begin{array}{l}\text { Spring Creek at mouth near South } \\
\text { Platte, Colorado (post-fire) }\end{array}$ & $\begin{array}{l}0.0078 \\
0.21\end{array}$ & 0.04 & 5 & $\begin{array}{l}0.34 \\
2.3\end{array}$ & This report. \\
\hline
\end{tabular}


Table 6.11. Ratio of the percent sediment transported as bed load to the percent sediment available in the bed of Spring Creek

[Percent sediment available depends upon the size classes transported only as bed load (see table 6.4 which gives raw values) and the bed-material size distribution given in table 6.1 which was recalculated by including only the bed-load size classes; $D_{b}$, median diamater of largest size-class transported as bed load; $h$, water depth; $\mathrm{mm}$, millimeter; $\mathrm{N} / \mathrm{m}^{2}$, newton per square meter; $\mathrm{m}^{3} / \mathrm{s} / \mathrm{m}$, cubic meter per second per meter; $\mathrm{nm}$, not moving]

\begin{tabular}{|c|c|c|c|c|c|c|c|c|c|c|c|c|}
\hline \multirow{2}{*}{ Date } & \multicolumn{9}{|c|}{ Ratio $=\frac{\text { Sediment } \text { Transported }}{\text { Sediment Available }}$} & \multirow{2}{*}{$D_{b} / h$} & \multirow{2}{*}{$\begin{array}{c}\text { Total } \\
\text { shear } \\
\text { stress } \\
\left(\mathrm{N} / \mathbf{m}^{2}\right)\end{array}$} & \multirow{2}{*}{$\begin{array}{c}\text { Unit } \\
\text { discharge } \\
\left(\mathrm{m}^{3} / \mathrm{s} / \mathrm{m}\right)\end{array}$} \\
\hline & $\begin{array}{cc}0.125- & 0.250 \\
0.250 & 0.500 \\
\mathrm{~mm} & \mathrm{~mm}\end{array}$ & $\begin{array}{c}0.500- \\
1.00 \\
\mathrm{~mm}\end{array}$ & $\begin{array}{l}1-2 \\
\mathrm{~mm}\end{array}$ & $\begin{array}{l}2-4 \\
\mathrm{~mm}\end{array}$ & $\begin{array}{l}4-8 \\
\mathrm{~mm}\end{array}$ & $\begin{array}{l}8-16 \\
\mathrm{~mm}\end{array}$ & $\begin{array}{c}16-32 \\
\mathrm{~mm}\end{array}$ & $\begin{array}{c}32-64 \\
\mathrm{~mm}\end{array}$ & $\begin{array}{c}\text { 64-128 } \\
\mathrm{mm}\end{array}$ & & & \\
\hline \multicolumn{13}{|c|}{1997} \\
\hline 28 June & in suspension & 1.76 & 1.65 & 1.13 & 0.76 & 0.86 & 0.37 & $\mathrm{~nm}$ & $\mathrm{~nm}$ & 0.34 & 25 & 0.026 \\
\hline 2 July & in suspension & 0.88 & 1.18 & 1.02 & 0.88 & 1.25 & 0.70 & $\mathrm{~nm}$ & $\mathrm{~nm}$ & 0.65 & 13 & 0.013 \\
\hline 11 July $^{a}$ & in suspension & 1.63 & 1.94 & 1.43 & 0.71 & 0.21 & $\mathrm{~nm}$ & $\mathrm{~nm}$ & $\mathrm{~nm}$ & 0.52 & 5.4 & 0.0059 \\
\hline 3 August & in suspension & 1.36 & 1.08 & 1.07 & 1.00 & 1.38 & 0.80 & 0.03 & $\mathrm{~nm}$ & 0.67 & 20 & 0.036 \\
\hline 5 August & in suspension & 1.11 & 0.69 & 0.75 & 0.92 & 2.22 & 3.86 & 0.25 & 0.19 & 1.0 & 28 & 0.056 \\
\hline 15 Sept. & in suspension & 1.02 & 1.21 & 1.06 & 0.71 & 1.29 & 1.72 & $\mathrm{~nm}$ & $\mathrm{~nm}$ & 0.46 & 15 & 0.029 \\
\hline 9 Oct. & in suspension & 1.73 & 1.49 & 1.01 & 0.69 & 1.21 & 0.94 & $\mathrm{~nm}$ & $\mathrm{~nm}$ & 0.54 & 11 & 0.027 \\
\hline \multicolumn{13}{|c|}{1998} \\
\hline 21 May & in suspension & 1.29 & 0.85 & 0.79 & 0.97 & 1.69 & 1.42 & 0.38 & $\mathrm{~nm}$ & 0.90 & 15 & 0.059 \\
\hline 26 June & in suspension & 0.68 & 0.97 & 0.92 & 0.96 & 1.46 & 0.65 & $\mathrm{~nm}$ & $\mathrm{~nm}$ & 0.47 & 12 & 0.037 \\
\hline 5 August & in suspension & 1.08 & 0.96 & 0.83 & 0.88 & 1.48 & 1.40 & $\mathrm{~nm}$ & $\mathrm{~nm}$ & 0.46 & 16 & 0.052 \\
\hline \multicolumn{13}{|c|}{1999} \\
\hline 15 May & in suspension & 0.88 & 1.03 & 0.93 & 0.88 & 1.36 & 1.19 & $\mathrm{~nm}$ & $\mathrm{~nm}$ & 0.34 & 17 & 0.071 \\
\hline 26 May & in suspension & 0.95 & 0.87 & 0.89 & 0.92 & 1.81 & 1.91 & 0.05 & $\mathrm{~nm}$ & 0.64 & 23 & 0.10 \\
\hline \multicolumn{13}{|c|}{2000} \\
\hline 2 May & in suspension & 2.34 & 1.46 & 0.86 & 0.84 & 1.06 & 0.37 & $\mathrm{~nm}$ & $\mathrm{~nm}$ & 0.38 & 15 & 0.049 \\
\hline
\end{tabular}

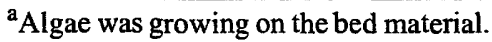


Table 6.12. Ratio of the percent sediment transported as bed load to the percent sediment available in the bed of Buffalo Creek

[Percent sediment available depends upon the size classes transported only as bed load (see table 6.4 which gives raw values) and the bed-material size distribution given in table 6.1 which was recalculated by including only the bed-load size classes; $D_{b}$, median diamater of largest size-class transported as bed load; $h$, water depth; $\mathrm{mm}$, millimeter; $\mathrm{N} / \mathrm{m}^{2}$, newton per square meter; $\mathrm{m}^{3} / \mathrm{s} / \mathrm{m}$, cubic meter per second per meter; nm, not moving]

\begin{tabular}{|c|c|c|c|c|c|c|c|c|c|c|c|c|c|}
\hline \multirow{2}{*}{ Date } & \multicolumn{10}{|c|}{ Ratio $=\frac{\text { Sediment Transported }}{\text { Sediment Available }}$} & \multirow{2}{*}{$\mathbf{D}_{\mathbf{b}} / \mathbf{h}$} & \multirow{2}{*}{$\begin{array}{c}\text { Total } \\
\text { shear } \\
\text { stress } \\
\left(\mathrm{N} / \mathbf{m}^{2}\right)\end{array}$} & \multirow{2}{*}{$\begin{array}{c}\text { Unit } \\
\text { discharge } \\
\left(\mathrm{m}^{3} / \mathrm{s} / \mathrm{m}\right)\end{array}$} \\
\hline & $\begin{array}{c}0.125- \\
0.250 \\
\mathrm{~mm}\end{array}$ & $\begin{array}{c}0.250- \\
0.500 \\
\mathrm{~mm}\end{array}$ & $\begin{array}{c}0.500- \\
1.00 \\
\mathrm{~mm}\end{array}$ & $\begin{array}{l}1-2 \\
\mathrm{~mm}\end{array}$ & $\begin{array}{l}2-4 \\
\mathrm{~mm}\end{array}$ & $\begin{array}{l}4-8 \\
\mathrm{~mm}\end{array}$ & $\begin{array}{l}8-16 \\
\mathrm{~mm}\end{array}$ & $\begin{array}{c}16-32 \\
\mathrm{~mm}\end{array}$ & $\begin{array}{c}\text { 32-64 } \\
\text { mm }\end{array}$ & $\begin{array}{c}\text { 64-128 } \\
\mathrm{mm}\end{array}$ & & & \\
\hline \multicolumn{14}{|c|}{1997} \\
\hline 20 March & in sus! & ension & 1.70 & 1.33 & 0.91 & 0.67 & 0.44 & $\mathrm{~nm}$ & $\mathrm{~nm}$ & $\mathrm{~nm}$ & 0.17 & 5.7 & 0.044 \\
\hline 1 July & in sus & ension & 1.08 & 1.05 & 0.97 & 1.00 & 1.01 & 0.38 & $\mathrm{~nm}$ & $\mathrm{~nm}$ & 0.30 & 6.7 & 0.061 \\
\hline 14 July & in sus] & ension & 1.22 & 1.16 & 1.02 & 0.90 & 0.75 & 0.24 & $\mathrm{~nm}$ & $\mathrm{~nm}$ & 0.42 & 5.2 & 0.029 \\
\hline 14 July & in sus] & ension & 0.93 & 1.01 & 1.07 & 1.05 & 0.86 & 0.48 & $\mathrm{~nm}$ & $\mathrm{~nm}$ & 0.34 & 6.9 & 0.045 \\
\hline 19 August & in sus! & ension & 0.85 & 0.98 & 1.06 & 1.02 & 1.11 & 1.18 & 0.38 & $\mathrm{~nm}$ & 0.64 & 7.5 & 0.060 \\
\hline 1 Sept. & in sus! & ension & 1.18 & 1.05 & 0.99 & 0.96 & 0.89 & 0.54 & $\mathrm{~nm}$ & $\mathrm{~nm}$ & 0.23 & 12 & 0.094 \\
\hline 3 Nov. $^{a}$ & in sus! & ension & 0.97 & 0.96 & 1.02 & 0.98 & 1.17 & 0.81 & $\mathrm{~nm}$ & $\mathrm{~nm}$ & 0.24 & 12 & 0.080 \\
\hline \multicolumn{14}{|c|}{1998} \\
\hline 9 May & in sus! & ension & 1.25 & 1.03 & 0.89 & 0.98 & 1.00 & 0.85 & $\mathrm{~nm}$ & $\mathrm{~nm}$ & 0.20 & 8.6 & 0.11 \\
\hline 9 May & in sust & ension & 1.07 & 1.08 & 0.95 & 1.02 & 1.01 & 0.79 & 0.21 & $\mathrm{~nm}$ & 0.28 & 24 & 0.26 \\
\hline 22 July & in sus! & ension & 1.19 & 0.89 & 0.98 & 1.11 & 0.84 & 0.54 & $\mathrm{~nm}$ & $\mathrm{~nm}$ & 0.16 & 21 & 0.090 \\
\hline 7 August & in sus & ension & 1.35 & 1.29 & 0.94 & 0.80 & 0.76 & 0.25 & $\mathrm{~nm}$ & $\mathrm{~nm}$ & 0.23 & 13 & 0.096 \\
\hline \multicolumn{14}{|c|}{1999} \\
\hline 26 May & in susf & ension & 1.07 & 1.02 & 1.04 & 0.95 & 0.97 & 0.76 & $\mathrm{~nm}$ & $\mathrm{~nm}$ & 0.092 & 35 & 0.24 \\
\hline \multicolumn{14}{|c|}{2000} \\
\hline 4 June & in sus! & ension & 1.10 & 1.10 & 1.13 & 0.91 & 0.54 & $\mathrm{~nm}$ & $\mathrm{~nm}$ & $\mathrm{~nm}$ & 0.073 & 3.8 & 0.072 \\
\hline
\end{tabular}

\footnotetext{
${ }^{\mathrm{a}}$ The morning and afternoon measurements were averaged.
} 


\section{Section 7-RESERVOIR}

\section{Methods}

Strontia Springs Reservoir is approximately $2,700 \mathrm{~m}$ long and $150 \mathrm{~m}$ wide (fig. 7.1) and traps coarse sediments (sand and gravel) in the upstream end and fine sediments (silt and clays) in the downstream end. Coarse sediment deposition in the reservoir was monitored after the Buffalo Creek Fire by measuring a single bathymetric profile along the center line using an acoustical fathometer (Lowrance Model X16). This was sufficient to represent the average bottom elevation and also avoided problems of sound scattering in the vicinity of steep canyon walls. Distances were measured downstream from the Denver Water Department station 15 (fig. 7.1), near the upper end of the reservoir. The Denver Water Department monumented stations with brass bench marks on both sides of the reservoir and above the normal pool elevation $(1,829 \mathrm{~m}$ or 6,002 feet). Distances between stations were divided into ten equal intervals and the longitudinal profiles were digitized at these intervals, which were not necessarily equal along the entire profile (Appendix 13). The distances and elevations (corrected for actual water-level elevation) for each survey are in files on the accompanying $\mathrm{CD}$ and the format of these files is listed in Appendix 14.

To calculate the change in volume of coarse sediment, it was assumed that the sediment formed a horizontal surface across the reservoir. The change in volume of coarse sediment (sand and gravel) that accumulated in the upper end of Strontia Springs Reservoir between bathymetric surveys was calculated from the difference in elevation between the longitudinal bathymetric profiles and using the widths of the canyon, measured from a topographic map (scale 1 inch $=200$ feet) provided by the Denver Water Department. Average sediment transport rates into the reservoir were estimated by dividing the change in volume by the time between bathymetric surveys. Conversion between sediment volume and sediment mass was calculated using an average bulk density of $1,700 \mathrm{~kg} / \mathrm{m}^{3}$ based on bed-load material collected in Buffalo and Spring Creeks. These data and calculated results are shown in table 7.1.

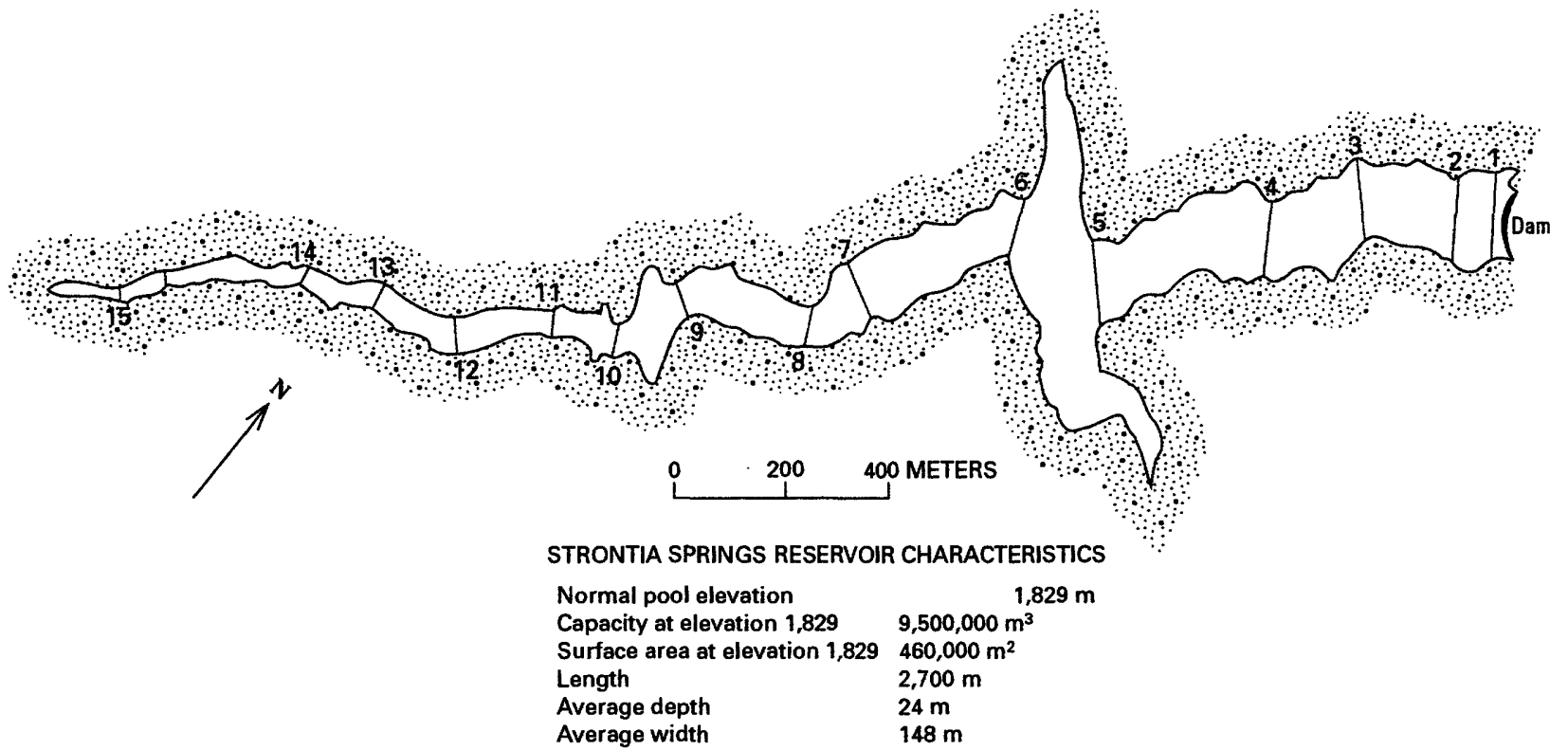

Figure 7.1 Strontia Springs Reservoir on the South Platte River near Denver. The numbers along the edge of the reservoir indicate sections that have benchmarks maintained by the Denver Water Department. 
Samples of the fine-sediment fraction (silt and clays) were obtained in February and March 1997 by using a gravity corer through the ice at stations 4 and 7 (fig. 7.1). A modified Wildco corer (approximately $5-\mathrm{cm}$ diameter) with $6.4 \mathrm{~kg}$ of lead clamped onto the stainless-steel barrel was allowed to free fall from about $3 \mathrm{~m}$ above the bottom and then was driven into the sediment using a $18-\mathrm{kg}$ weight. This technique produced a $1.39-\mathrm{m}-$ long core (core $4 \mathrm{~B}$ ) at station 4 and a $0.74-\mathrm{m}$-long core (core $7 \mathrm{~A}$ ) at station 7 .

Subsamples were analyzed from core $4 \mathrm{~B}$ at $0.02-0.04 \mathrm{~m}, 0.50-0.52 \mathrm{~m}, 0.90-0.92 \mathrm{~m}$, and 1.06-1.08 $\mathrm{m}$ below the sediment surface for particle size, loss on ignition, and metals analysis. The sediment was analyzed by sequential extraction digestion (Hayes, 1993) which gave results for 47 elements and silicon dioxide. Bulk density and particle size were also determined for subsamples collected from $0-0.20 \mathrm{~m}, 0.20-0.50 \mathrm{~m}, 0.52-0.80 \mathrm{~m}, 0.80-0.99 \mathrm{~m}$, and $0.99-1.39 \mathrm{~m}$. A sample was also analyzed from core 7A for particle size at $0.49-0.74 \mathrm{~m}$ below the sediment surface.

\section{$\underline{\text { Results }}$}

\section{Sediment Deposition and Transport into the Reservoir}

Strontia Springs Reservoir trapped most of the coarse- and fine-grained sediment from the burned watersheds. The reservoir is relatively small, with an 85 percent trapping efficiency (Borland, 1978) that retains the coarsest fraction (sands and gravels) but passes some of the fine fraction, depending upon the size of the flood and how much water is being released at the dam. The initial floods in 1996 were so large that they transported some of the bed-load and suspended-load sediment from the burned watersheds into the reservoir in a few hours or days (table 7.1). Part of the suspended load (silt and clay) was trapped in the reservoir near the dam, but some passed through the reservoir during the 1996 flash flood and was trapped behind the Marston Diversion and Chatfield Dams farther downstream. The bed load, however, settled out and created a delta with an approximately 10-m high slip face (fig. 7.2A, Sept. 1996) in the upper end of Strontia Springs Reservoir. Measurements of the delta indicated that $52,000 \mathrm{~m}^{3}$ of fire-related, coarsegrained sediment was deposited on top of existing sediment (fig. 7.2, 7.3 and table 7.1). On the basis of a few sediment cores collected from the lower end of the reservoir during the winter of 1996-97, we estimated $0.5 \mathrm{~m}$ of fine grained sediment (about $100,000 \mathrm{~m}^{3}$ ) was deposited in the reservoir. Field measurements indicated an additional $2,500 \mathrm{~m}^{3}$ of mostly fine grained sediment (12 percent clay, 66 percent silt, 21 percent sand, and 1 percent gravel) was deposited downstream from the Marston Diversion Dam. Thus, the total sediment deposition in 1996 was about 154,000 $\mathrm{m}^{3}$.

Reservoir operations in September-October 1996 lowered the water level about $20 \mathrm{~m}$. As a result, the water cut a channel down through the upstream delta exposing a black layer of firerelated sediment (black band in fig. 7.2A, fig. 7.3), as well as sediment deposited before the wildfire. This initial channel later expanded laterally, eventually eroded most of the original sediment in the delta, transported it farther downstream into the reservoir (table 7.1, September 13 to October 2, 1996), and deposited it between Stations 12 and 9 (fig. 7.2A, June 1997). A new delta formed about $300 \mathrm{~m}$ downstream from station 15 by June 1997 . This face advanced about $200 \mathrm{~m}$ down the reservoir between June and September 1997, probably as a result of the severe flash floods during the summer of 1997. It advanced farther into the reservoir (about $120 \mathrm{~m}$ ) during the spring of 1998 (fig. 7.2B, May 1998) when reservoir operations again lowered the water level of 

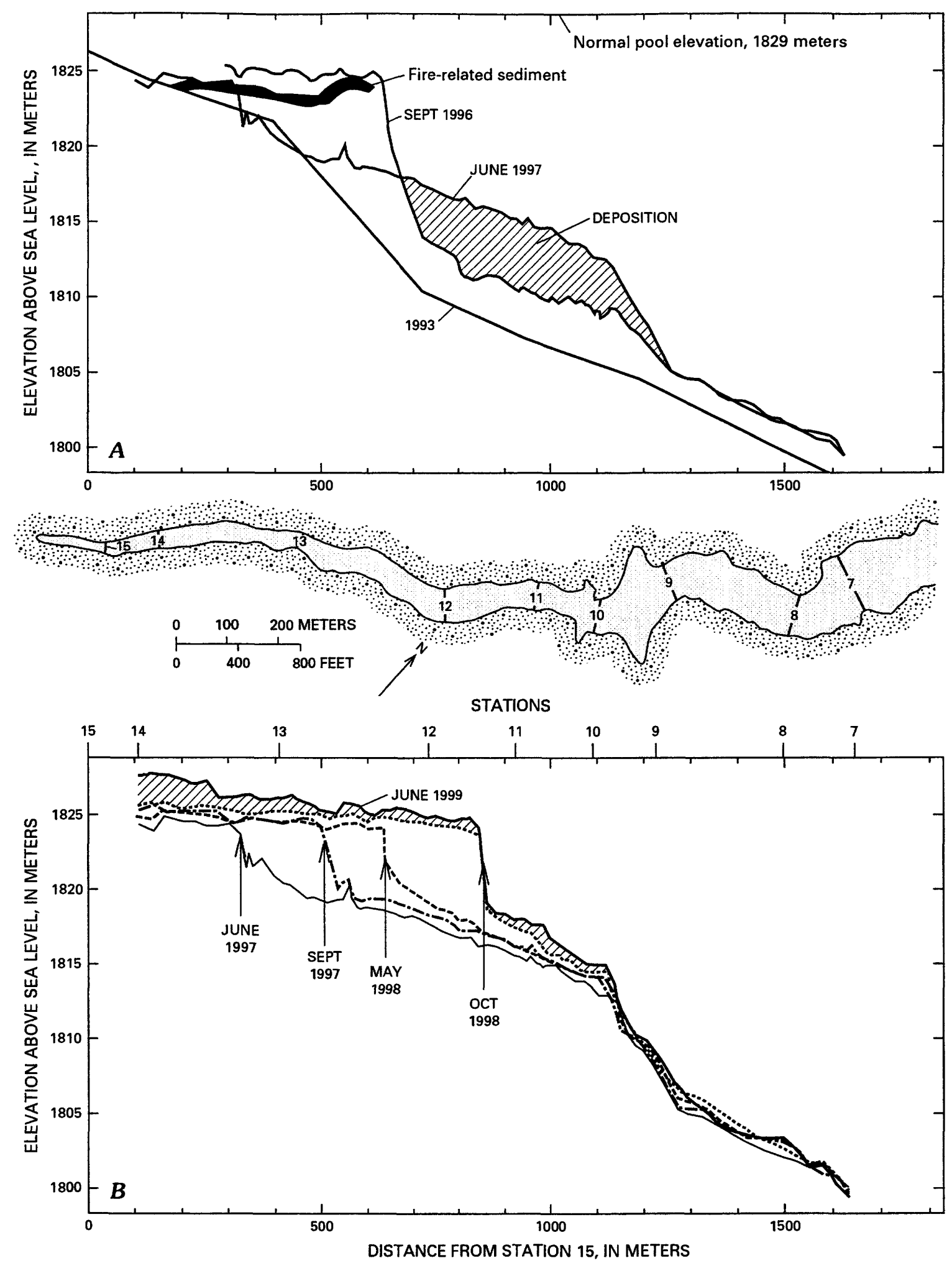

Figure 7.2 A. Longitudinal profiles of the upper part of Strontia Springs Reservoir. The original bottom is shown by the 1993 profile. The black layer in the Sept. 1996 profile represents the initial deposit of fire-related sediments that was later covered by fire-related coarse sand and gravel. The area of subsequent deposition (shown by cross hatching) was caused by erosion of the delta shown in Sept. 1996 when the water level in the reservoir was lowered. B. Successive longitudinal profiles are shown and the June 1997 profile is repeated from Figure 7.2A 


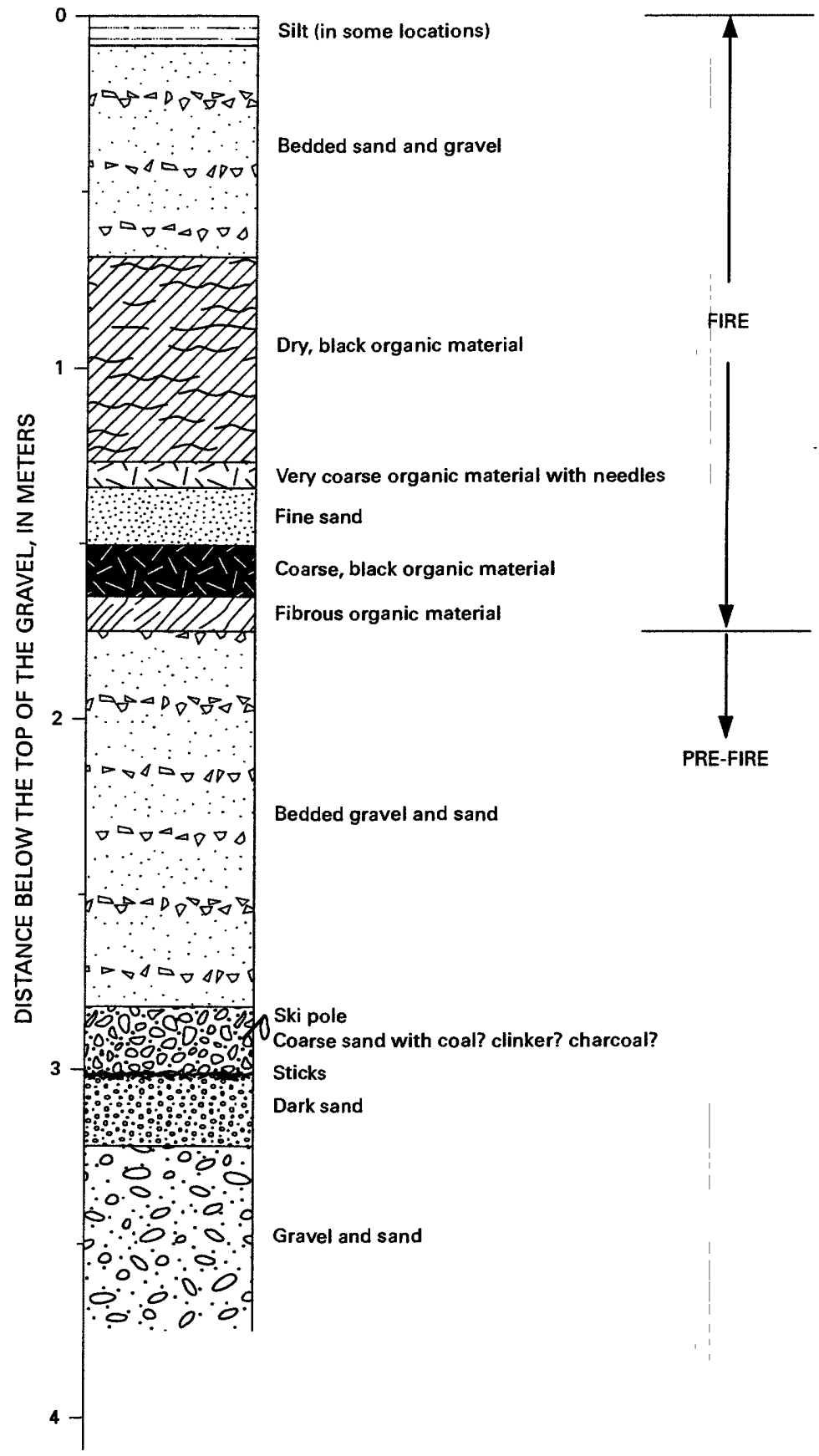

Figure 7.3 Stratigraphy of flood sediments at section 12-13 in Strontia Springs Reservoir.

the reservoir and the sediment transport rates increased (table 7.1, 22 May to 15 June 1998).

Flash floods later in July 1998 probably moved this face downstream an additional $210 \mathrm{~m}$ by October 1998 to a new location between Stations 11 and 12, where it remained through 4 June 1999. Additional sediment has been added to the delta since October 1998, not by advancing the face downstream, but by increasing the height of the delta in the upper end of the reservoir. This is perhaps in response to maintaining a higher level of the reservoir (above 1,829 $\mathrm{m}$ ) during the 
spring of 1999.

Sediment transport rates into the reservoir after 1996 reflect the complex response of reservoir operations and the transport and storage of sediment upstream. The pre-fire, bed-load transport rate of the South Platte River $(0.86 \mathrm{~kg} / \mathrm{s})$ was measured by Borland (1978) before the Strontia Springs Dam was built. Bed-load transport rates into the reservoir after the wildfire ranged from $0.89 \mathrm{~kg} / \mathrm{s}$ to $310 \mathrm{~kg} / \mathrm{s}$ (table 7.1). This range of transport rates probably depended upon (1) sediment storage in the channel reach upstream from the reservoir, (2) operation of Strontia Springs Reservoir, and 3) operation of other reservoirs upstream of the storage reach. For example, the transport rate after the flash flood on 31 August 1997 seems relatively low $(2.0 \mathrm{~kg} /$ s). Sediment from this flood was probably stored in the channel reach upstream from Strontia Springs Reservoir because discharge from the other upstream reservoirs was decreased near the end of the summer. The sediment was then transported $(18 \mathrm{~kg} / \mathrm{s})$ during the following spring when Strontia Springs Reservoir was lowered and water was released from other upstream reservoirs.

\section{Sediment Cores}

The interface between wildfire-related sediments and pre-fire sediments was distinct in only one core (4B). This interface was $0.99 \mathrm{~m}$ below the sediment surface, and the material above this interface fined upward from 65 percent silt and clay to 99.5 percent silt and clay (table 7.2 and fig. 7.4). Silty material just above the interface had a bulk density of $1,520 \mathrm{~kg} / \mathrm{m}^{3}$ with an organic content of 11 percent while the fibrous organic material below the interface had a bulk density of $1,200 \mathrm{~kg} / \mathrm{m}^{3}$ and an organic content of 41 percent. Measured concentrations of six metals (table 7.3) increased above the interface between pre-fire and fire-related sediment (fig. 7.5). This is associated with a decrease in particle size (table 7.2 and fig. 7.4), which is known to affect metal concentrations (Horowitz, 1991). 


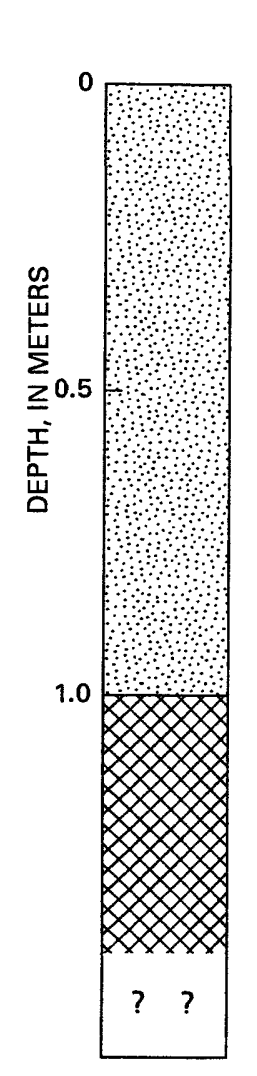

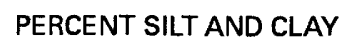

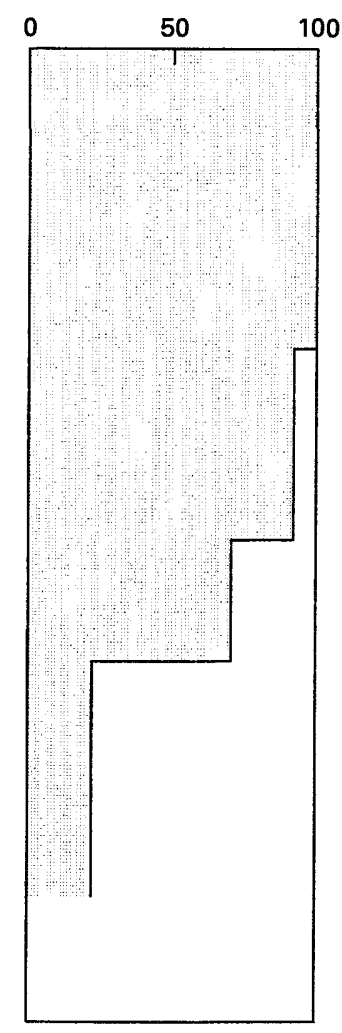

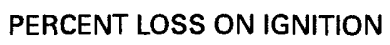

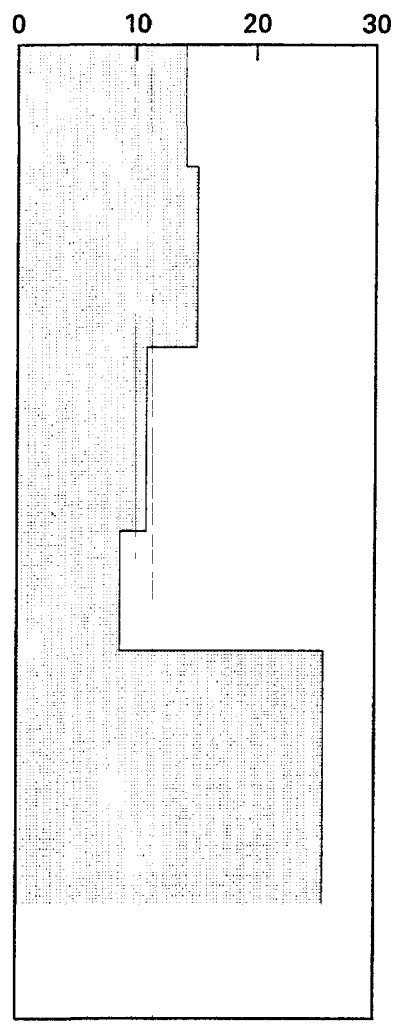

Figure 7.4 Changes in percent silt and clay and material lost on ignition (LOI) in a sediment core. Sediment core 4B was collected near section 4 in the middle of Strontia Springs Reservoir (see fig. 7.1). The stippling represents fire-related sediment above the interface at $99 \mathrm{~cm}$. The cross-hatching represents pre-fire sediment collected after the reservoir was filled with water. 

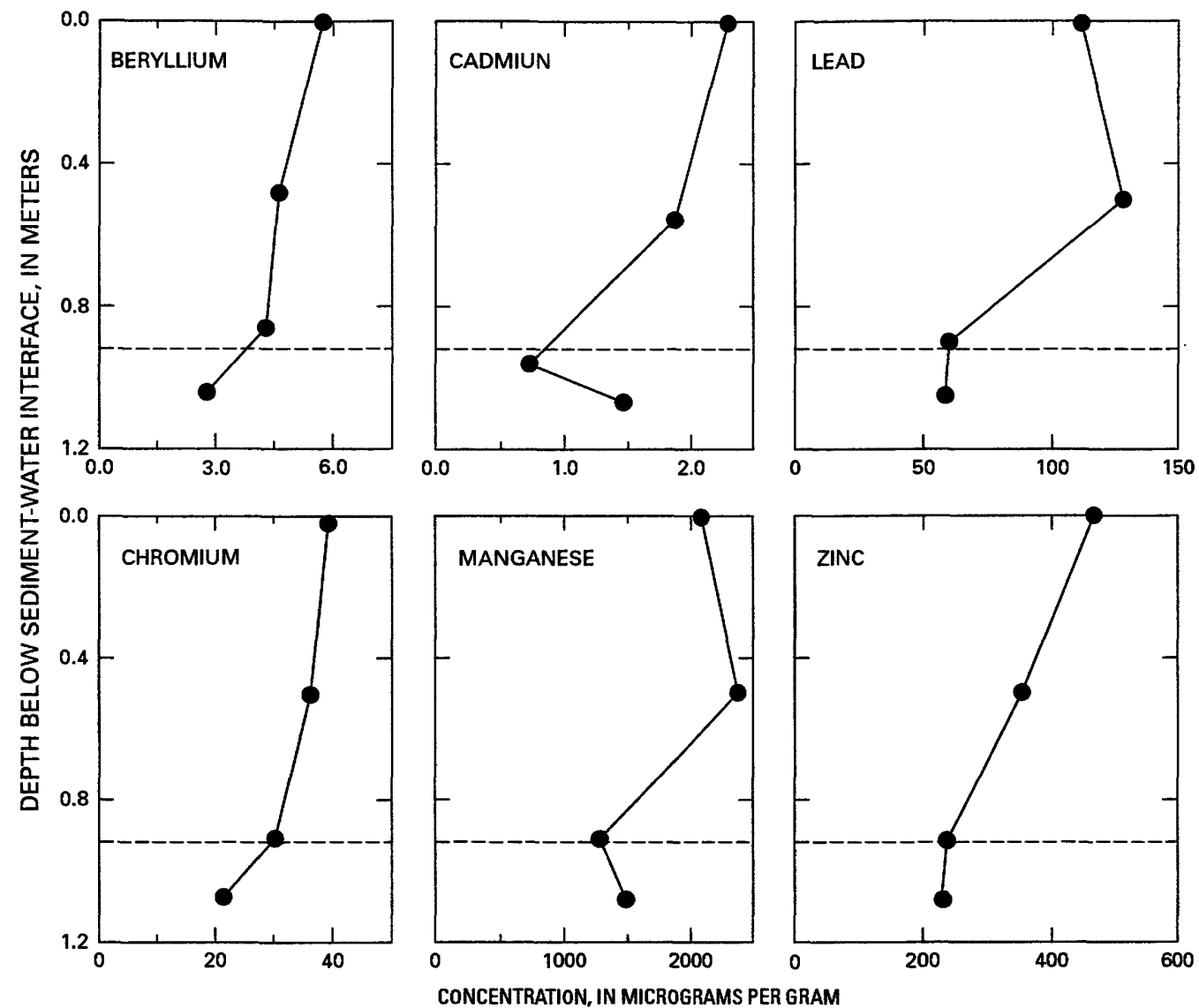

Figure 7.5 Change in metal concentrations in a sediment core. Sediment core 4B was collected near section 4 in the middle of Strontia Springs Reservoir (see fig. 7.1). The dashed line represents the interface between pre-fire sediments below and fire-related sediments above. 
Table 7.1. Measurements of coarse (sand and gravel) sediment deposition and transport into Strontia Springs Reservoir based on changes in sediment volume in the reservoir

[Used a bulk density of 1,700 kilograms per cubic meter; $\mathrm{m}^{3}$, cubic meter; $\mathrm{m}^{3} / \mathrm{d}$, cubic meter per day; $\mathrm{kg} / \mathrm{s}$, kilogram per second; $\mathrm{kg} / \mathrm{s} / \mathrm{m}$, kilogram per second per meter]

\begin{tabular}{|c|c|c|c|c|c|c|}
\hline \multirow[b]{2}{*}{ Deposition period } & \multirow[b]{2}{*}{ Days } & \multirow{2}{*}{$\begin{array}{l}\text { Sediment } \\
\text { volume } \\
\left(\mathrm{m}^{3}\right)\end{array}$} & \multicolumn{3}{|c|}{ Sediment transport rate } & \multirow[b]{2}{*}{ Comments } \\
\hline & & & $\begin{array}{l}\text { Volume } \\
\left(\mathrm{m}^{3} / \mathrm{d}\right)\end{array}$ & $\begin{array}{l}\text { Mass } \\
(\mathrm{kg} / \mathrm{s})\end{array}$ & $\begin{array}{l}\text { per unit } \\
\text { width } \\
(\mathrm{kg} / \mathrm{m} / \mathrm{s})\end{array}$ & \\
\hline \multicolumn{7}{|c|}{1996} \\
\hline $\begin{array}{c}\text { May 18, } 1996 \text { - } \\
\text { September 13, } \\
1996\end{array}$ & 2 & 31,000 & 16,000 & 310 & 16 & $\begin{array}{l}\text { Initial input was esti- } \\
\text { mated to occur in } 2 \\
\text { days. }\end{array}$ \\
\hline $\begin{array}{c}\text { September 13, } \\
1996 \text { - October 2, } \\
1996\end{array}$ & 19 & 21,000 & 1,100 & 22 & 1.1 & $\begin{array}{l}\text { Reservoir level was } \\
\text { lowered during depo- } \\
\text { sition period. }\end{array}$ \\
\hline \multicolumn{7}{|c|}{1997} \\
\hline $\begin{array}{c}\text { October 2, } 1996 \text { - } \\
\text { June 27, } 1997\end{array}$ & 268 & 12,000 & 45 & 0.89 & 0.044 & Winter. \\
\hline $\begin{array}{l}\text { June 27, } 1997 \text { - } \\
\text { August 13, } 1997\end{array}$ & 47 & 21,000 & 450 & 8.9 & 0.44 & -- \\
\hline $\begin{array}{c}\text { August 13, } 1997 \text { - } \\
\text { September 12, } \\
1997\end{array}$ & 30 & 3,100 & 100 & 2.0 & 0.10 & $\begin{array}{l}\text { Large flash flood } \\
\text { occurred on August } \\
31 \text {. }\end{array}$ \\
\hline \multicolumn{7}{|c|}{1998} \\
\hline $\begin{array}{c}\text { September 12, } \\
1997 \text { - May } 22, \\
1998\end{array}$ & 252 & 41,000 & 160 & 3.1 & 0.16 & Winter. \\
\hline $\begin{array}{c}\text { May 22, } 1998 \text { - } \\
\text { July 15, } 1998\end{array}$ & 54 & 50,000 & 930 & 18 & 0.90 & $\begin{array}{l}\text { Water level was low- } \\
\text { ered during the } \\
\text { spring. }\end{array}$ \\
\hline $\begin{array}{l}\text { July 15, } 1998 \text { - } \\
\text { August 3, } 1998\end{array}$ & 19 & 30,000 & 1,600 & 31 & 1.6 & $\begin{array}{l}\text { Large flash flood } \\
\text { occurred on July } 31 \text {. }\end{array}$ \\
\hline $\begin{array}{l}\text { August 3, } 1998 \text { - } \\
\text { October 23, } 1998\end{array}$ & 81 & 15,000 & 190 & 3.7 & 0.18 & -- \\
\hline \multicolumn{7}{|c|}{1999} \\
\hline $\begin{array}{c}\text { October 23, } 1998 \text { - } \\
\text { June 4, } 1999\end{array}$ & 224 & 26,000 & 120 & 2.4 & 0.12 & Winter. \\
\hline
\end{tabular}


Table. 7.2. Summary of particle-size distribution of fire-related sediments collected from Strontia Springs Reservoir and upstream from the Marston Diversion Dam

[m;, meter; mm, millimeter; *, mostly organic material]

\begin{tabular}{|c|c|c|c|c|c|c|c|c|c|c|c|}
\hline \multirow[b]{2}{*}{$\begin{array}{c}\text { Depth from } \\
\text { top } \\
\text { (m) }\end{array}$} & \multicolumn{11}{|c|}{ Percent of total sample } \\
\hline & $\begin{array}{c}< \\
0.004 \\
\mathrm{~mm}\end{array}$ & $\begin{array}{c}0.004- \\
0.063 \\
\mathrm{~mm}\end{array}$ & $\begin{array}{c}0.063- \\
0.125 \\
\mathrm{~mm}\end{array}$ & $\begin{array}{c}0.125- \\
0.250 \\
\mathrm{~mm}\end{array}$ & $\begin{array}{c}0.250- \\
0.500 \\
\mathrm{~mm}\end{array}$ & $\begin{array}{c}0.500- \\
1.00 \\
\mathrm{~mm}\end{array}$ & $\begin{array}{l}1-2 \\
\mathrm{~mm}\end{array}$ & $\begin{array}{l}2-4 \\
\mathrm{~mm}\end{array}$ & $\begin{array}{l}\text { 4-8 } \\
\mathrm{mm}\end{array}$ & $\begin{array}{l}8-16 \\
\mathrm{~mm}\end{array}$ & $\begin{array}{c}16-32 \\
\mathrm{~mm}\end{array}$ \\
\hline
\end{tabular}

Vertical profile of deltaic sediments $\sim \mathbf{4 0}$ m upstream from Station 12-13 on left bank-1997

\begin{tabular}{|c|c|c|c|c|c|c|c|c|c|c|c|}
\hline surface & 3.6 & 39.3 & 31.0 & 14.3 & $* 4.7$ & $* 7.1$ & 0.0 & & & & \\
\hline $0.01-0.60$ & 0.0 & 0.0 & 0.4 & 3.7 & 14.5 & 15.7 & 12.3 & 14.7 & 19.3 & 15.5 & 3.7 \\
\hline $0.60-1.20$ & 1.6 & 25.0 & 42.0 & 23.4 & 5.1 & 2.8 & 0.0 & & & & \\
\hline $1.20-1.28$ & 3.6 & 28.7 & 26.2 & 16.2 & 7.3 & $* 18.0$ & 0.0 & & & & \\
\hline $1.28-1.45$ & 2.7 & 19.9 & 53.1 & 18.4 & *0.6 & *5.3 & 0.0 & & & & \\
\hline $1.45-1.60$ & 18.7 & 38.6 & 17.2 & 11.0 & 7.4 & 7.1 & 0.0 & & & & \\
\hline $1.60-1.70$ & 11.4 & 27.3 & 27.9 & 11.9 & 5.0 & $* 16.5$ & 0.0 & & & & \\
\hline $1.70-2.80$ & \multicolumn{2}{|c|}{$<0.1$} & 0.1 & 0.5 & 2.5 & 10.1 & 20.0 & 27.4 & 22.3 & 17.1 & 0.0 \\
\hline $2.80-3.00$ & \multicolumn{2}{|c|}{3.5} & 1.1 & 2.8 & 27.0 & 28.2 & 7.9 & 6.8 & 4.1 & 18.6 & 0.0 \\
\hline $3.00-3.20$ & 2.1 & 11.8 & 9.7 & *68.1 & *7.7 & $* 0.6$ & 0.0 & & & & \\
\hline
\end{tabular}

Sediment core collected near Station 4-1997

$\begin{array}{lrrrrrrr}0.00-0.20 & 38.4 & 61.1 & 0.4 & 0.1 & 0.0 & & \\ 0.20-0.50 & 39.8 & 58.6 & 1.4 & 0.1 & 0.0 & & \\ 0.50-0.80 & 12.2 & 79.9 & 6.7 & 1.0 & 0.2 & * 0.1 & 0.0 \\ 0.80-0.99 & 9.6 & 55.4 & 24.0 & * 8.7 & * 1.6 & * 0.7 & 0.0 \\ 0.99-1.395 & 2.8 & 17.8 & 38.0 & * 18.4 & * 6.1 & * 16.9 & 0.0\end{array}$

Sediment core collected near Station 7--1997

$\begin{array}{llllll}0.49-0.74 & 13.8 & 76.3 & 9.4 & 0.4 & * 0.1\end{array}$

Sediment collected $\sim 300$ m upstream from the Marston Diversion Dam--1996

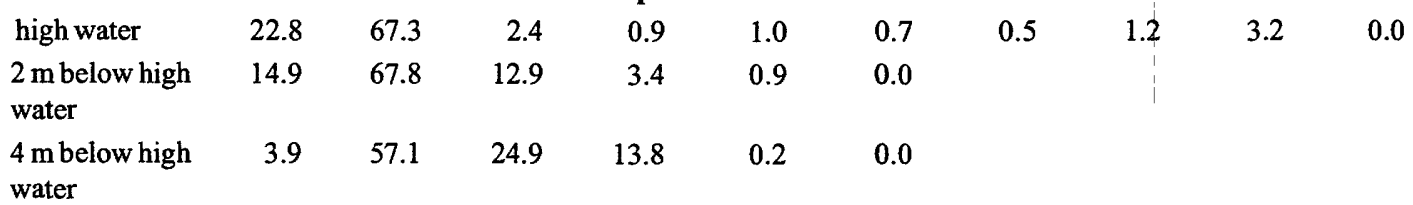

Sediment collected $\sim \mathbf{5 0 0}$ m upstream from the Marston Diversion Dam--1996

high water

$\begin{array}{lllllll}7.0 & 71.9 & 16.3 & 3.4 & 1.3 & 0.1 & 0.0\end{array}$




\section{Table 7.3. Metals associated with hillslope source material and fire-related bed sediments}

in Strontia Springs Reservoir

[ See fig. 7.3 for profile of fire-related sediments in the delta in Strontia Springs Reservoir; see fig. 7.4 for profile of Core 4B; m, meter; g, gram; all concentrations are in micrograms per gram; na, not available. Buffalo River Standard is National Institute of Standards and Technology standard reference material 2704.]

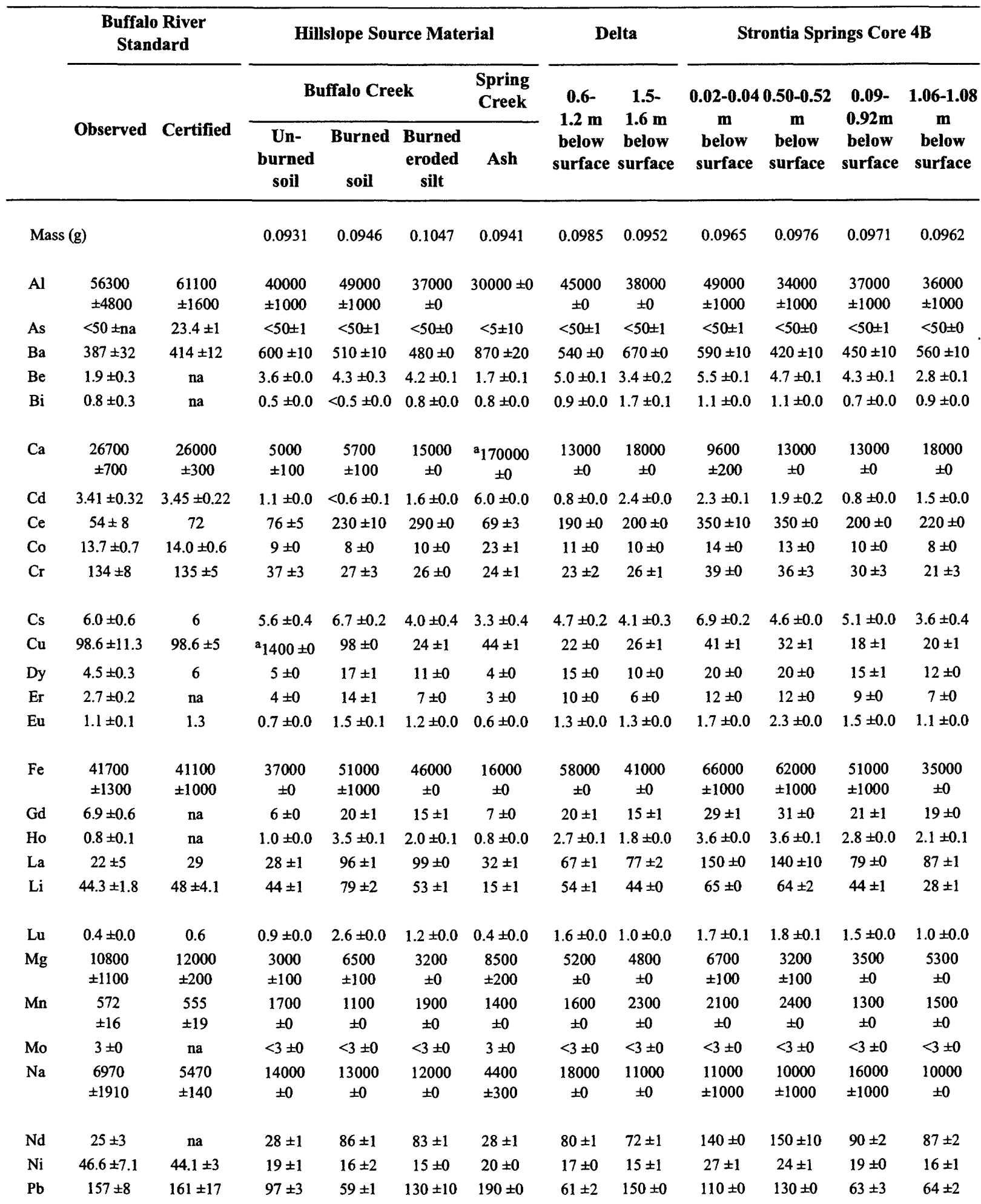


Table 7.3. (Continued) Metals associated with hillslope source material and fire-related bed sediments in Strontia Springs Reservoir

\begin{tabular}{|c|c|c|c|c|c|c|c|c|c|c|c|c|}
\hline & \multicolumn{2}{|c|}{$\begin{array}{l}\text { Buffalo River } \\
\text { Standard }\end{array}$} & \multicolumn{4}{|c|}{ Hillslope Source Material } & \multicolumn{2}{|c|}{ Delta } & \multicolumn{4}{|c|}{ Strontia Springs Core 4B } \\
\hline & \multirow[b]{2}{*}{ Observed } & \multirow[b]{2}{*}{ Certified } & \multicolumn{3}{|c|}{ Buffalo Creek } & \multirow{2}{*}{$\begin{array}{c}\begin{array}{c}\text { Spring } \\
\text { Creek }\end{array} \\
\text { Ash }\end{array}$} & \multirow{2}{*}{$\begin{array}{c}\text { 0.6- } \\
1.2 \mathrm{~m} \\
\text { below } \\
\text { surface }\end{array}$} & \multirow{2}{*}{$\begin{array}{c}1.5- \\
1.6 \mathrm{~m} \\
\text { below } \\
\text { surface }\end{array}$} & \multirow{2}{*}{\begin{tabular}{|c|}
$\mathbf{0 . 0 2 - 0 . 0 4}$ \\
m \\
below \\
surface
\end{tabular}} & \multirow{2}{*}{$\begin{array}{c}\mathbf{0 . 5 0 - 0 . 5 2} \\
\mathrm{m} \\
\text { below } \\
\text { surface }\end{array}$} & \multirow{2}{*}{$\begin{array}{c}\text { 0.09- } \\
0.92 \mathrm{~m} \\
\text { below } \\
\text { surface }\end{array}$} & \multirow{2}{*}{$\begin{array}{c}\text { 1.06-1.08 } \\
\text { below } \\
\text { surface }\end{array}$} \\
\hline & & & $\begin{array}{c}\text { Un- } \\
\text { burned } \\
\text { soil }\end{array}$ & $\begin{array}{c}\text { Burned } \\
\text { soil }\end{array}$ & $\begin{array}{c}\text { Burned } \\
\text { eroded } \\
\text { silt }\end{array}$ & & & & & & & \\
\hline $\operatorname{Pr}$ & $5.7 \pm 0.8$ & na & $7 \pm 0$ & $21 \pm 0$ & $22 \pm 0$ & $7 \pm 0$ & $18 \pm 0$ & $18 \pm 0$ & $35 \pm 1$ & $36 \pm 1$ & $21 \pm 0$ & $20 \pm 1$ \\
\hline $\mathbf{R b}$ & $57 \pm 21$ & 100 & $62 \pm 1$ & $130 \pm 10$ & $37 \pm 2$ & $63 \pm 0$ & $74 \pm 1$ & $39 \pm 0$ & $64 \pm 2$ & $24 \pm 0$ & $38 \pm 1$ & $69 \pm 1$ \\
\hline $\mathrm{Sb}$ & $3.9 \pm 0.3$ & $3.79 \pm 0.15$ & $0.9 \pm 0.1$ & $<0.8 \pm 0.0$ & $1.0 \pm 0.1$ & $1.7 \pm 0.1$ & $<0.8 \pm 0.1$ & $1.3 \pm 0.0$ & $1.0 \pm 0.1$ & $1.1 \pm 0.1$ & $<0.8 \pm 0.0$ & $0.8 \pm 0.1$ \\
\hline $\mathrm{Se}$ & $5 \pm 1$ & $1.12 \pm 0.05$ & $5 \pm 1$ & $5 \pm 1$ & $4 \pm 0$ & $5 \pm 1$ & $5 \pm 0$ & $4 \pm 1$ & $7 \pm 1$ & $6 \pm 1$ & $6 \pm 1$ & $4 \pm 1$ \\
\hline $\mathrm{SiO}_{2}$ & $\begin{array}{l}665000 \\
\pm 66000\end{array}$ & $\begin{array}{c}622000 \\
\pm 3000\end{array}$ & $\begin{array}{c}640000 \\
\pm 0\end{array}$ & $\begin{array}{c}600000 \\
\pm 0\end{array}$ & $\begin{array}{l}560000 \\
\pm 10000\end{array}$ & $\begin{array}{l}280000 \\
\pm 10000\end{array}$ & $\begin{array}{c}690000 \\
\pm 0\end{array}$ & $\begin{array}{l}530000 \\
\pm 10000\end{array}$ & $\begin{array}{l}540000 \\
\pm 10000\end{array}$ & $\begin{array}{l}510000 \\
\pm 10000\end{array}$ & $\begin{array}{l}610000 \\
\pm 10000\end{array}$ & $\begin{array}{c}340000 \\
\pm 0\end{array}$ \\
\hline $\mathrm{Sm}$ & $5.6 \pm 0.6$ & 6.7 & $6 \pm 0$ & $18 \pm 1$ & $16 \pm 0$ & $6 \pm 0$ & $18 \pm 0$ & $14 \pm 0$ & $29 \pm 0$ & $30 \pm 0$ & $20 \pm 0$ & $17 \pm 0$ \\
\hline $\mathrm{Sr}$ & $120 \pm 9$ & 130 & $94 \pm 2$ & $110 \pm 0$ & $95 \pm 2$ & $950 \pm 20$ & $96 \pm 1$ & $120 \pm 0$ & $120 \pm 0$ & $80 \pm 1$ & $83 \pm 0$ & $110 \pm 0$ \\
\hline $\mathrm{Tb}$ & $0.8 \pm 0.1$ & $\mathrm{na}$ & $0.8 \pm 0.0$ & $2.7 \pm 0.0$ & $2.0 \pm 0.0$ & $0.8 \pm 0.0$ & $2.6 \pm 0.1$ & $1.8 \pm 0.1$ & $3.6 \pm 0.0$ & $3.8 \pm 0.0$ & $2.7 \pm 0.1$ & $2.1 \pm 0.0$ \\
\hline $\mathrm{Te}$ & $0.2 \pm 0.1$ & na & $0.3 \pm 0.1$ & $0.1 \pm 0.1$ & $0.2 \pm 0.0$ & $0.4 \pm 0.1$ & $0.2 \pm 0.1$ & $0.2 \pm 0.1$ & $0.3 \pm 0.0$ & $0.4 \pm 0.1$ & $0.2 \pm 0.0$ & $0.1 \pm 0.1$ \\
\hline Th & $7.9 \pm 0.9$ & 9.2 & $14 \pm 0$ & $53 \pm 2$ & $36 \pm 0$ & $8.4 \pm 0.1$ & $17 \pm 0$ & $17 \pm 0$ & $38 \pm 0$ & $40 \pm 0$ & $28 \pm 1$ & $16 \pm 0$ \\
\hline $\mathrm{Ti}$ & $\begin{array}{l}4570 \\
\pm 130\end{array}$ & $\begin{array}{l}4570 \\
\pm 180\end{array}$ & $\begin{array}{c}7400 \\
\pm 0\end{array}$ & $\begin{array}{c}11000 \\
\pm 0\end{array}$ & $\begin{array}{c}5500 \\
\pm 0\end{array}$ & $\begin{array}{l}2100 \\
\pm 100\end{array}$ & $\begin{array}{c}6400 \\
\pm 0\end{array}$ & $\begin{array}{c}4900 \\
\pm 0\end{array}$ & $\begin{array}{c}6400 \\
\pm 0\end{array}$ & $\begin{array}{c}6500 \\
\pm 0\end{array}$ & $\begin{array}{c}6600 \\
\pm 0\end{array}$ & $\begin{array}{c}3400 \\
\pm 0\end{array}$ \\
\hline $\mathrm{TI}$ & $\begin{array}{l}1.00 \\
\pm 0.05\end{array}$ & $\begin{array}{l}1.06 \\
\pm 0.07\end{array}$ & $\begin{array}{l}0.88 \\
\pm 0.02\end{array}$ & $\begin{array}{l}1.00 \\
\pm 0.00\end{array}$ & $\begin{array}{c}0.89 \\
\pm 0.02\end{array}$ & $\begin{array}{c}0.50 \\
\pm 0.02\end{array}$ & $\begin{array}{c}0.98 \\
\pm 0.03\end{array}$ & $\begin{array}{c}0.72 \\
\pm 0.02\end{array}$ & $\begin{array}{c}1.10 \\
\pm 0.00\end{array}$ & $\begin{array}{c}1.10 \\
\pm 0.00\end{array}$ & $\begin{array}{c}0.86 \\
\pm 0.02\end{array}$ & $\begin{array}{c}0.51 \\
\pm 0.03\end{array}$ \\
\hline $\mathrm{Tm}$ & $0.3 \pm 0.0$ & na & $0.6 \pm 0.0$ & $2.2 \pm 0.0$ & $1.0 \pm 0.0$ & $0.4 \pm 0.0$ & $1.4 \pm 0.1$ & $0.9 \pm 0.0$ & $1.6 \pm 0.1$ & $1.6 \pm 0.0$ & $1.4 \pm 0.0$ & $1.0 \pm 0.0$ \\
\hline U & $3.2 \pm 0.1$ & $3.13 \pm 0.13$ & $5.5 \pm 0.0$ & $9.1 \pm 0.1$ & $6.1 \pm 0.0$ & $2.2 \pm 0.1$ & $8.3 \pm 0.0$ & $9.7 \pm 0.4$ & $9.1 \pm 0.0$ & $11.0 \pm 0.0$ & $7.0 \pm 0.1$ & $7.2 \pm 0.0$ \\
\hline v & $90 \pm 3$ & $95 \pm 4$ & $54 \pm 1$ & $44 \pm 0$ & $44 \pm 1$ & $34 \pm 2$ & $36 \pm 0$ & $41 \pm 1$ & $56 \pm 1$ & $60 \pm 1$ & $45 \pm 2$ & $25 \pm 1$ \\
\hline W & $3.3 \pm 0.4$ & na & $4.2 \pm 0.2$ & $4.8 \pm 0.4$ & $3.5 \pm 0.2$ & $3.8 \pm 0.2$ & $3.4 \pm 0.0$ & $2.8 \pm 0.2$ & $5.3 \pm 0.2$ & $5.3 \pm 0.4$ & $4.1 \pm 0.2$ & $2.1 \pm 0.1$ \\
\hline $\mathrm{Y}$ & $20 \pm 2$ & na & $24 \pm 0$ & $89 \pm 3$ & $49 \pm 0$ & $23 \pm 0$ & $65 \pm 0$ & $48 \pm 1$ & $89 \pm 2$ & $91 \pm 0$ & $70 \pm 0$ & $55 \pm 0$ \\
\hline $\mathrm{Yb}$ & $2.6 \pm 0.2$ & 2.8 & $6 \pm 0$ & $17 \pm 0$ & $8 \pm 0$ & $2 \pm 0$ & $10 \pm 0$ & $7 \pm 0$ & $12 \pm 0$ & $12 \pm 0$ & $10 \pm 0$ & $7 \pm 0$ \\
\hline $\mathrm{Zn}$ & $442 \pm 15$ & $438 \pm 12$ & $480 \pm 10$ & $200 \pm 10$ & $280 \pm 0$ & $230 \pm 0$ & $270 \pm 0$ & $290 \pm 10$ & $470 \pm 10$ & $360 \pm 0$ & $240 \pm 10$ & $230 \pm 10$ \\
\hline $\mathrm{Zr}$ & $354 \pm 42$ & 300 & $1000 \pm 10$ & $1300 \pm 0$ & $580 \pm 0$ & $140 \pm 0$ & $1300 \pm 0$ & $430 \pm 10$ & $390 \pm 0$ & $330 \pm 0$ & $950 \pm 10$ & $440 \pm 10$ \\
\hline
\end{tabular}

\footnotetext{
${ }^{a}$ Analytical procedures were rechecked and these values are correct but possible contamination during sampling would require additional analysis of replicate samples to verify these values.
} 


\section{References}

Abrahams, A. D., Gang, Li, and Parsons, A. J., 1996, Rill hydraulics on a semiarid hillslope, southern Arizona: Earth Surface Processes and Landforms, 21, 35-47.

Blair, R. W., Jr., 1976, Weathering and geomorphology of the Pikes Peak Granite in the southern Rampart Range, Colorado, in Epis, R. C. and Weimer, R. J. (eds.) Professional Contributions of Colorado School of Mines: Studies in Colorado Field Geology, 8, 68-72.

Borland, W. M., 1978, Study of sedimentation problems associated with the diversion of municipal raw water from the South Platte River in Platte Canyon approximately 25 miles south west of the city of Denver, Colorado, report submitted to Denver Water Department, Exhibit No. 14., 6 pp, Appendices.

Bovis, M. J., 1974, Rates of soil movement in the Front Range, Boulder County, Colorado: Boulder, University of Colorado, Department of Geography, unpublished $\mathrm{Ph}$. D. dissertation, 235 p.

Brown, J. A. H., 1972, Hydrologic effects of a brushfire in a catchment in south-eastern New South Wales: Journal of Hydrology, 15, 77-96.

Brown, P. M., Kaufmann, M. R., and Shepperd, W. D., 1999, Long-term, landscape patterns of past fire events in a montane ponderosa pine forest of central Colorado: Landscape Ecology, $14,513-532$.

Bruggink, Jeff, Bohon, Denny, Clapsaddle, Casey, Lovato, Daniel and Hill, John, 1998, Buffalo Creek Burned Area Emergency Rehabilitation Final Report: U. S. Department of Agriculture, Forest Service, $22 \mathrm{p}$.

Burrows, R. L., Emmett, W. W., and Parks, Bruce, 1981, Sediment transport in the Tanana River near Fairbanks, Alaska, 1977-79: U.S. Geological Survey Water-Resources Investigations $81-20,56 \mathrm{p}$.

Colorado Climate Center, 2001, http:Ilulysses.atmos.colostate.edu.

Connaughton, C. A., 1938, Erosion on the National Forests of Colorado, Eastern Wyoming and Western South Dakota, Rocky Mountain Forest and Range Experiment Station: U. S. Department of Agriculture, Forest Service, $68 \mathrm{p}$.

Cowan, W. L., 1956, Estimating hydraulic roughness coefficients: Agricultural Engineering, 37 (7), 473-475.

Dalrymple, Tate, and Benson, M. A., 1967, Measurement of peak discharge by the slope-area method: U. S. Geological Survey Techniques of Water-Resources Investigations, Book 3, Chapter A2, $12 \mathrm{p}$.

DeBano, L. F., 1969, Observations on water-repellent soils in western United States, in DeBano, L. F. and Letey, J. (eds.), Water-repellent Soils, Proceedings of the Symposium of Waterrepellent Soils, May 6-10, 1968: University of California, Riverside, 17-29.

DeBano, L.F., Dunn, P. H., and Conrad, C. E., 1977, Fire's effect on physical and chemical properties of chaparral soils: U. S. Department of Agriculture, Forest Service, General Technical Report WO-3, 65-74.

Dietrich, W. E., 1982, Settling velocity of natural particles: Water Resources Research, 18 (6), 1615-1626.

Doehring, D. O., 1968, The effect of fire on geomorphic processes in the San Gabriel Mountains, California, in Parker, R. B. (ed.), Contributions to Geology: Laramie, University of Wyoming, 43-65.

Druffel, Leroy, Emmett, W. W., Schneider, V. R., and Skinner, J. V., 1976, Laboratory hydraulic calibration of the Helley-Smith bedload sediment sampler: U. S. Geological Survey OpenFile Report 76-752, $63 \mathrm{p}$. 
Edwards, T. K. and Glysson, G. D., 1988, Field methods for measurement of fluvial sediment: U.S. Geological Survey Open-File Report 86-531, 118 p.

Elliot, W. J., Liebenov, A. M., Laflen, J. M., and Kohl, K. D., 1989, A compendium of soil erodibility data from WEPP cropland soil field erodibility experiment 1987 \& 88, The Ohio State University and U. S. Department of Agriculture, Agricultural Research Station, August 1989: West Lafayette, Ind, Purdue University, NSERL Report No. 3, 317 p.

Elliott, J. G., 1999, Estimation of fire/flood chronology from alluvial fan stratigraphy in the Buffalo Creek watershed, Colorado: Geological Society of America Abstracts with Programs, 31 (7), A-441.

Elliott, J. G. and Parker, R. S., 2001, Developing a post-fire chronology and recurrence probability from alluvial stratigraphy in the Buffalo Creek watershed, Colorado, USA: Hydrological Processes, 15, 3039-3051.

Emmett, W. W., 1980, A field calibration of the sediment-trapping characteristics of the HelleySmith bedload sampler: U. S. Geological Survey Professional Paper 1139, 28 p.

Fitzhugh, R., 1992, Construction of simple surface runoff sampler. WRD Instrument News (Department of the Interior, U.S. Geological Survey, Water Resources Division), 58, p.1 and p.4.

Fulton, R. A., 1999, Sensitivity of WSR-88D rainfall estimates to the rain-rate threshold and rain gage adjustment-a flash flood case study: Weather Forecasting, 14, 604-624.

Gerlach, T., 1967, Hillslope troughs for measuring sediment movement: Revue Geomorphologie Dynamique, 17(4), 173-174.

Gilbert, G. K., 1914, The transportation of debris by running water: U. S. Geological Survey Professional Paper 86, 263 p.

Giovannini, G., Lucchesi, S., and Cervelli, S., 1983, Water repellent substances and aggregate stability in hydrophobic soil: Soil Science, 135(2), 110-113.

Gonzalez, Mark A. and Hunt, Emily P., 1999, Fire-induced deposition and fan chronology; Spring Creek, Colorado: Geological Society of America Abstracts with Programs, 31 (7), A-441.

Grant, D. M., 1991, ISCO open channel flow measurement handbook: Lincoln, Neb., ISCO Environmental Division, $356 \mathrm{p}$.

Guy, H. P., 1969, Laboratory theory and methods for sediment analysis: U. S. Geological Survey Techniques of Water-Resources Investigations, book 5, chap. C1, $58 \mathrm{p}$.

Hayes, H. C., 1993, Metal associations in suspended sediments and bed sediment for the Mississippi River: Golden, Colorado School of Mines, Dept. of Chemistry and Geochemistry, Masters thesis, $131 \mathrm{p}$.

Henz, J. F., 1998, The Buffalo Creek flash flood of July 12, 1996-a reconstruction of rainfall and meteorology: Denver, Colo., Henz Meteorological Services, unpublished report, 28 p., 1 appendix.

Hershfield, D. M., 1961, Rainfall frequency atlas of the United States for duration from 30 minutes to 24 hours and return periods from 1 to 100 years: U.S. Department of Commerce, Technical Paper No. 40, 107 p.

Horowitz, A. J., 1991, A primer on sediment-trace element chemistry: Chelsea, Mich., Lewis Publishers, $136 \mathrm{p}$.

Horton, R. E., 1945, Erosional development of streams and their drainage basins-hydrophysical approach to quantitative morphology: Bulletin Geological Society of America, 56, 275-370.

Hubbell, D. W., Stevens, H. H. Jr., Skinner, J. V., and Beverage, J. P., 1986, Laboratory data on coarse-sediment transport for bedload-sampler calibrations: U. S. Geological Survey WaterSupply Paper 2299, 31 p. 
Isherwood, D. and Street, A. 1976, Biotite-induced grüssification of the Boulder Creek Granodiorite, Boulder County, Colorado: Geological Society of America Bulletin, 87(3), 366-370.

Jack, J. G., 1900, Pikes Peak, Plum Creek and South Platte Reserves in U. S. Geological Survey, Twentieth Annual Report of the United States Geological Survey: Washington, Government Printing Office, 39-115.

Jarrett, R. D., 1990, Paleohydrology used to define the spatial occurrence of floods: Geomorphology, 3, 181-195.

Jarrett, R. D., 2001, Paleohydrologic estimates of convective rainfall in the Rocky Mountains, in Symposium on Precipitation Extremes-Prediction, Impacts, and Responses, January 14-18, Albuquerque, N. Mex.: Boston, Mass., American Meteorological Society, p. J40-J43.

Kaufmann, M. R., Regan, C. M., and Brown, P. M., 2000a, Heterogeneity in ponderosa pine/Douglas-fir forests-age and structure in unlogged and logged landscapes of Central Colorado: Canadian Journal of Forest Research, 30 (5), 698-711.

Kaufmann, M. R.; Huckaby, Laurie, and Gleason, Paul, 2000b, Ponderosa pine in the Colorado Front Range-long historical fire and tree recruitment intervals and a case for landscape heterogeneity, in Neuenschwander, Leon F. and Ryan, Kevin C., (tech. eds.) Crossing the Millennium--Integrating Spacial Technologies and Ecological Principles for a New Age in Fire Management, Proceedings from the Joint Fire Sciences Conference and Workshop: Boise, Idaho, University of Idaho and the International Association of Wildland Fire, 153-160.

Krammes, J. S., 1960, Erosion from mountain side slopes after fire in southern California: U. S. Department of Agriculture, Forest Service, Pacific Southwest Forest and Range Experiment Station Research Note 171,7 p.

Krammes, J. S., 1965, Seasonal debris movement from steep mountainside slopes in southern California, in Federal Interagency Sedimentation Conference: U. S. Department of Agriculture Miscellaneous Publications 970, 85-89.

Krammes, J. S. and Rice, R. M., 1963, Effect of fire on the San Dimas Experimental Forest: Arizona Watershed Symposium, Phoenix, Sept. 18, 1963, Proceedings 7th Annual Meeting, 3134.

Krumbein, W. C., 1934, Size frequency distributions of sediments: Journal of Sedimentary Petrology, 4, 65-77.

Lekach, J. and Schick, A. P., 1983, Evidence for transport of bedload in waves-analysis of fluvial sediment samples in a small upland stream channel: Catena, 10, 267-279.

Lekach, J., Schick, A. P., and Schlesinger, A., 1992, Bedload yield and in-channel provenance in a flash-flood fluvial system, in Billi P., Hey R. D., Thorne, C. R. and Tacconi, P. (eds.), Dynamics of Gravel-bed Rivers: New York, John Wiley \& Sons, Chap. 27, 537-554.

Leopold, L. B., Wolman, M. G., and Miller, J. P., 1964, Fluvial Processes in Geomorphology: San Francisco, Calif., W. H. Freeman and Co., 522 p.

Mackay, S. M. and Cornish, P. M., 1982, Effects of wildfire and logging on the hydrology of small catchments near Eden, N. S. W., in The First National Symposium on Forest Hydrology: Melbourne, Australia, Institute of Engineers, 111-117.

Martin, D. A. and Moody, J. A., 2001, The flux and particle-size distribution of sediment collected in hillslope traps after a Colorado wildfire: Federal Interagency Sedimentation Conference, 7th, Reno, Nev., March 25-29, 2001, Proceedings, III-40 to III-47.

Meade, R. H., and Stevens, H. H., Jr., 1990, Strategies and equipment for sampling suspended sediment and associated toxic chemicals in large rivers-with emphasis on the Mississippi River: Science of the Total Environment, 97/97, 125-135.

Milhous, R. T., 1973, Sediment transport in a gravel-bottomed stream: Corvallis, Oregon State University, Ph. D. thesis, 232 p. 
Miller, J. F., Frederick, R. H., and Tracey, R. J., 1973, Precipitation-frequency atlas of the western United States, Volume III-Colorado: National Oceanic and Atmospheric Administration, National Weather Service, $67 \mathrm{p}$.

Montgomery, D. R., and Dietrich, W. E., 1989, Source areas, drainage density, and channel initiation: Water Resources Research, 25(8), 1907-1918.

Moody, J. A., 2001, Sediment transport regimes after a wildfire in steep mountainous terrain, Federal Interagency Sedimentation Conference, 7th, Reno, Nev., March 25-29, 2001, Proceedings, $\mathrm{X}-41$ to $\mathrm{X}-48$.

Moody, J. A. and Meade, R. H., 1990, Channel changes at cross sections of the Powder River between Moorhead and Broadus, Montana, 1975-88: U.S. Geological Survey Open-File Report 89-407, $252 \mathrm{p}$.

Moody, J. A. and Meade, R. H., 1993, Hydrologic and sedimentologic data collected during four cruises at high water on the Mississippi River and some of its tributaries, March 1989-June 1990: U. S. Geological Survey Open-File Report 92-651, 225 p.

Moore, I. D. and Foster, G. R., 1990, Hydraulics and overland flow, in Anderson, M. G. and Burt, T. P. (eds.), Process Studies in Hillslope Hydrology, Chapter 7: New York, John Wiley \& Sons Ltd, 215-254.

Moore, Randy, 1992, Soil Survey of Pike National Forest, Eastern Part, Colorado, Parts of Douglas, El Paso, Jefferson, and Teller Counties: United States Department of Agriculture, Forest Service and Soil Conservation Service, $106 \mathrm{p}$.

Morris, S. E., 1983, The surficial debris cascade and hillslope evolutionary tendencies in the Colorado Front Range foothills: Boulder, University of Colorado, Department of Geography, Ph. D. dissertation, $141 \mathrm{p}$.

Morris, S. E. and Moses, T. A., 1987, Forest fire and the natural soil erosion regime in the Colorado Front Range: Annals of the Association of American Geographers, 77(2), 245-254.

Nakagawa, Hiroji, Tsujimoto, Tetsuro, and Shimizu, Yoshihiko, 1991, Turbulent flow with small relative submergence, in Armanini, A. and DiSilvio, G. (eds.), Lecture Notes in Earth Sciences, Fluvial Hydraulics of Mountain Regions: New York, Springer-Verlag, 33-44.

Nash, J. E., 1958, The form of the instantaneous unit hydrograph: International Association of Scientific Hydrology, III(45), 114-121.

Nicholas, A. P., Ashworth, P. J., Kirkby, M. J., Macklin, M. G., and Murray, T., 1995, Sediment slugs-large-scale fluctuations in fluvial sediment transport rates and storage volumes:

Progress in Physical Geography, 19(4), 500-519.

Paola, Chris, and Seal, Rebecca, 1995, Grain size patchiness as a cause of selective deposition and downstream fining: Water Resources Research, 31, 1395-1407.

Posada, L. G., 1995, Transport of sands in deep rivers: Fort Collins, Colorado State University, $\mathrm{Ph}$. D. thesis, $158 \mathrm{p}$.

Pizzuto, J., 1995, Downstream fining in a network of gravel rivers: Water Resources Research, $31,753-759$.

Rantz, S. E., and others, 1982, Measurement and computation of streamflow, Volume 1. Measurement of stage and discharge: U. S. Geological Survey Water-Supply Paper 2175, 284 p.

Renard, K. G., Foster, G. R., Weesies, G. A. McCool, D. K., and Yoder, D. C., 1997, Predicting Soil Erosion by Water-A Guide to Conservation Planning With the Revised Universal Soil Loss Equation (RUSLE): U.S. Department of Agriculture, Agriculture Handbook No. 703, $404 \mathrm{p}$.

Ryan, S.E. and Porth, L.S., 1999, A field comparison of three pressure-difference bedload sam- 
plers: Geomorphology, 30, 307-322.

Shaw, J., and Kellerhals, R., 1982, The composition of recent alluvial gravels in Alberta river beds: Edmonton, Alberta Research Council, Bulletin 41, $151 \mathrm{p}$.

Sinclair, J. D. and Hamilton, E. L., 1955, Streamflow reactions of a fire-damaged watershed: American Society of Civil Engineers, Hydraulics Division, 81, Separate No. 629, 1-17.

Steen, H. K., 1991, The U. S. Forest Service--A History, Third printing: Seattle, University of Washington Press, $356 \mathrm{p}$.

Strahler, A. N., 1952, Hypsometric (area-altitude) analysis of erosional topography: Geological Society of America Bulletin, 63, 1117-1142.

Suszka, Lechostaw, 1991, Modification of transport rate formula for steep channels, in Armanini, A., and DiSilvio, G. (eds.), Lecture Notes in Earth Sciences, Fluvial Hydraulics of Mountain Regions: New York, Springer-Verlag, 59-70.

Troutman, B. M., 1982, An analysis of input errors in precipitation-runoff models using regression with errors in the independent variables: Water Resources Research, 18(4), 947-964.

Tsujimoto, Tesuro, 1991, Bed-load transport in steep channels, in Armanini, A. and DiSilvio, G. (eds.), Lecture Notes in Earth Sciences, Fluvial Hydraulics of Mountain Regions: New York, Springer-Verlag, 89-102.

U.S. Forest Service, 1995, Integrated Resource Training Guide: Denver, Colo., U.S. Department of Agriculture Forest Service, Rocky Mountain Region, $600 \mathrm{p}$.

U.S. Forest Service, 1996, Archive of post-fire and post-flood photographs from Buffalo and Spring Creek watersheds taken after the Buffalo Creek Fire: Morrison, Colo., U.S. Department of Agriculture Forest Service, South Platte Ranger District.

U.S. Geological Survey, 1990, Programs and plans--Policy and guidelines for the collection and publication of bedload data: U. S. Geological Survey, Office of Surface Water Technical Memorandum No. 90.08, 15 p.

U.S. Geological Survey, 1997, Water-Resources Data for Colorado, Water Year 1997: U. S. Geological Survey Water-Data Report CO-97-1, 513 p.

, 1998,Water-Resources Data for Colorado, Water Year 1998: U. S. Geological Survey Water-Data Report CO-98-1, $451 \mathrm{p}$. , 1999,Water-Resources Data for Colorado, Water Year 1999: U. S. Geological Survey Water-Data Report CO-99-1, 499 p. , 2000,Water-Resources Data for Colorado, Water Year 2000: U. S. Geological Survey Water-Data Report CO-00-1, $498 \mathrm{p}$.

Welter, S. P., 1995, Topographic influences on erosion and soil development in hollows of the Rampart Range, Colorado: Boulder, University of Colorado, Department of Geography, $\mathrm{Ph}$. D. dissertation, $263 \mathrm{p}$.

Williams, G. P. and Rosgen, D. L., 1989, Measured total sediment loads (suspended loads and bedloads) for 93 United States streams: U. S. Geological Survey Open-File Report 89-67, $128 \mathrm{p}$.

Yates, David, Warner, T. T., and Leavesley, G. H., 2000, Prediction of a flash flood in complex terrain, Part 2--A comparison of flood discharge simulations using rainfall input from radar, a dynamic model, and an automated alogorithmic system: Journal Applied Meteorology, 39, 815-825. 


\section{Appendices}




\section{Appendix 1. Format of rill files}

[Data are on the accompanying CD in directory Rill. Data file names have the form mnXmmmm.dat, where $\mathrm{mn}$ is the survey number; $\mathrm{X}$ stands for $\mathrm{A}, \mathrm{B}$, or $\mathrm{C}$; and mmmm is the cross-section number; the value of mmmm is listed under the Rill column in this table. In the data file, column 1 is the distance from center of left bank pin in meters; column 2 is the arbitrary elevation in meters]

\begin{tabular}{|c|c|c|c|c|c|}
\hline \multirow{2}{*}{$\begin{array}{l}\text { Survey } \\
\text { number }\end{array}$} & \multirow[b]{2}{*}{ Date } & \multirow{2}{*}{$\begin{array}{l}\text { Days after } \\
4 \text { June } 1998\end{array}$} & \multicolumn{3}{|c|}{ Rill } \\
\hline & & & $\mathbf{A}$ & B & $\mathrm{C}$ \\
\hline & & & & & \\
\hline \multirow[t]{5}{*}{$\mathrm{r} 01$} & 4 June & 0 & 0000 & 0400 & 1000 \\
\hline & & & 0100 & 0500 & 1100 \\
\hline & & & 0200 & 0600 & 1200 \\
\hline & & & 0300 & 0700 & 1300 \\
\hline & & & 0400 & 0800 & 1400 \\
\hline \multirow[t]{5}{*}{$\mathrm{r} 02$} & 5 August & 62 & 0000 & 0400 & 1000 \\
\hline & & & 0100 & 0500 & 1100 \\
\hline & & & 0200 & 0600 & 1200 \\
\hline & & & 0300 & 0700 & 1300 \\
\hline & & & 0400 & 0800 & 1400 \\
\hline \multirow[t]{5}{*}{$\mathrm{r} 03$} & $21 \& 27$ October & 139,146 & 0000 & 0400 & 1000 \\
\hline & & & 0100 & 0500 & 1100 \\
\hline & & & 0200 & 0600 & 1200 \\
\hline & & & 0300 & 0700 & 1300 \\
\hline & & & 0400 & 0800 & 1400 \\
\hline \multicolumn{6}{|c|}{1999} \\
\hline \multirow[t]{5}{*}{ r04 } & 5 May & 335 & 0000 & 0400 & 1000 \\
\hline & & & 0100 & 0500 & 1100 \\
\hline & & & 0200 & 0600 & 1200 \\
\hline & & & 0300 & 0700 & 1300 \\
\hline & & & 0400 & 0800 & 1400 \\
\hline \multirow[t]{5}{*}{ r05 } & $30 \mathrm{July}^{\mathrm{a}}$ & 421 & 0000 & 0400 & 1000 \\
\hline & & & 0100 & 0500 & 1100 \\
\hline & & & 0200 & 0600 & 1200 \\
\hline & & & 0300 & 0700 & 1300 \\
\hline & & & 0400 & 0800 & 1400 \\
\hline \multicolumn{6}{|c|}{2000} \\
\hline \multirow[t]{5}{*}{ r06 } & 30 May & 725 & 0000 & 0400 & 1000 \\
\hline & & & 0100 & 0500 & 1100 \\
\hline & & & 0200 & 0600 & 1200 \\
\hline & . & & 0300 & 0700 & 1300 \\
\hline & & & 0400 & 0800 & 1400 \\
\hline \multirow[t]{3}{*}{$\mathrm{r} 07$} & 19 November & 898 & 0100 & 0500 & 1100 \\
\hline & & & 0200 & 0600 & 1200 \\
\hline & & & 0300 & 0700 & 1300 \\
\hline
\end{tabular}

\footnotetext{
${ }^{\mathrm{a}}$ Data were collected after an intense rainstorm on 17 July 1999 with 30 -minute intensity of $15-18 \mathrm{~mm} / \mathrm{h}$.
} 


\section{Appendix 2. Coordinates and elevation of reference pins for cross sections of rills on a south-facing hillslope in the Spring Creek watershed}

[Numbers below Cross section are distance of the cross section downstream from the beginning of the rill; the arbitrary coordinates and elevation given here can be converted to UTM coordinates and elevation above sea level by using eq. 5.1-5.3; $\mathrm{m}$, meter]

\begin{tabular}{|c|c|c|c|c|c|c|c|}
\hline \multirow[b]{2}{*}{ Rill } & \multirow[b]{2}{*}{$\begin{array}{l}\text { Cross } \\
\text { section }\end{array}$} & \multicolumn{3}{|c|}{ Left bank pin } & \multicolumn{3}{|c|}{ Right bank pin } \\
\hline & & $\begin{array}{c}\text { North } \\
\text { (m) }\end{array}$ & $\begin{array}{l}\text { East } \\
\text { (m) }\end{array}$ & $\begin{array}{l}\text { Elevation } \\
\text { (m) }\end{array}$ & $\begin{array}{c}\text { North } \\
\text { (m) }\end{array}$ & $\begin{array}{l}\text { East } \\
\text { (m) }\end{array}$ & $\begin{array}{l}\text { Elevation } \\
\text { (m) }\end{array}$ \\
\hline $\begin{array}{l}\text { Rill- } \\
\text { BM1 }\end{array}$ & $\begin{array}{c}1 / 2 \text {-inch } \\
\text { rebar }\end{array}$ & 5257.766 & 3933.390 & 2100.331 & $4360511.747^{\mathrm{a}}$ & $484059.928^{\mathrm{a}}$ & $1979.738^{\mathrm{a}}$ \\
\hline \multirow[t]{5}{*}{$\mathbf{A}$} & 0000 & \multirow{2}{*}{\multicolumn{3}{|c|}{$\begin{array}{l}\text { used just the prism and no rod and could not see } \\
\text { these left bank pins }\end{array}$}} & 5247.034 & 3942.090 & 2097.289 \\
\hline & 0100 & & & & 5246.173 & 3942.520 & 2097.023 \\
\hline & 0200 & 5245.362 & 3943.697 & 2096.686 & 5245.248 & 3942.662 & 2096.690 \\
\hline & 0300 & 5244.394 & 3943.817 & 2096.310 & 5244.292 & 3942.763 & 2096.310 \\
\hline & 0400 & 5243.471 & 3943.930 & 2095.958 & 5243.336 & 3942.880 & 2095.957 \\
\hline \multirow[t]{5}{*}{ B } & 0400 & 5234.046 & 3950.352 & 2091.877 & 5233.981 & 3949.344 & 2091.881 \\
\hline & 0500 & 5233.108 & 3950.360 & 2091.458 & 5233.092 & 3949.365 & 2091.456 \\
\hline & 0600 & 5232.154 & 3950.331 & 2091.003 & 5232.188 & 3949.327 & 2091.007 \\
\hline & 0700 & 5231.249 & 3950.297 & 2090.616 & 5231.196 & 3949.272 & 2090.605 \\
\hline & 0800 & 5230.336 & 3950.346 & 2090.189 & 5230.337 & 3949.311 & 2090.197 \\
\hline \multirow[t]{5}{*}{$\mathrm{C}$} & 1000 & 5221.694 & 3953.370 & 2085.534 & 5221.457 & 3952.415 & 2085.523 \\
\hline & 1100 & 5220.821 & 3953.585 & 2085.114 & 5220.609 & 3952.620 & 2085.115 \\
\hline & 1200 & 5220.023 & 3953.557 & 2084.659 & 5219.680 & 3952.612 & 2084.659 \\
\hline & 1300 & 5219.103 & 3953.972 & 2084.143 & 5218.874 & 3952.862 & 2084.145 \\
\hline & 1400 & 5218.283 & 3954.236 & 2083.672 & 5218.011 & 3953.106 & 2083.676 \\
\hline
\end{tabular}

${ }^{\mathrm{a}}$ For this single reference pin, the values for the left bank pin are the arbitrary coordinates and the values for the right bank are the UTM coordinates 
Appendix 3. Summary of stereo photographs for the two watersheds burned by the Buffalo Creek Fire

[Unless otherwise noted, the U.S. Geological Survey has the photographs]

\begin{tabular}{|c|c|c|c|c|}
\hline Date & Scale & Location & Type & Comment \\
\hline 2 June 1996 & $1: 12,000$ & Buffalo Creek & Color & U.S. Forest Service has the film and U. S. Geo- \\
\hline 2 June 1996 & $1: 12,000$ & Spring Creek & Color & logical Survey has prints and some diapositives. \\
\hline 2 \& 5 August 1996 & $1: 12,000$ & Buffalo Creek & Color & U.S. Forest Service has the film and U. S. Geo- \\
\hline 2\&5 August 1996 & $1: 12,000$ & Spring Creek & Color & logical Survey has prints and some diapositives. \\
\hline 1 June 1997 & $1: 3,000$ & Buffalo Creek & Color & $\begin{array}{l}\text { Five photos upstream from the mouth were cen- } \\
\text { tered over the main channel. }\end{array}$ \\
\hline 1 June 1997 & $1: 3,000$ & Spring Creek & Color & $\begin{array}{l}\text { Six photos upstream from the mouth were cen- } \\
\text { tered over the main channel. }\end{array}$ \\
\hline 17 July 1997 & $1: 3,000$ & Buffalo Creek & Color & $\begin{array}{l}\text { Three photos upstream from the mouth were } \\
\text { centered over the main channel. }\end{array}$ \\
\hline 17 July 1997 & $1: 3,000$ & Spring Creek & Color & $\begin{array}{l}\text { Seven photos upstream from the mouth were } \\
\text { centered over the main channel. }\end{array}$ \\
\hline 8 August 1997 & $1: 3,000$ & Buffalo Creek & Color & $\begin{array}{l}\text { Three photos upstream from the mouth were } \\
\text { centered over the main channel. }\end{array}$ \\
\hline 8 August 1997 & $1: 3,000$ & Spring Creek & Color & $\begin{array}{l}\text { Seven photos upstream from the mouth were } \\
\text { centered over the main channel. }\end{array}$ \\
\hline 6 September 1997 & $1: 3,000$ & Buffalo Creek & Black and white & Two photos were taken at the mouth. \\
\hline 6 September 1997 & $1: 3,000$ & Spring Creek & Black and white & $\begin{array}{l}\text { Photos (44) were taken of the entire main chan- } \\
\text { nel and the upper tributaries. }\end{array}$ \\
\hline 15 October 1997 & $1: 3,000$ & Spring Creek & Color & $\begin{array}{l}\text { Photos (53) were taken of the entire main chan- } \\
\text { nel and the upper tributaries. }\end{array}$ \\
\hline 10 May 1998 & $1: 3,000$ & Spring Creek & Black and white & $\begin{array}{l}\text { Photos (53) were taken of the entire main chan- } \\
\text { nel and the upper tributaries. Some diapositives } \\
\text { were made. }\end{array}$ \\
\hline 20 June 1998 & $1: 3,000$ & Spring Creek & Color positives & $\begin{array}{l}\text { Entire watershed was photographed but only } \\
\text { with } 20 \text { percent overlap and the scale varies } \\
\text { because of relief. }\end{array}$ \\
\hline 15 July 1998 & $1: 12,000$ & Spring Creek & Color & $\begin{array}{l}\text { Two prints and diapositives were obtained } \\
\text { which cover the most of the watershed. }\end{array}$ \\
\hline 15 July 1998 & $1: 12,000$ & Spring Creek & Color & Ten prints were centered over the main channel. \\
\hline
\end{tabular}




\section{Appendix 4. Average arbitrary coordinates and adjustments for reference pins located at either end of cross sections in Spring Creek}

[The coordinate system and elevations are arbitrary but were estimated to be close to true north, true east, and elevation above sea level. The average location of each reference pin is the average of four surveys (May-June, July, August, and SeptemberOctober 1997) and the north and east adjustment are defined by the equations: average north (east) coordinate of left bank pin $=$ survey coordinate + North adjustment (East adjustment); adjustments were interpolated for transects between the cross sections in this table; left bank (LB) and right bank (RB) are defined facing downstream; ns, not resurveyed; bs, backsight; na, does not apply because automatic level, metric tape, and surveying rod method were used; $\mathrm{m}$, meter]

\begin{tabular}{|c|c|c|c|c|c|c|c|c|c|c|c|c|c|c|c|c|c|c|}
\hline \multirow{2}{*}{\multicolumn{2}{|c|}{$\begin{array}{c}\text { Cross } \\
\text { section and } \\
\text { bank }\end{array}$}} & \multicolumn{3}{|c|}{ Average coordinate } & \multicolumn{7}{|c|}{ North adjustment (m) } & \multicolumn{7}{|c|}{ East adjustment (m) } \\
\hline & & $\begin{array}{l}\text { North } \\
\text { N } \\
(\mathrm{m})\end{array}$ & $\begin{array}{c}\text { East } \\
\mathbf{E} \\
(\mathbf{m})\end{array}$ & $\begin{array}{c}\text { Elevation } \\
Z \begin{array}{c}Z \\
\text { (m) }\end{array}\end{array}$ & $\begin{array}{l}\text { May- } \\
\text { June } \\
1997\end{array}$ & $\begin{array}{l}\text { July } \\
1997\end{array}$ & $\begin{array}{l}\text { Aug. } \\
1997\end{array}$ & $\begin{array}{l}\text { Sept.- } \\
\text { Oct. } \\
1997\end{array}$ & $\begin{array}{l}\text { April } \\
\text { May } \\
1998\end{array}$ & $\begin{array}{l}19-21 \\
\text { May } \\
1998\end{array}$ & $\begin{array}{c}1-2 \\
\text { July } \\
1998\end{array}$ & $\begin{array}{c}\text { May- } \\
\text { June } \\
1997\end{array}$ & $\begin{array}{c}\text { July } \\
1997\end{array}$ & $\begin{array}{l}\text { Aug. } \\
1997\end{array}$ & $\begin{array}{l}\text { Sept.- } \\
\text { Oct. } \\
1997\end{array}$ & $\begin{array}{l}\text { April } \\
\text { May } \\
1998\end{array}$ & $\begin{array}{c}19-21 \\
\text { May } \\
1998\end{array}$ & $\begin{array}{c}1-2 \\
\text { July } \\
1998\end{array}$ \\
\hline-2.7 & $-10 \mathrm{~m}$ & 4695.88 & 5215.63 & 1996.30 & \multicolumn{2}{|c|}{ installed later } & -0.00 & $s^{0.00}$ & -0.02 & \multirow{2}{*}{$\begin{array}{l}\text { ns } \\
0.01\end{array}$} & \multirow{2}{*}{$\begin{array}{l}\text { ns } \\
\text { ns }\end{array}$} & \multirow{2}{*}{\multicolumn{2}{|c|}{$\begin{array}{l}\text { installed later } \\
\text { bs }\end{array}$}} & \multirow{2}{*}{$\begin{array}{l}0.02 \\
0.00\end{array}$} & \multirow{2}{*}{$\begin{array}{r}-0.02 \\
0.00\end{array}$} & \multirow{2}{*}{$\begin{array}{l}-0.02 \\
-0.02\end{array}$} & \multirow{2}{*}{$\begin{array}{c}\text { ns } \\
-0.02\end{array}$} & \multirow{2}{*}{$\begin{array}{l}\text { ns } \\
\text { ns }\end{array}$} \\
\hline-2.7 & $\mathrm{RB}$ & 4660.79 & 5179.25 & 1996.78 & 0.00 & -0.03 & \multicolumn{2}{|c|}{ bs } & -0.02 & & & & & & & & & \\
\hline 100 & LB & 4791.02 & 5186.29 & 2000.48 & -0.01 & 0.01 & 0.01 & 0.00 & -0.04 & 0.01 & -0.08 & -0.04 & 0.01 & 0.01 & 0.02 & 0.00 & -0.01 & -0.12 \\
\hline 100 & $\mathrm{RB}$ & 4775.38 & 5151.00 & 2001.16 & -0.01 & 0.01 & 0.01 & 0.00 & 0.03 & 0.01 & -0.03 & -0.04 & 0.01 & 0.01 & 0.02 & 0.02 & 0.04 & -0.08 \\
\hline 187 & LB & 4871.59 & 5142.81 & 2003.84 & 0.06 & 0.01 & 0.00 & -0.07 & -0.02 & bs & -0.08 & -0.01 & -0.06 & 0.00 & 0.05 & 0.09 & bs & -0.12 \\
\hline 187 & $\mathrm{RB}$ & 4848.35 & 5116.39 & 2006.14 & 0.06 & 0.01 & 0.00 & -0.07 & 0.00 & ns & -0.14 & -0.01 & -0.06 & 0.00 & 0.05 & 0.09 & ns & -0.12 \\
\hline 250 & LB & 4909.03 & 5096.56 & 2006.22 & -0.01 & 0.02 & 0.04 & -0.05 & 0.08 & -0.11 & -0.06 & -0.06 & -0.03 & 0.01 & 0.07 & 0.04 & -0.04 & -0.09 \\
\hline 250 & $\mathrm{RB}$ & 4896.70 & 5066.09 & 2006.76 & -0.01 & 0.02 & 0.04 & -0.05 & 0.00 & -0.16 & -0.15 & -0.06 & -0.03 & 0.01 & 0.07 & -0.02 & -0.07 & -0.16 \\
\hline 341 & LB & 4995.62 & 5049.64 & 2010.09 & -0.08 & 0.03 & 0.09 & -0.04 & 0.04 & -0.11 & -0.13 & -0.10 & 0.00 & 0.02 & 0.08 & -0.04 & -0.07 & -0.17 \\
\hline 341 & $\mathrm{RB}$ & 4963.15 & 5018.87 & 2010.18 & -0.08 & 0.03 & 0.09 & -0.04 & 0.05 & -0.15 & -0.14 & -0.10 & 0.00 & 0.02 & 0.08 & -0.05 & -0.07 & -0.21 \\
\hline 393 & LB & 5025.31 & 4997.55 & 2010.98 & -0.10 & 0.03 & 0.10 & -0.03 & 0.01 & -0.16 & -0.22 & -0.12 & -0.03 & 0.04 & 0.11 & 0.00 & -0.07 & -0.15 \\
\hline 393 & $\mathbf{R B}$ & 4988.59 & 4980.54 & 2012.49 & -0.10 & 0.03 & 0.10 & -0.03 & 0.01 & -0.13 & -0.16 & -0.12 & -0.03 & 0.04 & 0.11 & -0.04 & 0.00 & -0.17 \\
\hline 483 & LB & 5062.91 & 492 & 78 & -0.11 & -0.02 & 0.14 & -0.01 & 0.05 & -0.10 & -0.14 & -0.17 & -0.03 & 0.03 & 0.18 & 0.00 & 0.03 & -0.15 \\
\hline 483 & RB & 5029.25 & 4893.57 & 2016.12 & -0.11 & -0.02 & 0.14 & -0.01 & 0.08 & -0.08 & ns & -0.17 & -0.03 & 0.03 & 0.18 & 0.01 & 0.02 & ns \\
\hline 567 & LB & 5109.73 & 4841.46 & 2017.83 & -0.18 & -0.05 & 0.18 & 0.05 & ns & -0.03 & -0.13 & -0.20 & -0.06 & 0.03 & 0.23 & 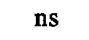 & 0.02 & -0.15 \\
\hline 567 & RB & 5076.78 & 4836.36 & 2019.34 & -0.18 & -0.05 & 0.18 & 0.05 & 0.08 & 0.02 & -0.14 & -0.20 & -0.06 & 0.03 & 0.23 & 0.04 & 0.01 & -0.16 \\
\hline 679 & LB & 5121.81 & 4741.22 & 2022.27 & -0.27 & -0.08 & 0.22 & 0.14 & -0.10 & -0.15 & na & -0.26 & -0.10 & 0.05 & 0.32 & -0.01 & -0.08 & na \\
\hline 679 & $\mathrm{RB}$ & 5104.92 & 4723.55 & 2023.81 & -0.27 & -0.08 & 0.22 & 0.14 & -0.14 & ns & na & -0.26 & -0.10 & 0.05 & 0.32 & -0.03 & ns & \\
\hline 755 & LB & 5149.84 & 4666.00 & 2027.26 & -0.28 & -0.15 & 0.23 & 0.20 & -0.07 & -0.09 & na & -0.26 & -0.13 & 0.05 & 0.33 & -0.05 & -0.04 & na \\
\hline 755 & $\mathrm{RB}$ & 5117.17 & 4656.22 & 2026.69 & -0.28 & -0.15 & 0.23 & 0.20 & -0.08 & -0.03 & na & -0.26 & -0.13 & 0.05 & 0.33 & 0.01 & -0.07 & na \\
\hline 815 & LB & 5162.67 & 4609.94 & 2029.31 & -0.28 & -0.17 & 0.22 & 0.23 & -0.15 & -0.12 & na & -0.31 & -0.13 & 0.06 & 0.38 & -0.01 & -0.09 & na \\
\hline 815 & RB & 5138.82 & 4601.54 & 2030.03 & -0.28 & -0.17 & 0.22 & 0.23 & -0.15 & -0.08 & na & -0.31 & -0.13 & 0.06 & 0.38 & 0.05 & -0.09 & na \\
\hline 905 & LB & 5196.49 & 4521.06 & 42 & -0.33 & -0.19 & 0.26 & 0.26 & -0.09 & -0.11 & na & -0.16 & -0.21 & 0.04 & 0.33 & -0.14 & -0.15 & na \\
\hline 905 & RB & 5171.73 & 4524.04 & 2032.86 & -0.33 & -0.19 & 0.26 & 0.26 & -0.09 & -0.12 & na & -0.16 & -0.21 & 0.04 & 0.33 & -0.12 & -0.14 & na \\
\hline 1006 & LB & 5195.30 & 4422.50 & 2 & -0.40 & -0.19 & 0.25 & 0.34 & -0.10 & -0.13 & na & -0.18 & -0.22 & 0.03 & 0.36 & -0.09 & -0.13 & na \\
\hline 1006 & $\mathbf{R B}$ & 5176.79 & 4420.09 & 2035.88 & -0.40 & -0.19 & 0.25 & 0.34 & -0.06 & -0.08 & na & -0.18 & -0.22 & 0.03 & 0.36 & -0.04 & -0.10 & na \\
\hline 1200 & LB & 5248.49 & 4236.05 & & -0.38 & -0.29 & 0.16 & & -0.05 & -0.05 & Ha & -0.18 & -0.27 & 0.01 & 0.45 & -0.16 & -0.15 & na \\
\hline 1200 & $\mathbf{R B}$ & 5224.36 & 4234.47 & 2043.33 & -0.38 & -0.29 & 0.16 & 0.54 & -0.04 & -0.04 & na & -0.18 & -0.27 & 0.01 & 0.45 & -0.04 & -0.04 & na \\
\hline 1340 & LB & 5219.33 & 4099.82 & 2050.06 & -0.42 & -0.35 & 0.10 & 0.67 & -0.07 & -0.07 & 110 & -0.19 & -0.30 & -0.01 & 0.50 & -0.05 & -0.02 & na \\
\hline 1340 & $\mathbf{R B}$ & 5203.42 & 4101.10 & 2049.66 & -0.42 & -0.35 & 0.10 & 0.67 & -0.04 & -0.04 & na & -0.19 & -0.30 & -0.01 & 0.50 & -0.04 & -0.04 & na \\
\hline 1450 & LB & 5182.56 & 4.26 & 2056.34 & & & 1 & & & & - & & & & & & & \\
\hline 1450 & RB & 5167.17 & 4000.22 & 2056.64 & & f & e & as & pl & Intil & ay 1 & $\mathrm{n}$ & adjustm & ents are 1 & necessary & & & \\
\hline
\end{tabular}




\section{Appendix 5. Average arbitrary coordinates and adjustments for reference pins located at either end of cross sections in Buffalo Creek}

[The coordinate system and elevations are arbitrary and they are not the same as those in Spring Creek. They were estimated to be close to true north, true east, and elevation above sea level. The average location of each reference pin is the average of four surveys (June and July 1997) and the north and east adjustment are defined by the equations: average north (east) coordinate of left bank pin = survey coordinate + North adjustment (East adjustment); adjustments were interpolated for transects between the cross sections in this table; left bank (LB) and right bank (RB) are defined facing downstream; ns, not resurveyed; bs, backsight; $m$, meter]

\begin{tabular}{|c|c|c|c|c|c|c|c|c|c|c|c|c|}
\hline \multirow{2}{*}{\multicolumn{2}{|c|}{$\begin{array}{l}\text { Cross section } \\
\text { and } \\
\text { bank }\end{array}$}} & \multicolumn{3}{|c|}{ Average coordinate } & \multicolumn{4}{|c|}{ North adjustment (m) } & \multicolumn{4}{|c|}{ East adjustment (m) } \\
\hline & & \multirow{2}{*}{$\begin{array}{c}\begin{array}{c}\text { North } \\
\mathbf{N} \\
(\mathrm{m})\end{array} \\
5075.18\end{array}$} & \multirow{2}{*}{$\begin{array}{c}\begin{array}{c}\text { East } \\
\mathbf{E} \\
(\mathbf{m})\end{array} \\
4981.93\end{array}$} & \multirow{2}{*}{$\begin{array}{c}\begin{array}{c}\text { Elevation } \\
\mathbf{Z} \\
(\mathbf{m})\end{array} \\
1999.83\end{array}$} & \multirow{2}{*}{$\begin{array}{l}\text { June } \\
1997 \\
0.02\end{array}$} & \multirow{2}{*}{$\begin{array}{r}\begin{array}{c}\text { July } \\
1997\end{array} \\
-0.02\end{array}$} & \multirow{2}{*}{$\begin{array}{c}\begin{array}{c}\text { August } \\
1997\end{array} \\
-0.01\end{array}$} & \multirow{2}{*}{$\begin{array}{c}\text { May } \\
1998\end{array}$} & \multirow{2}{*}{$\begin{array}{r}\text { June } \\
1997 \\
-0.01\end{array}$} & \multirow{2}{*}{$\begin{array}{c}\begin{array}{c}\text { July } \\
1997\end{array} \\
0.01\end{array}$} & \multirow{2}{*}{$\begin{array}{c}\begin{array}{c}\text { August } \\
1997\end{array} \\
-0.34\end{array}$} & \multirow{2}{*}{$\begin{array}{c}\text { May } \\
1998 \\
\text { bs }\end{array}$} \\
\hline 10 & LB & & & & & & & & & & & \\
\hline 10 & RB & 5069.41 & 5033.23 & 2001.19 & 0.08 & -0.08 & 0.26 & 0.07 & -0.05 & 0.06 & -0.35 & -0.06 \\
\hline 79 & LB & 5005.03 & 4981.31 & 2000.76 & 0.04 & -0.04 & -0.11 & 0.06 & -0.02 & 0.02 & -0.02 & -0.01 \\
\hline 79 & RB & 5004.55 & 5023.87 & 2000.74 & 0.04 & -0.04 & 0.19 & 0.07 & -0.01 & 0.01 & -0.02 & -0.04 \\
\hline 150 & LB & 4944.18 & 4961.33 & 2001.75 & 0.02 & -0.02 & -0.19 & 0.04 & -0.04 & 0.04 & 0.22 & -0.06 \\
\hline 150 & $\mathbf{R B}$ & 4928.40 & 5005.22 & 2002.09 & 0.06 & -0.06 & 0.08 & 0.10 & -0.01 & 0.01 & 0.32 & -0.03 \\
\hline 230 & LB & 4869.27 & 4935.03 & 2004.12 & -0.01 & 0.01 & -0.33 & 0.00 & 0.01 & -0.01 & 0.67 & 0.08 \\
\hline 230 & $\mathbf{R B}$ & 4854.64 & 4974.67 & 2004.82 & -0.01 & 0.01 & -0.12 & 0.04 & 0.01 & -0.01 & 0.72 & 0.05 \\
\hline 300 & LB & 4798.48 & 4922.52 & 2005.03 & -0.01 & 0.01 & -0.39 & 0.00 & -0.02 & 0.02 & 0.98 & 0.12 \\
\hline 300 & RB & 4790.44 & 4951.17 & 2006.25 & -0.01 & 0.01 & -0.26 & 0.02 & 0.00 & 0.00 & 1.00 & 0.10 \\
\hline 391 & LB & 4709.98 & 4899.26 & 2006.65 & -0.01 & 0.01 & -0.52 & 0.00 & -0.05 & 0.05 & 1.35 & 0.12 \\
\hline 391 & $\mathbf{R B}$ & 4702.06 & 4939.00 & 2007.43 & -0.02 & 0.02 & -0.36 & 0.02 & -0.03 & 0.03 & 1.38 & 0.10 \\
\hline 480 & LB & 4622.49 & 4888.95 & 2007.14 & -0.04 & 0.04 & ns & -0.01 & $-0,06$ & 0.06 & ns & 0.10 \\
\hline 480 & RB & 4612.52 & 4930.61 & 2007.74 & -0.05 & 0.05 & -0.41 & 0.02 & -0.06 & 0.06 & 1.61 & 0.06 \\
\hline
\end{tabular}




\section{Appendix 6. UTM coordinates and arbitrary coordinates for selected reference pins near the mouth of Spring Creek}

[The arbitrary coordinate system was estimated to be close to true north, true east, and elevation above sea level. GPS data were collected using a survey grade system (Trimble 4700 Rover and 4800 Base); reference pins are

4-foot long pieces of $1 / 2$-inch rebar driven into the ground at least 0.6 meter and usually 1.0 meter; $\mathrm{m}$, meter]

\begin{tabular}{|c|c|c|c|c|c|c|c|c|}
\hline \multirow[b]{2}{*}{$\begin{array}{c}\text { Cross } \\
\text { section }\end{array}$} & \multicolumn{3}{|c|}{ Arbitrary coordinate } & \multicolumn{3}{|c|}{ UTM coordinate } & \multirow[b]{2}{*}{$\begin{array}{l}\text { Elevation } \\
\text { difference } \\
\text { (m) }\end{array}$} & \multirow[b]{2}{*}{ Comments } \\
\hline & $\begin{array}{c}\text { North } \\
\mathbf{N} \\
(\mathbf{m})\end{array}$ & $\begin{array}{c}\text { East } \\
\mathbf{E} \\
(\mathbf{m})\end{array}$ & $\begin{array}{c}\text { Elevation } \\
\text { Z } \\
(\mathbf{m})\end{array}$ & $\begin{array}{c}\text { North } \\
\mathbf{N}^{\prime} \\
(\mathbf{m})\end{array}$ & $\begin{array}{c}\text { East } \\
\mathbf{E}^{\prime} \\
(\mathbf{m})\end{array}$ & $\begin{array}{c}\text { Elevation } \\
\mathbf{Z}^{\prime} \\
\text { (m) }\end{array}$ & & \\
\hline-2.7 & 4695.885 & 5215.626 & 1996.297 & 4360010.739 & 485365.690 & 1875.181 & 121.116 & $\begin{array}{l}\text { Top of the reference pin at station }-10 \mathrm{~m} \\
\text { located on the left bank about } 4 \mathrm{~m} \text { upstream } \\
\text { from a boulder about } 4 \mathrm{~m} \text { in diameter. The } \\
\text { pin is tall and the elevation less certain so it } \\
\text { was not used to calculate the transformation } \\
\text { between the arbitrary coordinate system } \\
\text { and the UTM coordinate system. }\end{array}$ \\
\hline 100 & 4775.384 & 5150.998 & 2001.160 & $\begin{array}{l}4360087.168 \\
4360087.126\end{array}$ & $\begin{array}{l}485297.541 \\
485297.677\end{array}$ & $\begin{array}{l}1880.114 \\
1880.096\end{array}$ & 121.055 & $\begin{array}{l}\text { Two measurements were made on the top of } \\
\text { the right bank reference pin. The elevation } \\
\text { is the average of the two measurements. }\end{array}$ \\
\hline 755 & 5149.844 & 4666.000 & 2027.258 & 4360438.416 & 484796.199 & 1906.622 & 120.636 & $\begin{array}{l}\text { Top of the left bank reference pin, which is on } \\
\text { the stream side of a } 1.5-2 \mathrm{~m} \text { diameter boul- } \\
\text { der about } 10 \mathrm{~m} \text { from the left edge of the } \\
\text { channel. }\end{array}$ \\
\hline 905 & 5196.494 & 4521.065 & 2031.424 & 4360478.127 & 484649.517 & 1910.801 & 120.623 & $\begin{array}{l}\text { Top of the left bank reference pin, which is in } \\
\text { a clump of willows at the base of the rock } \\
\text { valley wall on the left edge of the channel. }\end{array}$ \\
\hline 905 & 5171.730 & 4524.036 & 2032.861 & 4360453.683 & 484653.520 & 1912.291 & 120.570 & $\begin{array}{l}\text { Top of the right bank reference pin, which is } \\
\text { about } 6 \mathrm{~m} \text { from the right valley edge up in } \\
\text { some vegetation. }\end{array}$ \\
\hline $\begin{array}{l}\text { Rill- } \\
\text { BM1 }\end{array}$ & 5257.766 & 3933.390 & 2100.331 & 4360511.747 & 484059.928 & 1979.738 & 120.593 & $\begin{array}{l}\text { On top of a knoll above where the south-fac- } \\
\text { ing hillslope traps were located opposite the } \\
\text { site of the U. S. Geological Survey stream } \\
\text { gage house. This reference pin is about } 0.1 \\
\mathrm{~m} \text { above the ground. }\end{array}$ \\
\hline 1200 & 5248.487 & 4236.054 & 2043.055 & 4360516.626 & 484362.541 & 1921.828 & 121.227 & $\begin{array}{l}\text { Top of the left bank reference pin, which is } \\
0.3-0.4 \mathrm{~m} \text { above the ground and near a rock } \\
\text { outcrop along the left valley edge. It is } \\
\text { about } 25 \mathrm{~m} \text { downstream from a relatively } \\
\text { large tributary on the left bank. The pin is } \\
\text { tall and the elevation less certain so it was } \\
\text { not used to calculate the transformation } \\
\text { between the arbitrary coordinate system } \\
\text { and the UTM coordinate system. }\end{array}$ \\
\hline 1200 & 5224.360 & 4234.472 & 2043.329 & 4360492.570 & 484361.890 & 1922.719 & 120.610 & $\begin{array}{l}\text { Top of the right bank reference pin, which is } \\
\text { about } 0.2-0.3 \mathrm{~m} \text { above the ground near the } \\
\text { right valley edge in a sand and gravel ter- } \\
\text { race. }\end{array}$ \\
\hline
\end{tabular}




\section{Appendix 7. UTM coordinates for cross-section end points in Spring Creek}

[The arbitrary coordinate system was estimated to be close to true north, true east, and elevation above sea level. UTM coordinates were computed using eqs. 5.1-5.3 in the text which are accurate to the nearest 0.1 $\mathrm{m}$ in horizontal directions and $0.01 \mathrm{~m}$ in elevation; LB, left bank; $\mathrm{RB}$, right bank; pins are 4-foot long pieces of 1/2-inch rebar driven into the ground at least $0.6 \mathrm{~m}$ and usually $1.0 \mathrm{~m} ; \mathrm{m}$, meter]

\begin{tabular}{|c|c|c|c|c|c|c|}
\hline \multirow{2}{*}{$\begin{array}{l}\text { Cross } \\
\text { section }\end{array}$} & \multirow[b]{2}{*}{ Bank } & \multirow[b]{2}{*}{$\begin{array}{c}\text { Station } \\
\text { (m) }\end{array}$} & \multirow[b]{2}{*}{ Marker } & \multicolumn{3}{|c|}{ UTM coordinates } \\
\hline & & & & $\begin{array}{c}\text { North } \\
\text { (m) }\end{array}$ & $\begin{array}{l}\text { East } \\
\text { (m) }\end{array}$ & $\begin{array}{c}\text { Elevation } \\
\text { (m) }\end{array}$ \\
\hline-20 & LB & 0.0 & pin & 4360003.2 & 485383.4 & 1875.07 \\
\hline-20 & RB & 72.8 & pin & 4359959.0 & 485329.6 & 1875.18 \\
\hline-2.7 & LB & -35.0 & $\operatorname{pin}^{1}$ & 4360029.0 & 485382.8 & 1879.26 \\
\hline-2.7 & RB & 40.5 & pin & 4359974.1 & 485331.1 & 1876.00 \\
\hline 30 & LB & 0.0 & pin & 4360038.9 & 485359.5 & 1877.16 \\
\hline 30 & $\mathrm{RB}$ & 43.8 & nail & 4360022.5 & 485318.9 & 1879.31 \\
\hline 50 & LB & 0.0 & pin & 4360052.6 & 485340.9 & 1877.05 \\
\hline 50 & RB & 28.8 & pin & 4360042.9 & 485313.8 & 1877.84 \\
\hline 70 & LB & 0.0 & nail & 4360072.7 & 485341.5 & 1878.48 \\
\hline 70 & RB & 38.1 & nail & 4360060.9 & 485306.2 & 1878.75 \\
\hline 100 & LB & 0.0 & pin & 4360104.4 & 485332.1 & 1879.45 \\
\hline 100 & RB & 38.7 & pin & 4360087.2 & 485297.6 & 1880.16 \\
\hline 140 & LB & 0.0 & pin & 4360139.5 & 485313.7 & 1880.53 \\
\hline 140 & RB & 32.0 & pin & 4360125.4 & 485284.9 & 1880.27 \\
\hline 160 & LB & 0.0 & nail & 4360158.8 & 485299.2 & 1881.39 \\
\hline 160 & $\mathrm{RB}$ & 29.4 & nail & 4360140.2 & 485276.4 & 1881.17 \\
\hline 187 & LB & 0.0 & pin & 4360182.8 & 485284.9 & 1882.76 \\
\hline 187 & $\mathrm{RB}$ & 35.3 & pin & 4360158.4 & 485259.7 & 1884.31 \\
\hline 220 & LB & 0.0 & nail & 4360202.9 & 485258.3 & 1883.80 \\
\hline 220 & $\mathrm{RB}$ & 32.0 & nail & 4360181.0 & 485234.8 & 1883.43 \\
\hline 250 & LB & 0.0 & pin & 4360218.0 & 485237.0 & 1885.38 \\
\hline 250 & $\mathrm{RB}$ & 32.9 & pin & 4360204.3 & 485207.2 & 1885.89 \\
\hline 280 & LB & 0.0 & pin & 4360245.9 & 485219.2 & 1886.78 \\
\hline 280 & $\mathrm{RB}$ & 36.4 & pin & 4360223.4 & 485190.4 & 1885.89 \\
\hline 310 & LB & 0.0 & nail & 4360274.6 & 485198.4 & 1887.48 \\
\hline 310 & $\mathrm{RB}$ & 36.9 & pin & 4360243.2 & 485178.9 & 1886.94 \\
\hline 341 & LB & 0.0 & pin & 4360302.3 & 485186.2 & 1889.23 \\
\hline 341 & $\mathrm{RB}$ & 44.9 & pin & 4360268.4 & 485157.0 & 1889.29 \\
\hline 370 & LB & 0.0 & pin+nail & 4360316.7 & 485158.2 & 1889.60 \\
\hline 370 & RB & 43.0 & nail & 4360281.5 & 485133.4 & 1889.38 \\
\hline 393 & LB & 0.0 & pin & 4360329.5 & 485132.8 & 1890.13 \\
\hline 393 & $\mathrm{RB}$ & 40.5 & nail & 4360292.0 & 485117.5 & 1891.55 \\
\hline 423 & LB & 0.0 & pin & 4360337.8 & 485104.7 & 1891.65 \\
\hline 423 & RB & 36.9 & nail & 4360304.1 & 485089.8 & 1891.68 \\
\hline 453 & LB & 0.0 & $\operatorname{pin}^{2}$ & 4360349.2 & 485078.4 & 1892.57 \\
\hline 453 & $\mathrm{RB}$ & 38.2 & $\operatorname{pin}^{2}$ & 4360316.2 & 485059.8 & 1892.67 \\
\hline 483 & LB & 0.0 & pin & 4360363.5 & 485055.3 & 1894.14 \\
\hline 483 & $\mathrm{RB}$ & 43.8 & pin & 4360328.6 & 485028.8 & 1895.25 \\
\hline 510 & LB & 0.0 & nai & 4360382.7 & 485034.3 & 1895.19 \\
\hline 510 & $\mathrm{RB}$ & 41.2 & pin & 4360351.5 & 485009.4 & 1895.42 \\
\hline 540 & LB & 0.0 & pin & 4360403.6 & 485006.4 & 1898.19 \\
\hline 540 & RB & 41.4 & pin & 4360365.9 & 484989.1 & 1896.96 \\
\hline
\end{tabular}


Appendix 7. (Continued) UTM coordinates for cross-section end points in Spring Creek

\begin{tabular}{|c|c|c|c|c|c|c|}
\hline \multirow{2}{*}{$\begin{array}{c}\text { Cross } \\
\text { section }\end{array}$} & \multirow[b]{2}{*}{ Bank } & \multirow[b]{2}{*}{$\begin{array}{c}\text { Station } \\
\text { (m) }\end{array}$} & \multirow[b]{2}{*}{ Marker } & \multicolumn{3}{|c|}{ UTM coordinates } \\
\hline & & & & $\begin{array}{l}\text { North } \\
\text { (m) }\end{array}$ & $\begin{array}{l}\text { East } \\
\text { (m) }\end{array}$ & $\begin{array}{c}\text { Elevation } \\
\text { (m) }\end{array}$ \\
\hline 567 & $\overline{L B}$ & 0.0 & $\overline{\text { pin }}$ & 4360406.5 & 484973.1 & 1896.94 \\
\hline 567 & RB & 33.5 & pin & 4360373.3 & 484969.5 & 1898.45 \\
\hline 590 & LB & 0.0 & pin & 4360403.1 & 484947.6 & 1898.89 \\
\hline 590 & RB & 28.0 & nail & 4360376.5 & 484949.2 & 1898.44 \\
\hline 620 & LB & 0.0 & pin & 4360403.6 & 484919.2 & 1900.94 \\
\hline 620 & $\mathrm{RB}$ & 32.8 & nail & 4360371.5 & 484918.7 & 1899.82 \\
\hline 650 & LB & 0.0 & pin & 4360400.9 & 484893.5 & 1901.43 \\
\hline 650 & RB & 25.3 & pin & 4360376.3 & 484882.0 & 1902.05 \\
\hline 679 & LB & 0.0 & $\operatorname{pin}^{3}$ & 4360413.8 & 484872.5 & 1901.46 \\
\hline 679 & $\mathrm{RB}$ & 24.7 & pin & 4360396.2 & 484855.6 & 1902.85 \\
\hline 698 & LB & 0.0 & nail & 4360423.7 & 484850.2 & 1903.14 \\
\hline 698 & RB & 20.8 & pin & 4360404.6 & 484844.1 & 1903.49 \\
\hline 715 & LB & 0.0 & pin & 4360433.8 & 484829.5 & 1904.91 \\
\hline 715 & $\mathrm{RB}$ & 21.8 & pin & 4360410.8 & 484830.5 & 1904.68 \\
\hline 735 & LB & 0.0 & nail & 4360433.5 & 484810.4 & 1905.67 \\
\hline 735 & $\mathrm{RB}$ & 29.4 & nail & 4360404.6 & 484811.2 & 1904.64 \\
\hline 755 & LB & 0.0 & pin & 4360438.3 & 484796.1 & 1906.35 \\
\hline 755 & RB & 34.0 & pin & 4360405.2 & 484787.8 & 1905.82 \\
\hline 785 & LB & 0.0 & $\operatorname{pin}^{4}$ & 4360440.9 & 484768.1 & 1907.25 \\
\hline 785 & $\mathrm{RB}$ & 27.0 & nail & 4360416.1 & 484757.6 & 1907.30 \\
\hline 815 & LB & 0.0 & pin & 4360448.5 & 484739.5 & 1908.20 \\
\hline 815 & RB & 25.5 & pin & 4360424.3 & 484732.2 & 1909.09 \\
\hline 845 & LB & 0.0 & nail & 4360460.7 & 484713.1 & 1909.74 \\
\hline 845 & RB & 27.5 & pin & 4360436.6 & 484700.1 & 1909.52 \\
\hline 875 & LB & 0.0 & $\operatorname{pin}^{5}$ & 4360468.6 & 484682.2 & 1910.05 \\
\hline 875 & $\mathrm{RB}$ & 18.5 & pin & 4360451.2 & 484675.9 & 1910.50 \\
\hline 905 & LB & 0.0 & pin & 4360478.1 & 484649.2 & 1910.55 \\
\hline 905 & RB & 24.9 & pin & 4360453.5 & 484653.3 & 1911.94 \\
\hline 935 & LB & 0.0 & nail & 4360479.6 & 484620.8 & 1912.78 \\
\hline 935 & RB & 24.3 & pin & 4360455.3 & 484620.7 & 1912.61 \\
\hline 965 & LB & 0.0 & pin & 4360476.6 & 484588.8 & 1914.63 \\
\hline 965 & $\mathrm{RB}$ & 12.0 & pin & 4360454.2 & 484593.3 & 1913.55 \\
\hline 985 & LB & 0.0 & nail & 4360474.1 & 484570.5 & 1914.60 \\
\hline 985 & RB & 18.9 & nail & 4360455.3 & 484571.6 & 1914.11 \\
\hline 1006 & LB & 0.0 & pin & 4360472.3 & 484550.9 & 1914.67 \\
\hline 1006 & RB & 18.9 & pin & 4360453.8 & 484549.4 & 1914.92 \\
\hline 1025 & LB & 0.0 & pin & 4360473.3 & 484532.3 & 1916.06 \\
\hline 1025 & RB & 17.3 & nail & 4360456.4 & 484530.0 & 1915.72 \\
\hline 1055 & LB & 0.0 & pin & 4360478.3 & 484506.9 & 1916.29 \\
\hline 1055 & RB & 18.1 & pin & 4360462.5 & 484498.0 & 1916.04 \\
\hline 1083 & LB & 0.0 & nail & 4360483.4 & 484475.8 & 1918.10 \\
\hline 1083 & $\mathrm{RB}$ & 14.6 & nail & 4360469.1 & 484474.2 & 1917.60 \\
\hline
\end{tabular}




\section{Appendix 7. (Continued) UTM coordinates for cross-section end points in Spring Creek}

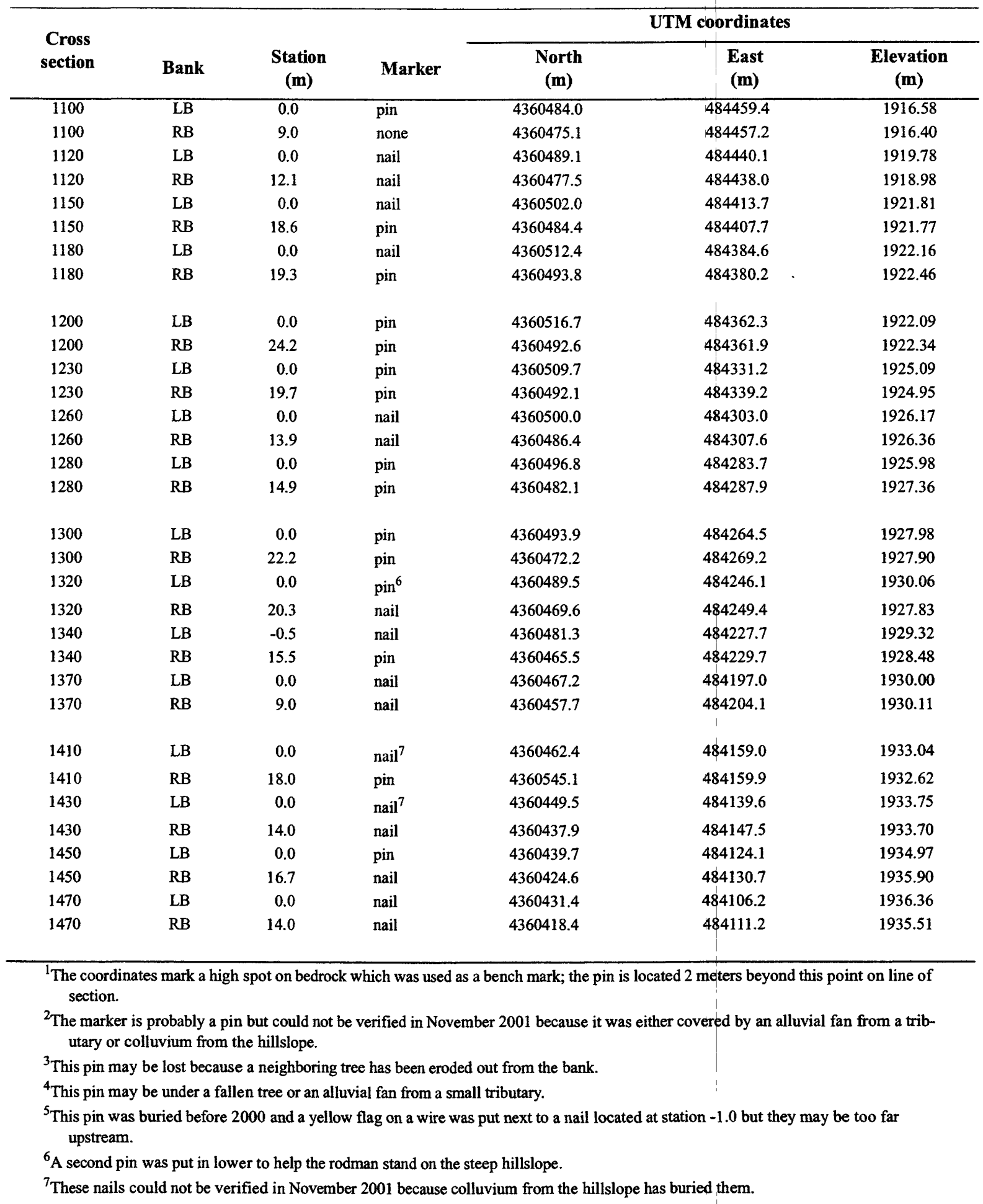




\section{Appendix 8. Format of cross-section and transect files for Spring Creek}

[Data are on the accompanying CD in directory SpringCreek. The directory SpringCreek has 19 subdirectories listed in the Survey column below. The data file names have the form $s N N T M M M M$.raw, or $s N N x M M M M$.raw, where s stands for Spring Creek, $N N$ is the survey number, $t$ stands for transect, $x$ stands for cross section, $M M M$ or $M M M M$ is the transect or cross section number. A small ' $\mathrm{m}$ ' means minus and ' $p$ ' represents the decimal point; surveys 060296 and 080296 have UTM coordinates and elevations above sea level with no prefix $s N N$; the other surveys have arbitrary coordinates--see Appendices 4-7]

\begin{tabular}{|c|c|c|c|c|c|c|c|}
\hline \multirow{2}{*}{ Survey } & \multirow{2}{*}{ Dates } & \multicolumn{5}{|c|}{ Column in the data file } & \multirow[b]{2}{*}{ Comments } \\
\hline & & & 2 & 3 & 4 & 5 & \\
\hline \multicolumn{8}{|c|}{ Spring Creek 1996} \\
\hline s060296 & 02 June & East $(\mathrm{m})$ & North (m) & $\begin{array}{l}\text { Elevation } \\
\text { (m) }\end{array}$ & blank & blank & $\begin{array}{l}\text { Measurements were made from the right- } \\
\text { bank to the left bank using aerial photo- } \\
\text { grammetry and are in UTM coordinates. } \\
\text { File extension is .txt not .raw. }\end{array}$ \\
\hline s080296 & 02 August & East (m) & North (m) & $\begin{array}{l}\text { Elevation } \\
\quad(\mathrm{m})\end{array}$ & blank & blank & $\begin{array}{l}\text { Measurements were made from the right- } \\
\text { bank to the left bank using aerial photo- } \\
\text { grammetry and are in UTM coordinates. } \\
\text { File extension is .txt not .raw. }\end{array}$ \\
\hline \multicolumn{8}{|c|}{ Spring Creek 1997} \\
\hline s01 & $\begin{array}{l}29 \text { May } \\
\text { to } \\
11 \text { June }\end{array}$ & $\begin{array}{c}\text { Shot } \\
\text { number }\end{array}$ & North (m) & East (m) & $\begin{array}{l}\text { Elevation } \\
\text { (m) }\end{array}$ & $\begin{array}{l}\text { ID number or } \\
\text { distance from } \\
\text { left bank or } \\
\text { blank }\end{array}$ & $\begin{array}{l}\text { Transects are comma and space delimited } \\
\text { and cross sections are space delimited. }\end{array}$ \\
\hline $\mathrm{s} 02$ & $\begin{array}{l}22 \text { July } \\
\text { to } \\
28 \text { July }\end{array}$ & $\begin{array}{l}\text { Shot } \\
\text { number }\end{array}$ & North (m) & East (m) & $\begin{array}{l}\text { Elevation } \\
\text { (m) }\end{array}$ & $\begin{array}{l}\text { ID number or } \\
\text { distance from } \\
\text { left bank }\end{array}$ & $\begin{array}{l}\text { Files are comma delimited and some } \\
\text { points from survey } 01 \text { were added at the } \\
\text { beginning or end of the file. }\end{array}$ \\
\hline s03 & $\begin{array}{l}3 \text { August } \\
\text { to } \\
8 \text { August }\end{array}$ & $\begin{array}{c}\text { Shot } \\
\text { number }\end{array}$ & North (m) & East (m) & $\begin{array}{l}\text { Elevation } \\
\quad(\mathrm{m})\end{array}$ & $\begin{array}{l}\text { ID number or } \\
\text { distance from } \\
\text { left bank }\end{array}$ & $\begin{array}{l}\text { Files are comma delimited and some } \\
\text { points from previous surveys were } \\
\text { added at the beginning or end of the file. }\end{array}$ \\
\hline s04a & $\begin{array}{l}\text { Estimate for } \\
31 \text { August }\end{array}$ & $\begin{array}{l}\text { Shot } \\
\text { number }\end{array}$ & North (m) & East (m) & $\begin{array}{l}\text { Elevation } \\
\text { (m) }\end{array}$ & $\begin{array}{l}\text { ID number or } \\
\text { distance from } \\
\text { left bank }\end{array}$ & $\begin{array}{l}\text { File extension is .est and comma delimited. } \\
\text { Used survey } 04 \text { data and essentially con- } \\
\text { nected terraces on left and right banks. } \\
\text { Shot points with number } 000 \text { are esti- } \\
\text { mated values. }\end{array}$ \\
\hline s04 & $\begin{array}{l}27 \text { Septem- } \\
\text { ber } \\
\text { to } \\
6 \text { October }\end{array}$ & $\begin{array}{l}\text { Shot } \\
\text { number }\end{array}$ & North (m) & East (m) & $\begin{array}{l}\text { Elevation } \\
\text { (m) }\end{array}$ & $\begin{array}{l}\text { ID number or } \\
\text { distance from } \\
\text { left bank }\end{array}$ & $\begin{array}{l}\text { Data are comma delimited. Some points } \\
\text { from previous surveys were added at the } \\
\text { beginning or end of the file. }\end{array}$ \\
\hline \multicolumn{8}{|c|}{ Spring Creek 1998} \\
\hline s05 & $\begin{array}{l}28 \text { April } \\
\text { to } \\
3 \text { May }\end{array}$ & $\begin{array}{c}\text { Shot } \\
\text { number }\end{array}$ & North (m) & East (m) & $\begin{array}{l}\text { Elevation } \\
\quad(\mathrm{m})\end{array}$ & $\begin{array}{l}\text { ID number or } \\
\text { distance from } \\
\text { left bank }\end{array}$ & $\begin{array}{l}\text { Data are comma delimited. Some points } \\
\text { from previous surveys were added at the } \\
\text { beginning or end of the file. }\end{array}$ \\
\hline s06 & $\begin{array}{l}19 \text { May } \\
\text { to } \\
21 \text { May }\end{array}$ & $\begin{array}{l}\text { Shot } \\
\text { number }\end{array}$ & North $(m)$ & East (m) & $\begin{array}{l}\text { Elevation } \\
\text { (m) }\end{array}$ & $\begin{array}{l}\text { ID number or } \\
\text { distance from } \\
\text { left bank }\end{array}$ & $\begin{array}{l}\text { Data are comma delimited. Some points } \\
\text { from previous surveys were added at the } \\
\text { beginning or end of the file. }\end{array}$ \\
\hline
\end{tabular}




\section{Appendix 8. (Continued) Format of cross-section and transect files for Spring Creek}

\begin{tabular}{|c|c|c|c|c|c|c|c|}
\hline \multirow{2}{*}{ Survey } & \multirow{2}{*}{ Dates } & \multicolumn{5}{|c|}{ Column in the data file } & \multirow[b]{2}{*}{ Comments } \\
\hline & & & 2 & 3 & 4 & 5 & \\
\hline s07 & $\begin{array}{l}1 \text { July } \\
\text { to } \\
2 \text { July }\end{array}$ & $\begin{array}{c}\text { Shot } \\
\text { number }\end{array}$ & North $(\mathrm{m})$ & East (m) & $\begin{array}{c}\text { Elevation } \\
(\mathrm{m})\end{array}$ & $\begin{array}{l}\text { ID number or } \\
\text { distance from } \\
\text { left bank }\end{array}$ & $\begin{array}{l}\text { Data are comma delimited. Did not survey } \\
\text { transect }-020 \text { nor cross section }-2.7 \text { and } \\
\text { assumed no change. Transects and cross } \\
\text { sections from } 0030 \text { to } 0640 \text { were resur- } \\
\text { veyed. }\end{array}$ \\
\hline s07 & $\begin{array}{l}1 \text { July } \\
\text { to } \\
2 \text { July }\end{array}$ & $\begin{array}{l}\text { Measure- } \\
\text { ment } \\
\text { number }\end{array}$ & $\begin{array}{l}\text { Distance } \\
\text { from left } \\
\text { bank }(\mathrm{m})\end{array}$ & $\begin{array}{l}\text { nothing just } \\
\text { zeros }\end{array}$ & $\begin{array}{l}\text { Elevation } \\
\text { (m) }\end{array}$ & ID number & $\begin{array}{l}\text { Data are space delimited. Transects and } \\
\text { cross sections from } 0679 \text { to } 1470 \text { were } \\
\text { resurveyed using automatic level, metric } \\
\text { tape, and surveying rod. }\end{array}$ \\
\hline $\begin{array}{c}\text { s08 } \\
.\end{array}$ & $\begin{array}{l}16 \text { July } \\
\text { to } \\
17 \text { July }\end{array}$ & $\begin{array}{l}\text { Measure- } \\
\text { ment } \\
\text { number }\end{array}$ & $\begin{array}{l}\text { Distance } \\
\text { from left } \\
\text { bank (m) }\end{array}$ & $\begin{array}{l}\text { nothing just } \\
\text { zeros }\end{array}$ & $\begin{array}{l}\text { Elevation } \\
\text { (m) }\end{array}$ & ID number & Data are space delimited. \\
\hline s09 & $\begin{array}{l}5 \text { August } \\
\text { to } \\
6 \text { August }\end{array}$ & $\begin{array}{l}\text { Measure- } \\
\text { ment } \\
\text { number }\end{array}$ & $\begin{array}{l}\text { Distance } \\
\text { from left } \\
\text { bank (m) }\end{array}$ & $\begin{array}{l}\text { nothing just } \\
\text { zeros }\end{array}$ & $\begin{array}{l}\text { Elevation } \\
\text { (m) }\end{array}$ & ID number & Data are space delimited. \\
\hline s10 & $\begin{array}{l}12 \text { October } \\
\text { to } \\
14 \text { October }\end{array}$ & $\begin{array}{l}\text { Measure- } \\
\text { ment } \\
\text { number }\end{array}$ & $\begin{array}{l}\text { Distance } \\
\text { from left } \\
\text { bank (m) }\end{array}$ & $\begin{array}{l}\text { nothing just } \\
\text { zeros }\end{array}$ & $\begin{array}{l}\text { Elevation } \\
\text { (m) }\end{array}$ & ID number & Data are space delimited. \\
\hline \multicolumn{8}{|c|}{ Spring Creek 1999} \\
\hline s11 & $\begin{array}{l}20 \mathrm{March} \\
\text { to } \\
21 \mathrm{March}\end{array}$ & $\begin{array}{l}\text { Measure- } \\
\text { ment } \\
\text { number }\end{array}$ & $\begin{array}{l}\text { Distance } \\
\text { from left } \\
\text { bank (m) }\end{array}$ & $\begin{array}{l}\text { nothing just } \\
\text { zeros }\end{array}$ & $\begin{array}{l}\text { Elevation } \\
\text { (m) }\end{array}$ & ID number & Data are space delimited. \\
\hline s12 & $\begin{array}{l}16 \text { July } \\
\text { to } \\
17 \text { July }\end{array}$ & $\begin{array}{l}\text { Measure- } \\
\text { ment } \\
\text { number }\end{array}$ & $\begin{array}{l}\text { Distance } \\
\text { from left } \\
\text { bank (m) }\end{array}$ & $\begin{array}{l}\text { nothing just } \\
\text { zeros }\end{array}$ & $\begin{array}{l}\text { Elevation } \\
(\mathrm{m})\end{array}$ & ID number & Data are space delimited. \\
\hline s13 & $\begin{array}{l}31 \text { July } \\
\text { to } \\
1 \text { August }\end{array}$ & $\begin{array}{l}\text { Measure- } \\
\text { ment } \\
\text { number }\end{array}$ & $\begin{array}{l}\text { Distance } \\
\text { from left } \\
\text { bank }(m)\end{array}$ & $\begin{array}{l}\text { nothing just } \\
\text { zeros }\end{array}$ & $\begin{array}{l}\text { Elevation } \\
(\mathrm{m})\end{array}$ & ID number & Data are space delimited. \\
\hline s14 & $\begin{array}{l}8 \text { November } \\
\text { to } \\
9 \text { November }\end{array}$ & $\begin{array}{l}\text { Measure- } \\
\text { ment } \\
\text { number }\end{array}$ & $\begin{array}{l}\text { Distance } \\
\text { from left } \\
\text { bank (m) }\end{array}$ & $\begin{array}{l}\text { nothing just } \\
\text { zeros }\end{array}$ & $\begin{array}{l}\text { Elevation } \\
\text { (m) }\end{array}$ & ID number & Data are space delimited. \\
\hline \multicolumn{8}{|c|}{ Spring Creek 2000} \\
\hline s15 & $\begin{array}{l}13 \text { May } \\
\text { to } \\
14 \text { May }\end{array}$ & $\begin{array}{l}\text { Measure- } \\
\text { ment } \\
\text { number }\end{array}$ & $\begin{array}{l}\text { Distance } \\
\text { from left } \\
\text { bank (m) }\end{array}$ & $\begin{array}{l}\text { nothing just } \\
\text { zeros }\end{array}$ & $\begin{array}{l}\text { Elevation } \\
(\mathrm{m})\end{array}$ & ID number & Data are space delimited. \\
\hline s16 & 21 October & $\begin{array}{l}\text { Measure- } \\
\text { ment } \\
\text { number }\end{array}$ & $\begin{array}{l}\text { Distance } \\
\text { from left } \\
\text { bank (m) }\end{array}$ & $\begin{array}{l}\text { nothing just } \\
\text { zeros }\end{array}$ & $\begin{array}{l}\text { Elevation } \\
\text { (m) }\end{array}$ & ID number & Data are space delimited. \\
\hline
\end{tabular}




\section{Appendix 9. Format of cross-section and transect files for Buffalo Creek}

[Data are on the accompanying CD in directory BuffaloCreek. The data file names have the form $B c N N t M M M$.raw, BcNNxMMM.raw, BNNtMMM.raw, or $B N N x M M M$.raw, where $B$ or $B c$ stands for Buffalo Creek, $N N$ is the survey number, $t$ stands for transect, $x$ stands for cross section, and $M M M$ or $M M M M$ is the transect or cross section number; surveys have arbitrary coordinates--see Appendices 4-7]

\begin{tabular}{|c|c|c|c|c|c|c|c|}
\hline \multirow{2}{*}{ Survey } & \multirow{2}{*}{ Dates } & \multicolumn{5}{|c|}{ Column in the data file } & \multirow[b]{2}{*}{ Comments } \\
\hline & & 1 & 2 & 3 & 4 & 5 & \\
\hline \multicolumn{8}{|c|}{ Buffalo Creek 1997} \\
\hline $\mathrm{Bc} 01$ & $\begin{array}{l}12 \text { June } \\
\text { to } \\
16 \text { June }\end{array}$ & $\begin{array}{c}\text { Shot } \\
\text { number }\end{array}$ & North (m) & East (m) & $\begin{array}{l}\text { Elevation } \\
\text { (m) }\end{array}$ & $\begin{array}{l}\text { ID number } \\
\text { Some cross sec- } \\
\text { tions list distance } \\
\text { from left bank }\end{array}$ & $\begin{array}{l}\text { Transects are comma and space delim- } \\
\text { ited and cross sections are space } \\
\text { delimited. }\end{array}$ \\
\hline $\mathrm{Bc} 02$ & $\begin{array}{l}18 \text { July } \\
\text { to } \\
21 \text { July }\end{array}$ & $\begin{array}{c}\text { Shot } \\
\text { number }\end{array}$ & North (m) & East (m) & $\begin{array}{l}\text { Elevation } \\
\text { (m) }\end{array}$ & $\begin{array}{l}\text { ID number } \\
\text { Some cross sec- } \\
\text { tions list distance } \\
\text { from left bank }\end{array}$ & Data are comma delimited. \\
\hline $\mathrm{Bc} 03$ & $\begin{array}{l}10 \text { August } \\
\text { to } \\
11 \text { August }\end{array}$ & $\begin{array}{c}\text { Shot } \\
\text { number }\end{array}$ & North (m) & East (m) & $\begin{array}{l}\text { Elevation } \\
\text { (m) }\end{array}$ & $\begin{array}{c}\text { ID number } \\
\text { Cross sections list } \\
\text { distance from left } \\
\text { bank }\end{array}$ & $\begin{array}{l}\text { Transects are comma and space delim- } \\
\text { ited and cross sections are space } \\
\text { delimited. }\end{array}$ \\
\hline \multicolumn{8}{|c|}{ Buffalo Creek 1998} \\
\hline B04 & $\begin{array}{l}7 \text { May } \\
\text { to } \\
9 \text { May }\end{array}$ & $\begin{array}{c}\text { Shot } \\
\text { number }\end{array}$ & North (m) & East (m) & $\begin{array}{l}\text { Elevation } \\
\text { (m) }\end{array}$ & $\begin{array}{c}\text { D number } \\
\text { Cross sections list } \\
\text { distance from left } \\
\text { bank }\end{array}$ & Data are comma delimited. \\
\hline B05 & 21 July & $\begin{array}{l}\text { Measure- } \\
\text { ment } \\
\text { number }\end{array}$ & $\begin{array}{l}\text { Distance } \\
\text { from left } \\
\text { bank }(\mathrm{m})\end{array}$ & $\begin{array}{l}\text { nothing just } \\
\text { zeros }\end{array}$ & $\begin{array}{l}\text { Elevation } \\
\text { (m) }\end{array}$ & ID number & Data are space delimited. \\
\hline B06 & 7 August & $\begin{array}{l}\text { Measure- } \\
\text { ment } \\
\text { number }\end{array}$ & $\begin{array}{l}\text { Distance } \\
\text { from left } \\
\text { bank }(\mathrm{m})\end{array}$ & $\begin{array}{l}\text { nothing just } \\
\text { zeros }\end{array}$ & $\begin{array}{l}\text { Elevation } \\
\text { (m) }\end{array}$ & ID number & Data are space delimited. \\
\hline B07 & 17 October & $\begin{array}{l}\text { Measure- } \\
\text { ment } \\
\text { number }\end{array}$ & $\begin{array}{l}\text { Distance } \\
\text { from left } \\
\text { bank (m) }\end{array}$ & $\begin{array}{l}\text { nothing just } \\
\text { zeros }\end{array}$ & $\begin{array}{l}\text { Elevation } \\
\text { (m) }\end{array}$ & ID number & Data are space delimited. \\
\hline \multicolumn{8}{|c|}{ Buffalo Creek 2000} \\
\hline B08 & 4 June & $\begin{array}{c}\text { Measure- } \\
\text { ment } \\
\text { number }\end{array}$ & $\begin{array}{l}\text { Distance } \\
\text { from left } \\
\text { bank (m) }\end{array}$ & $\begin{array}{l}\text { nothing just } \\
\text { zeros }\end{array}$ & $\begin{array}{l}\text { Elevation } \\
\text { (m) }\end{array}$ & ID number & Data are space delimited. \\
\hline
\end{tabular}




\section{Appendix 10. Information for erosion and deposition files for Spring and Buffalo Creeks}

[Data are on accompanying CD in directory ErosionDeposition. The data files SCedarea.ext and Bcedarea.ext have 3 columns, which are sometimes delimited by commas and sometimes delimited by spaces; .ext is the file extension. In the data file column 1 is the cross section or transect ID number; column 2 is the Net erosion in $\mathrm{m}^{2}$; and column 3 is the Net deposition in $\mathrm{m}^{2}$. Files for Spring Creek have a prefix SC and those for Buffalo Creek have a prefix $\mathrm{Bc} ; \mathrm{m}^{2}$, square meter]

\begin{tabular}{|c|c|c|}
\hline File extension & Spring Creek & Buffalo Creek \\
\hline .000 & 02 June $1996-02$ August 1996 & None \\
\hline $.00 \mathrm{a}$ & 02 August 1996 - 05 June 1997 & None \\
\hline .001 & 05 June 1997 -- 25 July 1997 & 14 June $1997-19$ July 1997 \\
\hline .002 & 25 July $1997-6$ August 1997 & 19 July $1997-11$ August 1997 \\
\hline .003 & 6 August 1997 - 31 August 1997 & 11 August 1997 -- 08 May 1998 \\
\hline .004 & 31 August 1997 -- 02 October 1997 & 08 May 1998 - 21 July 1998 \\
\hline .005 & 2 October 1997 - 01 May 1998 & 21 July $1998-07$ August 1998 \\
\hline .006 & 01 May 1998 - 20 May 1998 & 07 August $1998-17$ October 1998 \\
\hline .007 & 20 May 1998 - 02 July 1998 & 17 October $1998-04$ June 2000 \\
\hline .008 & 02 July $1998-17$ July 1998 & None \\
\hline .009 & 17 July 1998 -- 06 August 1998 & None \\
\hline .010 & 06 August $1998-13$ October 1998 & None \\
\hline .011 & 13 October 1998 - 21 March 1999 & None \\
\hline .012 & 21 March 1999 .- 17 July 1999 & None \\
\hline .013 & 17 July 1999 -- 01 August 1999 & None \\
\hline .014 & 01 August 1999 - 08 November 1999 & None \\
\hline .015 & 08 November 1999 -- 14 May 2000 & None \\
\hline .016 & 14 May $2000-21$ October 2000 & None \\
\hline
\end{tabular}




\section{Appendix 11. Formats for erosion data collected in watersheds W960 and W1165}

[m, meter; $\mathrm{cm}$, centimeter; $\mathrm{m}^{2}$, square meter]

Data are on the accompanying CD in directory Watersheds.

The data are in two data files w960.dat and w1165.dat:

Column $1=$ observation number

Column $2=$ stream order

Column $3=$ stream number

Column $4=$ distance from mouth $(\mathrm{m})$

Column $5=$ cumulative stream length $(\mathrm{m})$

Column $6=$ top width of channel $(\mathrm{cm})$

Column $7=$ bottom width of channel $(\mathrm{cm})$

Column $8=$ depth of channel $(\mathrm{cm})$

Column $9=$ rise of channel slope (m)

Column $10=$ run of channel slope $(\mathrm{m})$

Column 11 = rise of side slope on left bank (m)

Column 12 = run of side slope on left or right bank (m)

Column $13=$ roughness height $(\mathrm{cm}), 999=$ not determined

Column $14=$ erosion $(-1)$ or deposition (1)

The summary data are in the ASCII files w960e.dat and w1165e.dat:

Column 1 = observation number

Column 2 = cumulative stream length above the measurement $(\mathrm{m})$

Column $3=$ area of net erosion $\left(\mathrm{m}^{2}\right)$

Column $4=$ slope of the drainage channel over a distance of 1.8 meter

Column $5=$ cumulative drainage area upstream from measurement section $\left(\mathrm{m}^{2}\right)$ 


\section{Appendix 12. Interpolated particle-size distribution for the bed material in Spring Creek}

[See Table 6.1 for the measured values; fitted values were calculated from a cubic spline program provided by R. Stallard; phi equals $-\log _{2}$ (diameter in millimeters); mm, millimeter]

\begin{tabular}{|c|c|c|c|c|}
\hline \multicolumn{2}{|c|}{ Particle size } & \multicolumn{2}{|c|}{ Fitted values } & \multirow{2}{*}{$\frac{\text { Measured value }}{\text { Percent finer }}$} \\
\hline (phi) & $(\mathbf{m m})$ & $\begin{array}{l}\text { Percent per phi } \\
\text { interval }\end{array}$ & Percent finer & \\
\hline 5.0 & 0.032 & 0.67 & 0.76 & - \\
\hline 4.75 & 0.037 & 0.76 & 0.94 & -- \\
\hline 4.50 & 0.044 & 0.86 & 1.15 & -- \\
\hline 4.25 & 0.053 & 0.96 & 1.37 & - \\
\hline 4.00 & 0.062 & 1.07 & 1.63 & 1.6 \\
\hline 3.75 & 0.074 & 1.17 & 1.91 & - \\
\hline 3.50 & 0.088 & 1.22 & 2.21 & - \\
\hline 3.25 & 0.105 & 1.24 & 2.52 & - \\
\hline 3.00 & 0.125 & 1.22 & 2.83 & 2.9 \\
\hline 2.75 & 0.149 & 1.22 & 3.13 & -- \\
\hline 2.50 & 0.177 & 1.29 & 3.44 & - \\
\hline 2.25 & 0.210 & 1.43 & 3.78 & - \\
\hline 2.00 & 0.250 & 1.64 & 4.17 & 4.1 \\
\hline 1.75 & 0.297 & 1.88 & 4.61 & -- \\
\hline 1.50 & 0.354 & 2.09 & 5.10 & -- \\
\hline 1.25 & 0.420 & 2.27 & 5.65 & -- \\
\hline 1.00 & 0.500 & 2.43 & 6.24 & 6.4 \\
\hline 0.75 & 0.595 & 2.69 & 6.87 & -- \\
\hline 0.50 & 0.707 & 3.16 & 7.60 & - \\
\hline 0.25 & 0.841 & 3.84 & 8.47 & - \\
\hline 0.00 & 1.00 & 4.75 & 9.54 & 9.7 \\
\hline-0.25 & 1.19 & 5.99 & 10.9 & - \\
\hline-0.50 & 1.41 & 7.69 & 12.6 & - \\
\hline-0.75 & 1.68 & 9.85 & 14.8 & - \\
\hline-1.00 & 2.00 & 12.5 & 17.5 & 17.2 \\
\hline-1.25 & 2.38 & 15.3 & 21.0 & - \\
\hline-1.50 & 2.83 & 18.1 & 25.2 & - \\
\hline-1.75 & 3.36 & 20.8 & 30.0 & - \\
\hline-2.00 & 4.00 & 23.5 & 35.6 & 34.4 \\
\hline-2.25 & 4.76 & 23.6 & 41.7 & - \\
\hline-2.50 & 5.66 & 25.3 & 48.1 & - \\
\hline-2.75 & 6.73 & 23.5 & 54.3 & -- \\
\hline-3.00 & 8.00 & 19.9 & 59.7 & 61.3 \\
\hline-3.25 & 9.51 & 15.6 & 64.1 & - \\
\hline-3.50 & 11.3 & 11.9 & 67.6 & - \\
\hline-3.75 & 13.4 & 8.72 & 70.1 & -- \\
\hline-4.00 & 16.00 & 6.08 & 72.0 & 72.2 \\
\hline-4.25 & 19.0 & 4.14 & 73.2 & -- \\
\hline-4.50 & 22.6 & 3.08 & 74.1 & -- \\
\hline-4.75 & 26.9 & 2.88 & 74.8 & - \\
\hline-5.00 & 32.0 & 3.55 & 75.6 & 75.1 \\
\hline-6.00 & 64.0 & 8.01 & 81.5 & 81.7 \\
\hline-7.00 & 128. & 9.40 & 91.0 & 92.0 \\
\hline-8.00 & 256 & 4.09 & 97.6 & - \\
\hline-9.00 & 512 & 8.99 & 99.9 & 100.0 \\
\hline
\end{tabular}




\section{Appendix 13. Distances from station 15 in Strontia Springs Reservoir along the center line of the reservoir}

[Station 15 is at the beginning of the reservoir and the station numbers decrease in the downstream direction; whole integer numbered stations have bench marks along the shoreline and the distance between these whole integer numbered stations was divided into ten sections and listed as a decimal value in the table below; $12 / 13$ was a station between station 12 and station 13 and also has a bench mark; m, meter]

\begin{tabular}{|c|c|c|c|}
\hline Station & $\begin{array}{l}\text { Distance } \\
\text { (m) }\end{array}$ & Station & $\begin{array}{c}\text { Distance } \\
\text { (m) }\end{array}$ \\
\hline & & 11.5 & 815 \\
\hline 15 & 0 & 11.4 & 834 \\
\hline 14 & 100 & 11.3 & 853 \\
\hline 13.9 & 130 & 11.2 & 872 \\
\hline 13.8 & 159 & 11.1 & 891 \\
\hline 13.7 & 188 & 11 & 910 \\
\hline 13.6 & 218 & 10.9 & 923 \\
\hline 13.5 & 248 & 10.8 & 937 \\
\hline 13.4 & 277 & 10.7 & 950 \\
\hline 13.3 & 306 & 10.6 & 964 \\
\hline 13.2 & 336 & 10.5 & 977 \\
\hline 13.1 & 366 & 10.4 & 990 \\
\hline 13 & 396 & 10.3 & 1004 \\
\hline $12 / 13.9$ & 412 & 10.2 & 1017 \\
\hline $12 / 13.8$ & 429 & 10.1 & 1031 \\
\hline $12 / 13.7$ & 445 & 10 & 1044 \\
\hline $12 / 13.6$ & 462 & 9.9 & 1060 \\
\hline $12 / 13.5$ & 478 & 9.8 & 1077 \\
\hline $12 / 13.4$ & 494 & 9.7 & 1093 \\
\hline $12 / 13.3$ & 511 & 9.6 & 1110 \\
\hline $12 / 13.2$ & 527 & 9.5 & 1126 \\
\hline 12/13.1 & 544 & 9.4 & 1142 \\
\hline $12 / 13$ & 560 & 9.3 & 1159 \\
\hline 12.9 & 576 & 9.2 & 1175 \\
\hline 12.8 & 592 & 9.1 & 1192 \\
\hline 12.7 & 608 & 9 & 1208 \\
\hline 12.6 & 624 & 8.8 & 1264 \\
\hline 12.5 & 640 & 8.6 & 1320 \\
\hline 12.4 & 656 & 8.4 & 1376 \\
\hline 12.3 & 672 & 8.2 & 1432 \\
\hline 12.2 & 688 & 8.0 & 1488 \\
\hline 12.1 & 704 & 7.8 & 1515 \\
\hline 12 & 720 & 7.6 & 1543 \\
\hline 11.9 & 739 & 7.4 & 1570 \\
\hline 11.8 & 758 & 7.2 & 1598 \\
\hline 11.7 & 777 & 7 & 1625 \\
\hline 11.6 & 796 & & \\
\hline
\end{tabular}




\section{Appendix 14. Longitudinal bathymetric surveys of Strontia Springs Reservoir}

[Data are on the accompanying CD in directory StrontiaSprings. Station, Denver Water Department's bench marks located on each side of the reservoir; File is the name of the data file on the CD. In the data files, the format is column 1 equals the distance from station 15 in meters, column 2 equals the depth in feet, column 3 equals the distance from station 15 in feet, and column 4 equals the elevation above sea level in feet.]

\begin{tabular}{|c|c|c|c|c|c|}
\hline $\begin{array}{l}\text { Survey } \\
\text { number }\end{array}$ & Date & $\begin{array}{l}\text { Water level } \\
\text { (feet) }\end{array}$ & $\begin{array}{c}\text { Station } \\
\text { Beginning to } \\
\text { Ending }\end{array}$ & File & Comments \\
\hline \multicolumn{6}{|c|}{1993} \\
\hline 0 & 1993 & unknown & not applicable & S1993.dat ${ }^{a}$ & $\begin{array}{l}\text { Pre-fire elevations at } 9 \text { locations along the } \\
\text { center line of the reservoir. }\end{array}$ \\
\hline \multicolumn{6}{|c|}{1996} \\
\hline 1 & 13 September & 5995.6 & 7 to 13.3 & S13sep96.dat & \\
\hline 11 & 23 September & not measured & 12 to 13 & STopgrvl.dat ${ }^{\mathbf{a}}$ & Elevations at the top of the gravel layer. \\
\hline 12 & 23 September & not measured & 12 to 13 & STopblck.dat ${ }^{a}$ & Elevations at the top of the black layer. \\
\hline 13 & 23 September & not measured & 12 to 13 & SBotblck.dat ${ }^{\mathrm{a}}$ & Elevations at the bottom of the black layer. \\
\hline 2 & 2 October & 5996.0 & 7 to 14.5 & S02oct96.dat & \\
\hline \multicolumn{6}{|c|}{1997} \\
\hline 3 & 27 June & 5996.84 & 7 to 14 & S27jun97.dat & \\
\hline 4 & 13 August & 5994.9 & 10 to 14 & S13aug97.dat & \\
\hline 5 & 12 September & 5992.6 & 7 to 13.9 & S12sep97.dat & \\
\hline \multicolumn{6}{|c|}{1998} \\
\hline 6 & 22 May & 5993.1 & 8 to 14 & S22may 98 .dat & \\
\hline 7 & 15 July & 5987.8 & 8 to 12.2 & S15jul98.dat & $\begin{array}{l}\text { Water was too shallow to reach upstream of } \\
\text { station } 12.2 \text {. }\end{array}$ \\
\hline 8 & 3 August & 5991.75 & 7 to $12 / 13$ & S03aug98.dat & Water depth was measured with an oar. \\
\hline 9 & 23 October & 5998.76 & 7 to 14 & S23oct98.dat & \\
\hline \multicolumn{6}{|c|}{1999} \\
\hline 10 & 4 June & 6003.7 & 7 to 14 & S04jun99.dat $t^{a}$ & Estimated depths were from stations 7 to 9. \\
\hline
\end{tabular}

\footnotetext{
${ }^{a}$ Column 2 equals the elevation above sea level in feet and colums 3 and 4 are blank.
} 